\title{
Archeological Impact Evaluations and Surveys in the Texas Department of Transportation's Atlanta, Dallas, Fort Worth, Paris, and Waco Districts, 1998-2000
}

Ross C. Fields

Prewitt and Associates, Inc.

E. Frances Gadus

Prewitt and Associates, Inc.

Karl W. Kibler

Cross Timbers Geoarcheological Services

Lee C. Nordt

Prewitt and Associates, Inc.

Follow this and additional works at: https://scholarworks.sfasu.edu/ita

Part of the American Material Culture Commons, Archaeological Anthropology Commons, Environmental Studies Commons, Other American Studies Commons, Other Arts and Humanities Commons, Other History of Art, Architecture, and Archaeology Commons, and the United States History Commons

Tell us how this article helped you.

This Article is brought to you for free and open access by the Center for Regional Heritage Research at SFA ScholarWorks. It has been accepted for inclusion in Index of Texas Archaeology: Open Access Gray Literature from the Lone Star State by an authorized editor of SFA ScholarWorks. For more information, please contact cdsscholarworks@sfasu.edu. 


\section{Archeological Impact Evaluations and Surveys in the Texas Department of}

Transportation's Atlanta, Dallas, Fort Worth, Paris, and Waco Districts, 1998-2000

\section{Creative Commons License}

\section{(c) (i) $\Theta($}

This work is licensed under a Creative Commons Attribution-NonCommercial-No Derivative Works 4.0 International License. 


\title{
ARCHEOLOGICAL IMPACT EVALUATIONS AND SURVEYS IN THE TEXAS DEPARTMENT OF TRANSPORTATION'S ATLANTA, DALLAS, FORT WORTH, PARIS, AND WACO DISTRICTS, 1998-2000
}

\author{
by \\ Ross C. Fields \\ E. Frances Gadus \\ Karl W. Kibler \\ and \\ Lee C. Nordt \\ with Contributions by \\ Amy M. Holmes \\ J ennifer K. McWilliams \\ J ohn W. Arnn III \\ Paul Maslyk \\ and \\ Gemma Mehalchick
}

Principal Investigator: Ross C. Fields

REPORTS OF INVESTIGATIONS, NUMBER 128

Prewitt and Associates, Inc. Cultural Resources Services Austin, Texas

\author{
ARCHEOLOGY STUDIES PROGRAM, REPORT 24 \\ Texas Department of Transportation \\ Environmental Affairs Division
}

August 2000

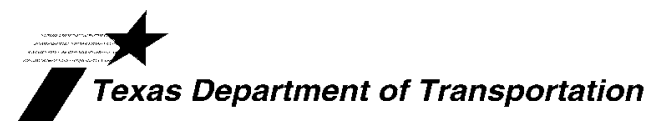

ISBN 1-930788-02-9 


\section{CONTRACT DATA}

Preparation of this document was accomplished under Order No. 8-0271, Req. No. 601298-80990, with the Texas Department of Transportation, Environmental Affairs Division, 125 E. 11th Street, Austin, Texas 78701-2483. 
TABLE OF CONTE NTS

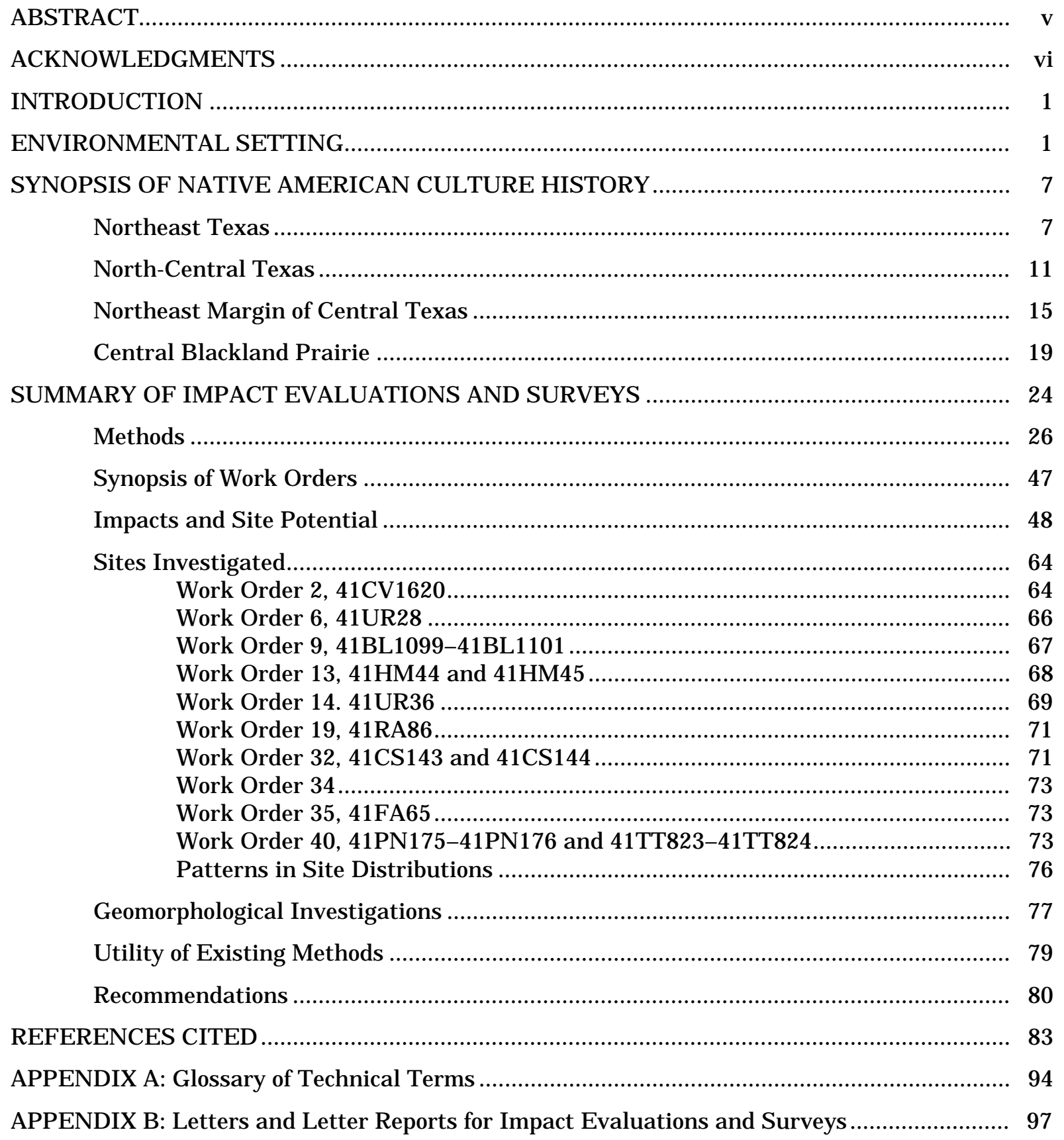




\section{LIST OF FIGURES}

1. Locations of the Atlanta, Dallas, Fort Worth, Paris, and Waco Districts in relation

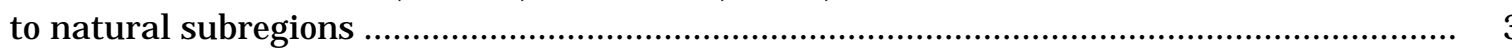

2. Major drainages in the Atlanta, Dallas, Fort Worth, Paris, and Waco Districts ................. 5

3. Map of the study area showing the locations of all I mpact Evaluations and Surveys .......... 25

4. Schematic cross section of a bridge approach showing common disturbance factors ............ 49

5. Alluvial stratigraphic cross section of the Brazos River valley along Loop 340

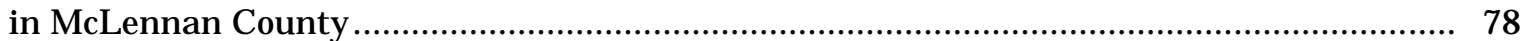

\section{LIST OF TABLES}

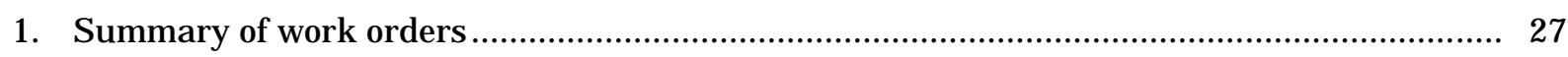

2. Summary of existing impacts by work order ................................................................. 50

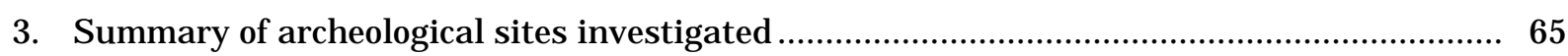

4. Radiocarbon dates obtained from Brazos River alluvium in Work Order $8 \ldots \ldots \ldots \ldots \ldots \ldots \ldots \ldots . . . . . . . . . . . .77$ 


\begin{abstract}
This document constitutes the final report of work done by Prewitt and Associates, Inc. (PAI), under a contract from the Texas Department of Transportation (TxDOT) to provide archeological services in five TxDOT districts-Atlanta, Dallas, Fort Worth, Paris, and Waco-in northeast, north-central, and central Texas. Under this contract, PAI completed Impact Evaluations and Surveys to assist TxDOT in meeting the requirements of their Memorandum of Understanding with the Texas Historical Commission and a Programmatic Agreement between the Advisory Council on Historic Preservation, the Federal Highway Administration, the Texas Historical Commission, and TxDOT. The contract began on 31 August 1998 and concluded on 31 August 2000. During these two years, 41 work orders were completed.

The 41 work orders consisted of 119 Impact Evaluations, 21 Surveys, 3 Surveys with Geoarcheological Evaluation, 1 work order for a quality control meeting with TxDOT, and 1 work order to produce this report. Combined, these work orders entailed efforts at 151 bridge or relief structure replacements, 14 projects involving primarily road widening or realignment (most with bridge replacements as well), and 1 project consisting of construction of an exit ramp. During completion of these work orders, 16 newly discovered or previously recorded archeological sites and 1 possible site were investigated.

Fourteen of the Impact Evaluations resulted in a recommendation that an archeological survey be completed prior to construction. In 69 additional I mpact Evaluations for which specific constructions were not available, survey was recommended if areas outside the existing right of way, or below the zone of disturbance within the existing right of way, will be disturbed substantially. The remaining 36 I mpact Evaluations resulted in a recommendation that no survey be required based on the extent of disturbance and the limited potential for sites with good integrity. Three of the Surveys investigated sites that were recommended for testing to assess eligibility for listing in the National Register of Historic Places and designation as State Archeological Landmarks. On two other surveys, it was recommended that charcoal recovered be radiocarbon dated to aid in making the decision about whether testing is needed. The other 19 Surveys either did not find any archeological sites or investigated sites that could be assessed as ineligible for National Register listing and State Archeological Landmark designation using the survey data.
\end{abstract}




\section{ACKNOWLEDGMENTS}

A number of people contributed to the successful completion of this project. Lain Ellis managed the contract for the Archeol ogy Studies Program, Environmental Affairs Division, Texas Department of Transportation, with the oversight of Nancy Kenmotsu and the assistance of Steve Ahr, Pat McLoughlin, and Barbara Hickman. At Prewitt and Associates, Ross Fields served as Principal Investigator, while Doug Boyd was the Quality Control Officer. E. Frances Gadus, J ohn Arnn, J enny McWilliams, Paul Maslyk, Gemma Mehalchick, Karl Kibler, and Amy Holmes served as Project Archeologists, with Mr. Kibler and Ms. Holmes also filling the position of Project Geoarcheologist. These individuals performed most of the fieldwork and were responsible for writing most of the reports on individual work orders included as Appendix B; the site descriptions included in the body of the report are extracted from the work order reports. Mr. Kibler also prepared the Environmental Setting section of the report and one of the culture history summaries (Northeast Margin of Central Texas), while Ms. Gadus wrote or contributed to two of the other summaries (Northeast Texas and North-Central Texas). Lee Nordt was the Project Geoarcheol ogist on one work order involving trenching in the Brazos River valley at Waco; he authored part of the original letter report as well as the revised discussion of the results of his investigations that appears in the body. Mr. Fields wrote the remainder of the report. Support at Prewitt and Associates was provided by Karen Gardner (laboratory supervision, photograph cataloging, and curation), Brian Wootan and Sandra Hannum (production of graphics), Audra Pineda (report editing), and Melissa Keenan (report production). 


\section{INTRODUCTION}

This document constitutes the final report of work done by Prewitt and Associates, Inc. (PAI), under a contract (P.O. No. 8-0271; Req. No. 60129-8-80990-B) from the Texas Department of Transportation (TXDOT) to provide archeological services in five TxDOT districtsAtlanta, Dallas, Fort Worth, Paris, and Wacoin northeast, north-central, and central Texas. The contract began on 31 August 1998 and concluded on 31 August 2000. During these two years, 41 work orders were completed, with the final one being issued on 25 April 2000 so that the draft version of this report could be submitted in J une 2000, allowing time for review and revisions prior to the end of the contract.

Under this contract, PAI completed Impact Evaluations and Surveys to assist TXDOT in meeting the requirements of their Memorandum of Understanding with the Texas Historical Commission and a Programmatic Agreement between the Advisory Council on Historic Preservation, the Federal Highway Administration, the Texas Historical Commission, and TXDOT. Impact Evaluations are defined by TxDOT as "on-site inspection ... documenting existing impacts or other conditions which may preclude the presence of intact archeological deposits within the project area for a proposed Transportation Activity." Thus, Impact Evaluations are an initial step to determine whether survey of a particular area is warranted, given the anticipated impacts of the project, the existing level of disturbance, and the likelihood of archeo-logical deposits in good context. Surveys are defined by TXDOT as "archeological field work . . .of a proposed Transportation Activity to locate archeological remains, if any, includeing onfoot examination of the surface, shovel testing, and subsurface trenching by mechanical means where appropriate." As described below, PAl completed 41 work orders involving 119 Impact Evaluations and 24 Surveys. Three of the surveys included geoarcheol ogical evaluations, while 21 did not. Most of these projects focused on the replacement of specific bridges and relief structures on federal and state highways, farm-to-market roads, and county roads. Other kinds of Transportation
Activities included road widening projects and the construction of new bypasses; many of these included bridge replacements within their overall larger scopes.

The body of this report consists of three major sections. Following this introduction is a brief characterization of the environmental setting of the five TxDOT districts. Four brief synopses of Native American culture histories are presented next. One deals with northeast Texas and encompasses the Atlanta District and the eastern part of the Paris District; one covers north-central Texas and is relevant to the western Paris District and the northern parts of the Dallas and Fort Worth Districts; one deals with the northeast margin of central Texas and applies to the western part of the Waco District and the southern edge of the F ort Worth District; and one is for the central Blackland Prairie and covers the southern part of the Dallas District and the eastern part of the Waco District. The third section summarizes the work done under this contract: the methods employed in the Impact Evaluations and Surveys are discussed and their effectiveness is evaluated; tables are presented listing the Impact Evaluations/Surveys and their topographic and geologic settings, soils, land use, vegetation, and presence/absence of archeological sites; the sites investigated are described; the existing impacts that affect the potential of project areas to contain sites with sufficient integrity to be eligible for National Register of Historic Places listing or State Archeological Landmark designation are listed and discussed; and overall recommendations concerning the I mpact Evaluation/Survey process are provided. The body of the report is followed by a references cited section and two appendixes. Appendix $A$ is a glossary of technical terms, while Appendix B (on CD-ROM) contains the letters and reports submitted to TXDOT concerning all I mpact Evaluations and Surveys done under the contract.

\section{ENVIRONMENTAL SETTING}

The Atlanta, Dallas, Fort Worth, Paris, and Waco Districts cover a 42-county area in northeastern and north-central Texas. Almost all of the five-district area lies within the Gulf Coastal Plain physiographic province, its 
inland (western) edge hinging on the Central Lowland and Great Plains provinces which make up a small portion of the study area (Fenneman 1931, 1938). The intersection of these three physiographic provinces has witnessed an interesting and dynamic geologic history (see Hayward 1988a, 1988b; Hayward et al. 1996; Spearing 1991). The western half of the area straddles a deep-seated fracture zone and site of past orogenic events that separates the stable continental interior to the west from the subsiding Gulf basin to the east and southeast. The rise of the Ouachita Mountains along this zone in the Paleozoic resulted in the deposition of clastic sediments on a broad shelf along the margin of the Permian Basin located southwest of the five-district area. These sediments formed the Pennsylvanian and Permian rock units of the western part of the Fort Worth District. These sandstone and mudstone units dip and become progressively younger toward the basin. Later, during the Cretaceous as the Gulf of Mexico formed, clastic sediments and carbonates were deposited over the worn-down Ouachita Mountains and along the broad marginal shelf of the Gulf basin. The Lower Cretaceous sandstones, mudstones, limestones, and marls found throughout parts of the Dallas, Fort Worth, Paris, and Waco Districts represent cycles of marine transgression and regression throughout the period. By Upper Cretaceous times, infilling of the Gulf basin and shoreline progradation predominated as evidenced by Upper Cretaceous sandstones and mudstones throughout much of the Paris District and the eastern parts of the Dallas, Fort Worth, and Waco Districts. Marine regression and shoreline progradation continued during the Tertiary period and is represented by Eocene sandstones and mudstones of the Atlanta District and the eastern parts of the Paris, Dallas, and Waco Districts.

The different rock units have a major influence on the topography, flora, and hydrology across the five-district area. Eight natural subregions lie within the study area, due in part to these lithological variations (Figure 1). These eight subregions are the Mixed Pine-Hardwood Forest of the Piney Woods region, the Oak Woodlands, Eastern and Western Cross Timbers of the Oak Woods and Prairies region, the Blackland Prairie and Grand Prairie of the Blackland Prairies region, the Mesquite Plains of the Rolling Plains region, and the Lampasas Cut Plain of the Edwards Plateau region (LBJ School of Public Affairs 1978). The Mixed PineHardwood subregion is limited to the Atlanta District and covers the most of that district. The Oak Woodlands subregion encompasses the northern margin of the Atlanta District, the eastern and northern margins of the Paris District, the southeastern corner of the Dallas District, and the easternmost part of the Waco District. The Eastern Cross Timbers covers portions of the Dallas, Fort Worth, Paris, and Waco Districts, while the Western Cross Timbers make up part of the Fort Worth and Waco Districts. The Blackland Prairie subregion covers the central portion of the five-district area, covering parts of the Dallas, Fort Worth, Paris, and Waco Districts. The Grand Prairie subregion constitutes parts of the Dallas, Fort Worth, and Waco Districts. The Mesquite Plains subregion is limited to the western portion of the Fort Worth District, while the Lampasas Cut Plain is limited to the southwestern portion of the Waco District.

The modern plant communities vary from subregion to subregion. The Mixed PineHardwood Forest consists of deciduous forests (forests having greater than 60 percent canopy) of loblolly pine, shortleaf pine, overcup oak, swamp chestnut oak, willow oak, water oak, sweetgum, and sweetbay (Diamond et al. 1987). Deciduous woodlands (woodlands having 26-60 percent canopy) of bluejack oak and pine and swamp communities of baldcypress, buttonbush, and water elm are also a part of the Mixed Pine-Hardwood Forest. The Blackland Prairie consists of tall grasslands, primarily little bluestem and Indiangrass, with riparian deciduous forests of sugarberry and elm (Diamond et al. 1987). The flora of the Eastern Cross Timbers consists of deciduous forests of post oak and black hickory and woodlands of post oak and blackjack oak. The Grand Prairie is a mixed-grass prairie dominated by little bluestem and containing isolated live oak mottes and juniper and mesquite savannas (Hayward et al. 1996). The Western Cross-Timbers consists primarily of deciduous woodlands of post oaks and blackjack 


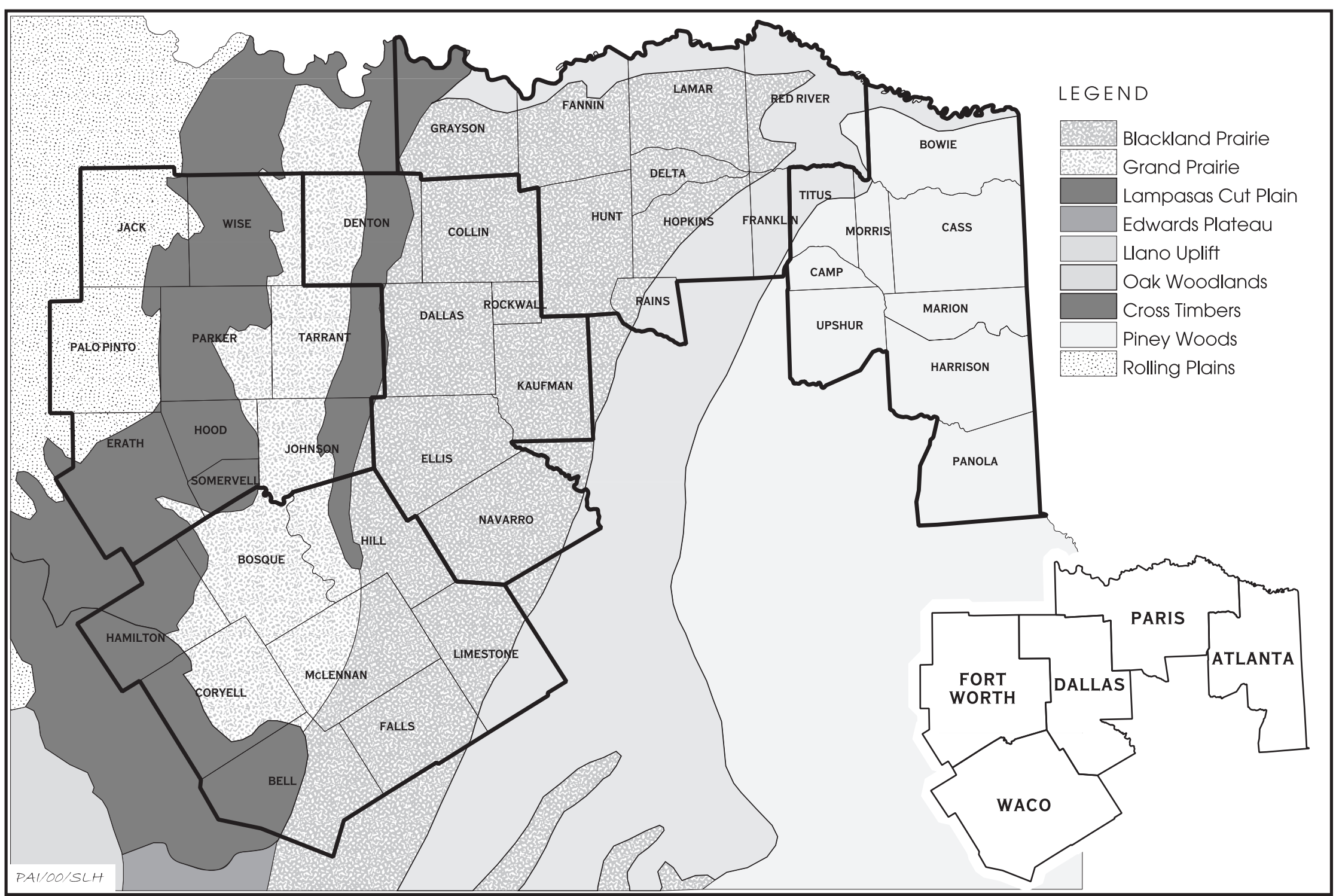

Figure 1. Locations of the Atlanta, Dallas, Fort Worth, Paris, and Waco Districts in relation to natural subregions. 
oaks (Diamond et al. 1987). The Mesquite Plains along the western margin of the Fort Worth District consists of evergreen and deciduous shrub lands of oneseed juniper, redberry juniper, sand sage, and Mohr's shin oak, with an understory of little bluestem and sideoats grama grasses. Plant communities of the Lampasas Cut Plain include deciduous wood-lands of Texas oak and deciduous riparian forests of sugarberry and elm.

The major drainages within the fivedistrict area are the Red River, the Sulphur River, Big Cypress Bayou, the Sabine River, the Trinity River, and the Brazos River (Figure 2). The Red River flows east along the northern edge of the Paris and Atlanta Districts. Upstream from the Lamar-Red River County line, the Red River floodplain is ca. $4 \mathrm{~km}$ in width, while downstream at Bowie County the floodplain averages $10 \mathrm{~km}$ in width. Holocene-age alluvium underlies the floodplain, which for the most part is flanked by extensive Pleistocene terraces both south and north of the river (McGowen et al. 1967; Shel by et al. 1979). Holocene alluvium also is mapped along several south-bank tributaries of the Red River, including Pine Creek, Little Pine Creek, Pecan Bayou, Bois d'Arc Creek, and Choctaw Creek.

The Sulphur River flows east through Red River, Franklin, Titus, Morris, Bowie, and Cass Counties in the Paris and Atlanta Districts. Its major tributaries or branches, the North Sulphur, Middle Sulphur, South Sulphur, and White Oak Bayou, head in Delta, Fannin, Hopkins, Hunt, and Lamar Counties to the west. The Sulphur River has a ca. 2-kmwide floodplain with Holocene fill that along some segments is flanked by remnants of Pleistocene terraces (Shel by et al. 1979). All of its branches or major tributaries contain Holocene floodplains that exceed $1 \mathrm{~km}$ in width and are bordered sporadically by Pleistocene terraces. Holocene alluvium also is mapped along the many smaller tributaries throughout the basin.

Big Cypress Bayou flows east and southeast through Franklin, Titus, Camp, Morris, Upshur, Marion, and Harrison Counties. It is joined by its largest tributary, Little Cypress Creek, in Harrison County east of J efferson. Upstream from the confluence, floodplains with Holocene alluvium average ca. $2 \mathrm{~km}$ in width, while downstream the floodplain of Big Cypress Bayou is ca. $3 \mathrm{~km}$ wide (Pieper et al. 1975). Only small, widely scattered Pleistocene terrace deposits are mapped for this basin, except along Black Bayou, Frazier Creek, and Jims Bayou, which drain southeastern Cass County and northeastern Marion County and empty into Big Cypress Bayou east of the Texas-Louisiana line. Tributaries with relatively wide (up to ca. $1 \mathrm{~km}$ ) floodplains (and thus extensive Holocene alluvium) consist of the following: Greasy Creek, Hart Creek, Tankersley Creek, and Boggy Creek, which drain into Big Cypress Bayou; Caney Creek, Lilly Creek, and Kelsey Creek, which flow into Little Cypress Creek; and Black Cypress Bayou, Frazier Creek, and J ims Bayou, which flow into Big Cypress Bayou downstream from J efferson. Many smaller tributaries have less-extensive mapped Holocene alluvium.

The Sabine River flows east along the southern boundary of Rains County (Paris District) leaving the five-district area and then reentering it at Upshur and Harrison Counties (Atlanta District). Here, it continues east-southeast along the southern boundary of Harrison County before turning southeast-ward across the middle of Panola County. Prior to entering the Atlanta District, the Holocene floodplain of the Sabine River averages 2-3 km in width (Pieper et al. 1975). Downstream from this point, Holocene alluvial deposits ca. $6 \mathrm{~km}$ wide are mapped, as are extensive Pleistocene terrace deposits at the edges of the valley. Extensive Holocene alluvial surfaces also are mapped along Lake Fork Creek, a large tributary of the Sabine that flows in a southeasterly direction across the Paris District and enters the Sabine River outside the five-district area. Major north-bank tributaries, with floodplains $1 \mathrm{~km}$ or more wide, include Potters Creek, Eightmile Creek, Quapaw Creek, Socagee Creek, and Mill Creek, while major south-bank tributaries are Martin Creek, Irons Bayou, and Murvaul Bayou. A variety of minor tributaries have less-extensive mapped Holocene alluvium.

The Trinity River and its major branches flow through the Fort Worth and Dallas 


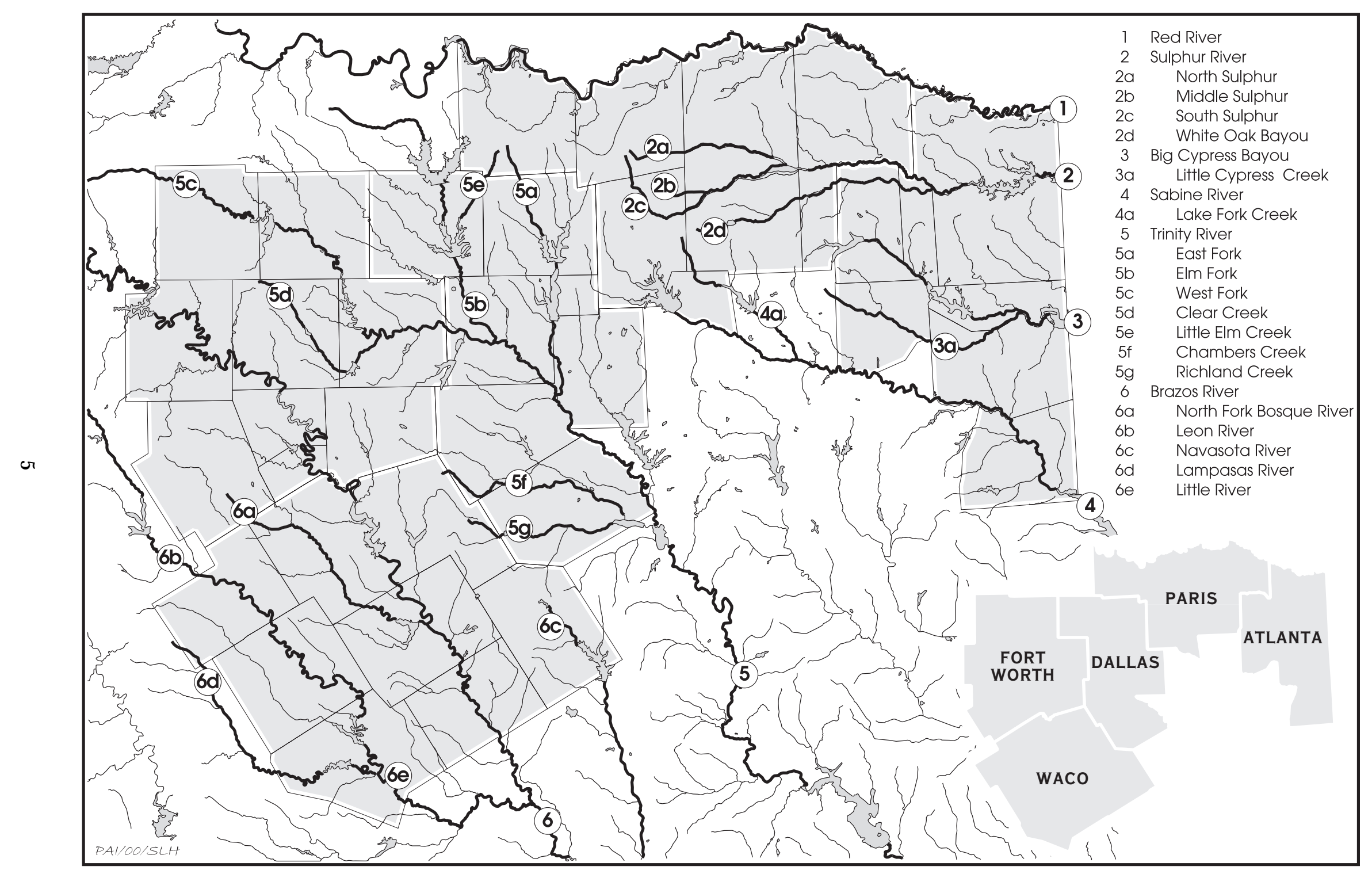

Figure 2. Major drainages in the Atlanta, Dallas, Fort Worth, Paris, and Waco Districts. 
Districts. The various branches of the Trinity River (East Fork, Elm Fork, West Fork, Clear Creek, and Little EIm Creek) come together in and around the Dallas-F ort Worth metroplex. Below this point, the Trinity River flows southeast and the Holocene floodplain is broad and vast (up to $9 \mathrm{~km}$ wide) and bordered by extensive Pleistocene terraces (McGowen et al. 1972). Two large tributaries, Chambers and Richland Creeks, enter the Trinity along this stretch. Both creeks flow in an easterly direction and have Holocene floodplains ca. 3$5 \mathrm{~km}$ wide.

The branches of the Trinity River all contain Holocene alluvium below floodplains that are up to $1 \mathrm{~km}$ wide. One of the larger branches, the West Fork Trinity River, flows southeast across J ack and Wise Counties in the F ort Worth District, where its floodplain is narrow $(<1 \mathrm{~km})$ and no Pleistocene terraces are mapped (Hentz and Brown 1987; McGowen et al. 1967). However, as it enters Tarrant County it flows south and then abruptly turns eastward flowing through the City of Fort Worth; it is along this stretch that extensive Holocene and Pleistocene alluvial surfaces are mapped (McGowen et al. 1972). Several tributaries of the West Fork Trinity River flow southeast across Wise County (Big Sandy Creek and Denton Creek) and northeast across J ohnson and Tarrant Counties (Clear Fork Trinity River and Village Creek). Holocene floodplains averaging $1 \mathrm{~km}$ in width are mapped along these tributaries, as well as remnants of Pleistocene terraces (McGowen et al. 1967, 1972).

The Brazos River flows southeast through the Fort Worth (Palo Pinto, Parker, Hood, Somervell, and J ohnson Counties) and Waco (Bosque, Hill, McLennan, and Fall Counties) Districts. Upstream from Waco, the Holocene floodplain of the Brazos River is very narrow (if not absent), and at Lake Whitney and Lake Granbury it is below the surface of the flood pools (Brown et al. 1972; McGowen et al. 1972; Proctor et al. 1970). Pleistocene terraces are extensive along this stretch, however. At and downstream from Waco as the Brazos enters the Gulf Coastal Plain, the Holocene floodplain is ca. 6- $7 \mathrm{~km}$ wide and bordered by segmented Pleistocene terraces. Several large tributaries flow through the study area: the
North Fork Bosque River, the Leon River, the Navasota River, the Lampasas River, and the Little River. Several smaller Brazos River tributaries with mapped Holocene alluvium include Big Creek, the Little Brazos River, Pond Creek, Tehuacana Creek, and Aquilla Creek (Proctor et al. 1970).

The North F ork Bosque River flows southward across Erath County. Narrow $(<1 \mathrm{~km})$ Holocene floodplains are mapped along this stretch (Brown et al. 1972). The North Bosque River then flows east and southeast through Hamilton, Bosque, and MCLennan Counties. Its Holocene floodplain is ca. $1 \mathrm{~km}$ wide and bordered by a few small Pleistocene terrace segments or the bedrock valley wall (Proctor et al. 1970). Tributaries of the North Bosque River with mapped Holocene alluvium include Meridian Creek, Neils Creek, Hog Creek, and the Middle Bosque River. The Leon River flows southeast across Hamilton, Coryell, and Bell Counties (Kier et al. 1976; Proctor et al. 1970). The Holocene floodplain is ca. $1 \mathrm{~km}$ wide and bounded by Pleistocene terrace segments or the bedrock valley wall. Tributaries of the Leon River with mapped alluvium include Cowhouse Creek and Coryell Creek (Proctor et al. 1970). The Navasota River flows southeast across Limestone County. On average, its Holocene floodplain is $1.5 \mathrm{~km}$ wide; it is flanked by few Pleistocene terraces (Proctor et al. 1970). Larger tributaries of the Navasota River with mapped Holocene alluvium include Christmas Creek and Steele Creek.

The Lampasas River flows southeast through Hamilton County, skirts outside the western margin of the Waco District, and reenters the district as it flows east and northeast across Bell County where it merges with the Leon River to form the Little River. The Lampasas River has a relatively narrow Holocene floodplain averaging less than $1 \mathrm{~km}$ in width (Kier et al. 1976; Proctor et al. 1981). Small Pleistocene terrace remnants flank the floodplain along some segments of the river. The Little River, forming at the confluence of the Leon and Lampasas Rivers, flows southeast across Bell County. The Holocene floodplain of the Little River is ca. $3 \mathrm{~km}$ wide and bordered by large Pleistocene terraces along most of its course (Proctor et al. 1981). 


\section{SYNOPSIS OF NATIVE AMERICAN CULTURE HISTORY}

\section{Northeast Texas}

This synopsis covers the northeastern part of the state, encompassing the Atlanta District and the eastern part of the Paris District. Most of this area is in the Piney Woods, although the northern Oak Woodlands and the northeastern part of the Blackland Prairie are included as well. Major drainages are the Red and Sabine Rivers on the north and south, with the Sulphur River and Cypress Bayou basins in between. Compared to some other parts of the state, the archeology of this region is relatively well known, at least for the late part of prehistory. This can be traced directly to the long history of investigations focusing on Caddo sites, as thoroughly documented by Guy (1990) and Davis (1970), among others.

Occupation of northeast Texas area during the Paleoindian period (10,000-6000 B.C.) is demonstrated by the frequent, if not abundant, occurrence of projectile points such as Clovis, Dalton, San Patrice, and Scottsbluff and other distinctive tools such as Albany scrapers, Red River knives, and Dalton adzes (Story 1990: 177) at sites such as J ohn Pearce in Louisiana just east of Harrison County (Webb et al. 1971), J ake Martin in Upshur County (Davis and Davis 1960), and Forrest Murphey in Marion County (Story 1990:180). Often, Paleoindian materials occur as single artifacts or are from mixed contexts. Still, from the few more-extensive deposits such as at those sites named above, some general observations about lifeways for this period can be made.

Story (1990:177; Story et al. 1990:425426) observes that Paleoindian sites typically contain limited amounts of refuse and that the assemblages are marked by the following: high selectivity in tool types with carefully fashioned bifaces and unifaces being especially common; extensive curation, refurbishing, and recycling of tools; frequent use of high-quality, often nonlocal, lithic materials; a near-absence of tools and facilities indicative of plant processing; and broad distributions of particular artifact styles. Based on these characteristics, she speculates that Paleoindian adaptations in northeast Texas involved high residential mobility and large territories, short-lived occupations by small groups at individual sites, low population densities and hence little competition for resources, a generalized subsistence strategy focusing on hunting rather than plant collecting, and fluidity in group composition and movement as a means of avoiding or resolving economic or social problems.

The remains of occupations by Archaic groups (6000-200 B.c.), especially late Archaic peoples, are abundant in northeastern Texas, although a complete sequence of artifact styles and assemblages has yet to be developed. According to Story (1990:213; Story et al. 1990:426), Archaic-period sites are characterized by greater quantities of refuse, the appearance of tools and facilities suggestive of plant processing, tools that were less well made and more frequently of local materials than those of the Paleoindian period, functionally diverse tool assemblages containing relatively large proportions of expedient tools, limited tool curation and recycling compared to the Paleoindian period, reasonably distinctive regional artifact styles, and the appearance of cemeteries. From these observations, she goes on to suggest that Archaic-period adaptations involved the seasonal foraging and hunting of a wide variety of resources, with plant foods attaining greater importance; exploitation patterns that were more intensive and more focused geographically than were patterns of Paleoindian land use; betterdefined and less-extensive group territories; decreased residential mobility and hence less direct access to nonlocal materials; and more involvement in trade relationships as a means of solving economic and social problems. While Archaic artifacts are common in the region, excavated sites that are predominantly Archaic in age or where Archaic components can be isolated from later components are rare. Some of the excavated Archaic sites in the region include J ake Martin in Upshur County (Davis and Davis 1960), Yarbrough in Van Zandt County (J ohnson 1962), Finley Fan in Hopkins County (Gadus et al. 1992), Tankersley Creek and 41TT372 in Titus County (Barnhart et al. 1997; Young 1981), and 41BW422 in Bowie County (Tucker 1994). 
The Woodland period (200 B.C.-A.D. 800) covers the ca. 1,000-year span preceding the appearance of the Caddoan culture and is pivotal to understanding this important cultural development in northeastern Texas and adjacent parts of Arkansas, Louisiana, and Oklahoma. The origins of the Caddoan culture have been debated for many years, but Story's (1990) synthesis of the archeology of the region suggests that speakers of Caddoan languages occupied the area before the development of a recognizable Caddoan archeological tradition, that the adoption of maize agriculture did not trigger the Caddoan florescence, and that early Caddoan culture was influenced by but did not develop out of Lower Mississippi Valley cultures. Thus, according to Story (1990:293), “. . . there can be little doubt that the emergence of a distinctive southern Caddoan archeological tradition was basically an in situ development within resident communities of Caddoan speakers." This is supported by Perttula's (1990) view of the coevolution of cultural systems and cultivated plants in the region. In brief, Perttula (1990:Part I, 70-97) suggests that there was substantial continuity in subsistence strategies from the late Archaic period through the early half of the Caddoan period, including increased use of domesticated cucurbits, bottle gourds, and native oily seeded and starchy seeded plants such as sumpweed, Chenopodium, maygrass, knotweed, and sunflower. While tropical cultigens were introduced during this time and were present across the Caddoan region by ca. A.D. 1000, the development of true agroecological systems, and hence the adoption of vastly different subsistence strategies, did not occur until later, probably after A.D. 1200 (Perttula 1990:Part I, 97). While the idea of local origins for the Caddoan culture is likely to hold up under further scrutiny, there are limited data from excavated, discrete Woodland sites in the northeast Texas region as a whole with which to evaluate this hypothesis.

Woodland sites in southwestern Arkansas are associated with the Fourche Maline culture (Schambach 1982a:132-197). Fourche Maline is represented archeologically by Gary dart points; flower pot-shaped ceramic vessels with bone, grit, or grog temper; and Lower
Mississippi Valley ceramics which have been found in association with numerous village middens and mound sites along the Great Bend of the Red River. Fourche Maline sites such as Crenshaw, a multicomponent village and mound complex located in southwestern Arkansas, also produced intriguing evidence of early mortuary rituals. Four large Fourche Maline cemeteries are known from the site, while Mound $F$ was found to contain a large circular mass grave at its base (Schambach 1982b:150-158). The occurrence of ceremonial interments and mound construction points to the beginnings of a hierarchical social system that is indicative of how the Fourche Maline culture foreshadows the Caddoan florescence.

In the lower Sulphur River valley, Woodland occupations are represented by materials from localities such as the Snipes site at Wright Patman Lake (J elks 1961:41-54; Story 1990:304) and 41CS151 in Cass County (Cliff and Hunt 1995:144-146; Cliff et al. 1996:131161). Both of these sites produced Gary dart points; however, the Snipes site also produced ceramics suggesting that it may represent a slightly later occupation. Ceramics from the Snipes site consist of Williams Plain and some Lower Mississippi Valley types such as Coles Creek Incised and possibly Marksville I ncised. Burials from the site were generally extended with some grave offerings. These details caused Story to suggest that the Snipes site was more closely related to the Woodland manifestations in southwestern Arkansas than to those of the more westerly parts of northeast Texas (Story 1990:303-305). This is supported by the abundant and relatively well-sampled Woodland record at Cooper Lake in the upper Sulphur River basin of Delta and Hopkins Counties. There, sites with middens indicating intensive occupation and yielding numerous Gary and Kent dart points are common. These sites lack ceramics, however, and most of the limited number of burials dating to this period are cremations lacking grave offerings (Fields et al. 1997:86-88; Perttula 1999:385).

In the upper Sabine River and upper Cypress Bayou basins, the Woodland period generally is poorly understood because isolable components have proven elusive. While noting several problems with the data, Story (1990: 
309-314) offers the following conclusions based largely on the published data from Lake Fork Reservoir in Rains and Wood Counties (Bruseth and Perttula 1981; Perttula and Skiles 1988) and Thurmond's (1981, 1985, 1990) synthesis of the archeology of the Cypress basin: (1) most of the Woodland occupations appear to date to the late part of the period; (2) settlement density was low compared to the Caddoan period; (3) a variety of sites were used, including short-term camps and more-intensively occupied small settlements represented by the earliest cultural middens in the area; (4) the limited macrobotanical evidence suggests that hardwood nuts, and probably less likely maize, contributed to the diet; and (5) there are no constructed mounds or elaborate burials reflecting the development of complex ritual or social systems. One important excavated site dating to this interval, the Resch site (Webb et al. 1969), is located on Potters Creek in the Sabine River basin in southern Harrison County, and Webb (1982) reports on a number of sites in northwestern Louisiana, including the excavated McKinney Mound site in Caddo Parish, that apparently date to this time period. The presence of small burial mounds at some of Webb's (1982) Bellevue focus sites implies greater cultural complexity for the Native American peoples who lived in the Red River valley of northwestern Louisiana than for the contemporary groups in Texas, although most of the Bellevue sites have seen only limited work and thus present interpretive difficulties.

There is ample evidence for intensive use of the Great Bend of the Red River valley, and the valleys of the Sulphur River, Cypress Bayou, and Sabine River to the south, during the Caddoan period (A.D. 800-1700). It has long been recognized that the Great Bend area, extending from above Texarkana to bel ow Shreveport, was a focal point of Caddoan development, as this area contains a number of early Caddoan mound sites with elaborate burials pointing to hierarchical social systems (Schambach 1982b:7). The general picture is one of sedentary agricultural groups inhabiting small farmsteads dispersed around these vacant ceremonial mound centers (Schambach and Early 1982). The burials from the T. M.
Sanders site in Lamar County (Krieger 1946), the structural mound and other evidence at the A. C. Mackin site in Lamar County (Mallouf 1976), and the mound and burial evidence at the Dan Holdeman site in Red River County (Perino 1995) indicate at least moderate social complexity for early Caddoan groups well west of the Great Bend.

J udging from the historic accounts and the archeological evidence, it is clear that the Great Bend region also was occupied intensively during the latter half of the Caddoan period. Settlement systems consisting of dispersed farmsteads and vacant ceremonial centers seem to have prevailed throughout the period in at least parts of the region (Kelley 1994; Schambach 1982b:7-10), and the occurrence of mound centers and elaborate shaft burials with rich grave offerings indicates the continuation of structured, hierarchical social systems. This manifestation of Caddoan culture in the Great Bend area has two labels, the Texarkana phase and the Belcher phase. The Texarkana phase was defined from information gathered from the Hatchel mound by WPA excavations and by the excavation of the Mitchell and Moores cemetery sites (Davis 1970:50-51; Krieger 1946). These sites are along the Red River in northern Bowie County. The Belcher phase covers the lower half of the Great Bend, having been defined based on work at the Belcher mound located north of Shreveport, Louisiana (Webb 1959). The two phases are marked by distinctive ceramic assemblages which suggest differing social and political affinities. Based on the occurrence of middle to late Caddoan mounds or elaborate burials at sites such as Sam Kaufman-Bob Williams-Roden, Wright Plantation, Dan Holdeman, and Rowland Clark in and just north of Red River County (Bruseth et al. 1991, 1992; Perino 1981, 1983, 1994, 1995; Skinner et al. 1969), it is clear that Caddoan complexes at least partly comparable to those of the Great Bend area extended well westward.

It is difficult to determine how the lower part of the Sulphur River basin was used during the early Caddoan period because so little work has been done there. While five possible mound sites were documented in surveys at Wright Patman Lake (Malone and 
Briggs 1970:82, 84; Stephenson 1950a:6-8), little is known about them, including their ages, and the only two excavated Caddoan sites date to the latter part of the period (J elks 1961). Nonetheless, the proximity of this part of the basin to the Great Bend of the Red River and the knowledge that mound sites (e.g., the Haley site) occur along the Red near the mouth of the Sulphur certainly lead to the expectation that the area was used with some intensity during this interval. Moving upstream, middens implying intensive use during the early to middle parts of the Caddoan period have been documented at 41CS150, 41CS151, and 41CS155/41CS156 in Cass County (Cliff and Hunt 1995:71-74, 144146, 205-208), but the excavations into these components were not sufficiently extensive to define the nature of the occupations. Farther upstream at Cooper Lake in Delta and Hopkins Counties, early to middle Caddoan sites with middens and numerous features indicating intensive occupation are common, but only one excavated site-Hurricane Hillyielded convincing evidence of use by fully sedentary groups (Fields et al. 1997:88-89; Perttula 1999).

As for earlier time periods, relatively little is known about late Caddoan use of the lower Sulphur River basin. As noted, two of the three excavated sites at Wright Patman Lake contained late Caddoan components, however, and both appear to represent small farmsteads or hamlets ( elks 1961:36, 65). Based on proximity to the Great Bend of the Red River, it seems likely that this area was occupied by sedentary agriculturalists during this interval. This is supported by the data from $41 \mathrm{M} \times 5$, a small, late Caddoan hamlet in Morris County which contained evidence of perhaps two domiciliary structures associated with burials and which yielded small quantities of maize and squash (Brewington et al. 1995). Recent work at the White Oak Creek Mitigation Area in Bowie, Cass, and Morris Counties (Cliff 1994:197; Cliff and Hunt $1995: 145,206)$ has identified a few sites with late Caddoan components (e.g., 41CS151 and 41CS155/41CS156), but these do not seem to represent intensive occupations, and most may reflect use for procurement/processing purposes rather than domiciliary activities. As represented at Cooper Lake, the upper part of the basin also seems not to have been occupied intensively during this part of the period, although one residential occupation, albeit a short-term one, was documented at the Peerless Bottoms site (Fields et al. 1997:90-91).

Both the upper-middle Sabine River and Cypress Bayou basins appear to have seen substantial occupations during the early Caddoan period. While farmsteads may have been the most common kind of site in the Sabine basin during this period, Perttula (1994) lists a number of known or potential mound sites along the Sabine River or its tributaries in Rains, Smith, Upshur, Harrison, Rusk, and Panola Counties. Many of these probably date to the early and middle parts of the period, indicating the development of hierarchical social and settlement systems. F urther, recent excavations at the Oak Hill site in Rusk County have shown that the region contains some sites representing large planned communities (Perttula and Cruse 1997). A similar situation appears to have occurred in the upper Cypress basin, as Thurmond (1981:450454) notes the presence of three early Caddoan mound sites (Hale, Keith, and Garrison) in Titus and Wood Counties and Nelson and Perttula (1993) identify an early Caddoan mound at the Z. V. Davis-McPeek site in northwestern Upshur County.

Late Caddoan residential sites are common in the upper-middle Sabine and upper Cypress basins, with mound sites apparently being numerous in both valleys (Perttula 1994:12; Perttula et al. 1998; Thurmond 1981: 451, 1985:195). Thurmond (1988:3) suggests that the upper Cypress basin was occupied by an essentially egalitarian society with few individuals of elevated rank. Nonetheless, a number of large cemeteries dating to this interval are known in the upper part of the Cypress Bayou basin (Perttula et al. 1998; Turner 1978, 1992), and it is clear that the Cypress and Sabine valleys supported sizable sedentary populations.

Caddoan lifeways were affected profoundly by European contact. Contact began for the Caddoan area with the coming of the De Soto entrada in 1542, though European diseases spreading through the Native American populations may have affected the Caddo 
by the early 1500s (Perttula 1992:19). Gradually, the pressures of population decline from disease and raiding by other displaced native groups caused a breakdown in traditional boundaries. Between 1700 and 1800, Caddoan groups were on the move, seeking alliances with other surviving Caddo. Perttula (1992: 155) states that sites from this time period generally are small farmsteads and hamlets, sometimes associated with a household cemetery. These farmstead sites comprised dispersed communities (Perttula 1992:155-160). Such groups of sites from this period in the Great Bend include the Spirit Grove locality in the south, including Cedar Grove, Friday, ShawRussell, McClure, Battle, Rube, Russell, and Lester Bend (Schambach et al. 1982; Trubowitz 1984), with Crenshaw in the north (Gregory 1973). On the Red River in northern Bowie County, the Hatchel, Mitchell, and Moores sites, along with the Roseborough Lake site, have historic components (Gilmore 1986; Wedel 1978). These sites probably represent the upper Nasoni village visited by La Harpe and others in the late 1600s and early 1700s (Wedel 1978).

The Roseborough Lake site also is thought to have been the location of a trading post established by Alexis Grappé in ca. 1731-1733 (Gilmore 1986:13-14). Along with nativemade ceramics and lithics, the site produced a variety of European goods including gun parts, axes, knives, ceramics, and glass beads. The post continued as a French garrison until Louisiana was ceded to Spain in 1763, and then it continued only as a trading house until 1778 (Miroir et al. 1975:162-163).

Historic sites on the lower Sulphur River in northeast Cass County include the Atlanta State Park site (Harris et al. 1980:231-239), the Clements site (Dickinson 1941:117-132; Lewis 1987), and the Hunt site (J ackson n.d.). Based on the ceramics and trade goods recovered, the sites are thought to have been occupied before the mid-eighteenth century (Perttula 1992:171-172), and they may have been associated with the Nasoni Caddo, who controlled a portage on the Caddo Trace connecting the northern Caddoan groups with the southern Caddoan groups of east Texas. In contrast, no historic Native American sites were recorded in the extensive work at Cooper
Lake in the upper Sulphur basin, and it appears that this part of the valley was not settled during this time (Perttula 1999:31).

By 1790, the various Caddoan groups living in the Great Bend region had abandoned the area after severe raids by the Osage. They moved south to join with groups living near Caddo Lake in the Cypress Basin. One of the most important localities in this area is the recently excavated Timber Hill site in Marion County, which was occupied by the Kadohadacho and other Caddo groups in the first half of the nineteenth century prior to their removal from east Texas (Parsons 1999). Documented historic Caddo sites in the Sabine River basin include the so-called "Kinsloe focus" sites in Gregg, Harrison, Panola, and Rusk Counties (J ones 1968), as well as a few sites upstream at Lake Fork Reservoir (Perttula 1992:174). Other important historic Native American sites in this part of the Sabine valley include the Pearson and Gilbert sites in Rains County, which apparently represent Wichita groups who moved south into Texas in the seventeenth and eighteenth centuries (Duffield and J elks 1961; J elks 1967).

\section{North-Central Texas}

This synopsis deals with the northern parts of the Dallas and Fort Worth Districts and the western part of the Paris District, extending from J ack and Palo Pinto Counties on the west to Collin County on the east and from Dallas County on the south to Grayson County on the north. This is an environmentally diverse area. The northern Blackland Prairie occupies the eastern part, while alternating oak woodlands and grasslands associated with the Cross Timbers and Grand Prairie mark the central part. The far western edge intersects the eastern Rolling Plains. The main river that drains the area is the upper Trinity and its numerous tributaries; the Red River flows along the north side of the region, while the Brazos River drains the southwestern part.

Previous archeological investigations within north-central Texas vary in intensity and quality. Much work has been done in the Trinity River drainage within the northern part of the Dallas District and eastern Fort 
Worth District, whereas significantly less work has taken place in the western and southwestern Fort Worth District. For instance, on the Trinity River's East Fork, several projects have made significant contributions, including Lavon Lake (Dawson and Sullivan 1973; Lynott 1975; Stephenson 1949) and Lake Ray Hubbard (Harris and Suhm 1963; Lorrain and Hoffrichter 1968; Ross 1966). Significant archeological projects on the upper Elm Fork of the Trinity in the DallasFort Worth-Denton area include Ray Roberts Reservoir (Ferring 1987; Ferring and Yates 1997; Prikryl and Yates 1987; Skinner et al. 1982), Lewisville Lake (Brown and Lebo 1991; Ferring and Yates 1998; Stephenson 1950b), and Grapevine Lake (Ferring 1975; Morgan 1975). Along the West Fork of the Trinity River and its tributaries, intensive investigations have occurred only at Mountain Creek Lake (Peter and McGregor 1988). Beyond the headwaters of the Trinity and along the Red River in the northwest corner of the Paris District, investigations have occur-red at Lake Texoma (Prewitt and Lawson 1972) and Hubert Moss Lake (Lorrain 1969). Investigations in the Brazos River basin as it passes through the southwestern part of the Fort Worth District include Lake Granbury (Skinner 1971) and Possum Kingdom Lake (Brayshaw 1970; Hughes 1942; Krieger 1946).

Much of the information generated by the reservoir investigations has yet to be synthesized. The following discussion of the prehistory of north-central Texas draws on the few synthetic and/or summary sources available, especially those by Prikryl (1990, 1993). Story's (1990) summary of archeology on the east Texas Gulf coastal plain also draws on some of the work done in the upper Trinity basin, while Lynott's (1981) discussion of prehistoric adaptations in the Cross Timbers, Grand Prairie, and Rolling Plains provides connections to an overview by Hofman et al. (1989) of southern Great Plains archeology.

As with many other areas of Texas, Paleoindian materials in north-central Texas often are found in surface contexts or mixed with later materials. The generally low density of Paleoindian artifacts and sites and the tendency for projectile points to be made from nonlocal lithics have led investigators to char- acterize these populations as highly mobile with low regional densities (Lynott 1981:100101). Megafauna fossil finds within the region have led some investigators to conclude that subsistence practices of Paleo-indian peoples were linked to mammoth and bison. However, no kill or butchering sites similar to those identified for the southern Plains have ever been discovered (Prikryl 1990, 1993).

Generally, the Paleoindian period in north-central Texas is considered to extend from ca. 10,000 to 6500 B.C. (Prikryl 1993:199). Point types often found that can be associated with the early to late parts of the period include Clovis, F olsom, Dalton, Plainview, San Patrice, and Scottsbluff. The most common types recognized are Dalton and Plainview (Prikryl 1990). The majority of the recorded Paleoindian sites cluster in the upper Trinity drainage where the most intensive archeological investigations have taken place, though often these sites consist of no more than one or two points. However, the Acton site, located in Hood County on a $\mathrm{T}_{2}$ terrace of the Brazos River overlooking Lake Granbury, is significant for the number of Plainview and Dalton (Meserve) points it produced $(n=72)$. A variety of other lithic tools such as gouges, scrapers, and burins also were recovered. Unfortunately, the Paleoindian occupation could not be isolated from Archaic-period occupations of the site.

Interestingly, the only two investigated sites in north-central Texas with apparently discrete Paleoindian components are early, as both produced Clovis projectile points. These sites are the Lewisville and Aubrey sites located in the northern part of the Dallas District. The Lewisville site contained 27 hearth features with an associated Clovis point and other sparse lithics in a near-surface context (Crook and Harris 1957, 1958; Story 1990: 182-184), and the Aubrey site contained lithic debitage and Clovis points buried beneath $8 \mathrm{~m}$ of Holocene alluvium on the EIm Fork floodplain (Ferring 1989). Both sites also contained a variety of faunal remains both large and small, although only small game, the largest being white-tailed deer, can be associated comfortably with the Clovis occupation at the Lewisville site. The preponderance of small game at the Aubrey site could be interpreted 
as representing a more generalized pattern of foraging than the reliance on mammoth and bison apparently demonstrated at Clovis sites on the southern Plains (Hofman 1989:31-32). Such a divergence in subsistence patterns may reflect an inherent adaptability of Clovis technology to changing environmental conditions encountered as early populations spread southeastward into Texas (Ferring and Yates 1997).

The Archaic period extends from ca. 6500 B.C. to A.D. 700, with ca. 2,500-year segments often considered as early, middle and late divisions of the period (Prikryl 1993:199). Diagnostic artifacts for the period are similar to those of adjacent regions, although developing a sound chronological sequence of diagnostic artifacts has proven difficult because many of the investigations have focused on surface manifestations. Prikryl (1990) suggests that early Archaic projectile points include early split-stemmed varieties and possibly Angostura, while middle Archaic points include basal-notched forms such as Bell, Andice, and Calf Creek along with Wells, Dawson, Carrollton, and Bulverde. Late Archaic point types reportedly include Castroville, Marshall, Edgewood, Ellis, Trinity, Palmillas, Yarbrough, Dallas, Godley, Elam, and Gary (Prikryl 1990). At one time, the Carrollton and Elam foci were defined to refer to the middle and late Archaic respectively (Crook and Harris 1952, 1954). However, reevaluation of the type-site artifacts showed that the materials were mixed such that perpetuation of these foci provides little interpretive value (Hofman 1989:57; Prikryl 1990:73-74). Some of this mixing and the generally low numbers of early and middle Archaic sites may be due to extensive erosion of mid-Holocene deposits. This type of erosion has been documented for the Brazos drainage immediately west of the Fort Worth District in Young, Stephens and Throckmorton Counties (Ensor et al. 1992:303).

Though few isolable components have been analyzed for the various divisions of the Archaic-period in north-central Texas, slowly increasing populations responding to warmer and drier environmental conditions have been postulated to explain the overall archeological record of the period (Lynott 1981:103-104; Story 1990:212). It is thought that these factors may have led Archaic populations of the
Cross Timbers and prairie areas of northcentral Texas to develop a diversified hunting and gathering pattern based on bottomland resources of the rivers and major creeks, while populations on the Rolling Plains maintained a focus on bison hunting (H ofman 1989:57-58). Projectile points of the period were fashioned from local lithic materials suggesting that populations were less mobile than their Paleoindian predecessors. Less mobility also may suggest refinement of the diversified subsistence pattern to include scheduling of resource use within more-restricted areas. Evidence from late Archaic sites at Mountain Creek Lake (Peter and McGregor 1988) and Ray Roberts Reservoir (Ferring and Yates 1997) indicates repeated site occupation by small groups, which could support the resource scheduling hypothesis. Still, even with refinement of resource utilization, evidence of dietary stress has been found on Iate Archaic human skeletal materials (Ferring and Yates 1997:305; Gill-King 1987:103-104).

Human burials are common in the archeological record of the late Archaic and Late Prehistoric periods of at least the eastern part of north-central Texas (Prikryl 1993). Some of these burials are associated with Wylie pit features, which are large man-made depressions measuring ca. $16 \mathrm{~m}$ in diameter and 2$4 \mathrm{~m}$ in depth. These features were first identified at a series of sites along the East Fork of the Trinity River and were considered an important trait of the Wylie focus (Harris and Suhm 1963; Stephenson 1952; Wilson 1946). Radiocarbon assays from pits at the Upper Rockwall and Sister Grove Creek sites in the area of Lavon Lake suggest that the pits and the Wylie focus were associated with the Late Prehistoric period (Lynott 1975:117; Ross 1966). Lynott (1977) widened the temporal span by incorporating a late Archaic phase into the focus definition. Subsequent work on Wylie pits at Richland-Chambers Reservoir to the south confirmed their late Archaic age (Bruseth and Martin 1987:165). However, the wide range of artifact types associated with them and the long span of time represented made it clear that the Wylie focus was not a useful construct. Bruseth and Martin (1987: 280-284), while discarding the focus as unusable, further supported Lynott's (1975) 
original interpretation of the pits as being associated with large-scale food processing. Their interpretation likens the pits to the burned rock middens of central Texas, with both representing group aggregations.

Group aggregation and large-scale manipulation of subsistence resources, as represented by the Wylie pits and the human burials they contain, may be indicative of societal changes that continued through the Late Prehistoric period. Habitation structures indicating increased sedentism, at least in certain places and at certain times, have been found in some Late Prehistoric sites, along with cultigens such as corn and arrow points and ceramics indicating important technological changes. Also, there may be evidence (e.g., the distinction between burials placed inside and outside Wylie pits) of differential mortuary practices that could reflect a shift toward a hierarchical social structure, although this evidence is nowhere near as strong as that for the Caddoan area of northeast Texas. Prikryl (1990, 1993) defines two chronological periods for the Late Prehistoric in north-central Texas, which he links to particular projectile point and ceramic types.

Prikryl's (1990, 1993) Late Prehistoric I period (A.D. 700-1200) is marked by the arrow point types Scallorn, Catahoula, Steiner, Alba, and Bonham. Ceramic vessels are mostly grog tempered and undecorated, but there is some evidence of influences from other regions in that some locally manufactured wares display designs similar to those associated with east Texas Caddo ceramic types. Evidence for corn and structures has been found at sites at Mountain Creek Lake as well as to the north at Hubert Moss Lake near the Red River (Lorrain 1969; Martin 1994; Peter and McGregor 1988). Farther west, cultural changes also were taking place on the Rolling Plains, though this area held onto its Archaic lifestyle even after technological innovations such as the bow and arrow were accepted (Lynott 1981:106).

During the Late Prehistoric II period (A.D. 1200-1700), influences from the southern Plains became pronounced in the Cross Timbers and prairie areas. These influences coincided with an increase in bison herd size in north-central Texas (Lynott 1981:106; Prikryl 1990:80). Bison was important to subsistence, but shrinking procurement territory sizes due to population increases continued the trend toward horticulture and settled village life (Harris and Harris 1970; Morris and Morris 1970). In terms of technology, a Plains Indian tool assemblage was common (Prikryl 1990: 80). Items associated with this assemblage include calcareous-tempered ceramic vessels, some of which fit the description for the type Nocona Plain (shell tempered), and unstemmed triangular arrow points such as Maud, Fresno, Harrell, and Washita, as well as Perdiz points. Tools specific to bison processing include snub-nosed or thumbnail scrapers and edgebeveled Harahey knives. Bison scapula hoes, which also are common in Plains Indian sites, have been recovered from sites in the Lewisville Lake and Lavon Lake areas of Denton and Collin Counties (Barber 1969:118119; Harris 1945).

The Plains Indian influences associated with settled village life were used to define the Henrietta complex of north-central Texas. This complex, based on Krieger's (1946) moreexpansive Henrietta focus, extends from the Red River south along the headwaters of the Trinity and Brazos Rivers. The type site, M. D. Harrell, is located along the Brazos River in Young County just northwest of Palo Pinto County in the drainage basin for Possum Kingdom Reservoir (Krieger 1946). The Harrell site and other associated sites contain middens, house structures, rock hearths, storage pits, and burials, and they most often are located on sandy knolls or terraces over-looking river valleys (Brooks 1989:85-86; F orrester 1994:249-266). Excavated sites attributed to the Henrietta complex include the Coyote and Glass sites located on the Red River in Montague County (Lorrain 1967:24-44; Woodall 1967a), and it is clear that sites such as Dillard in Cooke County are related as well (Martin 1994).

The Henrietta complex as an investigative tool can be limiting since its loose definition tends to obscure local differences. More recent investigations in the upper Trinity River drainage have tended to highlight the local differences. For instance, at Ray Roberts Reservoir Ferring and Yates (1997:305) see local trends emerging independent of extraregional influences. They cite the lack of evidence for 
extensive maize horticulture and the preponderance of short-term logistical camps as the basis of their hypothesis. Similarly, Peter and McGregor (1988:367) demonstrated that occupation of the Mountain Creek drainage was less intensive in the Late Prehistoric II period than before and that maize horticulture, if practiced at all, was limited. Yet sites in both of these parts of the Trinity drainage have produced items characteristic of Plains Indian sites, such as shell-tempered ceramics and diagnostic lithic tools.

By the eighteenth century, immigrant Plains Indian groups had moved into and beyond north-central Texas, and their documentation by traders and explorers marks the start of the historic period. Documentary sources suggest that the Tonkawa, Apache, Comanche, Wichita, Kitsai, Yojaune, Caddo, Delaware, and Kickapoo traversed the region at various times during the period (Campbell 1983; Newcomb 1961; Newcomb and Campbell 1982). However, archeological sites that can be associated definitely with historic groups are few. The Wichita are known to have moved into Texas from Oklahoma and Kansas in the early 1700s. Sites attributable to the historic Witchita have been identified at the edges of north-central Texas. Among these are the Stansbury site located in Hill County, now inundated by Lake Whitney (Stephenson 1970). Excavations at the site produced burials, house structures, storage pits, and a variety of aboriginal artifacts along with European ceramics, glass beads, metal arrow points, and flintlock musket parts. A cluster of Wichita sites also occurs to the north along the Red River in Montague County. These sites are known collectively as "Spanish Fort" and occur on both the Oklahoma and Texas sides of the river. Woodall (1967b) excavated one of these sites, named the Upper Tucker site; it produced artifacts and features similar to those discovered at the Stansbury site. Wichita sites both on the Brazos and Red Rivers were located atop high terraces that overlook the rivers.

\section{Northeast Margin of Central Texas}

The archeological record of the central Texas area is known from decades of inves- tigations at various sites throughout areas of the Edwards Plateau, its highly dissected eastern and southern margins, and the margins of physiographic regions to the east and south (see Collins [1995] for review). Traditionally, the central Texas archeological area has included the middle Brazos River valley and Lampasas Cut Plain (e.g., Prewitt 1981; Suhm 1960), i.e., the western part of the Waco District and the southwestern part of the F ort Worth District, and a number of project areas that have contributed important information are located in this region, e.g., Stillhouse Hollow Lake, Belton Lake, Fort Hood, Waco Lake, the Hog Creek project, and Whitney Lake. These are on the periphery of the central Texas area, however, and their archeological records and projectile point style sequences contain elements that suggest influences and contacts to varying degrees over time with areas to the east and northeast (cf., Collins 1995; J ohnson and Goode 1994).

Paleoindian (10,000-6500 B.c.) occupations of the central Texas area are represented by surfacial and deeply buried sites, rockshelter sites, and isolated artifacts. The period often is described as having been characterized by small but highly mobile bands of foragers who were specialized hunters of Pleistocene megafauna. However, a more accurate view of Paleoindian lifeways probably includes the utilization of a much wider array of resources. Recent investigations at the Wilson-Leonard site in Williamson County just south of the Waco District support this view and have challenged the fundamental defining criterion of the Paleoindian period, that of artifacts in association with late Pleistocene megafauna (Masson and Collins 1995).

Collins (1995) divides the Paleoindian period into early and late subperiods. Two projectile point styles, Clovis and Folsom, are included in the early subperiod. Clovis chipped stone artifact assemblages, including the diagnostic fluted lanceolate Clovis point, were produced by bifacial, flake, and prismaticblade techniques on high-quality and oftentimes exotic lithic materials (Collins 1990). Along with chipped stone artifacts, Clovis assemblages include engraved stones, bone and ivory points, stone bolas, and ochre (Collins 1995:381; Collins et al. 1992). Clovis, 
as well as a number of later Paleoindian dart points, have been recovered from the Gault site in Bell County (Collins and Brown 2000) and the Triple $S$ Ranch site in Hamilton County (Hatfield 1997). Probable Clovis polyhedral blade cores have been found in Hamilton County (Goode and Mallouf 1991). Analyses of Clovis artifacts and site types suggest that Clovis peoples were well-adapted, generalized hunter-gatherers with the technology to hunt larger game but not rely on it solely. In contrast, Folsom tool kits, consisting of fluted Folsom points, thin unfluted (Midland) points, large thin bifaces, and end scrapers, are more indicative of specialized hunting, particularly of bison (Collins 1995: 382). Folsom points have been recovered from Horn Shelter No. 2 along the Brazos River (Redder 1985; Watt 1978).

Postdating Clovis and Folsom points in the archeological record are a series of dart point styles for which the temporal, technological, or cultural significance is unclear. Several of these styles were recovered from Horn Shelter No. 2 and include Plainview, Scottsbluff, Dalton, and San Patrice (Watt's [1978] Brazos Fishtail points) type. Often, the Plainview type name is given to any unfluted, lanceolate dart point, however, Collins (1995: 382) has noted that many of these points typed as Plainview do not parallel Plainview type-site points in thinness and flaking technology. Also problematic are the chronological position and cultural significance of Dalton and San Patrice dart points. Components and artifact and feature assemblages of the later Paleoindian subperiod appear to be Archaiclike in nature and, in many ways, may repre sent a transition between the early Paleoindian and succeeding Archaic periods (Collins 1995:382).

The Archaic period for central Texas dates from ca. 6500 B.C. to A.D. 700 (Collins 1995). The Archaic period generally is believed to represent a shift toward the hunting and gathering of a wider array of animal and plant resources and a decrease in group mobility (Willey and Phillips 1958:107-108). In the eastern and southwestern U.S. and on the Great Plains, the Archaic period is succeeded by the development of horticultural-based, semisedentary to sedentary societies. In these areas, the Archaic truly represents a developmental stage of adaptation as Willey and Phillips (1958) define it. For central Texas, this notion of the Archaic is somewhat problematic. An increasing amount of evidence suggests that Archaic-like adaptations were in place prior to the Archaic (see Collins 1995: 381-382; Collins et al. 1989; Masson and Collins 1995) and that these practices continued into the succeeding Late Prehistoric period (Collins 1995:385; Prewitt 1981:74). In a real sense, the Archaic period of central Texas is not a developmental stage but an arbitrary chronological construct and projectile point style sequence. This sequence is based on several decades of archeological investigations at stratified Archaic sites along the eastern and southern margins of the Edwards Plateau. Collins (1995) and J ohnson and Goode (1994) have divided this sequence into three partsearly, middle, and late-based on perceived (though not fully agreed upon by all scholars) technological, environ-mental, and adaptive changes.

Early Archaic (6500-4000 B.C.) sites are small and their tool assemblages are diverse (Weir 1976:115-122), suggesting that populations were highly mobile and densities low (Prewitt 1985:217). It has been noted that early Archaic sites are concentrated along the eastern and southern margins of the $E$ dwards Plateau (J ohnson and Goode 1994; McKinney 1981). This distribution may be indicative of climatic conditions at the time, given that these areas have more reliable water sources and a more diverse resource base than other parts of the region. Early Archaic projectile point styles include Angostura, Gower, Wells, Martindale, and Uvalde. Manos, metates, hammerstones, Clear Fork and Guadalupe bifaces, and a variety of other bifacial and unifacial tools are common to early Archaic assemblages. The construction and use of rock hearths and ovens reflect a specialized subsistence strategy (exploitation of roots and bulbs?) during the early Archaic. These burned rock features most likely represent the technological predecessors of the larger burned rock middens extensively used later in the Archaic period (Collins 1995:383). Significant early Archaic sites include the Youngsport site in Bell County (Shafer 1963), which yielded 
Gower and Wells dart points from deeply buried contexts.

During the middle Archaic period (40002000 B.C.), the number and distribution of sites, as well as site size, increased due to probable increases in population densities (Prewitt 1981:73; Weir 1976:124, 135). Macrobands may have formed at least seasonally, or an increased number of small groups may have utilized the same sites for longer periods of time (Weir 1976:130-131). A greater reliance on plant foods is suggested by the presence of burned rock middens toward the end of the middle Archaic, although tool kits still imply a strong reliance on hunting (Prewitt 1985:222226). Middle Archaic projectile point styles include Bell, Andice, Taylor, Baird, Nolan, and Travis. Bell and Andice points reflect a shift in lithic technology from the preceding early Archaic Martindale and Uvalde point styles (Collins 1995:384). J ohnson and Goode (1994:25) suggest that the Bell and Andice darts are parts of a specialized bison hunting tool kit. They also suggest that the beginning of the middle Archaic was marked by an influx of bison and bison-hunting groups from the Eastern Woodland margins during a slightly more mesic period. Bell points and bison remains were recovered from the Landslide site in Bell County (Sorrow et al. 1967). Bison disappeared as morexeric conditions returned during the later part of the middle Archaic. Later middle Archaic projectile point styles represent another shift in lithic technology (Collins 1995:384; J ohnson and Goode 1994: 27). Prewitt (personal communication 2000) postulates that the production and morphology of Travis and Nolan points are similar to projectile points from the Lower Pecos region. Such characteristics as beveled stems and overall morphology may have originated in the Lower Pecos, since these elements appeared earlier in the Lower Pecos than they did in central Texas. Shafer's (1963:67) surprise that Nolan points, which are more common in sites to the south and west, were not found in greater numbers at the Youngsport site might support the idea that bearers of these darts came out of the Lower Pecos and moved into adjacent portions of central Texas, but did not utilize all portions of central Texas equally. At the same time, a shift to morexeric conditions bore witness to the construction and use of burned rock middens. J ohnson and Goode (1994:26) believe that the dry conditions promoted the spread of xerophytic plants, such as yucca and sotol, and that it was these plants that were collected and cooked in large rock ovens by late middle Archaic peoples.

During the succeeding late Archaic period (2000 B.C. to A.D. 700), populations continued to increase (Prewitt 1985:217). Within stratified Archaic sites, such as Youngsport, the Baylor site in McLennan County (Story and Shafer 1965), and the Steele site in Hill County (Stephenson 1970), the late Archaic components contain the densest concentrations of cultural materials. The establishment of large cemeteries along drainages suggests strong territorial ties by certain groups (Story 1985a:40). A variety of projectile point styles appeared throughout the late Archaic period. J ohnson and Goode (1994:29-35) divide the late Archaic into two parts based on increased population densities and perceived evidence of Eastern Woodland ceremonial rituals and religious ideological influences. Middle Archaic subsistence technology, including the use of burned rock middens, continued into the late Archaic period. Collins (1995:384) states that, at the beginning of the late Archaic period, the construction and use of burned rock middens reached its zenith and that their use declined during the latter half of the late Archaic. However, there is mounting chronological data that midden formation and use culminated much later and that this high level of use continued into the early Late Prehistoric period (Black et al. 1997:270-284; Kleinbach et al. 1995:795). A picture of prevalent burned rock midden use in the eastern part of the central Texas region after 2000 B.P. is gradually becoming clear. This scenario parallels the widely recognized occurrence of post2000 B.P. middens in the western reaches of the Edwards Plateau (see Goode 1991). The use of burned rock middens appears to have been a major part of the subsistence strategy, as a decrease in the importance of hunting, inferred from the low ratio of projectile points to other tools in site assemblages, may have occurred (Prewitt 1981:74).

The Late Prehistoric period (A.D. 7001700 ) is marked by the introduction of the bow 
and arrow and then ceramics into central Texas. Population densities dropped considerably from their late Archaic peak (Prewitt 1985:217). Subsistence strategies did not differ greatly from the preceding period, although bison became an important economic resource during the latter part of the Late Prehistoric period (Prewitt 1981:74). The use of burned rock middens for plant food processing(?) continued throughout the Late Prehistoric period (Black et al. 1997; Kleinbach et al. 1995: 795). Horticulture came into play very late in the region but was of minor importance to overall subsistence strategies (Collins 1995:385).

In central Texas, the Late Prehistoric period generally is associated with the Austin and Toyah phases (J elks 1962; Prewitt 1981: 82-84). Story (1990:364), in her overview of the middle Brazos River basin, argues for a period/horizon characterized by Alba points and early Caddoan-like pottery intermediate between the Austin and Toyah phases. Evidence of this proposed archeological manifestation was found at the Chupik site in McLennan County (Watt 1953). Much of what we know about the Austin and Toyah phases comes from rockshelter sites in and around Whitney Lake in Bosque and Hill Counties (see J elks 1962; Stephenson 1970). Austin and Toyah phase horizon markers, ScallornEdwards and Perdiz arrow points, respectively, are distributed across most of the state. The introduction of Scallorn and Edwards arrow points into central Texas often is marked by evidence of violence and conflict, as many excavated burials contain these point tips in contexts indicating they were the cause of death (Prewitt 1981:83). Subsistence strategies and technologies (other than arrow points) did not change much from the preceding late Archaic. This continuity is recognized by Prewitt's (1981) use of the term "Neoarchaic." In fact, J ohnson and Goode (1994:39-40) and Collins (1995:385) state that the break between the late Archaic and the Late Prehistoric could be represented easily and appropriately by the break between the Austin and Toyah phases.

Around A.D. 1000-1200, slightly morexeric or drought-prone climatic conditions returned to the region, and bison returned in large numbers (Huebner 1991; Toomey et al.
1993). Utilizing this vast resource, Toyah phase peoples were equipped with Perdiz point-tipped arrows, end scrapers, fourbeveled-edge knives, and plain bone-tempered ceramics. The technology and subsistence strategies of the Toyah phase represent a completely different tradition than the preceding Austin phase. Contact with Caddoan groups to the east and northeast is represented by Caddoan ceramics in site assemblages, particularly in the eastern peripheral areas of central Texas (e.g., Stephenson 1970). Collins (1995:388) states that burned rock middens fell out of use, as bison hunting and group mobility obtained a level of importance not witnessed since Folsom times. While the importance of bison hunting and high group mobility hardly can be disputed, the cessation of burned rock midden use during the Toyah phase is tenuous. A recent examination of Toyah-age radiocarbon assays and assemblages by Black et al. (1997) suggests that their association with burned rock middens represents more than a "thin veneer" capping Archaic-age features. Black et al. (1997) claim that burned rock midden use, while not as prevalent as in earlier periods, played a role in the adaptive strategies of Toyah peoples.

Historical accounts of Native Americans and their interactions with the Spanish, the Republic of Mexico, the Texas Republic, and the United States throughout the region are provided by Hester (1989), J elks (1970), and Newcomb (1961). The late seventeenth and early eighteenth centuries was an era of morepermanent contact between Europeans and Native Americans, as the Spanish moved northward out of Mexico to establish settlements and missions on their northern frontier. There is little available information on aboriginal groups and their ways of life except for the fragmentary data gathered by the Spanish missionaries. The inevitable and disastrous impacts to native social structures and economic systems by disease and hostile encounters with Europeans and intruding groups, such as the Apache, were already under way at this time. Historically, three groups occupied the study area: Wichita-speaking groups consisting of the Tawakoni, Waco, and Kichai; Caddoan tribes comprised of the Anadarko, Hasinai, and Kadohadacho; and the Tonkawa. 
The Apaches and Comanches also were present, but later in time.

Athanase de Mézières's expeditions along the Brazos River in the 1770s encountered two large Tawakoni villages along a stretch from present-day Waco to the vicinity of the Nolan River (J elks 1970; Krieger 1996). Based on archeological evidence and historical documents, the Stansbury site near Whitney Lake was occupied by the Tawakoni in the 1770s1780s (J elks 1970), and Story (1985b) identifies a number of other sites in the Waco area, e.g., Stone, Gas Plant, and Walton, that appear to be associated with occupations by Wichita groups. By the mid-1830s, the Stansbury site was occupied by the Caddoanspeaking Hasinai, but the village moved in 1846 approximately 10 miles up the Brazos near the locale that would become Fort Graham in 1849. Fort Graham was established to provide protection for the growing number of Euro-American settlements in the area from Native American hostilities, but it was occupied only briefly by the U nited States military and abandoned in 1853 (J elks 1970). Tonkawa groups seeking protection from Comanche raids settled near here. By the 1870s, the remaining groups of Tonkawa, Apache, and Comanches were removed from the area and placed on reservations in Indian territory.

\section{Central Blackland Prairie}

This synopsis focuses on the eastern part of the Waco District and the southern Dallas District, an area that is more coherent as a natural region than a cultural one. Most of this area is within the central part of the Blackland Prairie, extending from Bell County at the south end of the Waco District north to Ellis and Kaufman Counties in the Dallas District. Also included, however, are small areas of Oak Woodlands in the eastern parts of Limestone and Navarro Counties. The northern part of the region is drained by the Trinity River and two of its major tributaries, Chambers and Richland Creeks. The Brazos River and two of its major tributaries, the Navasota and Little Rivers, flow through the southern part.

The archeology of this area, or at least its core part, is not well understood because few large-scale projects involving excavations at numerous sites have been undertaken. Among those project areas that have contributed important information are the Superconducting Super Collider in Ellis County, Bardwell Lake in Ellis County, Cedar Creek Reservoir in Kaufman and Henderson Counties, RichlandChambers Reservoir in Navarro and Freestone Counties, Navarro Mills Reservoir in Navarro and Hill Counties, Aquilla Lake in Hill County, and Lake Limestone in Limestone County (see Guy [1990], Prikryl [1993], and Yedlowski et al. [1998] for more-detailed information on these and other regionally relevant projects). However, three of theseCedar Creek Reservoir, Richland-Chambers Reservoir, and Lake Limestone-are on the eastern margin of the area and tell us more about Native American adaptations to the Oak Woodlands than the Blackland Prairie. Aquilla Lake also is geographically marginal, lying at the boundary between the Blackland Prairie and the Eastern Cross Timbers. Another bias stems from the fact that all of these project areas, except Lake Limestone, are in the northern part of the region. There have been no major archeological projects on the Blackland Prairie in the Brazos basin portion of this region, although there is one notable project just to the south-Granger Lake in Williamson County-that provides important information about how this part of the area was used prehistorically.

The data from Granger Lake (Hays 1982; Prewitt 1974, 1982), as well as information supplied by avocational archeologists with collections from the Little River valley (EIton R. Prewitt, personal communication 2000), show that the prehistory of the Blackland Prairie south of the Brazos River has much more in common with the prehistory of the Edwards Plateau and central Texas to the west than with that of areas to the north. In fact, at least for certain time periods, the same may be said, albeit less strongly, for the western edge of the Blackland Prairie north of the Brazos, e.g., at Aquilla Lake (Brown 1987). Because the prehistory of central Texas as seen on the Edwards Plateau is summarized above, it is not reiterated here, regardless of its applicability to the southeastern section of the Waco 
District. Instead, this discussion focuses on the rest of the central Blackland Prairie and immediately adjacent Oak Woodlands to the east.

Sites such as Horn Shelter No. 2 and Wilson-Leonard have provided substantial information on the Paleoindian period for the area to the west of this region (see Northeast Margin of Central Texas above), but there are no excavated and reported Paleoindian components on the central Blackland Prairie itself. Nonetheless, a variety of early points have been found, largely in surface contexts, and it is clear that this part of Texas was used throughout the period from ca. 10,000 to 6500 B.C. Presumably, this use was by huntergatherer groups with low population densities and high residential mobility. An analysis of materials collected by C.K. Chandler and other avocational archeologists from sites chiefly in Ellis County during the Superconducting Super Collider project identified a handful of Paleoindian projectile points typed as Clovis, Plainview, Dalton, Golondrina, and San Patrice, along with several untyped lanceolate specimens (Yedlowski et al. 1998:519520). Other early materials from the area include one Folsom from the Wild Bull site in Henderson County (Story 1965:189-190); a few San Patrice points from RichlandChambers Reservoir (McGregor and Bruseth 1987:176-179); several Brazos Fishtail and Plainview points from Aquilla Lake (Brown 1987:44-1 through 44-2); a cache of 23 prismatic blades from a site in Navarro County (Young and Collins 1989); probably the Brookeen Creek cache of 173 blades and flakes from Hill County (Mallouf 1981); and one Folsom point from Lake Limestone (Mallouf 1979:44). J ust east of Lake Limestone in Leon County, the Lambs Creek knoll site yielded a Golondrina point, several untyped lanceolate points, and a radiocarbon assay of 8940 B.P., but these were mixed with later materials and hence of limited interpretability (Fields 1995: 304).

Mixing of components also has hampered interpretations about how the region was used by Native Americans during the lengthy Archaic period, ca. 6500 B.C. to A.D. 700. Because few pure Archaic components have been excavated, particularly ones dating to the first two-thirds of the period, it is difficult to say much about artifact chronologies, subsistence practices, or settlement strategies. A variety of projectile point styles traditionally associated with the early and middle parts of the Archaic period in central Texas-for example, Andice, Angostura, Bell, Gower, Hoxie, Martindale, Nolan, Travis, and Uvalde (Yedlowski et al. 1998:520)-were identified during analyses for the Superconducting Super Collider project (while a host of other types perhaps dating to this time and later were identified as well, their chronologies are less certain), but these points are few in number and do not appear to represent major occupation of this part of the Blackland Prairie. Demonstrably early points were even scarcer at the nearby Pecan Springs site at Bardwell Reservoir and the Strawn Creek site at Navarro Mills Reservoir, with a Hoxie point from Pecan Springs being the clearest example (Duffield 1963; Sorrow 1966). Similarly, early to middle Archaic points, including Angostura, Bell/Andice, Gower, Hoxie (?), and Martindale, were found only in small numbers at Aquilla Lake to the west (Brown 1987:44-12 through 44-21), suggesting limited use of the valleys of Aquilla and Hackberry Creeks during this time.

The relatively intensive work at RichlandChambers Reservoir and Lake Limestone (and J ewett Mine just to the east) suggests a similar conclusion for the western edge of the Oak Woodlands, although for both areas it has been noted that data pertaining to the early to middle Archaic may be scarce in part because sites dating to this interval lie deeply buried or were removed by extensive erosion during the mid-Holocene (Fields 1995:302; McGregor and Bruseth 1987:229). Only a few radiocarbon assays predating 4000 B.P. were obtained from these project areas, and only one excavated site, Charles Cox at the J ewett Mine, contains a substantial component that might be early or middle Archaic in age (Fields 1995: 303, 304-305). This component appears to be represented by a variety of untyped dart points with expanding and parallel stems, but later materials are mixed in as well, and the deposits were not dated by radiocarbon. Points dated to this interval in central Texas, for example, Bell/Andice/Calf Creek and Hoxie, 
occur at both Richland-Chambers Reservoir and the J ewett Mine, but only in very small numbers.

A much different picture is presented for the late part of the Archaic period, i.e., after about 4000 B.P. All parts of the central Blackland Prairie that have been studied archeologically contain sites dating to this period, and the late Archaic represents the earliest time for which much is known about Native American lifeways. Both the Pecan Springs and Strawn Creek sites on the Blackland Prairie proper yielded such late Archaic point types as Gary, Dawson, and Yarbrough, although they tend to be mixed with materials from later occupations (Duffield 1963:60-62; Sorrow 1966:56-61). The surface collections analyzed during the Superconducting Super Collider project also contained these types, as well as a number of late Archaic types common in central Texas-including Bulverde, Darl, Ensor, Marcos, Marshall, Montell, and Pedernales-and a variety of probably late Archaic forms more characteristic of the northcentral and eastern parts of the state, such as Carrollton, Edgewood, Elam, Ellis, Kent, and Neches River oletha (Yedlowski et al. 1998: 520-521). Noting the relatively high frequency of late Archaic projectile points, Yedlowski et al. (1998:527-528, 533) suggest that the region saw an increase in utilization by huntergatherers as a result of moister climatic conditions than before, presumably associated with greater productivity in subsistence resources. They also note that, while the projectile point evidence indicates interaction with groups living in central Texas proper, larger proportions of points indicate affinities with eastern Texas than during the early and middle Archaic.

Brown (1987:44-22 through 44-26) presents similar conclusions concerning an increase in occupational intensity (increased population?) and increased interaction to the north and east during the late Archaic for the Aquilla Lake area based on an increase in the number of sites with late Archaic diagnostics and the dominance of the Gary dart point type. The same certainly may be said for those project areas at the eastern edge of the region, i.e., Cedar Creek Reservoir, Richland-Chambers Reservoir, and Lake Limestone. Two of the 3 excavated sites at Cedar Creek Reservoir have strong late Archaic components represented by numerous Gary points and a variety of other lithic tools (Story 1965), while at least 15 sites at Richland-Chambers Reservoir and 12 of the excavated sites at Lake Limestone and adjacent J ewett Mine have identifiable components of this age. In addition to constellations of projectile point styles (e.g., Dawson, Gary, Godley, Kent, Neches River oletha, and Yarbrough) that indicate ties more to the north and east than to the south and west, each of these areas has yielded information suggesting that ceramics may have been introduced into the material culture of local groups during the latest part of the late Archaic, as they were across most of Texas to the east (where this interval usually is called the Early Ceramic period, and sometimes the Woodland period).

At Cedar Creek Reservoir, there are hints in the distributional data from the Lacy and Gossett Bottoms sites that the initial use of ceramic containers preceded introduction of the bow and arrow, although it is difficult to be certain because the sites were not well stratified and the sherds could not be related to known early types such as Williams Plain (Story 1965:248, 251). At Richland-Chambers Reservoir, distinctive shell-tempered sherds were recovered from contexts dated between A.D. 200 and 700 at the Adams Ranch site (McGregor and Bruseth 1987:180-181), apparently representing the earliest ceramic industry in this part of the Trinity River basin. At Lake Limestone and the J ewett Mine, a few shell-tempered sherds, a few sherds with a fine kaolin paste but no obvious temper, and larger numbers of sandy paste ceramics and grog- or bone-tempered ceramics were found in contexts that appeared to predate arrow points (i.e., the latter part of the late Archaic). While some of these could be genuinely early, especially the sandy paste wares which are so reminiscent of the early ceramics that predominate in east Texas south of the Sabine River, it is possible that the other sherds were intrusive from later deposits (Fields 1995: 308). In either case, sherds were sufficiently infrequent to suggest that, while ceramic containers may have been a notable addition to the material culture, they were not abundant. 
The most-complete picture of the archeology of the late Archaic for this region comes from the Oak Woodlands at the eastern margin of the Blackland Prairie. Along Richland and Chambers Creeks, late Archaic groups appear to have been hunter-gatherers whose subsistence pursuits focused on wild plant foods, such as hickory nuts and prairie turnip, and faunal taxa such as deer, turtles, small mammals, birds, and fish (McGregor and Bruseth 1987:236-240). While presumably not sedentary, these groups clearly used the area in an intensive fashion for residential purposes, and it appears that populations increased while territory sizes decreased. A conspicuous component of the record is the socalled "Wylie pit," examples of which were excavated at the Bird Point I sland and Adams Ranch sites. These were large features that appear to have been used for communal processing of vegetal resources (and later as cemeteries), perhaps in the context of band aggregation in "tension zones" as territories decreased in size (McGregor and Bruseth 1987:237)

The Navasota River valley and the area eastward to and across the Trinity River divide also was occupied with increased intensity during the late Archaic period (Fields 1995:307-309), although there is no evidence for the kind of population aggregations indicated at Richland-Chambers Reservoir. Faunal and macrobotanical remains were not preserved in the late Archaic components at Lake Limestone and the J ewett Mine, except for the ubiquitous hickory nutshells, and thus data on subsistence are limited. Nonetheless, it is surmised that these hunter-gatherers subsisted on a variety of wild plant foods and game, especially deer. Of the 20 excavated components assigned to this period, 15 are interpreted as residential bases and 5 as procurement/processing locations. Five of the residential-base components are located along the Navasota River and appear to represent general-purpose campsites, while the others are in the uplands to the east and consist of 2 general-purpose residential bases and 8 residential bases at which activities focused heavily on plant processing and secondarily on hunting. This distinction suggests that late Archaic settlement systems were scheduled based on the occurrence of plant foods. The analysis units interpreted as procurement/ processing locations appear to have had a primary focus on plant processing and a secondary focus on hunting-related activities. Four of these are along streams in the uplands, while the fifth is along a Navasota River tributary to the west. The data from these 20 components are consistent with the idea that late Archaic groups were chiefly foragers, as procurement/processing locations suggesting logistical use are not frequent. Settlement systems appear to have been highly scheduled, probably on a seasonal basis, with residential sites in riverine settings differing from those in the uplands. Comparisons with earlier components at Lake Limestone and the J ewett Mine are difficult, but the much greater frequency of late Archaic components and the overall greater intensity of use suggest increased population densities, decreased territories, or both. This also is suggested by the occurrence of the late Archaic cemetery at the Cottonwood Springs site along Lambs Creek on the east side of the Navasota River valley (Fields and Klement 1995).

Sites dating to the L ate Prehistoric period, after ca. A.D. 700, also are common across the central Blackland Prairie. The collections studied during the Superconducting Super Collider project contain substantial numbers of both early (e.g., Alba, Bonham, Catahoula, Colbert, Scallorn, and Steiner) and late (e.g., Cliffton and Perdiz) arrow points, but Yedlowski et al. (1998:521, 527) note that early arrow points are more frequent, perhaps reflecting continued high population densities from the late Archaic period. Other than the Perdiz and Scallorn types, which have such widespread distributions, the arrow point styles point eastward and northward. The limited ceramic samples, containing sherds reminiscent of types such as Weches Fingernail Impressed, Killough Pinched, Maydelle Incised, and Poyner Engraved, also support interaction with Caddoan groups to the east (Yedlowski et al. 1998:521-522). The Strawn Creek site at Navarro Mills Reservoir presents a similar picture, with most of the typed arrow points dating to the first half of the Late Prehistoric period and the moredistinctive ceramics in the small collection 
relating to the early Caddoan types Crockett Curvilinear Incised and Weches Fingernail Impressed (Duffield 1963). The Pecan Springs site at Bardwell Reservoir also yielded numerous early arrow points, as well as a respectable number of Perdiz points, along with a small collection of highly fragmented sherds (Sorrow 1966).

Occupations dating to the early and late parts of the Late Prehistoric period also are represented at Aquilla Lake at the western edge of the Blackland Prairie, with the strongest components at the McDonald and Brazil sites (Brown 1987:44-27). Almost all of the small ceramic sample was from one site, McDonald. Among the ceramics are specimens that could be related to the Caddoan types Canton Incised, Kiam Incised, and Maydelle Incised, pointing to interaction with groups living to the east and northeast. The faunal sample from the McDonald site indicates that these hunter-gatherers relied on deer, turtles, fish, and mussels; bison were utilized only during the latter part of the period (Brown 1987:38-144).

Hopping across the Blackland Prairie to the western edge of the Oak Woodlands, all three excavated sites at Cedar Creek Reservoir contained Late Prehistoric components, although materials of this age were common only at the Gossett Bottoms and Lacy sites (Story 1965:245-246). Early arrow point forms (e.g., Alba, Catahoula, Friley, Granbury, Scallorn, and Steiner) are better represented than late ones (e.g., Cliffton and Perdiz), but not by much. Not surprisingly, ceramics are more frequent in this area than to the west and clearly are related to the Caddoan tradition to the east and northeast; some of the more-distinctive decorated sherds were considered reminiscent of types such as Canton Incised, Killough Pinched, and Ripley or Wilder Engraved (Story 1965:226-234). The faunal remains from the Gossett Bottoms and Lacy sites, many of which probably relate to Late Prehistoric occupations, consist predominantly of deer, turtles, and small mammals, with bison occurring only in small numbers. Based on the feature evidence (or lack thereof), it appears that this part of the Trinity basin was occupied by mobile hunter-gatherers rather than sedentary groups during the Late
Prehistoric period.

As for the preceding late Archaic period, some of the best data concerning how Native Americans used the region during the Late Prehistoric period is from Richland-Chambers Reservoir and Lake Limestone and adjacent J ewett Mine. Sites dating to this interval are common at Richland-Chambers Reservoir, especially for the early half of the period, and it appears that there was a significant decline in population densities after about A.D. 1300 (McGregor and Bruseth 1987:245). The data suggest that most of the excavated sites with Late Prehistoric components were used for residential purposes (McGregor and Bruseth 1987:241, 244, 246), although there are some sites, for example the stream-side concentrations of mussel shells and artifacts at 41FT193 and 41NV139, that probably were used in a more limited fashion. The house patterns at the Bird Point Island site point to intensive use by sedentary hunter-gatherers during the first half of the period, while other components that are contemporaneous, slightly earlier, or later (e.g., at Bird Point Island, Adams Ranch, Irvine, and Little Cedar Creek) have middens and numerous features suggesting intensive use but no houses. These components may represent occupations that were seasonal in length. Macrobotanical remains point to use primarily of wild plant foods, i.e., hardwood nuts, a variety of seeds, and tubers/ rhizomes (McGregor and Bruseth 1987:243). The only tropical cultigen is maize, and it occurs in very small quantities only in contexts dating to the last half of the period. Hence, groups who lived in this area were predominantly hunters and gatherers. The arrow points that characterize the early and late parts of the period-Alba, Scallorn, and Steiner vs. Perdiz and Cliffton-are the same styles as found el sewhere across the area, and it appears that Gary dart points may have continued to be used through the early Late Prehistoric (McGregor and Bruseth 1987:183). Ceramics are moderately common and clearly relate to Caddoan wares, with most of the identified types (e.g., Maydelle Incised, Poyner Engraved, and Weches Fingernail Impressed) indicating contact with groups in the Neches River drainage, east of the Trinity.

Work at Lake Limestone along the 
Navasota River and the J ewett Mine in the uplands to the east identified 11 components dating predominantly to the Late Prehistoric period, although not all are well dated (Fields 1995:313-317). Five are interpreted as residential bases, while the other six are procurement/processing locations. These sites suggest that the Late Prehistoric period saw a change in settlement strategies from the late Archaic, and that there were changes within the Late Prehistoric period as well. During the early part of the period, residential activities were increasingly restricted to lowland sites, while the uplands were used mostly for hunting-related procurement/processing tasks. This indicates that logistical strategies became more important, but there is no evidence that this was accompanied by increased sedentism within the upper Navasota River basin itself. During the late part of the period, the area apparently saw a return to forager-oriented hunter-gatherer strategies entailing more equable use of upland and lowland settings. Faunal remains indicate that deer, turtles, and rabbits were hunted commonly, with other small mammals, bison, fish, birds, lizards, and snakes being represented as well. Hickory nutshells are by far the most common plant remains; there is no evidence for horticulture in any of these components. Scallorn and Steiner are the most common early arrow point styles, and it appears that the use of dart points may have persisted through the early part of the period (Fields 1995:314). Perdiz is the dominant late arrow point style. Ceramics occur widely but infrequently, being common only at a few sites that date mostly to the late part of the period. Nonetheless, they all relate strongly to Caddoan wares from east of the Trinity River, with the more-distinctive sherds showing typological affinities to early types such as Holly Fine Engraved and Weches Fingernail Impressed and later types such as Maydelle Incised, Killough Pinched, Poyner Engraved, and Patton Engraved. Based mostly on the abundance of Caddoan ceramics in these components, but also lack of evidence for permanent occupations (i.e., structures), Fields et al. (1991) suggested that these sites were used by Caddo Indians as base camps in support of forays by hunting parties or other procurement/processing task groups, or perhaps by groups in transit between the eastern and central parts of the state. It is equally plausible, however, that they were created by local hunter-gatherer groups and that the ceramics are the result of trade or the borrowing of ideas about ceramic manufacture and decoration. Of course, this question applies to all of the area under consideration here, given the widespread but generally low-frequency occurrence of Caddoan-style ceramics on the Blackland Prairie proper and its eastern and western edges (e.g., Brown 1987:44-29 through 44-32).

Native American archeological sites dating to the protohistoric and early historic periods are not common in the central Blackland Prairie, and it appears that much of the area was depopulated for most of this time. Materials of this age are so scarce as to be almost invisible archeologically in the project areas discussed above, i.e., the Superconducting Super Collider, Bardwell Lake, Cedar Creek Reservoir, Richland-Chambers Reservoir, Navarro Mills Reservoir, Aquilla Lake, and Lake Limestone and J ewett Mine. About the only evidence for use of these areas are occasional occurrences of Caddoan Patton Engraved sherds, potentially late shell-tempered sherds that could relate to intrusive groups from Oklahoma and north Texas, and triangular arrow points. Conspicuously present, however, is a small number of sites that relate to use by Wichita groups who moved southward into the region in the seventeenth and eighteenth centuries. Among these are the Vinson site in Limestone County, the Gas Plant site and others in the Waco area, and, just outside the region to the east, the Pearson and Gilbert sites in Rains County (Duffield and Jelks 1961; J elks 1967; Smith 1993; Story 1985b).

\section{SUMMARY OF IMPACT EVALUATIONS AND SURVEYS}

Forty-one work orders distributed across all five TxDOT Districts were completed (Figure 3). These consisted of 119 Impact Evaluations, 21 Surveys, 3 Surveys with Geoarcheological Evaluation, 1 work order for a quality control meeting with TxDOT, and 1 work order to produce this report. Combined, these work orders entailed efforts at 151 bridge or relief structure replacements, 14 projects 


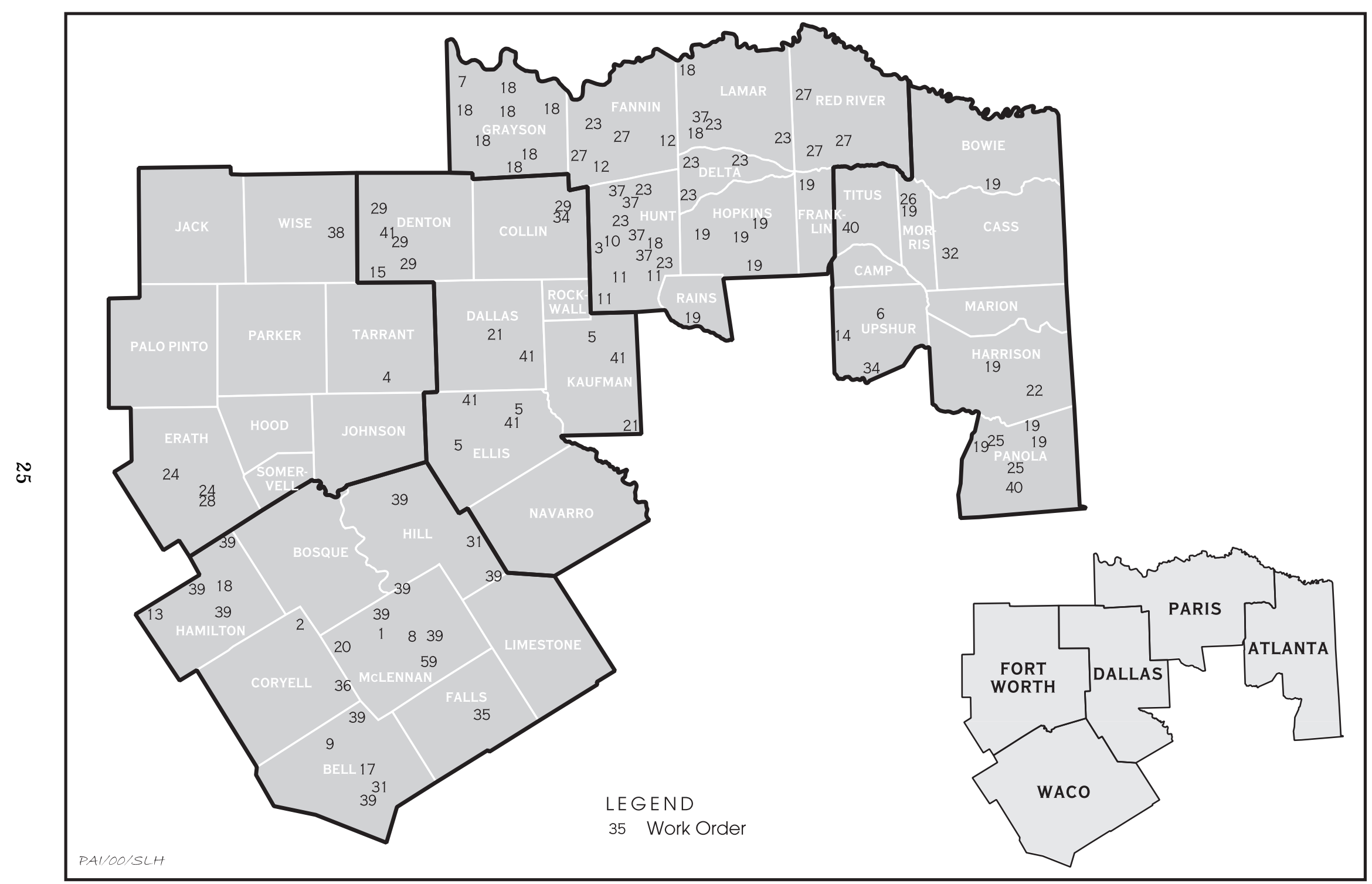

Figure 3. Map of the study area showing the locations of all I mpact Evaluations and Surveys. 
involving primarily road widening or realignment (most with bridge replacements as well), and 1 project consisting of construction of an exit ramp. During completion of these work orders, 16 newly discovered or previously recorded archeological sites and 1 possible site were investigated. This section begins with an outline of the methods used in accomplishing the work orders. Next, the work efforts are summarized in terms of distribution, setting, presence/absence of sites, and recommendations. This is followed by a discussion of the existing impacts observed as they relate to the potential for archeological remains in good context at these locations, descriptions of the sites investigated, and a summary of the results of the most-informative geoarcheological investigation. The section closes with a discussion of the utility of the fieldwork done under these work orders and recommendations for future projects of this kind.

\section{Methods}

Each work order done under this contract began with acquisition of the appropriate USGS map(s), a files search at the Texas Archeological Research Laboratory and the online Texas Archeological Sites Atlas concerning known sites in and near the project area, and review of project plans (if available) to identify impact areas. Plans showing areas to be impacted, or sufficient information to determine that no new right of way or construction easements will be required, were available for approximately 60 of the 143 areas investigated. The field methods employed varied depending on the type of project.

For I mpact Evaluations of bridge replace ments, fieldwork typically consisted of on-the ground examination of the existing right of way on both sides of the road along the full length of the project area, usually extending at least $50 \mathrm{~m}$ and sometimes several hundred meters on each side of the bridge to be replaced. As right-of-entry usually had not been obtained for known/potential impact areas beyond the existing right of way, these areas were subjected to visual inspection across fence lines. The ground surface and any disturbed areas (e.g., road cuts, the backdirt of recently placed fiber optic/telephone lines, plowed fields, etc.) within and adjacent to the existing right of way were examined for evidence of archeological remains. However, the primary thrust was to record the kinds and extent of disturbance and determine the likelihood of archeological remains in undisturbed contexts. In most cases, this entailed examining visible stream cutbanks and overall valley geometry to form an opinion about the thickness and extent of Holocene alluvium that could host buried archeological deposits. Typically, shovel tests were not dug since cutbanks provided adequate information on sediment thickness.

For each bridge replacement or other Transportation Activity, a standardized I mpact Evaluation form was completed recording anticipated impacts, location and extent of disturbances (e.g., ditches, fill sections, underground utilities, gullying/erosion, and other), location/extent of undisturbed right of way, geologic/geomorphic setting, nature/thickness/ origin of sediments, archeological remains observed, recommendations, personnel, and time spent. In addition, each project area was documented with color photographs. Impact Evaluations were done by one or two individuals, with the typical bridge replacement requiring 1-2 hours. Each of the several Impact Evaluations that involved long stretches of highway was carried out as a series of on-the-ground inspections (i.e., at each stream crossing) following the methods outlined above, with the intervening upland areas subjected to windshield inspection.

For Surveys and Surveys with Geoarcheological Evaluations, fieldwork included excavating sufficient numbers of backhoe or Gradall trenches, often accompanied by shovel tests, to constitute a good-faith effort toward determining whether archeological sites are present. As listed in Table 1, 144 trenches were excavated in 20 of the 24 survey areas, ranging from only 2 trenches to as many as 26. One hundred twenty-nine shovel tests were excavated in 14 survey areas (range $=2-48$ tests). In the 4 cases where only shovel tests were excavated, it was because the backhoe could not gain access or because of a lack of landowner permission. Only 4 of the surveys were restricted to existing rights of way; these project areas ranged from 5 to 94 acres 
Table 1. Summary of work orders

\begin{tabular}{|c|c|c|c|c|c|c|}
\hline $\begin{array}{l}\text { Work } \\
\text { Order }\end{array}$ & County & Project Type & Topographic/Geologic Setting & Land Use/Vegetation & Sites & Recommendations \\
\hline 1 & McLennan & $\begin{array}{l}\text { Impact Evaluation; } \\
\text { bridge replacement on } \\
\text { CR } 345 \text { ( } 0.4 \text { acres of new } \\
\text { ROW) }\end{array}$ & $\begin{array}{l}\text { Holocene alluvium }(1+\mathrm{m}) \text { along } \\
\text { Tennant Branch; Trinity clay soils; adja- } \\
\text { cent uplands are Cretaceous Washita } \\
\text { Group Formations }\end{array}$ & rural; adjacent lands in pasture & none & no survey needed \\
\hline 2 & Coryell & $\begin{array}{l}\text { Survey with Geoarcheo- } \\
\text { logical Assessment ( } 2 \\
\text { trenches); bridge } \\
\text { replacement on CR } 213 \\
\text { ( } 0.7 \text { acres of new ROW) }\end{array}$ & $\begin{array}{l}\text { Holocene alluvium (1.0-2.5 m) along } \\
\text { Coryell Creek; Bosque clay loam and } \\
\text { Lewisvile clay loam soils; adjacent } \\
\text { uplands are Cretaceous marl and } \\
\text { limestone }\end{array}$ & $\begin{array}{l}\text { rural; adjacent lands mostly in } \\
\text { pastures and fields }\end{array}$ & $41 C V 1620$ & no further work \\
\hline \multirow[t]{5}{*}{3} & Hunt & $\begin{array}{l}\text { Impact Evaluation; } \\
\text { bridge replacement on } \\
\text { SH } 66 \text { (specific plans not } \\
\text { available) }\end{array}$ & $\begin{array}{l}\text { Holocene alluvium }(1.5+\mathrm{m}) \text { along Payne } \\
\text { Creek; Kaufman clay soils; adjacent } \\
\text { uplands are Cretaceous Neylandville } \\
\text { and Marlbrook Marl Formations }\end{array}$ & $\begin{array}{l}\text { rural; adjacent lands mostly in } \\
\text { pastures and fields }\end{array}$ & none & no survey needed \\
\hline & Hunt & $\begin{array}{l}\text { Impact Evaluation; } \\
\text { bridge replacement on } \\
\text { SH } 66 \text { (specific plans not } \\
\text { available) }\end{array}$ & $\begin{array}{l}\text { Holocene alluvium }(3+\mathrm{m}) \text { along Brushy } \\
\text { Creek; Kaufman clay soils; adjacent } \\
\text { uplands are Cretaceous Neylandville } \\
\text { and Marlbrook Marl Formations and } \\
\text { Pleistocene terrace deposits }\end{array}$ & $\begin{array}{l}\text { rural; adjacent lands mostly in } \\
\text { pastures and fields with woods } \\
\text { along the creek }\end{array}$ & none & $\begin{array}{l}\text { survey only if impacts } \\
\text { will occur outside } \\
\text { existing ROW }\end{array}$ \\
\hline & Hunt & $\begin{array}{l}\text { Impact Evaluation; } \\
\text { bridge replacement on } \\
\text { SH } 66 \text { (specific plans not } \\
\text { available) }\end{array}$ & $\begin{array}{l}\text { Holocene alluvium }(2+\mathrm{m}) \text { along West } \\
\text { Caddo Creek slough; Kaufman clay soils; } \\
\text { adjacent uplands are Cretaceous Ney- } \\
\text { landville and Marlbrook Marl Formations } \\
\text { and Pleistocene terrace deposits }\end{array}$ & $\begin{array}{l}\text { rural; adjacent lands mostly in } \\
\text { pastures and fields with woods } \\
\text { along the creek }\end{array}$ & none & $\begin{array}{l}\text { survey only if impacts } \\
\text { will occur outside } \\
\text { existing ROW }\end{array}$ \\
\hline & Hunt & $\begin{array}{l}\text { Impact Evaluation; } \\
\text { bridge replacement on } \\
\text { SH } 66 \text { (specific plans not } \\
\text { available) }\end{array}$ & $\begin{array}{l}\text { Holocene alluvium (4+m) along West } \\
\text { Caddo Creek; Kaufman day soils; adjac- } \\
\text { ent uplands are Cretaceous Neylandville } \\
\text { and Marlbrook Marl Formations and } \\
\text { Pleistocene terrace deposits }\end{array}$ & $\begin{array}{l}\text { rural; adjacent lands mostly in } \\
\text { pastures and fields with woods } \\
\text { along the creek }\end{array}$ & none & $\begin{array}{l}\text { survey only if impacts } \\
\text { will occur outside } \\
\text { existing ROW }\end{array}$ \\
\hline & Hunt & $\begin{array}{l}\text { Impact Evaluation; } \\
\text { bridge replacement on } \\
\text { SH } 66 \text { (specific plans not } \\
\text { available) }\end{array}$ & $\begin{array}{l}\text { Holocene alluvium }(3+\mathrm{m}) \text { along West } \\
\text { Caddo Creek slough; Kaufman clay soils; } \\
\text { adjacent uplands are Cretaceous Ney- } \\
\text { landville and Marlbrook Marl Formations } \\
\text { and Pleistocene terrace deposits }\end{array}$ & $\begin{array}{l}\text { rural; adjacent lands mostly in } \\
\text { pastures and fields with woods } \\
\text { along the creek }\end{array}$ & none & $\begin{array}{l}\text { survey only if impacts } \\
\text { will occur outside } \\
\text { existing ROW }\end{array}$ \\
\hline
\end{tabular}


Table 1, continued

\begin{tabular}{|c|c|c|c|c|c|c|}
\hline $\begin{array}{l}\text { Work } \\
\text { Order }\end{array}$ & County & Project Type & Topographic/Geologic Setting & Land Use/Vegetation & Sites & Recommendations \\
\hline & Hunt & $\begin{array}{l}\text { Impact Evaluation; } \\
\text { bridge replacement on } \\
\text { SH } 66 \text { (specific plans not } \\
\text { available) }\end{array}$ & $\begin{array}{l}\text { Holocene alluvium (?? m) along West } \\
\text { Caddo Creek tributary; Leson clay soils; } \\
\text { adjacent uplands are Cretaceous Ney- } \\
\text { landville and Marlbrook Marl Formations }\end{array}$ & $\begin{array}{l}\text { rural; adjacent lands mostly in } \\
\text { pastures and fields }\end{array}$ & none & no survey needed \\
\hline & Hunt & $\begin{array}{l}\text { Impact Evaluation; } \\
\text { bridge replacement on } \\
\text { SH } 66 \text { (specific plans not } \\
\text { available) }\end{array}$ & $\begin{array}{l}\text { Holocene alluvium }(1+\mathrm{m}) \text { along EIm } \\
\text { Creek; Tinn clay soils; adjacent uplands } \\
\text { are Cretaceous Neylandville and } \\
\text { Marlbrook Marl Formations }\end{array}$ & $\begin{array}{l}\text { rural; adjacent lands mostly in } \\
\text { pastures and fields with woods } \\
\text { along the creek }\end{array}$ & none & $\begin{array}{l}\text { survey only if impacts } \\
\text { will occur outside } \\
\text { existing ROW }\end{array}$ \\
\hline & Hunt & $\begin{array}{l}\text { I mpact Evaluation; } \\
\text { bridge replacement on } \\
\text { SH } 66 \text { (specific plans not } \\
\text { available) }\end{array}$ & $\begin{array}{l}\text { Holocene alluvium }(2+\mathrm{m}) \text { along East } \\
\text { Caddo Creek slough; Tinn clay soils; } \\
\text { adjacent uplands are Cretaceous Ney- } \\
\text { landville and Marlbrook Marl F ormations } \\
\text { and Pleistocene terrace deposits }\end{array}$ & $\begin{array}{l}\text { rural; adjacent lands mostly in } \\
\text { pastures and fields with woods } \\
\text { along the creek }\end{array}$ & none & $\begin{array}{l}\text { survey only if impacts } \\
\text { will occur outside } \\
\text { existing ROW }\end{array}$ \\
\hline & Hunt & $\begin{array}{l}\text { I mpact Evaluation; } \\
\text { bridge replacement on } \\
\text { SH } 66 \text { (specific plans not } \\
\text { available) }\end{array}$ & $\begin{array}{l}\text { Holocene alluvium }(3+\mathrm{m} \text { ) along East } \\
\text { Caddo Creek; Tinn clay soils; adjacent } \\
\text { uplands are Cretaceous Neylandville } \\
\text { and Marlbrook Marl Formations and } \\
\text { Pleistocene terrace deposits }\end{array}$ & $\begin{array}{l}\text { rural; adjacent lands mostly in } \\
\text { pastures and fields with woods } \\
\text { along the creek }\end{array}$ & none & $\begin{array}{l}\text { survey only if impacts } \\
\text { will occur outside } \\
\text { existing ROW }\end{array}$ \\
\hline & Hunt & $\begin{array}{l}\text { Impact Evaluation; } \\
\text { bridge replacement on } \\
\text { SH } 66 \text { (specific plans not } \\
\text { available) }\end{array}$ & $\begin{array}{l}\text { Holocene alluvium }(1+\mathrm{m}) \text { along Block } \\
\text { Branch; Kaufman clay soils; adjacent } \\
\text { uplands are Cretaceous Neylandville } \\
\text { and Marlbrook Marl Formations and } \\
\text { Pleistocene terrace deposits }\end{array}$ & $\begin{array}{l}\text { rural; adjacent lands mostly in } \\
\text { pastures and fields }\end{array}$ & none & no survey needed \\
\hline 4 & Tarrant & $\begin{array}{l}\text { Survey ( } 4 \text { Gradall cuts); } \\
\text { construction easement } \\
\text { associated with bridge } \\
\text { replacement on Enon } \\
\text { Ave. at Everman } \\
\text { Cemetery ( } 0.2 \text { acres of } \\
\text { construction easement) }\end{array}$ & $\begin{array}{l}\text { Cretaceous Grayson Marl and Main } \\
\text { Street Limestone uplands; Crosstell fine } \\
\text { sandy loam soils }\end{array}$ & $\begin{array}{l}\text { semirural; adjacent to a modern } \\
\text { cemetery with planted grasses, } \\
\text { trees, and shrubs }\end{array}$ & none & no further work \\
\hline 5 & Ellis & $\begin{array}{l}\text { I mpact Evaluation; } \\
\text { bridge replacement on } \\
\text { FM } 66 \text { (no new ROW) }\end{array}$ & $\begin{array}{l}\text { Holocene alluvium }(2-3 \mathrm{~m} \text { ) along South } \\
\text { Prong Creek; Broken alluvial land and } \\
\text { Austin silty clay soils; adjacent uplands } \\
\text { are Cretaceous Austin Chalk }\end{array}$ & $\begin{array}{l}\text { rural; adjacent lands mostly } \\
\text { wooded }\end{array}$ & none & no survey needed \\
\hline
\end{tabular}


Table 1, continued

\begin{tabular}{|c|c|c|c|c|c|c|}
\hline $\begin{array}{l}\text { Work } \\
\text { Order }\end{array}$ & County & Project Type & Topographic/Geologic Setting & Land Use/Vegetation & Sites & Recommendations \\
\hline & Ellis & $\begin{array}{l}\text { I mpact Evaluation; } \\
\text { bridge replacement on } \\
\text { FM } 813 \text { (no new ROW) }\end{array}$ & $\begin{array}{l}\text { Holocene alluvium }(2+\mathrm{m}) \text { along Red } \\
\text { Oak Creek; Trinity clay soils; adjacent } \\
\text { uplands are Cretaceous Ozan F ormation }\end{array}$ & $\begin{array}{l}\text { rural; adjacent lands mostly in } \\
\text { pasture }\end{array}$ & none & no survey needed \\
\hline & Kaufman & $\begin{array}{l}\text { Impact Evaluation; bridge } \\
\text { replacement on Colquitt } \\
\text { Rd. (no new ROW) }\end{array}$ & $\begin{array}{l}\text { Holocene alluvium }(1+m) \text { along } \\
\text { Bachel or Creek; Kemp loam soils; } \\
\text { adjacent uplands are Cretaceous } \\
\text { Nacatoch Sand }\end{array}$ & $\begin{array}{l}\text { semirural; adjacent lands are } \\
\text { pasture and a golf course with } \\
\text { planted grasses and trees }\end{array}$ & none & no survey needed \\
\hline 6 & Upshur & $\begin{array}{l}\text { Survey ( } 9 \text { trenches, } 11 \\
\text { shovel tests); bridge and } \\
2 \text { relief structure } \\
\text { replacements on SH } 155 \\
\text { (no new ROW) }\end{array}$ & $\begin{array}{l}\text { Holocene alluvium }(1+m) \text { and terraces } \\
\text { along Little Cypress Creek; Mantachie } \\
\text { loam and Iuka fine sandy loam soils; } \\
\text { adjacent uplands are E ocene Queen City } \\
\text { Sand }\end{array}$ & $\begin{array}{l}\text { rural; adjacent lands are mostly } \\
\text { wooded with some pasture }\end{array}$ & $41 U R 28$ & no further work \\
\hline \multirow[t]{3}{*}{7} & Grayson & $\begin{array}{l}\text { Impact Evaluation; bridge } \\
\text { replacement on U.S. Hwy } \\
377 \text { (no new ROW) }\end{array}$ & $\begin{array}{l}\text { Holocene alluvium }(2-3 \mathrm{~m} \text { ) al ong Sandy } \\
\text { Creek; Bunyan soils; adjacent uplands } \\
\text { are Cretaceous Woodbine Formation }\end{array}$ & $\begin{array}{l}\text { rural; adjacent lands mostly in } \\
\text { pasture with some woods }\end{array}$ & none & no survey needed \\
\hline & Grayson & $\begin{array}{l}\text { Impact Evaluation; bridge } \\
\text { replacement on U.S. Hwy } \\
377 \text { (no new ROW) }\end{array}$ & $\begin{array}{l}\text { Holocene alluvium (2-3 m) along Brushy } \\
\text { Creek; Bunyan soils; adjacent uplands } \\
\text { are Cretaceous Woodbine F ormation }\end{array}$ & $\begin{array}{l}\text { rural; adjacent lands mostly in } \\
\text { pasture with some woods }\end{array}$ & none & no survey needed \\
\hline & Grayson & $\begin{array}{l}\text { Impact Evaluation; bridge } \\
\text { replacement on U.S. Hwy } \\
377 \text { (no new ROW) }\end{array}$ & $\begin{array}{l}\text { Holocene alluvium ( } 2-3 \mathrm{~m} \text { ) along Red } \\
\text { Branch; Bunyan soils; adjacent uplands } \\
\text { are Cretaceous Woodbine Formation }\end{array}$ & $\begin{array}{l}\text { rural; adjacent lands mostly in } \\
\text { pasture with some woods }\end{array}$ & none & no survey needed \\
\hline 8 & McLennan & $\begin{array}{l}\text { Survey with Geoarcheo- } \\
\text { logical Assessment ( } 26 \\
\text { trenches); bridge replace- } \\
\text { ment and widening of } \\
2.6 \mathrm{~km} \text { of Loop } 340 \text { (no } \\
\text { new ROW) }\end{array}$ & $\begin{array}{l}\text { Holocene alluvium }(9+m) \text { and terraces } \\
\text { and Pleistocene terraces along the Brazos } \\
\text { River; Bastrop fine sandy loam, Trinity } \\
\text { clay, Asa silt loam, Asa silty clay loam, } \\
\text { Miller day, and Yahola silt loam soils; } \\
\text { adjacent uplands are Cretaceous Ozan } \\
\text { Formation }\end{array}$ & $\begin{array}{l}\text { semirural; adjacent lands mostly } \\
\text { in pasture, fields, and borrow } \\
\text { pits }\end{array}$ & none & no further work \\
\hline 9 & Bell & $\begin{array}{l}\text { Survey ( } 5 \text { trenches); } \\
\text { bridge replacement and } \\
\text { road realignment on } \\
\text { FM } 439 \text { (13 acres of new } \\
\text { ROW) }\end{array}$ & $\begin{array}{l}\text { Holocene alluvium (1.8+m) along North } \\
\text { Nolan Creek and adjacent Cretaceous } \\
\text { Walnut Clay and Comanche Peak Lime- } \\
\text { stone uplands; Krum silty day, Lewisville } \\
\text { silty day, and Purves silty day soils }\end{array}$ & rural; mostly in pasture & $\begin{array}{l}41 B L 1099 \\
41 B L 1100 \\
41 B L 1101\end{array}$ & $\begin{array}{l}41 B L 1099 \text { is outside of } \\
\text { project area; assessment } \\
\text { of } 41 B L 1100 \text { deferred } \\
\text { pending dating of char- } \\
\text { coal sample; no further } \\
\text { work at } 41 B L 1101\end{array}$ \\
\hline
\end{tabular}


Table 1, continued

\begin{tabular}{|c|c|c|c|c|c|c|}
\hline $\begin{array}{l}\text { Work } \\
\text { Order }\end{array}$ & County & Project Type & Topographic/Geologic Setting & Land Use/Vegetation & Sites & Recommendations \\
\hline \multirow[t]{2}{*}{10} & Hunt & $\begin{array}{l}\text { Survey ( } 4 \text { trenches); } \\
\text { bridge replacement on } \\
\text { SH } 66 \text { ( } 2.8 \text { acres of new } \\
\text { ROW) }\end{array}$ & $\begin{array}{l}\text { Holocene alluvium }(2+\mathrm{m}) \text { along EIm } \\
\text { Creek; Tinn clay soils; adjacent uplands } \\
\text { are Cretaceous Neylandville and } \\
\text { Marlbrook Marl Formations }\end{array}$ & $\begin{array}{l}\text { rural; adjacent lands mostly in } \\
\text { pasture }\end{array}$ & none & no further work \\
\hline & Hunt & $\begin{array}{l}\text { Survey ( } 6 \text { trenches); } 2 \\
\text { bridge replacements on } \\
\text { SH } 66 \text { ( } 3.8 \text { acres of new } \\
\text { ROW) }\end{array}$ & $\begin{array}{l}\text { Holocene alluvium (0.7-2+m) along East } \\
\text { Caddo Creek; Tinn clay soils; adjacent } \\
\text { uplands are Cretaceous Neylandville and } \\
\text { Marlbrook Marl Formations and } \\
\text { Pleistocene terrace deposits }\end{array}$ & $\begin{array}{l}\text { rural; adjacent lands mostly in } \\
\text { pasture with woods along the } \\
\text { creek }\end{array}$ & none & no further work \\
\hline \multirow[t]{4}{*}{11} & Hunt & $\begin{array}{l}\text { Impact Evaluation; bridge } \\
\text { replacement on CR } 589 \\
\text { ( } ₫ .1 \text { acre of new ROW) }\end{array}$ & $\begin{array}{l}\text { Holocene alluvium }(2.5+\mathrm{m}) \text { al ong Pecan } \\
\text { Branch; Kaufman clay soils; adjacent } \\
\text { uplands are Cretaceous Kemp Clay }\end{array}$ & $\begin{array}{l}\text { rural; adjacent lands mostly in } \\
\text { pasture }\end{array}$ & none & no survey needed \\
\hline & Hunt & $\begin{array}{l}\text { Impact Evaluation; } \\
\text { bridge replacement on } \\
\text { CR } 793 \text { (no new ROW) }\end{array}$ & $\begin{array}{l}\text { Holocene alluvium (3-4+m) along Caddo } \\
\text { Creek; Kaufman clay soils; adjacent } \\
\text { uplands are Cretaceous Nacatoch Sand } \\
\text { and Pleistocene terrace deposits }\end{array}$ & $\begin{array}{l}\text { rural; adjacent lands mostly } \\
\text { wooded }\end{array}$ & none & no survey needed \\
\hline & Hunt & $\begin{array}{l}\text { Impact Evaluation; } \\
\text { bridge replacement on } \\
\text { CR } 813 \text { (no new ROW) }\end{array}$ & $\begin{array}{l}\text { Holocene alluvium }(2+\mathrm{m}) \text { along Dry } \\
\text { Creek and adjacent Nacatoch Sand } \\
\text { uplands; Nahatche loam soils }\end{array}$ & $\begin{array}{l}\text { rural; adjacent lands partly } \\
\text { wooded and partly in pasture }\end{array}$ & none & no survey needed \\
\hline & Hunt & $\begin{array}{l}\text { Impact Evaluation; } \\
\text { bridge replacement on } \\
\text { CR } 520 \text { (no new ROW) }\end{array}$ & $\begin{array}{l}\text { Holocene alluvium }(2+\mathrm{m}) \text { along } \\
\text { Cowleech Fork tributary; Nahatche } \\
\text { loam soils; adjacent uplands are } \\
\text { Cretaceous Navarro Group and } \\
\text { Pleistocene terrace deposits }\end{array}$ & $\begin{array}{l}\text { rural; adjacent lands mostly } \\
\text { wooded }\end{array}$ & none & no survey needed \\
\hline \multirow[t]{2}{*}{12} & Fannin & $\begin{array}{l}\text { Impact Evaluation; } \\
\text { bridge replacement on } \\
\text { FM } 1550 \text { (specific plans } \\
\text { not available) }\end{array}$ & $\begin{array}{l}\text { Holocene alluvium ( } 3-5 \mathrm{~m} \text { ) along Davis } \\
\text { Creek; Elbon silty clay loam soils; } \\
\text { adjacent uplands are Cretaceous Ozan } \\
\text { Formation }\end{array}$ & $\begin{array}{l}\text { rural; adjacent lands mostly in } \\
\text { pasture with woods along the } \\
\text { creek }\end{array}$ & none & $\begin{array}{l}\text { no survey needed } \\
\text { unless impacts extend } \\
\text { beyond existing } \\
\text { disturbed areas }\end{array}$ \\
\hline & Fannin & $\begin{array}{l}\text { Impact Evaluation; } \\
\text { bridge replacement on } \\
\text { FM } 1550 \text { (specific plans } \\
\text { not available) }\end{array}$ & $\begin{array}{l}\text { Holocene alluvium (3-5 m) along Bralley } \\
\text { Pool Creek; Elbon silty clay loam soils; } \\
\text { adjacent uplands are Cretaceous Ozan } \\
\text { Formation }\end{array}$ & $\begin{array}{l}\text { rural; adjacent lands mostly in } \\
\text { pasture with woods along the } \\
\text { creek }\end{array}$ & none & $\begin{array}{l}\text { no survey needed } \\
\text { unless impacts extend } \\
\text { beyond existing } \\
\text { disturbed areas }\end{array}$ \\
\hline
\end{tabular}


Table 1, continued

\begin{tabular}{|c|c|c|c|c|c|c|}
\hline $\begin{array}{l}\text { Work } \\
\text { Order }\end{array}$ & County & Project Type & Topographic/Geologic Setting & Land Use/Negetation & Sites & Recommendations \\
\hline & Fannin & $\begin{array}{l}\text { Impact Evaluation; } \\
\text { bridge replacement on } \\
\text { FM } 1550 \text { (specific plans } \\
\text { not available) }\end{array}$ & $\begin{array}{l}\text { Holocene alluvium }(2+m) \text { al ong Bledsoe } \\
\text { Creek; E Ibon silty clay loam soils; } \\
\text { adjacent uplands are Cretaceous Ozan } \\
\text { Formation }\end{array}$ & $\begin{array}{l}\text { rural; adjacent lands mostly in } \\
\text { pasture with woods along the } \\
\text { creek }\end{array}$ & none & $\begin{array}{l}\text { no survey needed } \\
\text { unless impacts extend } \\
\text { beyond existing } \\
\text { disturbed areas }\end{array}$ \\
\hline & Fannin & $\begin{array}{l}\text { Impact Evaluation; } \\
\text { bridge replacement on } \\
\text { FM } 1553 \text { (specific plans } \\
\text { not available) }\end{array}$ & $\begin{array}{l}\text { Holocene alluvium }(2+m) \text { along } \\
\text { Freeman Creek; Elbon-Trinity-Redlake } \\
\text { soils; adjacent uplands are Cretaceous } \\
\text { Gober Chalk }\end{array}$ & $\begin{array}{l}\text { rural; adjacent lands partly } \\
\text { wooded and partly in pasture }\end{array}$ & none & $\begin{array}{l}\text { no survey needed } \\
\text { unless impacts extend } \\
\text { beyond existing } \\
\text { disturbed areas }\end{array}$ \\
\hline \multirow[t]{2}{*}{13} & Hamilton & $\begin{array}{l}\text { Impact Evaluation (1 } \\
\text { shovel test); bridge } \\
\text { replacement on CR } 311 \\
\text { (1.3 acres of new ROW) }\end{array}$ & $\begin{array}{l}\text { Holocene alluvium }(<1 \mathrm{~m}) \text { al ong } \\
\text { Cowhouse Creek and adjacent Cretaceous } \\
\text { Paluxy Sand and Glen Rose Limestone } \\
\text { uplands; Purves-Denton-San Saba soils }\end{array}$ & $\begin{array}{l}\text { rural; adjacent lands mostly in } \\
\text { pasture and fields with woods } \\
\text { along the creek }\end{array}$ & $41 \mathrm{HM} 44$ & $\begin{array}{l}\text { no survey needed; } \\
41 \mathrm{HM} 44 \text { is outside } \\
\text { the project area }\end{array}$ \\
\hline & Hamilton & $\begin{array}{l}\text { Survey ( } 2 \text { trenches); } \\
\text { bridge replacement and } \\
\text { road realignment on CR } \\
168 \text { ( } 2 \text { acres of new ROW) }\end{array}$ & $\begin{array}{l}\text { Holocene alluvium }(2+\mathrm{m}) \text { along the Leon } \\
\text { River; Bosque clay loam soils; adjacent } \\
\text { uplands are Cretaceous Glen Rose For- } \\
\text { mation and Pleistocene terrace deposits }\end{array}$ & $\begin{array}{l}\text { rural; adjacent lands mostly in } \\
\text { pasture with woods along the } \\
\text { creek }\end{array}$ & $41 \mathrm{HM} 45$ & testing \\
\hline 14 & Upshur & $\begin{array}{l}\text { Survey ( } 6 \text { trenches, } 9 \\
\text { shovel tests); bridge } \\
\text { replacement on FM } 1002 \\
\text { ( } 1.5 \text { acres new ROW, } 0.8 \\
\text { acres for construction } \\
\text { easement) }\end{array}$ & $\begin{array}{l}\text { Holocene alluvium }(1.5+\mathrm{m}) \text { al ong Glade } \\
\text { Creek and adjacent Eocene Queen City } \\
\text { Sand uplands; I luka fine sandy loam, } \\
\text { Cuthbert fine sandy loam, and Bowie } \\
\text { fine sandy loam soils }\end{array}$ & rural; adjacent lands are wooded & 41UR36 & testing \\
\hline \multirow[t]{2}{*}{15} & Denton & $\begin{array}{l}\text { Impact Evaluation; } \\
\text { bridge replacement on } \\
\text { FM } 156 \text { (no new ROW) }\end{array}$ & $\begin{array}{l}\text { Holocene alluvium (thickness unknown ) } \\
\text { along Harriet Creek; Frio silty clay soils; } \\
\text { adjacent uplands are Cretaceous Duck } \\
\text { Creek Formation and Fort Worth } \\
\text { Limestone }\end{array}$ & $\begin{array}{l}\text { rural; adjacent lands are in } \\
\text { pasture or fields }\end{array}$ & none & no survey needed \\
\hline & Denton & $\begin{array}{l}\text { Impact Evaluation; } \\
\text { bridge replacement on } \\
\text { FM } 156 \text { (no new ROW) }\end{array}$ & $\begin{array}{l}\text { Holocene alluvium (thickness unknown) } \\
\text { and Pleistocene terrace deposits along } \\
\text { Elizabeth Creek; Frio silty clay soils; } \\
\text { adjacent uplands are Cretaceous Duck } \\
\text { Creek Formation and Fort Worth } \\
\text { Limestone }\end{array}$ & $\begin{array}{l}\text { rural; adjacent lands are in } \\
\text { pasture or fields }\end{array}$ & none & no survey needed \\
\hline 16 & - & $\begin{array}{l}\text { Quality Control } \\
\text { Debriefing with TxDOT }\end{array}$ & - & - & - & - \\
\hline
\end{tabular}


Table 1, continued

\begin{tabular}{|c|c|c|c|c|c|c|}
\hline $\begin{array}{l}\text { Work } \\
\text { Order }\end{array}$ & County & Project Type & Topographic/Geologic Setting & Land Use/Vegetation & Sites & Recommendations \\
\hline 17 & Bell & $\begin{array}{l}\text { I mpact Evaluation; } \\
\text { widening of } 7.4 \mathrm{~km} \text { of } \\
\text { Loop } 363(13.5+\text { acres of } \\
\text { new ROW) }\end{array}$ & $\begin{array}{l}\text { Cretaceous uplands (Austin Chalk, } \\
\text { Ozan, and South Bosque Formations) } \\
\text { with limited Holocene alluvium } \\
\text { (thickness unknown) along Pepper, Bird, } \\
\text { Fryars, and Boggy Creek }\end{array}$ & $\begin{array}{l}\text { mostly urban with shopping } \\
\text { centers, parking lots, etc., adjacent } \\
\text { to ROW; semirural at both ends of } \\
\text { the project area, with pastures and } \\
\text { fields adjacent to ROW }\end{array}$ & none & no survey needed \\
\hline \multirow[t]{6}{*}{18} & Grayson & $\begin{array}{l}\text { Impact Evaluation; } \\
\text { bridge replacement on } \\
\text { SH } 56 \text { (specific plans not } \\
\text { available) }\end{array}$ & $\begin{array}{l}\text { Holocene alluvium ( } 3+\mathrm{m} \text { ) along Post } \\
\text { Oak Creek; Elbon silty clay and Trinity } \\
\text { clay soils; adjacent uplands are } \\
\text { Cretaceous Austin Group and Eagle } \\
\text { Ford Formation }\end{array}$ & $\begin{array}{l}\text { urban with parking lots and } \\
\text { commercial buildings adjacent to } \\
\text { ROW }\end{array}$ & none & $\begin{array}{l}\text { no survey needed } \\
\text { unless impacts extend } \\
\text { beyond existing } \\
\text { disturbed areas; } \\
\text { historical research }\end{array}$ \\
\hline & Grayson & $\begin{array}{l}\text { Impact Evaluation; } \\
\text { bridge and relief } \\
\text { structure replacement } \\
\text { on U.S. Hwy } 82 \text { (specific } \\
\text { plans not available) }\end{array}$ & $\begin{array}{l}\text { Holocene alluvium }(2.0-2.5+\mathrm{m}) \text { along } \\
\text { Choctaw Creek; E Ibon silty clay soils; } \\
\text { adjacent uplands are Cretaceous Austin } \\
\text { Group and Eagle F ord Formation }\end{array}$ & $\begin{array}{l}\text { rural; adjacent areas are mostly } \\
\text { wooded }\end{array}$ & none & $\begin{array}{l}\text { no survey needed } \\
\text { unless impacts extend } \\
\text { beyond existing } \\
\text { disturbed areas }\end{array}$ \\
\hline & Grayson & $\begin{array}{l}\text { I mpact Evaluation; } \\
\text { bridge replacement on } \\
\text { U.S. H wy } 82 \text { (specific } \\
\text { plans not available) }\end{array}$ & $\begin{array}{l}\text { Holocene alluvium }(2-3+\mathrm{m}) \text { along Mill } \\
\text { Creek and Cretaceous Austin Chalk } \\
\text { uplands; Elbon silty clay, Whitewright- } \\
\text { Eddy-Howe, and Fairlie-Houston Black } \\
\text { clay soils }\end{array}$ & rural; adjacent lands are wooded & none & $\begin{array}{l}\text { no survey needed } \\
\text { unless impacts extend } \\
\text { beyond existing } \\
\text { disturbed areas }\end{array}$ \\
\hline & Grayson & $\begin{array}{l}\text { I mpact Evaluation; } \\
\text { bridge replacement on } \\
\text { FM } 902 \text { (specific plans } \\
\text { not available) }\end{array}$ & $\begin{array}{l}\text { Holocene alluvium }(2-3+\mathrm{m}) \text { along } \\
\text { Range Creek; EIbon silty clay soils; } \\
\text { adjacent uplands are Cretaceous Austin } \\
\text { Group and Eagle Ford Formation }\end{array}$ & $\begin{array}{l}\text { rural; adjacent lands are partly } \\
\text { wooded and partly in fields }\end{array}$ & none & $\begin{array}{l}\text { no survey needed } \\
\text { unless impacts extend } \\
\text { beyond existing } \\
\text { disturbed areas }\end{array}$ \\
\hline & Grayson & $\begin{array}{l}\text { I mpact Evaluation; } \\
\text { bridge replacement on } \\
\text { Whitaker Rd. (specific } \\
\text { plans not available) }\end{array}$ & $\begin{array}{l}\text { Holocene alluvium }(2+\mathrm{m}) \text { al ong West } \\
\text { Prong of Whites Creek and Cretaceous } \\
\text { Austin Group and Eagle Ford F ormation } \\
\text { uplands; Elbon silty clay, Austin silty } \\
\text { day, and Fairlie-Houston Black clay soils }\end{array}$ & $\begin{array}{l}\text { rural; adjacent lands are partly } \\
\text { in pasture and partly wooded }\end{array}$ & none & $\begin{array}{l}\text { no survey needed } \\
\text { unless impacts extend } \\
\text { beyond existing } \\
\text { disturbed areas }\end{array}$ \\
\hline & Grayson & $\begin{array}{l}\text { I mpact Evaluation; } \\
\text { bridge replacement on } \\
\text { CR } 194 \text { (specific plans } \\
\text { not available) }\end{array}$ & $\begin{array}{l}\text { Holocene alluvium }(1.5-2.0+\mathrm{m}) \text { al ong } \\
\text { Mustang Creek; Bunyan-Whitesboro } \\
\text { sandy loam to clay loam soils; adjacent } \\
\text { uplands are Cretaceous Woodbine For- } \\
\text { mation and Pleistocene terrace deposits }\end{array}$ & $\begin{array}{l}\text { rural; adjacent lands are partly } \\
\text { in pasture and partly wooded }\end{array}$ & none & $\begin{array}{l}\text { no survey needed } \\
\text { unless impacts extend } \\
\text { beyond existing } \\
\text { disturbed areas }\end{array}$ \\
\hline
\end{tabular}


Table 1, continued

\begin{tabular}{|c|c|c|c|c|c|c|}
\hline \multirow[t]{8}{*}{$\begin{array}{l}\text { Work } \\
\text { Order }\end{array}$} & County & Project Type & Topographic/Geologic Setting & Land Use/Vegetation & Sites & Recommendations \\
\hline & Grayson & $\begin{array}{l}\text { Impact Evaluation; } \\
\text { bridge replacement on } \mathrm{N} \text {. } \\
\text { Lincoln Park Rd. (specific } \\
\text { plans not available) }\end{array}$ & $\begin{array}{l}\text { Holocene alluvium }(2-3+\mathrm{m}) \text { al ong West } \\
\text { Prong of Sister Grove Creek; E Ibon silty } \\
\text { day soils; adjacent uplands are Cretaceous } \\
\text { Austin Group and Eagle Ford Formation }\end{array}$ & $\begin{array}{l}\text { rural; adjacent lands are partly } \\
\text { in pasture and partly wooded }\end{array}$ & none & $\begin{array}{l}\text { no survey needed } \\
\text { unless impacts extend } \\
\text { beyond existing } \\
\text { disturbed areas }\end{array}$ \\
\hline & Grayson & $\begin{array}{l}\text { I mpact Evaluation; } \\
\text { bridge replacement on } \\
\text { Whitaker Rd. (specific } \\
\text { plans not available) }\end{array}$ & $\begin{array}{l}\text { Holocene alluvium }(1.5-3.0+m) \text { al ong } \\
\text { East Prong of Whites Creek and } \\
\text { Cretaceous Austin Group and Eagle } \\
\text { Ford Formation uplands; Trinity clay, } \\
\text { Fairlie-Houston Black clay, and } \\
\text { Lewisville clay soils }\end{array}$ & $\begin{array}{l}\text { rural; adjacent lands are partly } \\
\text { in pasture and partly wooded }\end{array}$ & none & $\begin{array}{l}\text { no survey needed } \\
\text { unless impacts extend } \\
\text { beyond existing } \\
\text { disturbed areas }\end{array}$ \\
\hline & Grayson & $\begin{array}{l}\text { I mpact Evaluation; } \\
\text { bridge replacement on } \\
\text { FM } 131 \text { (specific plans } \\
\text { not available) }\end{array}$ & $\begin{array}{l}\text { Holocene alluvium }(2+\mathrm{m}) \text { along I ron } \\
\text { Ore Creek and Cretaceous Austin Group } \\
\text { and Eagle Ford Formation uplands; } \\
\text { Bunyan-Whitesboro sandy loam to clay } \\
\text { loam, Normangee clay loam, and Fairlie- } \\
\text { Houston Black clay soils }\end{array}$ & $\begin{array}{l}\text { rural; adjacent lands are partly } \\
\text { in pasture and partly wooded }\end{array}$ & none & $\begin{array}{l}\text { no survey needed } \\
\text { unless impacts extend } \\
\text { beyond existing } \\
\text { disturbed areas }\end{array}$ \\
\hline & Hunt & $\begin{array}{l}\text { Impact Evaluation; } \\
\text { bridge replacement on } \\
\text { FM } 513 \text { (specific plans } \\
\text { not available) }\end{array}$ & $\begin{array}{l}\text { Holocene alluvium (1.5-2.0+m) along } \\
\text { Caney Creek and Cretaceous Navarro } \\
\text { Group uplands; Hopco silt loam, } \\
\text { Crockett loam, Wilson silt loam, Ferris } \\
\text { clay, Leson clay, and Heiden clay soils }\end{array}$ & $\begin{array}{l}\text { rural; adjacent lands are in } \\
\text { pasture or fields and/or wooded }\end{array}$ & none & $\begin{array}{l}\text { no survey needed } \\
\text { unless impacts extend } \\
\text { onto undisturbed } \\
\text { upland edges }\end{array}$ \\
\hline & Hunt & $\begin{array}{l}\text { Impact Evaluation; } \\
\text { bridge replacement on } \\
\text { FM } 513 \text { (specific plans } \\
\text { not available) }\end{array}$ & $\begin{array}{l}\text { Holocene alluvium }(1.0-1.5+\mathrm{m}) \text { along } \\
\text { Ray Creek and Cretaceous Navarro } \\
\text { Group uplands; Hopco silt loam, } \\
\text { Crockett loam, Wilson silt loam, Ferris } \\
\text { clay, Leson clay, and Heiden clay soils }\end{array}$ & $\begin{array}{l}\text { rural; adjacent lands are in } \\
\text { pasture or fields and/or wooded }\end{array}$ & none & $\begin{array}{l}\text { no survey needed } \\
\text { unless impacts extend } \\
\text { onto undisturbed } \\
\text { upland edges }\end{array}$ \\
\hline & Hunt & $\begin{array}{l}\text { Impact Evaluation; } \\
\text { bridge replacement on } \\
\text { FM } 513 \text { (specific plans } \\
\text { not available) }\end{array}$ & $\begin{array}{l}\text { Holocene alluvium (1.0-1.5+m) along } \\
\text { Drake Creek and Cretaceous Navarro } \\
\text { Group uplands; Hopco silt loam, } \\
\text { Crockett loam, Wilson silt loam, Ferris } \\
\text { clay, Leson clay, and Heiden clay soils }\end{array}$ & $\begin{array}{l}\text { rural; adjacent lands are in } \\
\text { pasture or fields and/or wooded }\end{array}$ & none & $\begin{array}{l}\text { no survey needed } \\
\text { unless impacts extend } \\
\text { onto undisturbed } \\
\text { upland edges }\end{array}$ \\
\hline & Hunt & $\begin{array}{l}\text { Impact Evaluation; } \\
\text { bridge replacement on } \\
\text { FM } 513 \text { (specific plans } \\
\text { not available) }\end{array}$ & $\begin{array}{l}\text { Holocene alluvium }(1.5+\mathrm{m}) \text { along Head } \\
\text { Creek and Cretaceous Navarro Group } \\
\text { uplands; Hopco silt loam Crockett loam, } \\
\text { Wilson silt loam, Ferris clay, Leson clay, } \\
\text { and Heiden clay soils }\end{array}$ & $\begin{array}{l}\text { rural; adjacent lands are in } \\
\text { pasture or fields and/or wooded }\end{array}$ & none & $\begin{array}{l}\text { no survey needed } \\
\text { unless impacts extend } \\
\text { onto undisturbed } \\
\text { upland edges }\end{array}$ \\
\hline
\end{tabular}


Table 1, continued

\begin{tabular}{|c|c|c|c|c|c|c|}
\hline $\begin{array}{l}\text { Work } \\
\text { Order }\end{array}$ & County & Project Type & Topographic/Geologic Setting & Land Use/Negetation & Sites & Recommendations \\
\hline & Lamar & $\begin{array}{l}\text { I mpact Evaluation; } \\
\text { bridge replacement on } \\
\text { FM } 137 \text { (specific plans } \\
\text { not available) }\end{array}$ & $\begin{array}{l}\text { Holocene alluvium ( } 2 \mathrm{~m} \text { ) along Noble } \\
\text { Creek and Cretaceous Ozan Formation } \\
\text { uplands; Elbon silty clay, Lamar clay } \\
\text { loam, and Ferris clay soils }\end{array}$ & $\begin{array}{l}\text { rural; adjacent lands are in } \\
\text { pasture or fields and/or wooded }\end{array}$ & none & $\begin{array}{l}\text { no survey needed } \\
\text { unless impacts extend } \\
\text { beyond existing } \\
\text { disturbed areas }\end{array}$ \\
\hline & Lamar & $\begin{array}{l}\text { I mpact Evaluation; } \\
\text { bridge replacement on } \\
\text { FM } 137 \text { (specific plans } \\
\text { not available) }\end{array}$ & $\begin{array}{l}\text { Holocene alluvium ( } 3 \mathrm{~m} \text { ) along Cane } \\
\text { Creek and Cretaceous Ozan Formation } \\
\text { uplands; Trinity clay, Heiden clay, and } \\
\text { Houston Black clay soils }\end{array}$ & $\begin{array}{l}\text { semirural; adjacent lands are in } \\
\text { pasture or fields and residential } \\
\text { areas }\end{array}$ & none & $\begin{array}{l}\text { no survey needed } \\
\text { unless impacts extend } \\
\text { beyond existing } \\
\text { disturbed areas }\end{array}$ \\
\hline & Lamar & $\begin{array}{l}\text { I mpact Evaluation; } \\
\text { bridge replacement on } \\
\text { FM } 137 \text { (specific plans } \\
\text { not available) }\end{array}$ & $\begin{array}{l}\text { Holocene alluvium ( } 3 \mathrm{~m} \text { ) along Maxwell } \\
\text { Creek; Trinity clay and Houston Black } \\
\text { clay soils; adjacent uplands are } \\
\text { Cretaceous Ozan Formation }\end{array}$ & $\begin{array}{l}\text { rural; adjacent lands are in } \\
\text { pasture or fields and/or wooded }\end{array}$ & none & $\begin{array}{l}\text { no survey needed } \\
\text { unless impacts extend } \\
\text { beyond existing } \\
\text { disturbed areas }\end{array}$ \\
\hline & Lamar & $\begin{array}{l}\text { Impact Evaluation; } \\
\text { bridge replacement on } \\
\text { FM } 79 \text { (specific plans not } \\
\text { available) }\end{array}$ & $\begin{array}{l}\text { Holocene alluvium }(2.5+\mathrm{m}) \text { along Slough } \\
\text { Creek and Pleistocene terrace uplands; } \\
\text { Desha clay, Woodtell loam, and } \\
\text { Whakana-Porum loamy soils }\end{array}$ & rural; adjacent lands are wooded & none & $\begin{array}{l}\text { no survey needed } \\
\text { unless impacts extend } \\
\text { beyond existing } \\
\text { disturbed areas }\end{array}$ \\
\hline & Lamar & $\begin{array}{l}\text { I mpact Evaluation; } \\
\text { bridge and relief } \\
\text { structure replacement } \\
\text { on FM } 79 \text { (specific plans } \\
\text { not available) }\end{array}$ & $\begin{array}{l}\text { Holocene alluvium (1.5-2.0+m) along } \\
\text { Sanders Creek and Cretaceous Eagle } \\
\text { Ford Formation uplands; Roxton clay, } \\
\text { Annona loam, and Whakana-Porum } \\
\text { loamy soils }\end{array}$ & $\begin{array}{l}\text { rural; adjacent lands are in } \\
\text { pasture or fields and/or wooded }\end{array}$ & none & $\begin{array}{l}\text { no survey needed } \\
\text { unless impacts extend } \\
\text { beyond existing } \\
\text { disturbed areas }\end{array}$ \\
\hline \multirow[t]{4}{*}{19} & Bowie & $\begin{array}{l}\text { Survey ( } 4 \text { shovel tests); } \\
\text { widening of } 0.4 \mathrm{~km} \text { of } \\
\text { SH } 8 \text { (no new ROW) }\end{array}$ & $\begin{array}{l}\text { Eocene Wilcox Group uplands; Bryarly } \\
\text { clay loam and Woodtell very fine sandy } \\
\text { loam soils }\end{array}$ & $\begin{array}{l}\text { semirural; adjacent lands are } \\
\text { partly a devel oped park and } \\
\text { partly wooded }\end{array}$ & none & no further work \\
\hline & Franklin & $\begin{array}{l}\text { Impact Evaluation; } \\
\text { bridge replacement on } \\
\text { CR } 130 \text { (specific plans } \\
\text { not available) }\end{array}$ & $\begin{array}{l}\text { Holocene alluvium }(1.0-1.5+m) \text { al ong } \\
\text { Cobb J ones Creek and Paleocene } \\
\text { Midway Group uplands; Nahatche clay } \\
\text { loam and Woodtell-Raino loamy soils }\end{array}$ & rural; adjacent lands are wooded & none & $\begin{array}{l}\text { no survey needed } \\
\text { unless impacts extend } \\
\text { beyond existing } \\
\text { disturbed areas }\end{array}$ \\
\hline & Harrison & $\begin{array}{l}\text { I mpact Evaluation; } \\
\text { widening of } 1.2 \mathrm{~km} \text { of } \\
\text { SH } 154 \text { (specific plans } \\
\text { not available) }\end{array}$ & $\begin{array}{l}\text { Eocene Recklaw Formation uplands; } \\
\text { Bernaldo, Cuthbert, Kirvin, and Sacul } \\
\text { fine sandy loam soils }\end{array}$ & $\begin{array}{l}\text { semiurban; adjacent lands are } \\
\text { wooded or residential areas }\end{array}$ & none & $\begin{array}{l}\text { no survey needed } \\
\text { unless impacts extend } \\
\text { beyond existing } \\
\text { disturbed areas }\end{array}$ \\
\hline & Hopkins & $\begin{array}{l}\text { Impact Evaluation; bridge } \\
\text { and } 3 \text { relief structure } \\
\text { replacements on IH } 30\end{array}$ & $\begin{array}{l}\text { Holocene alluvium }(1-2+\mathrm{m}) \text { al ong Rock } \\
\text { Creek; Nahatche clay loam soils; } \\
\text { adjacent uplands are Eocene Wilcox and }\end{array}$ & $\begin{array}{l}\text { rural; adjacent lands are wooded } \\
\text { to the north, IH } 30 \text { to the south }\end{array}$ & none & no survey needed \\
\hline
\end{tabular}


Table 1, continued

\begin{tabular}{|c|c|c|c|c|c|c|}
\hline $\begin{array}{l}\text { Work } \\
\text { Order }\end{array}$ & County & Project Type & Topographic/Geologic Setting & Land Use/Vegetation & Sites & Recommendations \\
\hline & $\begin{array}{l}\text { Hopkins, } \\
\text { continued }\end{array}$ & $\begin{array}{l}\text { frontage road (specific } \\
\text { plans not available) }\end{array}$ & Midway Groups & & & \\
\hline & Hopkins & $\begin{array}{l}\text { I mpact Evaluation; bridge } \\
\text { replacement on IH } 30 \\
\text { frontage road ( } 1.4 \text { acres of } \\
\text { new ROW, } 2.3 \text { acres for } \\
\text { construction easements) }\end{array}$ & $\begin{array}{l}\text { Holocene alluvium }(2+\mathrm{m}) \text { along E ast } \\
\text { Caney Creek; Nahatche clay loam soils; } \\
\text { adjacent uplands are Eocene Wilcox and } \\
\text { Midway Groups }\end{array}$ & $\begin{array}{l}\text { rural; adjacent lands are wooded } \\
\text { to the north, IH } 30 \text { to the south }\end{array}$ & none & no survey needed \\
\hline & Hopkins & $\begin{array}{l}\text { Impact Evaluation; } \\
\text { bridge replacement on } \\
\text { CR } 596 \text { (specific plans } \\
\text { not available) }\end{array}$ & $\begin{array}{l}\text { Holocene alluvium }(3+m) \text { al ong White } \\
\text { Oak Creek and Eocene Wilcox and } \\
\text { Midway Group uplands; Nahatche clay } \\
\text { loam and Crockett loam soils }\end{array}$ & $\begin{array}{l}\text { rural; adjacent lands are partly } \\
\text { in pasture and partly wooded }\end{array}$ & none & $\begin{array}{l}\text { no survey needed } \\
\text { unless impacts extend } \\
\text { beyond existing } \\
\text { disturbed areas }\end{array}$ \\
\hline & Hopkins & $\begin{array}{l}\text { Impact Evaluation; } 2 \\
\text { bridge replacements on } \\
\text { CR } 572 \text { (specific plans } \\
\text { not available) }\end{array}$ & $\begin{array}{l}\text { Holocene alluvium }(1.0-1.5+m) \text { along } \\
\text { Kennedy Creek and Eocene Wilcox and } \\
\text { Midway Group uplands; Nahatche clay } \\
\text { loam and Freestone loam soils }\end{array}$ & $\begin{array}{l}\text { rural; adjacent lands are partly } \\
\text { in pasture and partly wooded }\end{array}$ & none & $\begin{array}{l}\text { no survey needed } \\
\text { unless impacts extend } \\
\text { beyond existing } \\
\text { disturbed areas }\end{array}$ \\
\hline & Hopkins & $\begin{array}{l}\text { Impact Evaluation; } \\
\text { bridge replacement on } \\
\text { CR } 271 \text { (specific plans } \\
\text { not available) }\end{array}$ & $\begin{array}{l}\text { Holocene alluvium }(1+\mathrm{m}) \text { al ong Running } \\
\text { Creek and Eocene Wilcox and Midway } \\
\text { Group uplands; Nahatche clay loam and } \\
\text { Freestone and Woodtell loam soils }\end{array}$ & rural; adjacent lands are wooded & none & $\begin{array}{l}\text { no survey needed } \\
\text { unless impacts extend } \\
\text { beyond existing } \\
\text { disturbed areas }\end{array}$ \\
\hline & Hopkins & $\begin{array}{l}\text { Impact Evaluation; } \\
\text { bridge replacement on } \\
\text { CR } 387 \text { (specific plans } \\
\text { not available) }\end{array}$ & $\begin{array}{l}\text { Holocene alluvium }(1.5+\mathrm{m}) \text { al ong Glade } \\
\text { Creek and E ocene Wilcox and Midway } \\
\text { Group uplands; Nahatche clay loam and } \\
\text { Freestone and Woodtell loam soils }\end{array}$ & $\begin{array}{l}\text { rural; adjacent lands are partly } \\
\text { in pasture and partly wooded }\end{array}$ & none & $\begin{array}{l}\text { no survey needed } \\
\text { unless impacts extend } \\
\text { beyond existing } \\
\text { disturbed areas }\end{array}$ \\
\hline & Morris & $\begin{array}{l}\text { Impact Evaluation; bridge } \\
\text { and relief structure } \\
\text { replacements and road } \\
\text { realignment on FM } 144 \\
\text { (4.4 acres of new ROW) }\end{array}$ & $\begin{array}{l}\text { Holocene alluvium }(1-2+m) \text { along } \\
\text { Boggy Creek and upland E ocene } \\
\text { Recklaw Formation; Nahatche clay } \\
\text { loam, Liberty loamy fine sand, and } \\
\text { Cuthbert fine sandy loam }\end{array}$ & $\begin{array}{l}\text { rural; adjacent lands are partly } \\
\text { in pasture and partly wooded }\end{array}$ & none & survey new ROW \\
\hline & Panola & $\begin{array}{l}\text { I mpact Evaluation; } 2 \\
\text { bridge replacements and } \\
\text { widening of } 3 \mathrm{~km} \text { of U.S. } \\
\text { Hwy } 79 \text { (no new ROW) }\end{array}$ & $\begin{array}{l}\text { Holocene alluvium }(1.5+\mathrm{m}) \text { along the } \\
\text { Sabine River and Pleistocene terrace } \\
\text { deposits; Urbo-Mantachie clay to clay } \\
\text { loam and Cart-E rno sandy clay loam } \\
\text { soils; adjacent uplands are Eocene } \\
\text { Wilcox Group }\end{array}$ & rural; adjacent lands are wooded & none & no survey needed \\
\hline
\end{tabular}


Table 1, continued

\begin{tabular}{|c|c|c|c|c|c|c|}
\hline $\begin{array}{l}\text { Work } \\
\text { Order }\end{array}$ & County & Project Type & Topographic/Geologic Setting & Land Use/Vegetation & Sites & Recommendations \\
\hline & Panola & $\begin{array}{l}\text { I mpact Evaluation; } \\
\text { bridge replacement on } \\
\text { FM } 1186 \text { (specific plans } \\
\text { not available) }\end{array}$ & $\begin{array}{l}\text { Holocene alluvium }(0.5+\mathrm{m}) \text { al ong } \\
\text { J ackson Creek and E ocene Wilcox Group } \\
\text { uplands; Nahatche clay loam and Sacul } \\
\text { fine sandy loam soils }\end{array}$ & rural; adjacent lands are wooded & none & $\begin{array}{l}\text { no survey needed } \\
\text { unless impacts extend } \\
\text { beyond existing } \\
\text { disturbed areas }\end{array}$ \\
\hline & Panola & $\begin{array}{l}\text { I mpact Evaluation; bridge } \\
\text { replacement on FM } 124 \\
\text { ( } 2.8 \text { acres of new ROW) }\end{array}$ & $\begin{array}{l}\text { Holocene alluvium }(2+\mathrm{m}) \text { al ong Buckner } \\
\text { Creek; Nahatche clay loam soils; adjacent } \\
\text { uplands are Eocene Wilcox Group }\end{array}$ & $\begin{array}{l}\text { rural; adjacent lands are partly } \\
\text { in pasture and partly wooded }\end{array}$ & none & survey new ROW \\
\hline & Panola & $\begin{array}{l}\text { I mpact Evaluation; } \\
\text { bridge replacement on } \\
\text { FM } 124 \text { ( } 3.7 \text { acres of new } \\
\text { ROW and construction } \\
\text { easements) }\end{array}$ & $\begin{array}{l}\text { Holocene alluvium }(1.5+\mathrm{m}) \text { along Caney } \\
\text { Creek; Nahatche clay loam soils; } \\
\text { adjacent uplands are E ocene Wilcox } \\
\text { Group }\end{array}$ & $\begin{array}{l}\text { rural; adjacent lands are partly } \\
\text { in pasture and partly wooded }\end{array}$ & none & survey new ROW \\
\hline & Rains & $\begin{array}{l}\text { Impact Evaluation ( } 3 \\
\text { shovel tests); bridge and } \\
2 \text { relief structure replace- } \\
\text { ments on SH } 19 \text { (specific } \\
\text { plans not available) }\end{array}$ & $\begin{array}{l}\text { Holocene alluvium }(1.5+m) \text { along the } \\
\text { Sabine River and E ocene Wilcox Group } \\
\text { uplands; Gladewater clay and Woodtell } \\
\text { loam soils }\end{array}$ & rural; adjacent lands are wooded & 41RA86 & $\begin{array}{l}\text { no survey needed } \\
\text { unless impacts extend } \\
\text { beyond existing } \\
\text { disturbed areas; no } \\
\text { further work at 41RA86 }\end{array}$ \\
\hline 20 & McLennan & $\begin{array}{l}\text { I mpact Evaluation; } \\
\text { bridge replacement on } \\
\text { SH } 317 \text { (no new ROW) }\end{array}$ & $\begin{array}{l}\text { Holocene alluvium ( }<0.5 \mathrm{~m} \text { ) along Wasp } \\
\text { Creek; Trinity clay soils; adjacent } \\
\text { uplands are Cretaceous Washita Group }\end{array}$ & $\begin{array}{l}\text { rural; adjacent lands are mostly } \\
\text { in pasture }\end{array}$ & none & no survey needed \\
\hline \multirow[t]{2}{*}{21} & Dallas & $\begin{array}{l}\text { Impact Evaluation; exit } \\
\text { ramp construction on } \\
\text { Preston Road (no new } \\
\text { ROW) }\end{array}$ & $\begin{array}{l}\text { Holocene alluvium ( } 3 \mathrm{~m} \text { ) along White } \\
\text { Rock Creek; Eddy-Urban and Frio- } \\
\text { Urban Iand complex soils; adjacent } \\
\text { uplands are Cretaceous Austin Chalk }\end{array}$ & urban & none & no survey needed \\
\hline & Kaufman & $\begin{array}{l}\text { I mpact Evaluation; } 4 \\
\text { bridge replacements on } \\
\text { U.S. H wy } 175 \text { (no new } \\
\text { ROW) }\end{array}$ & $\begin{array}{l}\text { Man-made causeway on Holocene } \\
\text { alluvium and Pleistocene terrace } \\
\text { deposits at Cedar Creek Reservoir; } \\
\text { Lufkin-Rader complex soils }\end{array}$ & mostly a man-made causeway & $\begin{array}{l}\text { none in } \\
\text { project area; } \\
41 \text { KF } 83 \text { and } \\
41 \text { KF } 84 \\
\text { noted nearby }\end{array}$ & no survey needed \\
\hline 22 & Harrison & $\begin{array}{l}\text { Impact Evaluation; } \\
\text { rehabilitation of } 10.9 \mathrm{~km} \\
\text { of road and bridge and } \\
\text { relief structure } \\
\text { replacements on FM } 31 \\
\text { (no new ROW) }\end{array}$ & $\begin{array}{l}\text { Eocene Wilcox Group uplands and Holo- } \\
\text { cene alluvium (1-2+m) and Pleistocene } \\
\text { terrace deposits along Quapaw Creek; } \\
\text { Scottsville very fine sandy loam, Bernaldo } \\
\text { and Latex fine sandy loam, and Sardis- } \\
\text { Mathiston complex soils }\end{array}$ & $\begin{array}{l}\text { rural; adjacent lands are partly } \\
\text { in pasture and partly wooded }\end{array}$ & none & no survey needed \\
\hline
\end{tabular}


Table 1, continued

\begin{tabular}{|c|c|c|c|c|c|c|}
\hline $\begin{array}{l}\text { Work } \\
\text { Order }\end{array}$ & County & Project Type & Topographic/Geologic Setting & Land Use/Vegetation & Sites & Recommendations \\
\hline \multirow[t]{8}{*}{23} & Delta & $\begin{array}{l}\text { I mpact Evaluation; } \\
\text { bridge replacement on } \\
\text { CR } 106 \text { (specific plans } \\
\text { not available) }\end{array}$ & $\begin{array}{l}\text { Holocene alluvium }(2+\mathrm{m}) \text { along J ohns } \\
\text { Creek and Cretaceous Marlbrook Marl } \\
\text { uplands; Trinity clay and Houston Black } \\
\text { clay soils }\end{array}$ & $\begin{array}{l}\text { rural; adjacent lands are mostly } \\
\text { in pasture }\end{array}$ & none & $\begin{array}{l}\text { no survey needed } \\
\text { unless impacts extend } \\
\text { beyond existing } \\
\text { disturbed areas }\end{array}$ \\
\hline & Delta & $\begin{array}{l}\text { Impact Evaluation; } \\
\text { bridge replacement on } \\
\text { CR } 128 \text { (specific plans } \\
\text { not available) }\end{array}$ & $\begin{array}{l}\text { Holocene alluvium }(2+m) \text { along West } \\
\text { Fork of J ernigan Creek; Trinity clay and } \\
\text { Wilson silt loam soils; adjacent uplands } \\
\text { are Cretaceous Marlbrook Marl }\end{array}$ & rural; adjacent lands are wooded & none & $\begin{array}{l}\text { no survey needed } \\
\text { unless impacts extend } \\
\text { beyond existing } \\
\text { disturbed areas }\end{array}$ \\
\hline & Delta & $\begin{array}{l}\text { Impact Evaluation; } \\
\text { bridge replacement on } \\
\text { CR } 218 \text { (specific plans } \\
\text { not available) }\end{array}$ & $\begin{array}{l}\text { Holocene alluvium (2.0-2.5+m) along } \\
\text { Lake Creek; Kaufman clay and Wilson } \\
\text { silt loam soils; adjacent uplands are } \\
\text { Cretaceous Marlbrook Marl }\end{array}$ & $\begin{array}{l}\text { rural; adjacent lands are partly } \\
\text { in pasture and partly wooded }\end{array}$ & none & $\begin{array}{l}\text { no survey needed } \\
\text { unless impacts extend } \\
\text { beyond existing } \\
\text { disturbed areas }\end{array}$ \\
\hline & Delta & $\begin{array}{l}\text { Impact Evaluation; } \\
\text { bridge replacement on } \\
\text { CR } 180 \text { (specific plans } \\
\text { not available) }\end{array}$ & $\begin{array}{l}\text { Holocene alluvium }(2+m) \text { and Pleistocene } \\
\text { terrace deposits along a tributary of the } \\
\text { North Sulphur River; Wilson and Benklin } \\
\text { silt loam soils; adjacent uplands are } \\
\text { Cretaceous Wolf City, Ozan, and Pecan } \\
\text { Gap Chalk Formations }\end{array}$ & $\begin{array}{l}\text { rural; adjacent lands are partly } \\
\text { wooded and partly in fields }\end{array}$ & none & $\begin{array}{l}\text { no survey needed } \\
\text { unless impacts extend } \\
\text { beyond existing } \\
\text { disturbed areas }\end{array}$ \\
\hline & Fannin & $\begin{array}{l}\text { Impact Evaluation; } \\
\text { bridge replacement on } \\
\text { U.S. H wy } 82 \text { (specific } \\
\text { plans not available) }\end{array}$ & $\begin{array}{l}\text { Holocene alluvium }(2.0-2.5+\mathrm{m}) \text { along } \\
\text { Big Caney Creek; Elbon-Trinity-Redlake } \\
\text { complex soils; adjacent uplands are } \\
\text { Cretaceous Eagle Ford Formation }\end{array}$ & rural; adjacent lands are wooded & none & $\begin{array}{l}\text { no survey needed } \\
\text { unless impacts extend } \\
\text { beyond existing } \\
\text { disturbed areas }\end{array}$ \\
\hline & Hunt & $\begin{array}{l}\text { Impact Evaluation; } \\
\text { bridge replacement on } \\
\text { CR } 1035 \text { (specific plans } \\
\text { not available) }\end{array}$ & $\begin{array}{l}\text { Holocene alluvium }(2.5+m) \text { along Hickory } \\
\text { Creek and Pleistocene terrace deposits; } \\
\text { Hopco silt loam and Axtell loam soils; } \\
\text { adjacent uplands are Pecan Gap Chalk }\end{array}$ & rural; adjacent lands are wooded & none & $\begin{array}{l}\text { no survey needed } \\
\text { unless impacts extend } \\
\text { beyond existing } \\
\text { disturbed areas }\end{array}$ \\
\hline & Hunt & $\begin{array}{l}\text { Impact Evaluation; } \\
\text { bridge replacement on } \\
\text { CR } 1032 \text { (specific plans } \\
\text { not available) }\end{array}$ & $\begin{array}{l}\text { Holocene alluvium ( } 1.5+\mathrm{m}) \text { along a } \\
\text { tributary of Cowleech Fork and } \\
\text { Pleistocene terrace deposits; Tinn clay } \\
\text { and Crockett loam soils; adjacent } \\
\text { uplands are Cretaceous Marlbrook Marl }\end{array}$ & $\begin{array}{l}\text { rural; adjacent lands are partly } \\
\text { in pasture and partly wooded }\end{array}$ & none & $\begin{array}{l}\text { no survey needed } \\
\text { unless impacts extend } \\
\text { beyond existing } \\
\text { disturbed areas }\end{array}$ \\
\hline & Hunt & $\begin{array}{l}\text { Impact Evaluation; } \\
\text { culvert replacement on } \\
\text { CR } 3211 \text { (specific plans } \\
\text { not available) }\end{array}$ & $\begin{array}{l}\text { Holocene alluvium }(1.5+m) \text { along Lake } \\
\text { Fork Creek and Paleocene Kincaid } \\
\text { Formation uplands; Hopco silt loam and } \\
\text { Crockett loam soils }\end{array}$ & rural; adjacent lands are wooded & none & $\begin{array}{l}\text { no survey needed } \\
\text { unless impacts extend } \\
\text { beyond existing } \\
\text { disturbed areas }\end{array}$ \\
\hline
\end{tabular}


Table 1, continued

\begin{tabular}{|c|c|c|c|c|c|c|}
\hline $\begin{array}{l}\text { Work } \\
\text { Order }\end{array}$ & County & Project Type & Topographic/Geologic Setting & Land Use/Vegetation & Sites & Recommendations \\
\hline & Hunt & $\begin{array}{l}\text { Impact Evaluation; } \\
\text { bridge replacement on } \\
\text { FM } 1563 \text { (specific plans } \\
\text { not available) }\end{array}$ & $\begin{array}{l}\text { Holocene alluvium }(2+m) \text { along the } \\
\text { Middle Sulphur River and Cretaceous } \\
\text { Wolf City and Pecan Gap Chalk } \\
\text { Formation uplands; Hopco silt loam and } \\
\text { Crockett loam soils }\end{array}$ & $\begin{array}{l}\text { rural; adjacent lands are partly } \\
\text { wooded and partly in pasture }\end{array}$ & none & $\begin{array}{l}\text { no survey needed } \\
\text { unless impacts extend } \\
\text { beyond existing } \\
\text { disturbed areas }\end{array}$ \\
\hline & Lamar & $\begin{array}{l}\text { I mpact Evaluation; } \\
\text { bridge replacement on } \\
\text { 2nd St. (specific plans } \\
\text { not available) }\end{array}$ & $\begin{array}{l}\text { Holocene alluvium }(2+m) \text { along Cane } \\
\text { Creek and Cretaceous Ozan Formation } \\
\text { uplands; Trinity clay, Heiden clay, and } \\
\text { Norwood silt loam soils }\end{array}$ & $\begin{array}{l}\text { urban; adjacent lands contain } \\
\text { residential and commercial } \\
\text { developments }\end{array}$ & none & $\begin{array}{l}\text { no survey needed } \\
\text { unless impacts extend } \\
\text { beyond existing } \\
\text { disturbed areas }\end{array}$ \\
\hline & Lamar & $\begin{array}{l}\text { I mpact Evaluation; } \\
\text { bridge replacement on } \\
\text { Deport St. (specific plans } \\
\text { not available) }\end{array}$ & $\begin{array}{l}\text { Holocene alluvium }(2+\mathrm{m}) \text { along } \\
\text { Mustang Creek and Cretaceous Pecan } \\
\text { Gap Chalk uplands; Lassiter silt loam } \\
\text { and Wilson silt loam soils }\end{array}$ & $\begin{array}{l}\text { urban; adjacent lands contain } \\
\text { residential and commercial } \\
\text { developments }\end{array}$ & none & $\begin{array}{l}\text { no survey needed } \\
\text { unless impacts extend } \\
\text { beyond existing } \\
\text { disturbed areas }\end{array}$ \\
\hline \multirow[t]{2}{*}{24} & Erath & $\begin{array}{l}\text { Impact Evaluation; } \\
\text { bridge replacement on } \\
\text { CR } 417 \text { ( } 0.3 \text { acres of new } \\
\text { ROW) }\end{array}$ & $\begin{array}{l}\text { Holocene alluvium }(3.5+\mathrm{m}) \text { along a } \\
\text { tributary of the South Fork of the North } \\
\text { Bosque River; Bunyan fine sandy loam } \\
\text { soils; adjacent uplands are Cretaceous } \\
\text { Paluxy and Glen Rose Formations }\end{array}$ & $\begin{array}{l}\text { rural; adjacent lands are partly } \\
\text { in pasture or fields and partly } \\
\text { wooded }\end{array}$ & none & survey new ROW \\
\hline & Erath & $\begin{array}{l}\text { Impact Evaluation; } \\
\text { bridge replacement on } \\
\text { CR } 230 \text { ( } 0.5 \text { acres of new } \\
\text { ROW and construction } \\
\text { easements) }\end{array}$ & $\begin{array}{l}\text { Holocene alluvium ( } 3-4 \mathrm{~m} \text { ) along a } \\
\text { tributary of Duffau Creek and Cretaceous } \\
\text { Paluxy and Walnut Formation uplands; } \\
\text { Frio clay loam, Purves-Dugout complex, } \\
\text { and Duffau fine sandy loam soils }\end{array}$ & $\begin{array}{l}\text { rural; adjacent lands are partly } \\
\text { in pasture and partly wooded }\end{array}$ & none & $\begin{array}{l}\text { survey new } \\
\text { ROW/construction } \\
\text { easements west of } \\
\text { creek }\end{array}$ \\
\hline \multirow[t]{2}{*}{25} & Panola & $\begin{array}{l}\text { Survey ( } 12 \text { trenches, } 2 \\
\text { shovel tests); bridge } \\
\text { replacement and road } \\
\text { realignment on FM } 124 \\
\text { ( } 2.8 \text { acres of new ROW) }\end{array}$ & $\begin{array}{l}\text { Holocene alluvium }(2+\mathrm{m}) \text { al ong Buckner } \\
\text { Creek; Nahatche clay loam and Thenas } \\
\text { fine sandy loam to clay loam soils; } \\
\text { adjacent uplands are E ocene Wilcox } \\
\text { Group }\end{array}$ & $\begin{array}{l}\text { rural; adjacent lands are partly } \\
\text { in pasture and partly wooded }\end{array}$ & none & no further work \\
\hline & Panola & $\begin{array}{l}\text { Survey ( } 15 \text { trenches, } 2 \\
\text { shovel tests); bridge } \\
\text { replacement on FM } 124 \\
\text { ( } 3.7 \text { acres of new ROW and } \\
\text { construction easements) }\end{array}$ & $\begin{array}{l}\text { Holocene alluvium }(2+m) \text { along Caney } \\
\text { Creek and Eocene Wilcox Group } \\
\text { uplands; Nahatche clay loam and Sacul } \\
\text { fine sandy loam soils }\end{array}$ & $\begin{array}{l}\text { rural; adjacent lands are partly } \\
\text { in pasture and partly wooded }\end{array}$ & none & no further work \\
\hline
\end{tabular}


Table 1, continued

\begin{tabular}{|c|c|c|c|c|c|c|}
\hline $\begin{array}{l}\text { Work } \\
\text { Order }\end{array}$ & County & Project Type & Topographic/Geologic Setting & Land Use/Vegetation & Sites & Recommendations \\
\hline & Panola & $\begin{array}{l}\text { Survey ( } 7 \text { trenches, } 6 \\
\text { shovel tests); bridge } \\
\text { replacement and road } \\
\text { realignment on FM } 10 \text { ( } 6.2 \\
\text { acres of new ROW and } \\
\text { construction easements) }\end{array}$ & $\begin{array}{l}\text { Holocene alluvium }(2+\mathrm{m}) \text { along Six Mile } \\
\text { Creek and Eocene Wilcox Group } \\
\text { uplands; Nahatche clay loam, } \\
\text { Wrightville-Cart complex, and Sacul } \\
\text { fine sandy loam soils }\end{array}$ & $\begin{array}{l}\text { rural; adjacent lands are partly } \\
\text { in pasture, partly wooded, and } \\
\text { partly in recently clear-cut area }\end{array}$ & none & no further work \\
\hline 26 & Morris & $\begin{array}{l}\text { Survey ( } 5 \text { trenches, } 4 \\
\text { shovel tests); bridge and } \\
\text { relief structure } \\
\text { replacement and road } \\
\text { realignment on FM } 144 \\
\text { (4.4 acres of new ROW) }\end{array}$ & $\begin{array}{l}\text { Holocene alluvium (1-2 m) along Boggy } \\
\text { Creek and E ocene Reklaw Formation } \\
\text { uplands; Nahatche clay loam, Liberty } \\
\text { loamy fine sand, and Cuthbert fine } \\
\text { sandy loam soils }\end{array}$ & $\begin{array}{l}\text { rural; adjacent lands are mostly } \\
\text { in pasture }\end{array}$ & none & no further work \\
\hline \multirow[t]{5}{*}{27} & Fannin & $\begin{array}{l}\text { Impact Evaluation; } \\
\text { bridge replacement on } \\
\text { CR } 271 \text { (specific plans } \\
\text { not available) }\end{array}$ & $\begin{array}{l}\text { Holocene alluvium }(2+\mathrm{m}) \text { along Cooper } \\
\text { Creek and Cretaceous Bonham Marl } \\
\text { uplands; Elbon silty clay loam, Lassiter } \\
\text { silt loam, and Wilson-Normangee- } \\
\text { Crockett soils }\end{array}$ & $\begin{array}{l}\text { rural; adjacent lands are partly } \\
\text { in pasture and partly wooded }\end{array}$ & none & $\begin{array}{l}\text { no survey needed } \\
\text { unless impacts extend } \\
\text { beyond existing } \\
\text { disturbed areas }\end{array}$ \\
\hline & Fannin & $\begin{array}{l}\text { Impact Evaluation; } \\
\text { bridge replacement on } \\
\text { CR } 656 \text { (specific plans } \\
\text { not available) }\end{array}$ & $\begin{array}{l}\text { Holocene alluvium }(2+\mathrm{m}) \text { along Rock } \\
\text { Creek and Cretaceous Bonham Marl } \\
\text { uplands; Elbon silty clay loam, Lassiter } \\
\text { silt loam, and Wilson-Normangee- } \\
\text { Crockett soils }\end{array}$ & $\begin{array}{l}\text { rural; adjacent lands are partly } \\
\text { in pasture and partly wooded }\end{array}$ & none & $\begin{array}{l}\text { no survey needed } \\
\text { unless impacts extend } \\
\text { beyond existing } \\
\text { disturbed areas }\end{array}$ \\
\hline & Red River & $\begin{array}{l}\text { I mpact Evaluation; } \\
\text { bridge replacement on } \\
\text { FM } 909 \text { (specific plans } \\
\text { not available) }\end{array}$ & $\begin{array}{l}\text { Holocene alluvium (5-6 m) along } \\
\text { Cuthand Creek; Kaufman-Gladewater } \\
\text { soils; adjacent uplands are Cretaceous } \\
\text { Marlbrook Marl and Navarro Group }\end{array}$ & $\begin{array}{l}\text { rural; adjacent lands are partly } \\
\text { in pasture and partly wooded }\end{array}$ & none & $\begin{array}{l}\text { no survey needed } \\
\text { unless impacts extend } \\
\text { beyond existing } \\
\text { disturbed areas }\end{array}$ \\
\hline & Red River & $\begin{array}{l}\text { I mpact Evaluation; } \\
\text { bridge replacement on } \\
\text { FM } 909 \text { (specific plans } \\
\text { not available) }\end{array}$ & $\begin{array}{l}\text { Holocene alluvium (1.0-1.5 m) along } \\
\text { Frances Creek and Cretaceous Marlbrook } \\
\text { Marl and Navarro Group uplands; Naha- } \\
\text { tche silty clay loam, Woodtell fine sandy } \\
\text { loam, and Kullit-Addielou complex soils }\end{array}$ & $\begin{array}{l}\text { rural; adjacent lands are partly } \\
\text { in pasture and partly wooded }\end{array}$ & none & $\begin{array}{l}\text { no survey needed } \\
\text { unless impacts extend } \\
\text { beyond existing } \\
\text { disturbed areas }\end{array}$ \\
\hline & Red River & $\begin{array}{l}\text { I mpact Evaluation; } \\
\text { bridge replacement on } \\
\text { FM } 410 \text { (specific plans } \\
\text { not available) }\end{array}$ & $\begin{array}{l}\text { Holocene alluvium ( } 3 \mathrm{~m} \text { ) along Scatter } \\
\text { Creek and Cretaceous Blossom Sand } \\
\text { and Brownstone Marl uplands; Woodtell } \\
\text { fine sandy loam soils }\end{array}$ & $\begin{array}{l}\text { urban; adjacent lands are } \\
\text { residential areas with } \\
\text { maintained yards }\end{array}$ & none & $\begin{array}{l}\text { no survey needed } \\
\text { unless impacts extend } \\
\text { beyond existing } \\
\text { disturbed areas }\end{array}$ \\
\hline
\end{tabular}


Table 1, continued

\begin{tabular}{|c|c|c|c|c|c|c|}
\hline $\begin{array}{l}\text { Work } \\
\text { Order }\end{array}$ & County & Project Type & Topographic/Geologic Setting & Land Use/Negetation & Sites & Recommendations \\
\hline & Red River & $\begin{array}{l}\text { Impact Evaluation; } \\
\text { bridge replacement on } \\
\text { FM } 410 \text { (specific plans } \\
\text { not available) }\end{array}$ & $\begin{array}{l}\text { Holocene alluvium }(2+\mathrm{m}) \text { along Wildcat } \\
\text { Creek and Cretaceous Blossom Sand } \\
\text { and Brownstone Marl uplands; } \\
\text { Nahatche silty clay loam and Woodtell } \\
\text { fine sandy loam soils }\end{array}$ & $\begin{array}{l}\text { rural; adjacent lands are partly } \\
\text { in pasture and partly wooded }\end{array}$ & none & $\begin{array}{l}\text { no survey needed } \\
\text { unless impacts extend } \\
\text { beyond existing } \\
\text { disturbed areas }\end{array}$ \\
\hline & Red River & $\begin{array}{l}\text { Impact Evaluation; } \\
\text { bridge replacement on } \\
\text { FM } 910 \text { (specific plans } \\
\text { not available) }\end{array}$ & $\begin{array}{l}\text { Holocene alluvium ( } 4-5 \mathrm{~m} \text { ) along } \\
\text { Cuthand Creek; Gladewater clay soils; } \\
\text { adjacent uplands are Cretaceous } \\
\text { Marlbrook Marl and Navarro Group }\end{array}$ & $\begin{array}{l}\text { rural; adjacent lands are partly } \\
\text { in pasture and partly wooded }\end{array}$ & none & $\begin{array}{l}\text { no survey needed } \\
\text { unless impacts extend } \\
\text { beyond existing } \\
\text { disturbed areas }\end{array}$ \\
\hline 28 & Erath & $\begin{array}{l}\text { Survey ( } 2 \text { trenches); } \\
\text { bridge replacement on } \\
\text { CR } 230 \text { ( } 0.5 \text { acres of new } \\
\text { ROW and construction } \\
\text { easements) }\end{array}$ & $\begin{array}{l}\text { Holocene alluvium (1.5-2.0 m) along a } \\
\text { tributary of Duffau Creek and } \\
\text { Cretaceous Paluxy and Walnut } \\
\text { Formation uplands; Frio clay loam, } \\
\text { Purves-Dugout complex, and Duffau fine } \\
\text { sandy loam soils }\end{array}$ & $\begin{array}{l}\text { rural; adjacent lands are partly } \\
\text { in pasture and partly wooded }\end{array}$ & none & no further work \\
\hline \multirow[t]{4}{*}{29} & Collin & $\begin{array}{l}\text { Impact Evaluation; } 3 \\
\text { bridge replacements on } \\
\text { FM } 545 \text { ( } 3.1 \text { acres of new } \\
\text { ROW) }\end{array}$ & $\begin{array}{l}\text { Holocene alluvium }(2.5+\mathrm{m}) \text { al ong Pilot } \\
\text { Grove Creek and Cretaceous Ozan } \\
\text { Formation uplands; Trinity clay, } \\
\text { Houston Black clay, Lewisville silty } \\
\text { clay, and Altoga silty clay soils }\end{array}$ & $\begin{array}{l}\text { rural; adjacent lands are partly } \\
\text { in pasture and partly wooded }\end{array}$ & none & survey new ROW \\
\hline & Denton & $\begin{array}{l}\text { Impact Evaluation; bridge } \\
\text { replacement and road } \\
\text { realignment on FM } 1173 \\
\text { ( } 2 \text { acres of new ROW) }\end{array}$ & $\begin{array}{l}\text { Holocene alluvium }(<1 \mathrm{~m}) \text { along North } \\
\text { Hickory Creek and Cretaceous Fort } \\
\text { Worth Limestone-Duck Creek Formation } \\
\text { uplands; Frio silty clay loam, Branyon } \\
\text { day, Somervell gravelly loam, and } \\
\text { Sanger clay soils }\end{array}$ & $\begin{array}{l}\text { rural; adjacent lands are partly } \\
\text { in pasture and partly wooded }\end{array}$ & none & no survey needed \\
\hline & Denton & $\begin{array}{l}\text { Impact Evaluation; } 2 \\
\text { bridge replacements and } \\
\text { widening of } 17.5 \mathrm{~km} \text { of } \\
\text { FM } 1171 \text { ( } 85 \text { acres of } \\
\text { new ROW and } \\
\text { easements) }\end{array}$ & $\begin{array}{l}\text { Cretaceous Woodbine Formation, Pawpaw } \\
\text { Formation-Weno Limestone-Denton Clay, } \\
\text { and Grayson Marl uplands; Pleistocene } \\
\text { terrace deposits; and Holocene alluvium } \\
(2-4 \text { m) along Graham Branch and } \\
\text { Whites Branch; Birome-Gasil-Callisburg, } \\
\text { association, Slidell-Sanger association, } \\
\text { and Frio silty clay soils }\end{array}$ & $\begin{array}{l}\text { rural to urban; adjacent lands } \\
\text { are fields, pastures, wooded, } \\
\text { residential areas, and } \\
\text { commercial developments }\end{array}$ & none & $\begin{array}{l}\text { survey in existing ROW } \\
\text { at Graham Branch; } \\
\text { survey new ROW at } \\
\text { Whites Branch; survey } \\
\text { new ROW at Sharps } \\
\text { Branch and possible } \\
\text { historic housesite } \\
\text { nearby }\end{array}$ \\
\hline & Denton & $\begin{array}{l}\text { Impact Evaluation; } \\
\text { bridge replacement on }\end{array}$ & $\begin{array}{l}\text { Holocene alluvium ( } 1 \mathrm{~m} \text { ) along Loving } \\
\text { Branch and Cretaceous Woodbine }\end{array}$ & $\begin{array}{l}\text { semirural; adjacent lands are } \\
\text { partly in pasture and partly in }\end{array}$ & none & no survey needed \\
\hline
\end{tabular}


Table 1, continued

\begin{tabular}{|c|c|c|c|c|c|c|}
\hline $\begin{array}{l}\text { Work } \\
\text { Order }\end{array}$ & County & Project Type & Topographic/Geologic Setting & Land Use/Vegetation & Sites & Recommendations \\
\hline & $\begin{array}{l}\text { Denton, } \\
\text { continued }\end{array}$ & FM 1830 (no new ROW) & $\begin{array}{l}\text { Formation uplands; Silstid loamy fine } \\
\text { sand, Bunyan fine sandy loam, and } \\
\text { Birome-Rayex-Aubrey soils }\end{array}$ & maintained lawns & & \\
\hline 30 & - & Produce synthetic report & - & - & - & - \\
\hline \multirow[t]{2}{*}{31} & Hill & $\begin{array}{l}\text { Survey ( } 4 \text { trenches, } 3 \\
\text { shovel tests); bridge } \\
\text { replacement on FM } 744 \\
\text { ( } 0.4 \text { acres of new ROW) }\end{array}$ & $\begin{array}{l}\text { Holocene alluvium (1-2 m) along Four } \\
\text { Mile Creek; Tinn clay soils; adjacent } \\
\text { uplands are Cretaceous Ozan Formation }\end{array}$ & $\begin{array}{l}\text { rural; adjacent lands are partly } \\
\text { in fields, partly in pastures, and } \\
\text { partly wooded }\end{array}$ & none & no further work \\
\hline & Bell & $\begin{array}{l}\text { I mpact Evaluation; } \\
\text { widening of } 8 \mathrm{~km} \text { of SH } \\
36 \text {, including construc- } \\
\text { tion of new } 3.8-\mathrm{km} \\
\text { bypass (with } 3 \text { bridges) } \\
\text { ( } 85 \text { acres of new ROW) }\end{array}$ & $\begin{array}{l}\text { Cretaceous Ozan Formation uplands } \\
\text { with Holocene alluvium ( }<1-2 \mathrm{~m} \text { ) along } \\
\text { Knob Creek, Margie Lou Branch, and } 5 \\
\text { tributaries to these creeks }\end{array}$ & $\begin{array}{l}\text { rural; adjacent lands are mostly } \\
\text { in pastures and fields }\end{array}$ & none & $\begin{array}{l}\text { survey new ROW at } \\
\text { Knob Creek and new } \\
\text { bypass at Margie Lou } \\
\text { Branch and } 2 \\
\text { tributaries }\end{array}$ \\
\hline \multirow[t]{3}{*}{32} & Cass & $\begin{array}{l}\text { Survey ( } 7 \text { trenches and } 4 \\
\text { shovel tests); bridge } \\
\text { replacement and road } \\
\text { realignment on FM } 250 \\
\text { ( } 3.9 \text { acres of new ROW) }\end{array}$ & $\begin{array}{l}\text { Holocene alluvium along Black Cypress } \\
\text { Creek and E ocene Queen City } \\
\text { Formation uplands; Darco-Fuquay } \\
\text { association soils }\end{array}$ & $\begin{array}{l}\text { rural; adjacent lands are mostly } \\
\text { wooded }\end{array}$ & $41 C S 143$ & no further work \\
\hline & Cass & $\begin{array}{l}\text { Survey ( } 7 \text { shovel tests); } \\
\text { bridge replacement on } \\
\text { FM } 250 \text { ( } 1 \text { acre of new } \\
\text { ROW and construction } \\
\text { easement) }\end{array}$ & $\begin{array}{l}\text { Holocene alluvium along Arbery Branch } \\
\text { and E ocene Queen City Formation } \\
\text { uplands; Darco-F uquay association soils }\end{array}$ & $\begin{array}{l}\text { rural; adjacent lands are mostly } \\
\text { wooded }\end{array}$ & none & no further work \\
\hline & Cass & $\begin{array}{l}\text { Survey (11 trenches, } 4 \\
\text { shovel tests ); bridge } \\
\text { replacement and road } \\
\text { realignment on FM } 250 \\
\text { ( } 4.5 \text { acres of new ROW) }\end{array}$ & $\begin{array}{l}\text { Holocene alluvium along Kelly Creek } \\
\text { and E ocene Queen City Formation } \\
\text { uplands; Darco-F uquay association soils }\end{array}$ & $\begin{array}{l}\text { rural; adjacent lands are mostly } \\
\text { wooded }\end{array}$ & $41 C S 144$ & no further work \\
\hline \multirow[t]{2}{*}{33} & $\begin{array}{l}\text { Gregg and } \\
\text { Upshur }\end{array}$ & $\begin{array}{l}\text { Impact Evaluation; } \\
\text { widening of } 1.8 \mathrm{~km} \text { of } \\
\text { U.S. Hwy } 80 \text { ( } 6 \text { acres of } \\
\text { new ROW) }\end{array}$ & $\begin{array}{l}\text { Eocene Weches Formation uplands; } \\
\text { Bowie fine sandy loam, Bowie urban } \\
\text { land complex, and Cuthbert fine sandy } \\
\text { loam soils }\end{array}$ & $\begin{array}{l}\text { urban; adjacent lands are mostly } \\
\text { residential areas and commercial } \\
\text { developments }\end{array}$ & none & $\begin{array}{l}\text { no survey except for } \\
\text { possible historic } \\
\text { housesite in new ROW }\end{array}$ \\
\hline & $\begin{array}{l}\text { Gregg and } \\
\text { Upshur }\end{array}$ & $\begin{array}{l}\text { Survey ( } 3 \text { trenches, } 2 \\
\text { shovel tests); bridge }\end{array}$ & $\begin{array}{l}\text { Holocene alluvium }(2.1+m) \text { al ong Glade } \\
\text { Creek and Eocene Weches F ormation }\end{array}$ & $\begin{array}{l}\text { semiurban; adjacent lands are } \\
\text { mostly in pasture with oil/gas }\end{array}$ & none & no further work \\
\hline
\end{tabular}


Table 1, continued

\begin{tabular}{|c|c|c|c|c|c|c|}
\hline $\begin{array}{l}\text { Work } \\
\text { Order }\end{array}$ & County & Project Type & Topographic/Geologic Setting & Land Use/Vegetation & Sites & Recommendations \\
\hline & $\begin{array}{l}\text { Gregg and } \\
\text { Upshur, } \\
\text { continued }\end{array}$ & $\begin{array}{l}\text { replacement and road } \\
\text { widening on U.S. Hwy } \\
80 \text { ( } 3 \text { acres of new ROW) }\end{array}$ & $\begin{array}{l}\text { uplands; I uka fine sandy loam, Bowie } \\
\text { fine sandy loam, and Tenaha loamy fine } \\
\text { sand soils }\end{array}$ & wells & & \\
\hline 34 & Collin & $\begin{array}{l}\text { Survey ( } 3 \text { trenches); } 3 \\
\text { bridge replacements on } \\
\text { FM } 545 \text { ( } 3.1 \text { acres of new } \\
\text { ROW) }\end{array}$ & $\begin{array}{l}\text { Holocene alluvium }(2.5+\mathrm{m}) \text { along Pilot } \\
\text { Grove Creek; Trinity clay soils; adjacent } \\
\text { uplands are Cretaceous Ozan Formation }\end{array}$ & $\begin{array}{l}\text { rural; adjacent lands are partly } \\
\text { in pasture and partly wooded }\end{array}$ & $\begin{array}{l}\text { possible pre- } \\
\text { historic site } \\
\text { represented } \\
\text { by bovid (?) } \\
\text { bones and } \\
\text { charcoal }\end{array}$ & $\begin{array}{l}\text { date charcoal and } \\
\text { analyze bones to } \\
\text { determine if prehis- } \\
\text { toric; if so, additional } \\
\text { survey/testing needed }\end{array}$ \\
\hline \multirow[t]{2}{*}{35} & Falls & $\begin{array}{l}\text { Impact Evaluation; } \\
\text { widening of } 5.9 \mathrm{~km} \text { of } \\
\text { SH } 6 \text { (no new ROW) }\end{array}$ & $\begin{array}{l}\text { Pleistocene terrace deposits flanking Big } \\
\text { Creek on the east side of the Brazos } \\
\text { River valley; Wilson silty clay loam and } \\
\text { Crockett fine sandy loam soils }\end{array}$ & $\begin{array}{l}\text { rural; adjacent lands are mostly } \\
\text { in pasture }\end{array}$ & 41FA65 & no survey needed \\
\hline & Falls & $\begin{array}{l}\text { Survey with Geoarcheo- } \\
\text { logical Assessment ( } 11 \\
\text { trenches); } 2 \text { bridge } \\
\text { replacements and road } \\
\text { widening on SH } 6 \text { (no } \\
\text { new ROW) }\end{array}$ & $\begin{array}{l}\text { Holocene alluvium }(1.5+\mathrm{m}) \text { along Big } \\
\text { Creek; Ships clay soils; adjacent uplands } \\
\text { are Pleistocene terrace deposits }\end{array}$ & $\begin{array}{l}\text { rural; adjacent lands are mostly } \\
\text { in pasture }\end{array}$ & none & no further work \\
\hline 36 & Coryell & $\begin{array}{l}\text { I mpact Evaluation; } \\
\text { widening of } 3.6 \mathrm{~km} \text { of } \\
\text { FM } 107 \text { (no new ROW) }\end{array}$ & $\begin{array}{l}\text { Cretaceous Weno Limestone, Main } \\
\text { Street Limestone, and Grayson Marl } \\
\text { uplands; Denton silty clay, Slidell silty } \\
\text { clay, Bolar gravelly clay loam, and } \\
\text { Purves gravelly silty clay soils }\end{array}$ & $\begin{array}{l}\text { semirural; adjacent lands are } \\
\text { partly in pasture, partly in fields, } \\
\text { and partly in residential areas }\end{array}$ & none & no survey needed \\
\hline \multirow[t]{3}{*}{37} & Hunt & $\begin{array}{l}\text { Impact Evaluation; } \\
\text { bridge replacement on } \\
\text { FM } 499 \text { (specific plans } \\
\text { not available) }\end{array}$ & $\begin{array}{l}\text { Holocene alluvium }(4-6+m) \text { along Lynn } \\
\text { Creek; Hopco silt loam soils; adjacent } \\
\text { uplands are Paleocene Kincaid } \\
\text { Formation }\end{array}$ & rural; adjacent lands are wooded & none & $\begin{array}{l}\text { no survey needed } \\
\text { unless impacts extend } \\
\text { beyond existing } \\
\text { disturbed areas }\end{array}$ \\
\hline & Hunt & $\begin{array}{l}\text { Impact Evaluation; } 2 \\
\text { bridge replacements on } \\
\text { SH } 224 \text { (no new ROW) }\end{array}$ & $\begin{array}{l}\text { Holocene alluvium }(6-8+m) \text { along the } \\
\text { Sabine River; Kaufman day soils; ad- } \\
\text { jacent uplands are Cretaceous Neyland- } \\
\text { ville and Marlbrook Marl Formations }\end{array}$ & $\begin{array}{l}\text { semiurban; adjacent lands are } \\
\text { mostly wooded with commercial } \\
\text { developments on adjacent } \\
\text { uplands }\end{array}$ & none & $\begin{array}{l}\text { survey existing ROW } \\
\text { south of road except } \\
\text { northeast of relief } \\
\text { structure }\end{array}$ \\
\hline & Hunt & $\begin{array}{l}\text { Impact Evaluation; } \\
\text { bridge replacement on } \\
\text { SH } 34 \text { (no new ROW) }\end{array}$ & $\begin{array}{l}\text { Holocene alluvium }(2-3+\mathrm{m}) \text { along South } \\
\text { Sulphur River; Tinn clay and Hopco silt } \\
\text { loam soils; adjacent uplands are }\end{array}$ & $\begin{array}{l}\text { rural; adjacent lands are mostly } \\
\text { wooded }\end{array}$ & none & $\begin{array}{l}\text { survey existing ROW } \\
\text { south of bridge if } \\
\text { impacts extend below }\end{array}$ \\
\hline
\end{tabular}


Table 1, continued

\begin{tabular}{|c|c|c|c|c|c|c|}
\hline $\begin{array}{l}\text { Work } \\
\text { Order }\end{array}$ & County & Project Type & Topographic/Geologic Setting & Land Use/Vegetation & Sites & Recommendations \\
\hline & $\begin{array}{l}\text { Hunt, } \\
\text { continued }\end{array}$ & & $\begin{array}{l}\text { Cretaceous Wolfe City Formation, Pecan } \\
\text { Gap Chalk, and Pleistocene terrace } \\
\text { deposits }\end{array}$ & & & $\begin{array}{l}\text { existing disturbed } \\
\text { areas }\end{array}$ \\
\hline & Hunt & $\begin{array}{l}\text { Impact Evaluation; } \\
\text { bridge replacement on } \\
\text { CR } 522 \text { (no new ROW) }\end{array}$ & $\begin{array}{l}\text { Holocene alluvium }(4-6+m) \text { along } \\
\text { Sabine River; Kaufman clay soils; } \\
\text { adjacent uplands are Pleistocene terrace } \\
\text { deposits and Paleocene Navarro Group }\end{array}$ & $\begin{array}{l}\text { rural; adjacent lands are partly } \\
\text { wooded and partly in pasture }\end{array}$ & none & no survey needed \\
\hline & Hunt & $\begin{array}{l}\text { Impact Evaluation; } \\
\text { bridge replacement on } \\
\text { CR } 523 \text { (no new ROW) }\end{array}$ & $\begin{array}{l}\text { Holocene alluvium }(2.5+\mathrm{m}) \text { al ong Lake } \\
\text { Fork Creek; Hopco silt loam and Wilson } \\
\text { silt loam soils; adjacent uplands are } \\
\text { Pal eocene Kincaid Formation }\end{array}$ & $\begin{array}{l}\text { rural; adjacent lands are partly } \\
\text { wooded and partly in pasture }\end{array}$ & none & no survey needed \\
\hline & Hunt & $\begin{array}{l}\text { Impact Evaluation; } \\
\text { bridge replacement on } \\
\text { FM } 816 \text { (no new ROW) }\end{array}$ & $\begin{array}{l}\text { Holocene alluvium (3-4+m) along } \\
\text { Spring Creek; Tinn clay soils; adjacent } \\
\text { uplands are Cretaceous Ozan Formation }\end{array}$ & $\begin{array}{l}\text { rural; adjacent lands are mostly } \\
\text { in pasture }\end{array}$ & none & no survey needed \\
\hline & Lamar & $\begin{array}{l}\text { I mpact Evaluation; } \\
\text { bridge replacement on } \\
\text { FM } 2122 \text { (no new ROW) }\end{array}$ & $\begin{array}{l}\text { Holocene alluvium (1.5-3.0 m) along } \\
\text { Maxwell Creek; Elbon silty clay loam } \\
\text { soils; adjacent uplands are Cretaceous } \\
\text { Gober Chalk and Ozan Formations }\end{array}$ & $\begin{array}{l}\text { rural; adjacent lands are mostly } \\
\text { in pasture }\end{array}$ & none & no survey needed \\
\hline 38 & Wise & $\begin{array}{l}\text { I mpact Evaluation; } \\
\text { widening of } 17.2 \mathrm{~km} \text { of } \\
\text { U.S. H wy } 380 \text { ( } 155 \text { acres } \\
\text { of new ROW) }\end{array}$ & $\begin{array}{l}\text { Cretaceous Goodland Limestone, } \\
\text { Walnut Clay, and Antlers Sand uplands } \\
\text { and Holocene alluvium ( } 2-5 \text { m) along } \\
\text { Catlett and Denton Creeks; Brackett- } \\
\text { Aledo complex, Batsil fine sandy loam, } \\
\text { Ponder clay loam, Purves clay, Sanger } \\
\text { clay, Somervell-Aledo complex, Frio silty } \\
\text { clay loam, and Trinity clay soils }\end{array}$ & $\begin{array}{l}\text { rural; adjacent lands are mostly } \\
\text { in pasture }\end{array}$ & none & $\begin{array}{l}\text { survey new ROW at } \\
\text { Catlett Creek, Denton } \\
\text { Creek, Sweetwater } \\
\text { Creek tributary, and } \\
\text { pimple mound field } \\
\text { west of CR } 2311\end{array}$ \\
\hline \multirow[t]{2}{*}{39} & Bell & $\begin{array}{l}\text { Impact Evaluation; } \\
\text { bridge replacement on } \\
\text { SH } 36 \text { (specific plans not } \\
\text { available) }\end{array}$ & $\begin{array}{l}\text { Cretaceous Edwards and Comanche } \\
\text { Peak Limestone uplands adjacent to } \\
\text { Belton Lake; Real, Purves, Tarrant, } \\
\text { Crawford clay, and Speck soils }\end{array}$ & $\begin{array}{l}\text { semirural; adjacent lands are } \\
\text { wooded, semiopen private lands, } \\
\text { and parks }\end{array}$ & 41BL 1103 & $\begin{array}{l}\text { no survey needed } \\
\text { unless impacts extend } \\
\text { beyond existing } \\
\text { disturbed areas }\end{array}$ \\
\hline & Bell & $\begin{array}{l}\text { Impact Evaluation; } \\
\text { bridge replacement on } \\
\text { SH } 95 \text { (specific plans not } \\
\text { available) }\end{array}$ & $\begin{array}{l}\text { Holocene alluvium }(2+m) \text { along the } \\
\text { Little River; Bosque clay loam, Frio silty } \\
\text { clay, and Trinity clay soils; adjacent } \\
\text { uplands are Pleistocene terrace deposits }\end{array}$ & $\begin{array}{l}\text { rural; adjacent lands are in } \\
\text { pasture, pecan orchards, and } \\
\text { drag strip }\end{array}$ & none & $\begin{array}{l}\text { no survey needed } \\
\text { unless impacts extend } \\
\text { beyond existing } \\
\text { disturbed areas }\end{array}$ \\
\hline
\end{tabular}


Table 1, continued

\begin{tabular}{|c|c|c|c|c|c|c|}
\hline $\begin{array}{l}\text { Work } \\
\text { Order }\end{array}$ & County & Project Type & Topographic/Geologic Setting & Land Use/Vegetation & Sites & Recommendations \\
\hline & Bell & $\begin{array}{l}\text { Impact Evaluation; } \\
\text { bridge replacement on } \\
\text { CR } 382 \text { (specific plans } \\
\text { not available) }\end{array}$ & $\begin{array}{l}\text { Holocene alluvium }(5+\mathrm{m}) \text { along the } \\
\text { Little River; Frio silty clay soils; } \\
\text { adjacent uplands are Pleistocene terrace } \\
\text { deposits }\end{array}$ & $\begin{array}{l}\text { rural; adjacent lands are mostly } \\
\text { in pasture with woods along the } \\
\text { river }\end{array}$ & none & $\begin{array}{l}\text { no survey needed } \\
\text { unless impacts extend } \\
\text { beyond existing } \\
\text { disturbed areas }\end{array}$ \\
\hline & Hamilton & $\begin{array}{l}\text { Impact Evaluation; } \\
\text { bridge replacement on } \\
\text { CR } 284 \text { (specific plans } \\
\text { not available) }\end{array}$ & $\begin{array}{l}\text { Holocene alluvium (1 m) along } \\
\text { Alexander Creek; Bosque clay loam and } \\
\text { Frio silty clay soils; adjacent uplands } \\
\text { are Cretaceous Glen Rose Formation }\end{array}$ & $\begin{array}{l}\text { rural; adjacent lands are partly } \\
\text { wooded and partly in pasture }\end{array}$ & none & $\begin{array}{l}\text { no survey needed } \\
\text { unless impacts extend } \\
\text { beyond existing } \\
\text { disturbed areas }\end{array}$ \\
\hline & Hamilton & $\begin{array}{l}\text { I mpact Evaluation; } \\
\text { bridge replacement on } \\
\text { CR } 296 \text { (specific plans } \\
\text { not available) }\end{array}$ & $\begin{array}{l}\text { Holocene alluvium ( } 2-3 \mathrm{~m} \text { ) along Bear } \\
\text { Creek; Bosque clay loam and Frio silty } \\
\text { clay soils; adjacent uplands are } \\
\text { Cretaceous Glen Rose Formation }\end{array}$ & $\begin{array}{l}\text { rural; adjacent lands are partly } \\
\text { wooded and partly in pasture }\end{array}$ & none & $\begin{array}{l}\text { no survey needed } \\
\text { unless impacts extend } \\
\text { beyond existing } \\
\text { disturbed areas }\end{array}$ \\
\hline & Hamilton & $\begin{array}{l}\text { Impact Evaluation; } \\
\text { bridge replacement on } \\
\text { CR } 294 \text { (1.7 acres of new } \\
\text { ROW) }\end{array}$ & $\begin{array}{l}\text { Holocene alluvium ( } 2 \mathrm{~m} \text { ) al ong Alex } \\
\text { Branch; Bosque clay loam and Frio silty } \\
\text { clay soils; adjacent uplands are } \\
\text { Cretaceous Glen Rose Formation }\end{array}$ & $\begin{array}{l}\text { rural; adjacent lands are partly } \\
\text { wooded and partly in pasture }\end{array}$ & none & $\begin{array}{l}\text { survey new ROW west } \\
\text { of the bridge }\end{array}$ \\
\hline & Hamilton & $\begin{array}{l}\text { I mpact Evaluation; } \\
\text { bridge replacement on } \\
\text { CR } 260 \text { (specific plans } \\
\text { not available) }\end{array}$ & $\begin{array}{l}\text { Holocene alluvium (2-3 m) along North } \\
\text { Bosque River tributary; Bosque clay loam } \\
\text { and Frio silty dlay soils; adjacent uplands } \\
\text { are Cretaceous Glen Rose Formation }\end{array}$ & $\begin{array}{l}\text { rural; adjacent lands are partly } \\
\text { wooded and partly in fields }\end{array}$ & none & $\begin{array}{l}\text { no survey needed } \\
\text { unless impacts extend } \\
\text { beyond existing } \\
\text { disturbed areas }\end{array}$ \\
\hline & Hill & $\begin{array}{l}\text { I mpact Evaluation; } \\
\text { bridge replacement on } \\
\text { CR } 469 \text { (specific plans } \\
\text { not available) }\end{array}$ & $\begin{array}{l}\text { Holocene all luvium }(3 \mathrm{~m} \text { ) along } \\
\text { Cottonwood Creek; Tinn clay soils; } \\
\text { adjacent uplands are Cretaceous } \\
\text { Woodbine and Eagle Ford Formations }\end{array}$ & $\begin{array}{l}\text { rural; adjacent lands are partly } \\
\text { wooded and partly in pasture }\end{array}$ & none & $\begin{array}{l}\text { no survey needed } \\
\text { unless impacts extend } \\
\text { beyond existing } \\
\text { disturbed areas }\end{array}$ \\
\hline & Hill & $\begin{array}{l}\text { Impact Evaluation; } \\
\text { bridge replacement on } \\
\text { CR } 114 \text { (specific plans } \\
\text { not available) }\end{array}$ & $\begin{array}{l}\text { Holocene alluvium }(4-5+m) \text { along } \\
\text { J ackson Creek; Houston Black clay and } \\
\text { Wilson clay loam soils; adjacent uplands } \\
\text { are Cretaceous Wolfe City and Pecan } \\
\text { Gap Chalk Formations }\end{array}$ & $\begin{array}{l}\text { rural; adjacent lands are partly } \\
\text { wooded and partly in pasture }\end{array}$ & none & $\begin{array}{l}\text { no survey needed } \\
\text { unless impacts extend } \\
\text { beyond existing } \\
\text { disturbed areas }\end{array}$ \\
\hline & McLennan & $\begin{array}{l}\text { Impact Evaluation; } \\
\text { bridge replacement on } \\
\text { CR } 346 \text { (specific plans } \\
\text { not available) }\end{array}$ & $\begin{array}{l}\text { Holocene alluvium ( } 1 \mathrm{~m} \text { ) along Live Oak } \\
\text { Creek; Trinity clay and Houston Black } \\
\text { clay soils; adjacent uplands are } \\
\text { Cretaceous Grayson Marl and Main } \\
\text { Street Limestone Formations }\end{array}$ & $\begin{array}{l}\text { rural; adjacent lands are partly } \\
\text { wooded and partly in pasture }\end{array}$ & none & $\begin{array}{l}\text { no survey needed } \\
\text { unless impacts extend } \\
\text { beyond existing } \\
\text { disturbed areas }\end{array}$ \\
\hline & McLennan & $\begin{array}{l}\text { Impact Evaluation; } \\
\text { bridge replacement on }\end{array}$ & $\begin{array}{l}\text { Holocene alluvium ( } 1 \mathrm{~m} \text { ) along Patten } \\
\text { Branch; Houston Black clay and }\end{array}$ & $\begin{array}{l}\text { rural; adjacent lands are mostly } \\
\text { in pasture }\end{array}$ & none & no survey needed \\
\hline
\end{tabular}


Table 1, continued

\begin{tabular}{|c|c|c|c|c|c|c|}
\hline $\begin{array}{l}\text { Work } \\
\text { Order }\end{array}$ & County & Project Type & Topographic/Geologic Setting & Land Use/Vegetation & Sites & Recommendations \\
\hline & $\begin{array}{l}\text { McLennan, } \\
\text { continued }\end{array}$ & $\begin{array}{l}\text { CR } 440 \text { (specific plans } \\
\text { not available) }\end{array}$ & $\begin{array}{l}\text { Houston Black gravelly clay soils; } \\
\text { adjacent uplands are Cretaceous South } \\
\text { Bosque and Lake Waco Formations }\end{array}$ & & & \\
\hline & McLennan & $\begin{array}{l}\text { Impact Evaluation; } \\
\text { bridge replacement on } \\
\text { CR } 774 \text { (specific plans } \\
\text { not available) }\end{array}$ & $\begin{array}{l}\text { Holocene alluvium }(5+\mathrm{m}) \text { along } \\
\text { Castleman Creek; Asa silty clay loam, } \\
\text { Asa very fine sandy loam, and Norwood } \\
\text { silty loam soils; adjacent uplands are } \\
\text { Cretaceous Ozan Formation and } \\
\text { Pleistocene terrace deposits }\end{array}$ & $\begin{array}{l}\text { rural; adjacent lands are } \\
\text { cultivated fields }\end{array}$ & none & $\begin{array}{l}\text { no survey needed } \\
\text { unless impacts extend } \\
\text { beyond existing } \\
\text { disturbed areas }\end{array}$ \\
\hline & McLennan & $\begin{array}{l}\text { Impact Evaluation; } \\
\text { bridge replacement on } \\
\text { CR } 581 \text { (specific plans } \\
\text { not available) }\end{array}$ & $\begin{array}{l}\text { Holocene alluvium ( } 3+\mathrm{m} \text { ) along } \\
\text { Tehuacana Creek; Trinity clay loam } \\
\text { soils; adjacent uplands are Cretaceous } \\
\text { Ozan Formation }\end{array}$ & $\begin{array}{l}\text { rural; adjacent lands are partly } \\
\text { wooded and partly in pasture }\end{array}$ & none & $\begin{array}{l}\text { no survey needed } \\
\text { unless impacts extend } \\
\text { beyond existing } \\
\text { disturbed areas }\end{array}$ \\
\hline \multirow[t]{2}{*}{40} & Panola & $\begin{array}{l}\text { Survey ( } 48 \text { shovel tests); } \\
3 \text { bridge and } 1 \text { culvert } \\
\text { replacements and road } \\
\text { realignment on FM } 10 \\
\text { (12 acres of new ROW) }\end{array}$ & $\begin{array}{l}\text { Holocene alluvium ( } 1.5+\mathrm{m} \text { ) along Murvaul } \\
\text { Creek and adjacent Eocene Wilcox Group } \\
\text { uplands; Nahatche day loam, Thenas fine } \\
\text { sandy loam to day loam, Sacul fine sandy } \\
\text { loam, and Bowie fine sandy loam soils }\end{array}$ & $\begin{array}{l}\text { rural; adjacent lands are mostly } \\
\text { wooded with some pastures }\end{array}$ & $\begin{array}{l}\text { 41PN175 } \\
\text { 41PN176 }\end{array}$ & $\begin{array}{l}\text { testing at } 41 P N 175 ; \\
\text { no further work at } \\
\text { 41PN176 }\end{array}$ \\
\hline & Titus & $\begin{array}{l}\text { Survey ( } 23 \text { shovel tests); } \\
\text { bridge replacement on } \\
\text { FM } 127 \text { ( } 2.3 \text { acres of new } \\
\text { ROW, } 0.4 \text { acres of } \\
\text { construction easements) }\end{array}$ & $\begin{array}{l}\text { Holocene alluvium }(2+\mathrm{m}) \text { along } \\
\text { Tankersley Creek and adjacent E ocene } \\
\text { Wilcox Group uplands; Estes clay loam, } \\
\text { Nahatche silty clay loam, and Woodtell } \\
\text { fine sandy loam soils }\end{array}$ & $\begin{array}{l}\text { rural; adjacent lands are partly } \\
\text { wooded and partly in pasture }\end{array}$ & $\begin{array}{l}41 T T 823 \\
41 T T 824\end{array}$ & no further work \\
\hline \multirow[t]{3}{*}{41} & Dallas & $\begin{array}{l}\text { Impact Evaluation; } \\
\text { bridge replacement on } \\
\text { Rylie Crest Dr. (specific } \\
\text { plans not available) }\end{array}$ & $\begin{array}{l}\text { Holocene alluvium }(1.5+\mathrm{m}) \text { along } \\
\text { Hickory Creek; Gowen clay loam soils; } \\
\text { adjacent uplands are Cretaceous Ozan } \\
\text { Formation }\end{array}$ & $\begin{array}{l}\text { semiurban; adjacent lands are } \\
\text { partly residential }\end{array}$ & none & $\begin{array}{l}\text { no survey needed } \\
\text { unless impacts extend } \\
\text { beyond existing } \\
\text { disturbed areas }\end{array}$ \\
\hline & Denton & $\begin{array}{l}\text { Impact Evaluation; } \\
\text { bridge replacement on } \\
\text { Country Club Rd. } \\
\text { (specific plans not } \\
\text { available) }\end{array}$ & $\begin{array}{l}\text { Thin Holocene alluvium along } \\
\text { Graveyard Branch tributary and } \\
\text { Cretaceous Grayson Marl and Main } \\
\text { Street Limestone uplands; Lewisville, } \\
\text { Navo, Birome-Rayex-Aubrey soils }\end{array}$ & $\begin{array}{l}\text { semirural; adjacent lands are } \\
\text { partly undevel oped and partly } \\
\text { residential }\end{array}$ & none & no survey needed \\
\hline & Ellis & $\begin{array}{l}\text { Impact Evaluation; } \\
\text { bridge replacement on } \\
\text { Ebenezer Rd. (specific } \\
\text { plans not available) }\end{array}$ & $\begin{array}{l}\text { Holocene alluvium (5-6+ m) along Grove } \\
\text { Creek; Trinity clay soils; adjacent } \\
\text { uplands are Cretaceous Ozan Formation }\end{array}$ & $\begin{array}{l}\text { rural; adjacent lands are partly } \\
\text { wooded and partly in fields }\end{array}$ & none & survey \\
\hline
\end{tabular}


Table 1, continued

\begin{tabular}{|c|c|c|c|c|c|c|}
\hline $\begin{array}{l}\text { Work } \\
\text { Order } \\
\end{array}$ & County & Project Type & Topographic/Geologic Setting & Land Use/Vegetation & Sites & Recommendations \\
\hline & Ellis & $\begin{array}{l}\text { Impact Evaluation; } \\
\text { bridge replacement on } \\
\text { West Main St. (specific } \\
\text { plans not available) }\end{array}$ & $\begin{array}{l}\text { Holocene alluvium ( } 2-3 \mathrm{~m} \text { ) al ong Red } \\
\text { Oak Creek; Frio silty clay soils; adjacent } \\
\text { uplands are Cretaceous Austin Chalk }\end{array}$ & $\begin{array}{l}\text { semirural; adjacent lands are } \\
\text { partly undevel oped and partly } \\
\text { residential }\end{array}$ & none & $\begin{array}{l}\text { no survey needed } \\
\text { unless impacts extend } \\
\text { beyond existing } \\
\text { disturbed areas }\end{array}$ \\
\hline & Kaufman & $\begin{array}{l}\text { Impact Evaluation; } \\
\text { bridge replacement on } \\
\text { CR } 313 \text { (specific plans } \\
\text { not available) }\end{array}$ & $\begin{array}{l}\text { Holocene alluvium (1.0-1.5 m) along } \\
\text { Muddy Cedar Creek tributary; Kemp } \\
\text { Ioam soils; adjacent uplands are } \\
\text { Paleocene Kincaid Formation }\end{array}$ & $\begin{array}{l}\text { rural; adjacent lands are partly } \\
\text { wooded and partly in pasture }\end{array}$ & none & no survey needed \\
\hline
\end{tabular}


in size (total acreage $=161$ ), with substantial parts (usually one-third to two-thirds) being disturbed by existing roads and bridges. These 4 surveys involved the excavation of 46 trenches and 15 shovel tests. The other 20 surveys were in relatively undisturbed proposed new rights of way or construction easements, with these varying from 0.2 to 13 acres (median $=2.9$ acres; total $=73$ acres). Ninetyeight trenches and 114 shovel tests were excavated in surveying these areas. Trenches and shovel tests usually were placed judgmentally rather than at specific intervals based on the size and shape of each survey area, distributions of Iandforms, accessibility, and the locations of known sites.

The trenches were at least $5 \mathrm{~m}$ long and $0.75 \mathrm{~m}$ wide, and usually they were at least $1.5 \mathrm{~m}$ deep (i.e., the anticipated maximum depth of substantial disturbance). After excavation, their walls were cleaned and examined for cultural materials. Stratigraphic descriptions were prepared for selected trenches to characterize the sediments. Shovel tests averaged $30 \mathrm{~cm}$ in diameter and were dug to varying depths depending on depth to bedrock, clay content, and water content. The sediments removed from shovel tests were screened through 1/4-inch-mesh hardware cloth. A standardized Survey Summary Form was completed noting whether the survey included a geoarcheological evaluation, describing the areas subjected to surface survey and visibility, indicating the number/depth/placement of shovel tests and trenches, listing the cultural materials observed/sites recorded, providing assessments/recommendations, and noting the personnel and time needed for the survey. Other documentation consisted of color photographs, Temporary Site Forms (for eventual submittal to the Texas Archeological Research Laboratory in TexSite format), stratigraphic profile descriptions, and project plans showing the locations of all trenches, shovel tests, and sites. Surveys usually were done by two-person crews; on Surveys with Geoarcheological Evaluations, one member of the crew was a Geoarcheologist. The amount of time required to complete the surveys varied depending on their size, the number of trenches and shovel tests excavated, and what was found. The range was 4-57 person-hours, with the median being 11.5 person-hours (excludes time spent by TxDOT personnel, including backhoe/Gradall operators).

\section{Synopsis of Work Orders}

As listed in Table 1, 8 of the 39 work orders involving fieldwork were in the Atlanta District (Cass, Gregg, Harrison, Morris, Panola, Titus, and Upshur Counties), 6 were in the Dallas District (Collin, Dallas, Denton, Ellis, and Kaufman Counties), 4 were in the Fort Worth District (Erath, Tarrant, and Wise Counties), 9 were in the Paris District (Delta, Fannin, Grayson, Hunt, Lamar, and Red River Counties), 11 were in the Waco District (Bell, Coryell, Falls, Hamilton, Hill, and McLennan Counties), and 1 was in both the Atlanta and Paris Districts (Bowie, Franklin, Harrison, Hopkins, Morris, Panola, and Rains Counties). The projects in the Atlanta District consisted of 9 I mpact Evaluations and 13 Surveys for the replacement of 24 bridges/relief structures and 6 road-widening projects. In the Dallas District, the work orders were for 16 Impact Evaluations and 1 Survey on 21 bridge/relief structure replacements, 1 roadwidening project, and 1 project involving construction of an exit ramp. The Fort Worth District work orders consisted of $3 \mathrm{Impact}$ Evaluations and 2 Surveys entailing 3 bridge/ relief structure replacements and 1 roadwidening project. In the Paris District, 71 Impact Evaluations and 2 Surveys focused on the replacement of 80 bridges/relief structures. Finally, the projects in the Waco District involved 20 Impact Evaluations, 3 Surveys, and 3 Surveys with Geoarcheological Evaluations; these work orders were for 23 bridge replacements and 6 road-widening projects.

Not surprising given the focus on bridge replacements, many of the projects $(n=75)$ were restricted to Holocene alluvial settings (see Table 1). An additional 57 I mpact Evaluations and Surveys encompassed upland margins as well as Holocene alluvium, with the uplands mapped as a variety of Cretaceous (Fredericksburg, Washita, Eagle Ford, Austin, Taylor, and Navarro Groups) and PaleoceneEocene (Midway, Wilcox, and Claiborne Groups) formations, as well as Pleistocene 
terrace deposits. The 11 projects that crossed mostly upland areas were on these same Cretaceous, Paleocene-Eocene, and Pleistocene deposits. A variety of soils are mapped for the project areas, ranging generally from loamy to clayey, sometimes stony, often shallow soils in the western part of the study area; to dark, calcareous, clayey soils of the Blackland Prairie; to loamy to sandy soils with clayey substrates in the Oak Woodlands and Piney Woods on the east. Common mapped Holocene alluvial soils in the areas examined during these work orders include Bunyan fine sandy loam, Elbon silty clay loam, Frio silty clay, Gladewater clay, Heiden clay, Hopco silt loam, I uka fine sandy loam, Kaufman clay, Lassiter silt loam, Leson clay, Nahatche clay loam, Tinn clay, and Trinity clay (see Table 1). Upland and old terrace soils in these areas include Crockett fine sandy loam, Cuthbert fine sandy loam, Fairlie-Houston Black clay, Ferris clay, Freestone loam, Lewisville silty clay, Normangee clay loam, Purves silty clay, Sacul fine sandy loam, Wilson silt loam, and Woodtell sandy loam.

Most of the I mpact Evaluations and Surveys ( $n=122)$ were in rural areas where adjacent lands were undeveloped and in pastures or woods (see Table 1). Ten projects were in settings that can be classified as semirural (i.e., largely undeveloped but adjacent to modern cemeteries, golf courses, gravel quarries, residential yards, and parks). Eleven project areas were in urban or semiurban settings (i.e., the cities of Balch Springs, Dallas, Deport, Detroit, Gladewater, Greenville, Marshall, Roxton, Sherman, and Temple).

Fourteen of the I mpact Evaluations resulted in a recommendation that an archeological survey be completed prior to construction (see Table 1). This was the case most often when construction plans called for new right of way or an easement across areas with substantial (i.e., at least $1 \mathrm{~m}$ thick), undisturbed Holocene deposits that could host buried, prehistoric archeological remains in good context. In 69 additional Impact Evaluations for which specific construction plans were not available (and thus specific areas to be affected not known), survey was recommended if areas outside the existing right of way, or below the zone of disturbance within the existing right of way (typically below 1.0-1.5 m), will be disturbed substantially. The remaining 36 I mpact Evaluations resulted in a recommendation that no survey be required based on the extent of disturbance and the limited potential for sites with good integrity. In most cases, these Transportation Activities will require no new right of way or easements, with all construction-related disturbances restricted to the existing rights of way.

Three of the Surveys investigated sites that were recommended for testing to assess eligibility for listing in the National Register of Historic Places and designation as State Archeological Landmarks (see Table 1). On two other surveys, it was recommended that recovered charcoal be radiocarbon dated to aid in making the decision about whether testing is needed. The other 19 Surveys either did not find any archeological sites $(n=14)$ or investigated sites that could be assessed as ineligible for National Register listing and State Archeological Landmark designation using the survey data $(n=5)$.

\section{I mpacts and Site Potential}

A primary thrust of the Surveys and especially the Impact Evaluations performed under this contract was documentation of existing impacts that would affect the potential of each project area to contain archeological sites with sufficient integrity to be eligible for listing in the National Register of Historic Places or designation as a State Archeological Landmark. In general, four kinds of disturbances were observed consistently within existing rights of way: fill sections, ditches, gullies, and underground utilities (Figure 4).

Fill sections to elevate the approaches to bridges above the adjacent floodplains were present at almost all of the bridge replacement project areas (Table 2). These fill sections ranged from less than $0.5 \mathrm{~m}$ in thickness to as much as $7 \mathrm{~m}$, but most extended 1-2 $\mathrm{m}$ above the natural surface. Horizontally, they extended as little as $10 \mathrm{~m}$ from each end of a bridge to as much as several hundred meters, depending on the size of the valley and the kind of road. The higher and longer fill sections tended to be associated with the larger roads and larger streams. Typically, fill 


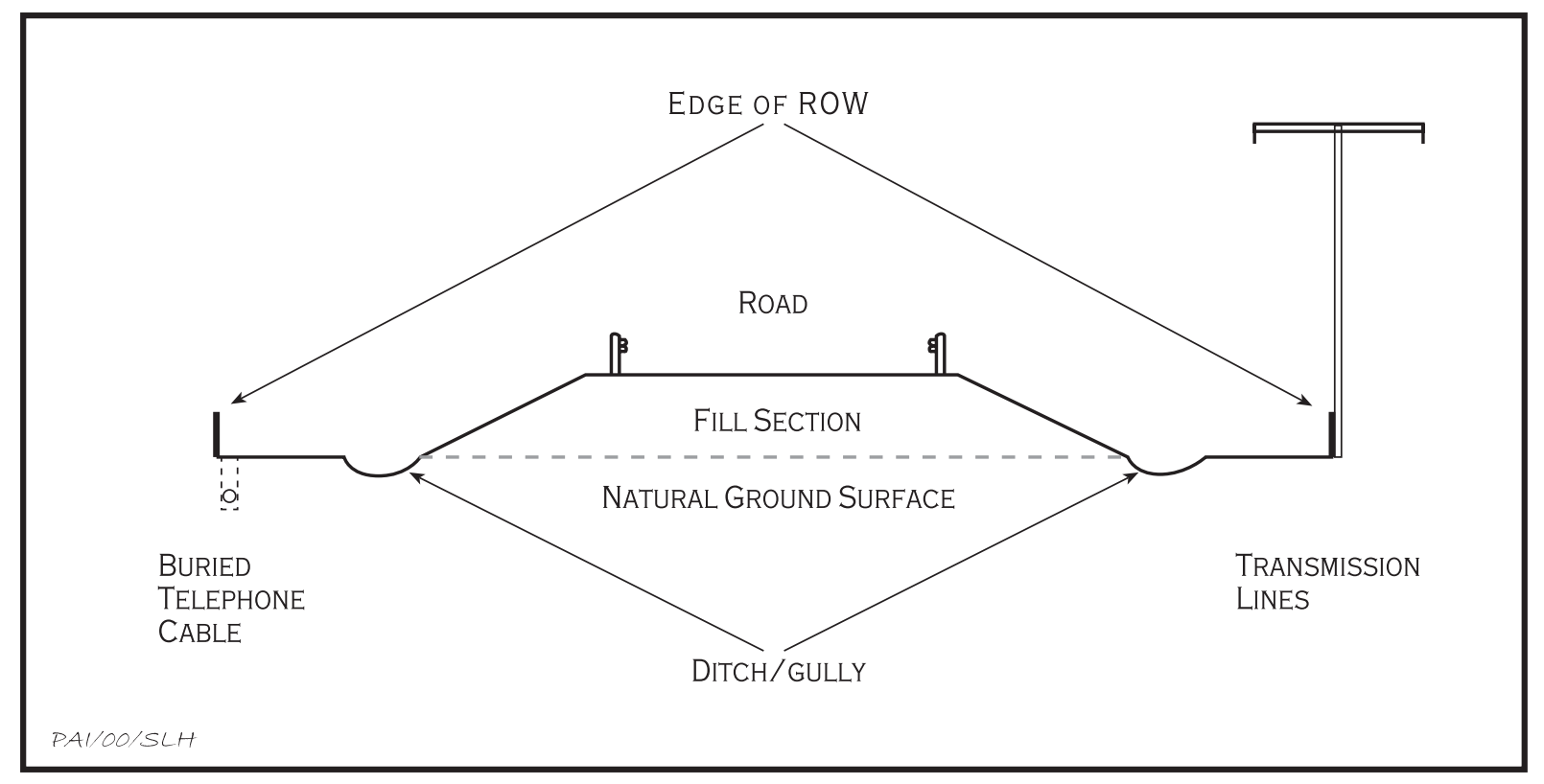

Figure 4. Schematic cross section of a bridge approach showing common disturbance factors.

sections extended at least several meters beyond the edges of the pavement, in some cases occupying as much as three-quarters of the existing right of way. It is difficult to quantify how much disturbance is associated with the placement of fill sections, but it is assumed that at least the upper $0.5 \mathrm{~m}$ of sediment beneath and adjacent to fill sections is disturbed by heavy machinery during construction and subsequently by compaction. Presumably, the larger the fill section, the deeper the disturbance.

In most cases, fill sections were bordered on both sides by shallow drainage ditches (see Table 2). These usually were less than $1 \mathrm{~m}$ deep, and often less than $0.5 \mathrm{~m}$, and they were up to several meters wide. Most were covered by vegetation and thus did not offer any subsurface visibility, but a few that recently had been maintained exposed subsurface deposits. Better exposures typically were provided by gully erosion, which occurred often in the bottoms of ditches running along the edges of fill sections and breaching the creek banks. In many cases, such gullies were present at one or more corners of a bridge, often extending to depths of $1 \mathrm{~m}$ or more (see Table 2).

The fourth kind of disturbance observed consistently was underground utilities. These were present in most project areas, with the most common kind being buried telephone and/or fiber optic lines (see Table 2). These almost always were at one or both edges of the existing right of way and were marked by signs or areas of recent disturbance from placement of the lines. Based on the extent of the recent disturbance, it appears that trenching for these lines usually had disrupted an area $0.5 \mathrm{~m}$ or less in width. Presumably, they vary in depth, with most probably being no deeper than $1 \mathrm{~m}$. More-extensive disturbance probably is associated with other kinds of underground utilities, including water lines, sewer lines, storm drains, and gas pipelines. These were not as ubiquitous as telephone and fiber optic lines, although some of these (especially water lines) may not be marked with signs as consistently as telephone and fiber optic lines.

A variety of other disturbance factors were noted less frequently (see Table 2). These included the following: constructed earthen berms to control runoff or creek flooding; severe erosion of creek banks; flood scouring; push piles from minor earthmoving; road cutting and erosion associated with the use of low-water crossings adjacent to impassable bridges; the placement of fill piles; the 
Table 2. Summary of existing impacts by work order

\begin{tabular}{|c|c|c|c|c|c|c|c|}
\hline $\begin{array}{l}\text { Work } \\
\text { Order }\end{array}$ & County & Project & Fill Sections & Ditches & Gullies & $\begin{array}{l}\text { Underground } \\
\text { Utilities }\end{array}$ & Other \\
\hline 1 & McLennan & $\begin{array}{l}\text { Impact Evaluation; } \\
\text { CR } 345 \text { at Tennant } \\
\text { Branch }\end{array}$ & 1 fill section $1 \mathrm{~m}$ thick & $\begin{array}{l}1 \text { ditch } 2 \text { m deep } \\
1 \text { ditch }<1 \text { m deep }\end{array}$ & & telephone line & \\
\hline 2 & Coryell & $\begin{array}{l}\text { Survey with } \\
\text { Geoarcheological } \\
\text { Assessment; CR } 213 \\
\text { at Coryell Creek }\end{array}$ & 2 fill sections $1 \mathrm{~m}$ thick & 4 ditches $<1$ m deep & 1 gully $1.5-2.0$ m deep & telephone line & $\begin{array}{l}\text { earthen berm; } \\
\text { push piles; low- } \\
\text { water crossing }\end{array}$ \\
\hline \multirow[t]{10}{*}{3} & Hunt & $\begin{array}{l}\text { Impact Evaluation; } \\
\text { SH } 66 \text { at Payne Creek }\end{array}$ & $\begin{array}{l}2 \text { fill sections 1-2 m } \\
\text { thick }\end{array}$ & 2 ditches $\measuredangle 0.5$ m deep & 2 gullies 1 m deep & & $\begin{array}{l}\text { adjacent railroad } \\
\text { bed }\end{array}$ \\
\hline & Hunt & $\begin{array}{l}\text { Impact Evaluation; SH } \\
66 \text { at Brushy Creek }\end{array}$ & $\begin{array}{l}2 \text { fill sections } 1-2 \mathrm{~m} \\
\text { thick }\end{array}$ & $\begin{array}{l}1 \text { ditch }<1 \text { m deep } \\
1 \text { ditch } 1-2 \text { m deep }\end{array}$ & $\begin{array}{l}1 \text { gully } 1.5-2.0 \text { m deep } \\
1 \text { gully } 3 \text { m deep } \\
1 \text { gully } 2 \text { m deep }\end{array}$ & telephone line & $\begin{array}{l}\text { adjacent railroad } \\
\text { bed }\end{array}$ \\
\hline & Hunt & $\begin{array}{l}\text { Impact Evaluation; } \\
\text { SH } 66 \text { at West Caddo } \\
\text { Creek slough }\end{array}$ & $\begin{array}{l}2 \text { fill sections } 1-2 \mathrm{~m} \\
\text { thick }\end{array}$ & 2 ditches $\measuredangle 0.5 \mathrm{~m}$ deep & 1 gully 1-2 m deep & 2 fiber optic lines & $\begin{array}{l}\text { adjacent railroad } \\
\text { bed }\end{array}$ \\
\hline & Hunt & $\begin{array}{l}\text { Impact Evaluation; } \\
\text { SH } 66 \text { at West Caddo } \\
\text { Creek }\end{array}$ & 2 fill sections $2 \mathrm{~m}$ thick & 2 ditches $<1$ m deep & & 2 fiber optic lines & $\begin{array}{l}\text { adjacent railroad } \\
\text { bed }\end{array}$ \\
\hline & Hunt & $\begin{array}{l}\text { Impact Evaluation; } \\
\text { SH } 66 \text { at West Caddo } \\
\text { Creek slough }\end{array}$ & $\begin{array}{l}2 \text { fill sections } 1-2 \mathrm{~m} \\
\text { thick }\end{array}$ & & 1 gully $\varangle 0.5$ m deep & 2 fiber optic lines & $\begin{array}{l}\text { adjacent railroad } \\
\text { bed }\end{array}$ \\
\hline & Hunt & $\begin{array}{l}\text { Impact Evaluation; } \\
\text { SH } 66 \text { West Caddo } \\
\text { Creek tributary }\end{array}$ & 2 fill sections $1 \mathrm{~m}$ thick & 4 ditches $\measuredangle 0.5$ m deep & & 2 fiber optic lines & $\begin{array}{l}\text { adjacent railroad } \\
\text { bed; fill pile }\end{array}$ \\
\hline & Hunt & $\begin{array}{l}\text { Impact Evaluation; } \\
\text { SH } 66 \text { at EIm Creek }\end{array}$ & $\begin{array}{l}2 \text { fill sections } 1.5 \mathrm{~m} \\
\text { thick }\end{array}$ & 4 ditches $\measuredangle 0.5$ m deep & & 2 fiber optic lines & $\begin{array}{l}\text { adjacent railroad } \\
\text { bed; spoil piles }\end{array}$ \\
\hline & Hunt & $\begin{array}{l}\text { Impact Evaluation; } \\
\text { SH } 66 \text { at East Caddo } \\
\text { Creek slough }\end{array}$ & $\begin{array}{l}2 \text { fill sections } 1.5-2.0 \mathrm{~m} \\
\text { thick }\end{array}$ & 1 ditch $\varangle 0.5 \mathrm{~m}$ deep & 1 gully 1 m deep & fiber optic line & $\begin{array}{l}\text { adjacent railroad } \\
\text { bed; spoil piles }\end{array}$ \\
\hline & Hunt & $\begin{array}{l}\text { Impact Evaluation; } \\
\text { SH } 66 \text { at East Caddo } \\
\text { Creek }\end{array}$ & $\begin{array}{l}2 \text { fill sections } 1.5-2.0 \mathrm{~m} \\
\text { thick }\end{array}$ & 1 ditch $0.5-1.0$ m deep & & fiber optic line & $\begin{array}{l}\text { adjacent railroad } \\
\text { bed }\end{array}$ \\
\hline & Hunt & $\begin{array}{l}\text { Impact Evaluation; SH } \\
66 \text { at Block Branch }\end{array}$ & $\begin{array}{l}2 \text { fill sections } 1.5-2.0 \mathrm{~m} \\
\text { thick }\end{array}$ & 1 ditch $\varangle 0.5$ m deep & & $\begin{array}{l}1 \text { fiber optic line } \\
1 \text { telephone line }\end{array}$ & $\begin{array}{l}\text { adjacent rail road } \\
\text { bed and stock tank }\end{array}$ \\
\hline
\end{tabular}


Table 2, continued

\begin{tabular}{|c|c|c|c|c|c|c|c|}
\hline $\begin{array}{l}\text { Work } \\
\text { Order }\end{array}$ & County & Project & Fill Sections & Ditches & Gullies & $\begin{array}{l}\text { Underground } \\
\text { Utilities }\end{array}$ & Other \\
\hline 4 & Tarrant & $\begin{array}{l}\text { Survey; Enon Ave. at } \\
\text { Everman Cemetery }\end{array}$ & & 1 ditch $\measuredangle 0.5$ m deep & & telephone line & $\begin{array}{l}\text { adjacent ceme- } \\
\text { tery landscaping }\end{array}$ \\
\hline \multirow[t]{3}{*}{5} & Ellis & $\begin{array}{l}\text { I mpact Evaluation; } \\
\text { FM } 66 \text { at South Prong } \\
\text { Creek }\end{array}$ & 2 fill sections & 4 ditches $<1$ m deep & 4 gullies $\varangle 0.5 \mathrm{~m}$ deep & 2 tel ephone lines & \\
\hline & Ellis & $\begin{array}{l}\text { Impact Evaluation; } \\
\text { FM } 813 \text { at Red Oak } \\
\text { Creek }\end{array}$ & 2 fill sections & 4 ditches $<1$ m deep & & telephone line & bank erosion \\
\hline & Kaufman & $\begin{array}{l}\text { Impact Evaluation; } \\
\text { Colquitt Rd. at } \\
\text { Bachel or Creek }\end{array}$ & & 4 ditches $<1$ m deep & 3 gullies $\varangle 0.5 \mathrm{~m}$ deep & $\begin{array}{l}\text { water line } \\
\text { sewer line } \\
\text { telephone line }\end{array}$ & \\
\hline 6 & Upshur & $\begin{array}{l}\text { Survey; SH } 155 \text { at } \\
\text { Little Cypress Creek }\end{array}$ & $\begin{array}{l}4 \text { fill sections } 2-3 \mathrm{~m} \\
\text { thick }\end{array}$ & & & gas pipeline & $\begin{array}{l}\text { gravel access } \\
\text { road }\end{array}$ \\
\hline \multirow[t]{3}{*}{7} & Grayson & $\begin{array}{l}\text { I mpact Evaluation; } \\
\text { U.S. Hwy } 377 \text { at } \\
\text { Sandy Creek }\end{array}$ & $\begin{array}{l}2 \text { fill sections 3-4 m } \\
\text { thick }\end{array}$ & 1 ditch $\measuredangle 0.5$ m deep & & & bank erosion \\
\hline & Grayson & $\begin{array}{l}\text { I mpact Evaluation; } \\
\text { U.S. Hwy } 377 \text { at } \\
\text { Brushy Creek }\end{array}$ & $\begin{array}{l}2 \text { fill sections } 2-3 \mathrm{~m} \\
\text { thick }\end{array}$ & 1 ditch $\varangle 0.5 \mathrm{~m}$ deep & & water line & bank erosion \\
\hline & Grayson & $\begin{array}{l}\text { Impact Evaluation; } \\
\text { U.S. Hwy } 377 \text { at Red } \\
\text { Branch }\end{array}$ & $\begin{array}{l}2 \text { fill sections 1-2 m } \\
\text { thick }\end{array}$ & 2 ditches $\measuredangle 0.5$ m deep & & telephone line & bank erosion \\
\hline 8 & McLennan & $\begin{array}{l}\text { Survey with Geoarch- } \\
\text { eological Assessment; } \\
\text { Loop } 340 \text { at the Brazos } \\
\text { River }\end{array}$ & $\begin{array}{l}\text { multiple fill sections } \\
1.5-6.0 \text { m thick }\end{array}$ & $\begin{array}{l}\text { numerous ditches } 0.5- \\
4.0 \text { m deep }\end{array}$ & & $\begin{array}{l}\text { water line } \\
\text { fiber optic lines } \\
2 \text { gas pipelines }\end{array}$ & $\begin{array}{l}\text { gravel access roads } \\
\text { and driveways on } \\
\text { fill with culverts; } \\
\text { borrow pits }\end{array}$ \\
\hline 9 & Bell & $\begin{array}{l}\text { Survey; FM } 439 \text { at } \\
\text { North Nolan Creek }\end{array}$ & & 1 ditch $\measuredangle 0.5$ m deep & & & push piles \\
\hline \multirow[t]{2}{*}{10} & Hunt & $\begin{array}{l}\text { Survey; SH } 66 \text { at EIm } \\
\text { Creek }\end{array}$ & $\begin{array}{l}2 \text { fill sections } 1.5 \mathrm{~m} \\
\text { thick }\end{array}$ & 2 ditches $0.5 \mathrm{~m}$ deep & & fiber optic line & old railroad bed \\
\hline & & $\begin{array}{l}\text { Survey; SH } 66 \text { at East } \\
\text { Caddo Creek }\end{array}$ & $\begin{array}{l}2 \text { fill sections } 1.5-2.0 \mathrm{~m} \\
\text { thick }\end{array}$ & 1 ditch 0.5 m deep & & fiber optic line & old railroad bed \\
\hline
\end{tabular}


Table 2, continued

\begin{tabular}{|c|c|c|c|c|c|c|c|}
\hline $\begin{array}{l}\text { Work } \\
\text { Order }\end{array}$ & County & Project & Fill Sections & Ditches & Gullies & $\begin{array}{l}\text { Underground } \\
\text { Utilities }\end{array}$ & Other \\
\hline \multirow[t]{4}{*}{11} & Hunt & $\begin{array}{l}\text { Impact Evaluation; } \\
\text { CR } 589 \text { at Pecan } \\
\text { Branch }\end{array}$ & $\begin{array}{l}2 \text { fill sections } \varangle 0.5 \mathrm{~m} \\
\text { thick }\end{array}$ & 4 ditches $0.5 \mathrm{~m}$ deep & & water line & \\
\hline & Hunt & $\begin{array}{l}\text { Impact Evaluation; } \\
\text { CR } 793 \text { at Caddo } \\
\text { Creek }\end{array}$ & $\begin{array}{l}2 \text { fill sections } \measuredangle 0.5 \mathrm{~m} \\
\text { thick }\end{array}$ & 4 ditches $0.5 \mathrm{~m}$ deep & 2 gullies $<1$ m deep & & \\
\hline & Hunt & $\begin{array}{l}\text { Impact Evaluation; } \\
\text { CR } 813 \text { at Dry Creek }\end{array}$ & $\begin{array}{l}2 \text { fill sections } \varangle 0.5 \mathrm{~m} \\
\text { thick }\end{array}$ & 2 ditches $0.5 \mathrm{~m}$ deep & 2 gullies $<1.5 \mathrm{~m}$ deep & telephone line & \\
\hline & Hunt & $\begin{array}{l}\text { Impact Evaluation; } \\
\text { CR } 520 \text { at Cowleech } \\
\text { Fork tributary }\end{array}$ & $\begin{array}{l}2 \text { fill sections }<0.5 \mathrm{~m} \\
\text { thick }\end{array}$ & 4 ditches $\measuredangle 0.5$ m deep & 3 gullies <1 m deep & telephone line & \\
\hline \multirow[t]{4}{*}{12} & Fannin & $\begin{array}{l}\text { Impact Evaluation; } \\
\text { FM } 1550 \text { at Davis } \\
\text { Creek }\end{array}$ & 2 fill sections $1 \mathrm{~m}$ thick & 4 ditches $\measuredangle 0.5$ m deep & 2 gullies <1 m deep & $\begin{array}{l}2 \text { telephone/fiber } \\
\text { optic lines }\end{array}$ & \\
\hline & Fannin & $\begin{array}{l}\text { Impact Evaluation; } \\
\text { FM } 1550 \text { at Bralley } \\
\text { Pool Creek }\end{array}$ & $\begin{array}{l}2 \text { fill sections } 1.0-1.5 \mathrm{~m} \\
\text { thick }\end{array}$ & 4 ditches $<1$ m deep & 4 gullies 1-5 m deep & $\begin{array}{l}2 \text { tel ephone/fiber } \\
\text { optic lines }\end{array}$ & \\
\hline & Fannin & $\begin{array}{l}\text { Impact Evaluation; } \\
\text { FM } 1550 \text { at Bledsoe } \\
\text { Creek }\end{array}$ & $\begin{array}{l}2 \text { fill sections } 0.5-1.0 \mathrm{~m} \\
\text { thick }\end{array}$ & 2 ditches $0.5 \mathrm{~m}$ deep & 2 gullies 0.5 m deep & & \\
\hline & Fannin & $\begin{array}{l}\text { Impact Evaluation; } \\
\text { FM } 1553 \text { at Freeman } \\
\text { Creek }\end{array}$ & $\begin{array}{l}2 \text { fill sections } 0.5-1.0 \mathrm{~m} \\
\text { thick }\end{array}$ & 4 ditches $0.5 \mathrm{~m}$ deep & 4 gullies 1 m deep & & \\
\hline \multirow[t]{2}{*}{13} & Hamilton & $\begin{array}{l}\text { Impact Evaluation; } \\
\text { CR } 311 \text { at Cowhouse } \\
\text { Creek }\end{array}$ & $\begin{array}{l}1 \text { fill section } 1-3 \mathrm{~m} \\
\text { thick }\end{array}$ & 1 ditch 0.5 m deep & 1 large gully & & $\begin{array}{l}\text { extensive bank } \\
\text { erosion; push } \\
\text { piles }\end{array}$ \\
\hline & Hamilton & $\begin{array}{l}\text { Survey; CR } 168 \text { at the } \\
\text { Leon River }\end{array}$ & $\begin{array}{l}1 \text { fill section } 0.5 \mathrm{~m} \\
\text { thick }\end{array}$ & & & fiber optic line & $\begin{array}{l}\text { extensive bank } \\
\text { erosion; flood } \\
\text { scouring }\end{array}$ \\
\hline 14 & Upshur & $\begin{array}{l}\text { Survey; FM } 1002 \text { at } \\
\text { Glade Creek }\end{array}$ & $\begin{array}{l}2 \text { fill sections } 0.5-1.0 \mathrm{~m} \\
\text { thick }\end{array}$ & 2 ditches $<1$ m deep & 1 gully 1 m deep & & $\begin{array}{l}\text { old road bed with } \\
\text { associated ditch }\end{array}$ \\
\hline 15 & Denton & $\begin{array}{l}\text { Impact Evaluation; } \\
\text { FM } 156 \text { at Harriet } \\
\text { Creek }\end{array}$ & $\begin{array}{l}2 \text { fill sections 3-4 m } \\
\text { thick }\end{array}$ & 4 ditches $1-2$ m deep & & fiber optic line & $\begin{array}{l}\text { adjacent railroad } \\
\text { bed }\end{array}$ \\
\hline
\end{tabular}


Table 2, continued

\begin{tabular}{|c|c|c|c|c|c|c|c|}
\hline $\begin{array}{l}\text { Work } \\
\text { Order }\end{array}$ & County & Project & Fill Sections & Ditches & Gullies & $\begin{array}{l}\text { Underground } \\
\text { Utilities }\end{array}$ & Other \\
\hline & Denton & $\begin{array}{l}\text { Impact Evaluation; } \\
\text { FM } 156 \text { at Elizabeth } \\
\text { Creek }\end{array}$ & $\begin{array}{l}2 \text { fill sections } 1-5 \mathrm{~m} \\
\text { thick }\end{array}$ & 4 ditches 1-2 m deep & 1 gully 2 m deep & fiber optic line & $\begin{array}{l}\text { adjacent railroad } \\
\text { bed; push pile }\end{array}$ \\
\hline 16 & - & $\begin{array}{l}\text { Quality Control } \\
\text { Debriefing with TxDOT }\end{array}$ & - & - & - & - & - \\
\hline 17 & Bell & $\begin{array}{l}\text { Impact Evaluation; } \\
\text { Loop } 363 \text { around } \\
\text { Temple }\end{array}$ & $\begin{array}{l}\text { multiple fill sections } 1- \\
4 \mathrm{~m} \text { thick }\end{array}$ & $\begin{array}{l}\text { multiple ditches 1-2 m } \\
\text { deep }\end{array}$ & & $\begin{array}{l}\text { multiple telephone/ } \\
\text { fiber optic lines } \\
\text { water lines } \\
\text { sewer lines } \\
\text { storm drains } \\
\text { electrical lines }\end{array}$ & $\begin{array}{l}\text { adjacent parking } \\
\text { lots, shopping } \\
\text { centers, over- } \\
\text { passes, road cuts, } \\
\text { etc. }\end{array}$ \\
\hline \multirow[t]{7}{*}{18} & Grayson & $\begin{array}{l}\text { Impact Evaluation; } \\
\text { SH } 56 \text { at Post Oak } \\
\text { Creek }\end{array}$ & & & & storm drains & $\begin{array}{l}\text { adjacent parking } \\
\text { lots, sidewalks, } \\
\text { commercial dev- } \\
\text { elopments, etc. }\end{array}$ \\
\hline & Grayson & $\begin{array}{l}\text { I mpact Evaluation; } \\
\text { U.S. H wy } 82 \text { at } \\
\text { Choctaw Creek }\end{array}$ & $\begin{array}{l}2 \text { fill sections } 2.0-2.5 \mathrm{~m} \\
\text { thick }\end{array}$ & & 2 gullies $0.5 \mathrm{~m}$ deep & & \\
\hline & Grayson & $\begin{array}{l}\text { I mpact Evaluation; } \\
\text { U.S. Hwy } 82 \text { at Mill } \\
\text { Creek }\end{array}$ & $\begin{array}{l}2 \text { fill sections } 2-3 \mathrm{~m} \\
\text { thick }\end{array}$ & 1 ditch $0.5 \mathrm{~m}$ deep & 4 gullies $0.5 \mathrm{~m}$ deep & telephone line & road cut \\
\hline & Grayson & $\begin{array}{l}\text { Impact Evaluation; } \\
\text { FM } 902 \text { at Range } \\
\text { Creek }\end{array}$ & $\begin{array}{l}2 \text { fill sections } 2-3 \mathrm{~m} \\
\text { thick }\end{array}$ & 4 ditches $0.5 \mathrm{~m}$ deep & & & $\begin{array}{l}\text { push piles; bank } \\
\text { erosion }\end{array}$ \\
\hline & Grayson & $\begin{array}{l}\text { Impact Evaluation; } \\
\text { Whitaker Rd. at West } \\
\text { Prong of Whites Creek }\end{array}$ & $\begin{array}{l}2 \text { fill sections } 0.5 \mathrm{~m} \\
\text { thick }\end{array}$ & 4 ditches $0.5 \mathrm{~m}$ deep & 5 gullies $<1$ m deep & telephone line & push piles \\
\hline & Grayson & $\begin{array}{l}\text { Impact Evaluation; } \\
\text { CR } 194 \text { at Mustang } \\
\text { Creek }\end{array}$ & $\begin{array}{l}2 \text { fill sections } 0.5 \mathrm{~m} \\
\text { thick }\end{array}$ & 3 ditches $0.5 \mathrm{~m}$ deep & 3 gullies 1-2 m deep & & $\begin{array}{l}\text { adjacent stock } \\
\text { tanks }\end{array}$ \\
\hline & Grayson & $\begin{array}{l}\text { I mpact Evaluation; N. } \\
\text { Lincoln Park Rd. at } \\
\text { West Prong of Sister } \\
\text { Grove Creek }\end{array}$ & $\begin{array}{l}2 \text { fill sections } 0.5 \mathrm{~m} \\
\text { thick }\end{array}$ & 4 ditches $0.5 \mathrm{~m}$ deep & 1 gully $<1$ m deep & telephone line & $\begin{array}{l}\text { adjacent push } \\
\text { piles }\end{array}$ \\
\hline
\end{tabular}


Table 2, continued

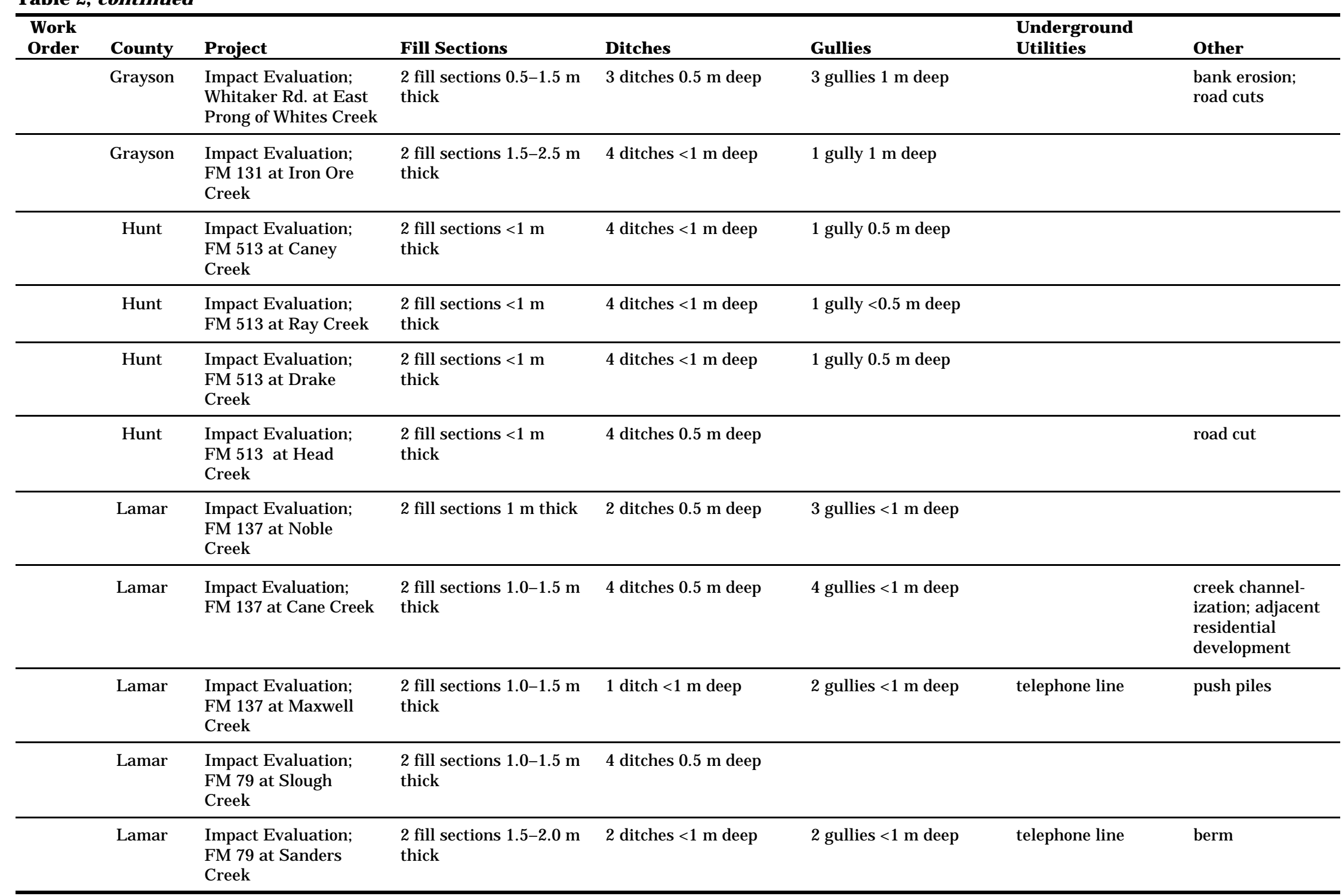


Table 2, continued

\begin{tabular}{|c|c|c|c|c|c|c|c|}
\hline $\begin{array}{l}\text { Work } \\
\text { Order }\end{array}$ & County & Project & Fill Sections & Ditches & Gullies & $\begin{array}{l}\text { Underground } \\
\text { Utilities }\end{array}$ & Other \\
\hline \multirow[t]{11}{*}{19} & Bowie & $\begin{array}{l}\text { Survey; SH } 8 \text { at } \\
\text { Wright Patman Lake }\end{array}$ & $\begin{array}{l}\text { fill sections/causeways } \\
2-9 \text { m thick }\end{array}$ & ditches $1 \mathrm{~m}$ deep & & fiber optic line & $\begin{array}{l}\text { park entrance } \\
\text { road }\end{array}$ \\
\hline & Franklin & $\begin{array}{l}\text { Impact Evaluation; } \\
\text { CR } 130 \text { at Cobb J ones } \\
\text { Creek }\end{array}$ & $\begin{array}{l}2 \text { fill sections } 0.5 \mathrm{~m} \\
\text { thick }\end{array}$ & 4 ditches $0.5 \mathrm{~m}$ deep & $\begin{array}{l}4 \text { gullies } 1.0-1.5 \mathrm{~m} \\
\text { deep }\end{array}$ & telephone line & \\
\hline & Harrison & $\begin{array}{l}\text { Impact Evaluation; } \\
\text { SH } 154 \text { in Marshall }\end{array}$ & fill sections $0.5 \mathrm{~m}$ thick & ditches $<1$ m deep & & $\begin{array}{l}\text { telephone lines } \\
\text { water lines } \\
\text { sewer lines } \\
\text { storm drains }\end{array}$ & $\begin{array}{l}\text { road cuts; bull- } \\
\text { dozing; adjacent } \\
\text { development }\end{array}$ \\
\hline & Hopkins & $\begin{array}{l}\text { I mpact Evaluation; } \\
\text { IH } 30 \text { frontage road at } \\
\text { Rock Creek }\end{array}$ & $\begin{array}{l}2 \text { fill sections } 1.5 \text { m } \\
\text { thick; adjacent IH } 30 \\
\text { fill sections }\end{array}$ & 2 ditches $0.5 \mathrm{~m}$ deep & $\begin{array}{l}2 \text { gullies } 0.5-2.0 \mathrm{~m} \\
\text { deep }\end{array}$ & telephone line & $\begin{array}{l}\text { gravel access } \\
\text { road }\end{array}$ \\
\hline & & $\begin{array}{l}\text { I mpact Evaluation; } \\
\text { IH } 30 \text { frontage road at } \\
\text { Caney Creek }\end{array}$ & $\begin{array}{l}2 \text { fill sections } 2 \text { m thick; } \\
\text { adjacent IH } 30 \text { fill } \\
\text { sections }\end{array}$ & & & telephone line & $\begin{array}{l}\text { berms; borrow } \\
\text { pits }\end{array}$ \\
\hline & & $\begin{array}{l}\text { Impact Evaluation; } \\
\text { CR } 596 \text { at White Oak } \\
\text { Creek }\end{array}$ & $\begin{array}{l}2 \text { fill sections }<1 \mathrm{~m} \\
\text { thick }\end{array}$ & 4 ditches $0.5 \mathrm{~m}$ deep & 4 gullies 1 m deep & & push piles \\
\hline & & $\begin{array}{l}\text { Impact Evaluation; } \\
\text { CR } 572 \text { at Kennedy } \\
\text { Creek }\end{array}$ & $\begin{array}{l}2 \text { fill sections } 0.5 \mathrm{~m} \\
\text { thick }\end{array}$ & & 3 gullies $<1$ m deep & & \\
\hline & & $\begin{array}{l}\text { Impact Evaluation; } \\
\text { bridge replacement on } \\
\text { CR } 271 \text { at Running } \\
\text { Creek }\end{array}$ & $\begin{array}{l}2 \text { fill sections }<0.5 \mathrm{~m} \\
\text { thick }\end{array}$ & & $\begin{array}{l}4 \text { gullies } 0.5-1.5 \mathrm{~m} \\
\text { deep }\end{array}$ & & \\
\hline & & $\begin{array}{l}\text { I mpact Evaluation; } \\
\text { bridge replacement on } \\
\text { CR } 387 \text { at Glade Creek }\end{array}$ & $\begin{array}{l}1 \text { fill section } 0.5 \mathrm{~m} \\
\text { thick }\end{array}$ & 2 ditches $<0.5 \mathrm{~m}$ deep & 4 gullies $<1$ m deep & & \\
\hline & Morris & $\begin{array}{l}\text { Impact Evaluation; } \\
\text { FM } 144 \text { at Boggy } \\
\text { Creek }\end{array}$ & $\begin{array}{l}3 \text { fill sections } 1-2 \mathrm{~m} \\
\text { thick }\end{array}$ & 6 ditches $0.5 \mathrm{~m}$ deep & 6 gullies 1 m deep & telephone line & \\
\hline & Panola & $\begin{array}{l}\text { Impact Evaluation; } \\
\text { U.S. H wy } 79 \text { at the } \\
\text { Sabine River }\end{array}$ & $\begin{array}{l}3 \text { fill sections } 2-4 \mathrm{~m} \\
\text { thick }\end{array}$ & 6 ditches 1-2 m deep & & & $\begin{array}{l}\text { earthmoving; fill } \\
\text { piles; gravel access } \\
\text { roads; road cuts }\end{array}$ \\
\hline
\end{tabular}


Table 2, continued

\begin{tabular}{|c|c|c|c|c|c|c|c|}
\hline $\begin{array}{l}\text { Work } \\
\text { Order }\end{array}$ & County & Project & Fill Sections & Ditches & Gullies & $\begin{array}{l}\text { Underground } \\
\text { Utilities }\end{array}$ & Other \\
\hline & & $\begin{array}{l}\text { Impact Evaluation; } \\
\text { FM } 1186 \text { at J ackson } \\
\text { Creek }\end{array}$ & 2 fill sections $2 \mathrm{~m}$ thick & 4 ditches $0.5 \mathrm{~m}$ deep & 4 gullies 0.5 m deep & & road cuts \\
\hline & & $\begin{array}{l}\text { Impact Evaluation; } \\
\text { FM } 124 \text { at Buckner } \\
\text { Creek }\end{array}$ & $\begin{array}{l}2 \text { fill sections }<1 \mathrm{~m} \\
\text { thick }\end{array}$ & 4 ditches $0.5 \mathrm{~m}$ deep & 4 gullies 1 m deep & gas pipeline & \\
\hline & & $\begin{array}{l}\text { Impact Evaluation; } \\
\text { FM } 124 \text { at Caney } \\
\text { Creek }\end{array}$ & 2 fill sections $2 \mathrm{~m}$ thick & 4 ditches $0.5 \mathrm{~m}$ deep & 4 gullies 0.5 m deep & gas pipeline & \\
\hline & Rains & $\begin{array}{l}\text { Impact Evaluation; } \\
\text { SH } 19 \text { at the Sabine } \\
\text { River }\end{array}$ & 2 fill sections $5 \mathrm{~m}$ thick & ditches $0.5 \mathrm{~m}$ deep & gullies 1 m deep & 2 telephone lines & road cuts \\
\hline 20 & McLennan & $\begin{array}{l}\text { Impact Evaluation; } \\
\text { SH } 317 \text { at Wasp } \\
\text { Creek }\end{array}$ & $\begin{array}{l}2 \text { fill sections } 2.5-3.0 \mathrm{~m} \\
\text { thick }\end{array}$ & 4 ditches $<1$ m deep & & & $\begin{array}{l}\text { adjacent railroad } \\
\text { bed }\end{array}$ \\
\hline \multirow[t]{2}{*}{21} & Dallas & $\begin{array}{l}\text { Impact Evaluation; } \\
\text { Preston Rd. in Dallas }\end{array}$ & $\begin{array}{l}\text { fill sections 3-14 m } \\
\text { thick }\end{array}$ & & & $\begin{array}{l}\text { storm drains } \\
\text { fiber optic lines } \\
\text { gas lines }\end{array}$ & $\begin{array}{l}\text { adjacent railroad } \\
\text { bed, highway } \\
\text { interchange, and } \\
\text { frontage roads; } \\
\text { fill pile }\end{array}$ \\
\hline & Kaufman & $\begin{array}{l}\text { Impact Evaluation; } \\
\text { U.S. Hwy } 175 \text { at Cedar } \\
\text { Creek Reservoir }\end{array}$ & $\begin{array}{l}\text { large causeway over } \\
\text { lake }\end{array}$ & ditches 1-2 m deep & & telephone lines & road cuts \\
\hline 22 & Harrison & $\begin{array}{l}\text { Impact Evaluation; } \\
\text { FM } 31 \text { at Quapaw } \\
\text { Creek }\end{array}$ & $\begin{array}{l}\text { fill sections } 0.5-2.0 \mathrm{~m} \\
\text { thick }\end{array}$ & ditches $<1$ m deep & gullies < $<$ m deep & telephone line & $\begin{array}{l}\text { gravel access } \\
\text { roads }\end{array}$ \\
\hline \multirow[t]{3}{*}{23} & Delta & $\begin{array}{l}\text { Impact Evaluation; CR } \\
106 \text { at J ohns Creek }\end{array}$ & $\begin{array}{l}2 \text { fill sections }<1 \mathrm{~m} \\
\text { thick }\end{array}$ & 4 ditches 1 m deep & & & bank erosion \\
\hline & & $\begin{array}{l}\text { Impact Evaluation; } \\
\text { CR } 128 \text { at West Fork } \\
\text { of J ernigan Creek }\end{array}$ & $\begin{array}{l}2 \text { fill sections } \varangle 0.5 \mathrm{~m} \\
\text { thick }\end{array}$ & 4 ditches $0.5 \mathrm{~m}$ deep & $\begin{array}{l}2 \text { gullies } 1.0-1.5 \text { m } \\
\text { deep }\end{array}$ & & \\
\hline & & $\begin{array}{l}\text { Impact Evaluation; } \\
\text { CR } 218 \text { at Lake Creek }\end{array}$ & & & 2 gullies 1 m deep & telephone line & $\begin{array}{l}\text { road cuts; push } \\
\text { piles }\end{array}$ \\
\hline
\end{tabular}


Table 2, continued

\begin{tabular}{|c|c|c|c|c|c|c|c|}
\hline $\begin{array}{l}\text { Work } \\
\text { Order }\end{array}$ & County & Project & Fill Sections & Ditches & Gullies & $\begin{array}{l}\text { Underground } \\
\text { Utilities }\end{array}$ & Other \\
\hline & & $\begin{array}{l}\text { Impact Evaluation; } \\
\text { CR } 180 \text { at a tributary } \\
\text { of the North Sulphur } \\
\text { River }\end{array}$ & $\begin{array}{l}2 \text { fill sections }<0.5 \mathrm{~m} \\
\text { thick }\end{array}$ & 4 ditches $\measuredangle 0.5 \mathrm{~m}$ deep & $\begin{array}{l}4 \text { gullies } 1.0-1.5 \mathrm{~m} \\
\text { deep }\end{array}$ & & bank erosion \\
\hline & Fannin & $\begin{array}{l}\text { Impact Evaluation; } \\
\text { U.S. Hwy } 82 \text { at Big } \\
\text { Caney Creek }\end{array}$ & $\begin{array}{l}2 \text { fill sections } 2.0-2.5 \mathrm{~m} \\
\text { thick }\end{array}$ & 4 ditches $0.5 \mathrm{~m}$ deep & gullies < 1 m deep & telephone line & push piles \\
\hline & \multirow[t]{4}{*}{ Hunt } & $\begin{array}{l}\text { Impact Evaluation; } \\
\text { CR } 1035 \text { at Hickory } \\
\text { Creek }\end{array}$ & $\begin{array}{l}2 \text { fill sections }<1 \mathrm{~m} \\
\text { thick }\end{array}$ & 4 ditches $0.5 \mathrm{~m}$ deep & 4 gullies 1 m deep & telephone line & $\begin{array}{l}\text { adjacent stock } \\
\text { tank }\end{array}$ \\
\hline & & $\begin{array}{l}\text { Impact Evaluation; } \\
\text { CR } 1032 \text { at a tribu- } \\
\text { tary of Cowleech Fork }\end{array}$ & $\begin{array}{l}2 \text { fill sections } 0.5 \mathrm{~m} \\
\text { thick }\end{array}$ & 4 ditches $0.5 \mathrm{~m}$ deep & $\begin{array}{l}\text { several gullies } 0.5 \text { m } \\
\text { deep }\end{array}$ & & \\
\hline & & $\begin{array}{l}\text { Impact Evaluation; } \\
\text { CR } 3211 \text { at Lake Fork } \\
\text { Creek }\end{array}$ & $\begin{array}{l}2 \text { fill sections } 0.5 \mathrm{~m} \\
\text { thick }\end{array}$ & 4 ditches $0.5 \mathrm{~m}$ deep & 3 gullies 1 m deep & telephone line & \\
\hline & & $\begin{array}{l}\text { Impact Evaluation; } \\
\text { FM } 1563 \text { at the Middle } \\
\text { Sulphur River }\end{array}$ & $\begin{array}{l}2 \text { fill sections } 1.0-1.5 \mathrm{~m} \\
\text { thick }\end{array}$ & 4 ditches $0.5 \mathrm{~m}$ deep & & telephone line & bank erosion \\
\hline & \multirow[t]{2}{*}{ Lamar } & $\begin{array}{l}\text { Impact Evaluation; } \\
\text { 2nd St. in Roxton }\end{array}$ & $\begin{array}{l}2 \text { fill sections } 0.5-1.5 \mathrm{~m} \\
\text { thick }\end{array}$ & 4 ditches $0.5 \mathrm{~m}$ deep & 4 gullies $<1$ m deep & $\begin{array}{l}\text { telephone line; gas } \\
\text { lines; water lines }\end{array}$ & $\begin{array}{l}\text { adjacent residen- } \\
\text { tial devel opment }\end{array}$ \\
\hline & & $\begin{array}{l}\text { Impact Evaluation; } \\
\text { Deport St. in Deport }\end{array}$ & 1 fill section $1 \mathrm{~m}$ thick & 4 ditches $0.5 \mathrm{~m}$ deep & 2 gullies $<1$ m deep & gas pipeline & $\begin{array}{l}\text { creek } \\
\text { channelization }\end{array}$ \\
\hline \multirow[t]{2}{*}{24} & \multirow[t]{2}{*}{ Erath } & $\begin{array}{l}\text { I mpact Evaluation; } \\
\text { CR } 417 \text { at a tributary } \\
\text { of the South Fork of } \\
\text { the North Bosque } \\
\text { River }\end{array}$ & $\begin{array}{l}1 \text { fill section } 0.5 \mathrm{~m} \\
\text { thick }\end{array}$ & 2 ditches $\measuredangle 0.5$ m deep & 2 gullies 2.0-3.5 deep & $\begin{array}{l}\text { telephone line } \\
\text { gas pipeline }\end{array}$ & $\begin{array}{l}\text { push pile; bank } \\
\text { erosion }\end{array}$ \\
\hline & & $\begin{array}{l}\text { I mpact Evaluation; } \\
\text { CR } 230 \text { at a tributary } \\
\text { of Duffau Creek }\end{array}$ & $\begin{array}{l}1 \text { fill section } 1.5 \mathrm{~m} \\
\text { thick }\end{array}$ & & 2 gullies 1-4 m deep & & push pile \\
\hline 25 & Panola & $\begin{array}{l}\text { Survey; FM } 124 \text { at } \\
\text { Buckner Creek }\end{array}$ & $\begin{array}{l}2 \text { fill sections }<1 \mathrm{~m} \\
\text { thick }\end{array}$ & 4 ditches $0.5 \mathrm{~m}$ deep & 4 gullies <1 m deep & gas pipeline & \\
\hline
\end{tabular}


Table 2, continued

\begin{tabular}{|c|c|c|c|c|c|c|c|}
\hline $\begin{array}{l}\text { Work } \\
\text { Order }\end{array}$ & County & Project & Fill Sections & Ditches & Gullies & $\begin{array}{l}\text { Underground } \\
\text { Utilities }\end{array}$ & Other \\
\hline & & $\begin{array}{l}\text { Survey; FM } 124 \text { at } \\
\text { Caney Creek }\end{array}$ & $\begin{array}{l}2 \text { fill sections }<2 \mathrm{~m} \\
\text { thick }\end{array}$ & 5 ditches $0.5 \mathrm{~m}$ deep & & gas pipeline & old channel scars \\
\hline & & $\begin{array}{l}\text { Survey; FM } 10 \text { at Six } \\
\text { Mile Creek }\end{array}$ & $\begin{array}{l}2 \text { fill sections }<2 \mathrm{~m} \\
\text { thick }\end{array}$ & 4 ditches $0.5 \mathrm{~m}$ deep & & $\begin{array}{l}\text { gas pipelines } \\
\text { water line } \\
\text { fiber optic line }\end{array}$ & $\begin{array}{l}\text { road cut; } \\
\text { adjacent clear- } \\
\text { cut areas }\end{array}$ \\
\hline 26 & Morris & $\begin{array}{l}\text { Survey; FM } 144 \text { at } \\
\text { Boggy Creek }\end{array}$ & $\begin{array}{l}3 \text { fill sections } 1-2 \mathrm{~m} \\
\text { thick }\end{array}$ & 6 ditches $0.5 \mathrm{~m}$ deep & 6 gullies 1 m deep & telephone line & \\
\hline \multirow[t]{7}{*}{27} & Fannin & $\begin{array}{l}\text { Impact Evaluation; } \\
\text { CR } 271 \text { at Cooper } \\
\text { Creek }\end{array}$ & & 2 ditches $<1$ m deep & & telephone line & $\begin{array}{l}\text { push piles; bank } \\
\text { erosion }\end{array}$ \\
\hline & & $\begin{array}{l}\text { Impact Evaluation; } \\
\text { CR } 656 \text { at Rock Creek }\end{array}$ & & 1 ditch $\measuredangle 0.5$ m deep & 1 gully $1-2$ m deep & & bank erosion \\
\hline & Red River & $\begin{array}{l}\text { Impact Evaluation; } \\
\text { FM } 909 \text { at Cuthand } \\
\text { Creek }\end{array}$ & $\begin{array}{l}2 \text { fill sections } 4-5 \mathrm{~m} \\
\text { thick }\end{array}$ & & & water line & bank erosion \\
\hline & & $\begin{array}{l}\text { Impact Evaluation; } \\
\text { FM } 909 \text { at Frances } \\
\text { Creek }\end{array}$ & 1 fill section $2 \mathrm{~m}$ thick & & 2 gullies 1-2 m deep & water line & road cuts \\
\hline & & $\begin{array}{l}\text { Impact Evaluation; } \\
\text { FM } 410 \text { at Scatter } \\
\text { Creek }\end{array}$ & $\begin{array}{l}2 \text { fill sections } 1.5-3.0 \mathrm{~m} \\
\text { thick }\end{array}$ & 4 ditches $<1$ m deep & 4 gullies 1-4 m deep & $\begin{array}{l}\text { gas pipeline } \\
\text { telephone line } \\
\text { sewer line }\end{array}$ & $\begin{array}{l}\text { bulldozing; } \\
\text { adjacent residen- } \\
\text { tial development }\end{array}$ \\
\hline & & $\begin{array}{l}\text { Impact Evaluation; } \\
\text { FM } 410 \text { at Wildcat } \\
\text { Creek }\end{array}$ & $\begin{array}{l}2 \text { fill sections } 2-4 \mathrm{~m} \\
\text { thick }\end{array}$ & 4 ditches $\measuredangle 0.5$ m deep & 4 gullies 2 m deep & telephone line & bank erosion \\
\hline & & $\begin{array}{l}\text { Impact Evaluation; } \\
\text { FM } 910 \text { at Cuthand } \\
\text { Creek }\end{array}$ & $\begin{array}{l}2 \text { fill sections } 1.5-3.0 \mathrm{~m} \\
\text { thick }\end{array}$ & 2 ditches $<1$ m deep & 2 gullies $<3$ m deep & water lines & $\begin{array}{l}\text { push pile; old } \\
\text { channel scars }\end{array}$ \\
\hline 28 & Erath & $\begin{array}{l}\text { Survey; CR } 230 \text { at a } \\
\text { tributary of Duffau } \\
\text { Creek }\end{array}$ & $\begin{array}{l}1 \text { fill section } 1.5 \mathrm{~m} \\
\text { thick }\end{array}$ & & 2 gullies 1-4 m deep & & push pile \\
\hline 29 & Collin & $\begin{array}{l}\text { Impact Evaluation; } \\
\text { FM } 545 \text { at Pilot Grove } \\
\text { Creek }\end{array}$ & $\begin{array}{l}4 \text { fill sections } 0.5-2.0 \mathrm{~m} \\
\text { thick }\end{array}$ & 2 ditches $0.5 \mathrm{~m}$ deep & 4 gullies $<1$ m deep & telephone line & $\begin{array}{l}\text { gravel access } \\
\text { roads; berm; road } \\
\text { cut }\end{array}$ \\
\hline
\end{tabular}


Table 2, continued

\begin{tabular}{|c|c|c|c|c|c|c|c|}
\hline $\begin{array}{l}\text { Work } \\
\text { Order }\end{array}$ & County & Project & Fill Sections & Ditches & Gullies & $\begin{array}{l}\text { Underground } \\
\text { Utilities }\end{array}$ & Other \\
\hline & Denton & $\begin{array}{l}\text { Impact Evaluation; } \\
\text { FM } 1173 \text { at North } \\
\text { Hickory Creek }\end{array}$ & $\begin{array}{l}2 \text { fill sections }<2 \mathrm{~m} \\
\text { thick }\end{array}$ & 4 ditches $\measuredangle 0.5$ m deep & 1 gully 0.5 m deep & 2 telephone lines & old channel scars \\
\hline & & $\begin{array}{l}\text { Impact Evaluation; } \\
\text { FM } 1171 \text { north of } \\
\text { Grapevine Lake }\end{array}$ & fill sections $1-8 \mathrm{~m}$ thick & $\begin{array}{l}\text { multiple ditches }<1 \text { m } \\
\text { deep }\end{array}$ & $\begin{array}{l}\text { multiple gullies }<1 \text { m } \\
\text { deep }\end{array}$ & $\begin{array}{l}\text { telephone lines } \\
\text { fiber optic lines } \\
\text { storm drains } \\
\text { gas pipelines } \\
\text { water lines }\end{array}$ & $\begin{array}{l}\text { road cuts; } \\
\text { adjacent residen- } \\
\text { tial and commer- } \\
\text { cial development }\end{array}$ \\
\hline & & $\begin{array}{l}\text { Impact Evaluation; } \\
\text { FM } 1830 \text { at Loving } \\
\text { Branch }\end{array}$ & $\begin{array}{l}2 \text { fill sections } 1.5 \mathrm{~m} \\
\text { thick }\end{array}$ & 1 ditch $<1$ m deep & 1 gully $<1$ m deep & $\begin{array}{l}\text { fiber optic line } \\
\text { sewer line }\end{array}$ & $\begin{array}{l}\text { road cuts; } \\
\text { adjacent stock } \\
\text { pond; adjacent } \\
\text { residential } \\
\text { development }\end{array}$ \\
\hline 30 & - & $\begin{array}{l}\text { Produce synthetic } \\
\text { report }\end{array}$ & - & - & - & - & - \\
\hline \multirow[t]{2}{*}{31} & Hill & $\begin{array}{l}\text { Survey; FM } 744 \text { at } \\
\text { Four Mile Creek }\end{array}$ & $\begin{array}{l}2 \text { fill sections } 1.5-2.0 \mathrm{~m} \\
\text { thick }\end{array}$ & 1 ditch $<1$ m deep & 4 gullies $<1$ m deep & telephone line & \\
\hline & Bell & $\begin{array}{l}\text { Impact Evaluation; } \\
\text { SH } 36 \text { south of } \\
\text { Temple }\end{array}$ & fill sections 1-2 $m$ thick & $\begin{array}{l}\text { multiple ditches } \varangle 0.5 \mathrm{~m} \\
\text { deep }\end{array}$ & $\begin{array}{l}\text { multiple gullies }<1 \mathrm{~m} \\
\text { deep }\end{array}$ & fiber optic lines & $\begin{array}{l}\text { bulldozing; bank } \\
\text { erosion; adjacent } \\
\text { stock tanks; } \\
\text { adjacent erosion } \\
\text { control structures }\end{array}$ \\
\hline \multirow[t]{3}{*}{32} & Cass & $\begin{array}{l}\text { Survey; FM } 250 \text { at } \\
\text { Black Cypress Creek }\end{array}$ & 2 fill sections $2 \mathrm{~m}$ thick & 4 ditches $<1$ m deep & $\begin{array}{l}\text { multiple gullies <1 m } \\
\text { deep }\end{array}$ & gas pipeline & \\
\hline & & $\begin{array}{l}\text { Survey; FM } 250 \text { at } \\
\text { Arbery Branch }\end{array}$ & $\begin{array}{l}2 \text { fill sections } 0.5-1.5 \mathrm{~m} \\
\text { thick }\end{array}$ & 4 ditches $0.5 \mathrm{~m}$ deep & 2 gullies 1 m deep & gas pipeline & \\
\hline & & $\begin{array}{l}\text { Survey; FM } 250 \text { at } \\
\text { Kelly Creek }\end{array}$ & $\begin{array}{l}3 \text { fill sections } 1.0-2.0 \mathrm{~m} \\
\text { thick }\end{array}$ & 2 ditches $0.5 \mathrm{~m}$ deep & $\begin{array}{l}\text { multiple gullies }<1 \mathrm{~m} \\
\text { deep }\end{array}$ & $\begin{array}{l}\text { fiber optic line } \\
\text { telephone line } \\
\text { gas pipeline }\end{array}$ & \\
\hline 33 & $\begin{array}{l}\text { Gregg and } \\
\text { Upshur }\end{array}$ & $\begin{array}{l}\text { Impact Evaluation; } \\
\text { U.S. Hwy } 80 \text { in } \\
\text { Gladewater }\end{array}$ & $\begin{array}{l}1 \text { fill section } 6.5 \mathrm{~m} \text { thick; } \\
1 \text { fill section } 1 \mathrm{~m} \text { thick }\end{array}$ & $\begin{array}{l}\text { multiple ditches }<1 \mathrm{~m} \\
\text { deep }\end{array}$ & $\begin{array}{l}\text { multiple gullies <1 m } \\
\text { deep }\end{array}$ & $\begin{array}{l}\text { sewer lines } \\
\text { gas pipelines } \\
\text { fiber optic lines } \\
\text { water lines }\end{array}$ & $\begin{array}{l}\text { road cuts; adjac- } \\
\text { ent residential } \\
\text { and commercial } \\
\text { devel opment }\end{array}$ \\
\hline
\end{tabular}


Table 2, continued

\begin{tabular}{|c|c|c|c|c|c|c|c|}
\hline $\begin{array}{l}\text { Work } \\
\text { Order }\end{array}$ & County & Project & Fill Sections & Ditches & Gullies & $\begin{array}{l}\text { Underground } \\
\text { Utilities }\end{array}$ & Other \\
\hline & & $\begin{array}{l}\text { Survey; U.S. Hwy } 80 \\
\text { at Glade Creek }\end{array}$ & $\begin{array}{l}2 \text { fill sections 2-3 m } \\
\text { thick }\end{array}$ & 3 ditches $0.5 \mathrm{~m}$ deep & $\begin{array}{l}\text { multiple gullies }<1 \text { m } \\
\text { deep }\end{array}$ & $\begin{array}{l}\text { sewer lines } \\
\text { gas pipelines } \\
\text { fiber optic line }\end{array}$ & $\begin{array}{l}\text { road cuts; } \\
\text { adjacent oil/gas } \\
\text { development }\end{array}$ \\
\hline 34 & Collin & $\begin{array}{l}\text { Survey; FM } 545 \text { at } \\
\text { Pilot Grove Creek }\end{array}$ & $\begin{array}{l}4 \text { fill sections } 0.5-2.0 \mathrm{~m} \\
\text { thick }\end{array}$ & 2 ditches $0.5 \mathrm{~m}$ deep & 4 gullies <1 m deep & telephone line & $\begin{array}{l}\text { gravel access } \\
\text { roads; berm; road } \\
\text { cut }\end{array}$ \\
\hline \multirow[t]{2}{*}{35} & Falls & $\begin{array}{l}\text { Impact Evaluation; } \\
\text { SH } 6 \text { south of Marlin }\end{array}$ & $\begin{array}{l}\text { multiple fill sections } 1- \\
5 \mathrm{~m} \text { thick }\end{array}$ & $\begin{array}{l}\text { multiple ditches }<1.5 \mathrm{~m} \\
\text { deep }\end{array}$ & $\begin{array}{l}\text { multiple gullies }<1 \text { m } \\
\text { deep }\end{array}$ & $\begin{array}{l}\text { telephone line } \\
\text { fiber optic line }\end{array}$ & $\begin{array}{l}\text { old railroad bed; } \\
\text { old road bed; } \\
\text { highway inter- } \\
\text { change; gravel } \\
\text { access road }\end{array}$ \\
\hline & & $\begin{array}{l}\text { Survey with Geoarch- } \\
\text { eological Assessment; } \\
\text { SH } 6 \text { at Big Creek }\end{array}$ & 3 fill sections $7 \mathrm{~m}$ thick & 3 ditches 1 m deep & 2 gullies 1.5 m deep & 2 fiber optic lines & $\begin{array}{l}\text { old railroad bed; } \\
\text { old road bed }\end{array}$ \\
\hline 36 & Coryell & $\begin{array}{l}\text { I mpact Evaluation; FM } \\
107 \text { north of Mother } \\
\text { Neff State Park }\end{array}$ & $\begin{array}{l}4 \text { fill sections } 1-2 \mathrm{~m} \\
\text { thick }\end{array}$ & $\begin{array}{l}\text { multiple ditches } \varangle 0.5 \mathrm{~m} \\
\text { deep }\end{array}$ & $\begin{array}{l}\text { multiple gullies } 0.5 \mathrm{~m} \\
\text { deep }\end{array}$ & $\begin{array}{l}2 \text { telephone lines } \\
\text { gas pipeline }\end{array}$ & $\begin{array}{l}\text { bulldozing; } \\
\text { adjacent residen- } \\
\text { tial development }\end{array}$ \\
\hline \multirow[t]{6}{*}{37} & Hunt & $\begin{array}{l}\text { Impact Evaluation; } \\
\text { FM } 499 \text { at Lynn } \\
\text { Creek }\end{array}$ & $\begin{array}{l}2 \text { fill sections } 1-5 \mathrm{~m} \\
\text { thick }\end{array}$ & 3 ditches $\measuredangle 0.5 \mathrm{~m}$ deep & 2 gullies $<1$ m deep & $\begin{array}{l}2 \text { telephone lines } \\
1 \text { water line }\end{array}$ & \\
\hline & & $\begin{array}{l}\text { Impact Evaluation; } \\
\text { SH } 224 \text { at the Sabine } \\
\text { River }\end{array}$ & 6 fill sections $6 \mathrm{~m}$ thick & & & & \\
\hline & & $\begin{array}{l}\text { Impact Evaluation; } \\
\text { SH } 34 \text { at the South } \\
\text { Sulphur River }\end{array}$ & $\begin{array}{l}2 \text { fill sections } 2-6 \mathrm{~m} \\
\text { thick }\end{array}$ & & & $\begin{array}{l}1 \text { telephone line } \\
1 \text { fiber optic line }\end{array}$ & \\
\hline & & $\begin{array}{l}\text { Impact Evaluation; } \\
\text { CR } 522 \text { at the Sabine } \\
\text { River }\end{array}$ & $\begin{array}{l}2 \text { fill sections } 0.5 \mathrm{~m} \\
\text { thick }\end{array}$ & 4 ditches $<1$ m deep & & & \\
\hline & & $\begin{array}{l}\text { Impact Evaluation; } \\
\text { CR } 523 \text { at Lake Fork } \\
\text { Creek }\end{array}$ & $\begin{array}{l}2 \text { fill sections } 0.5 \mathrm{~m} \\
\text { thick }\end{array}$ & $\begin{array}{l}4 \text { ditches } 0.5-1.5 \mathrm{~m} \\
\text { deep }\end{array}$ & 2 gullies 2 m deep & $\begin{array}{l}1 \text { telephone line } \\
1 \text { gas pipeline }\end{array}$ & \\
\hline & & $\begin{array}{l}\text { Impact Evaluation; } \\
\text { FM } 816 \text { at Spring } \\
\text { Creek }\end{array}$ & 4 fill sections $1 \mathrm{~m}$ thick & 2 ditches & $\begin{array}{l}2 \text { gullies } 0.5-3.0 \mathrm{~m} \\
\text { deep }\end{array}$ & 1 telephone line & bank erosion \\
\hline
\end{tabular}


Table 2, continued

\begin{tabular}{|c|c|c|c|c|c|c|c|}
\hline $\begin{array}{l}\text { Work } \\
\text { Order }\end{array}$ & County & Project & Fill Sections & Ditches & Gullies & $\begin{array}{l}\text { Underground } \\
\text { Utilities }\end{array}$ & Other \\
\hline & Lamar & $\begin{array}{l}\text { Impact Evaluation; } \\
\text { FM } 2122 \text { at Maxwell } \\
\text { Creek }\end{array}$ & $\begin{array}{l}2 \text { fill sections } 2.5 \mathrm{~m} \\
\text { thick }\end{array}$ & 4 ditches $<1$ m deep & $\begin{array}{l}3 \text { gullies } 2.5-3.0 \text { m } \\
\text { deep }\end{array}$ & 1 telephone line & \\
\hline 38 & Wise & $\begin{array}{l}\text { Impact Evaluation; } \\
\text { U.S. Hwy } 380 \text { east of } \\
\text { Decatur }\end{array}$ & $\begin{array}{l}\text { multiple fill sections } 1- \\
8 \mathrm{~m} \text { thick }\end{array}$ & & $\begin{array}{l}\text { multiple gullies } 0.5- \\
2.0 \text { m deep }\end{array}$ & $\begin{array}{l}\text { gas pipeline } \\
\text { fiber optic line } \\
\text { telephone line }\end{array}$ & fill piles \\
\hline \multirow[t]{9}{*}{39} & Bell & $\begin{array}{l}\text { Impact Evaluation; } \\
\text { SH } 36 \text { at the Leon } \\
\text { River }\end{array}$ & 2 fill sections $7 \mathrm{~m}$ thick & 4 ditches $1 \mathrm{~m}$ deep & & $\begin{array}{l}1 \text { telephone/fiber } \\
\text { optic line }\end{array}$ & park access roads \\
\hline & & $\begin{array}{l}\text { Impact Evaluation; } \\
\text { SH } 95 \text { at the Little } \\
\text { River }\end{array}$ & 2 fill sections $4 \mathrm{~m}$ thick & & & $\begin{array}{l}1 \text { telephone/fiber } \\
\text { optic line }\end{array}$ & $\begin{array}{l}\text { old highway bed; } \\
\text { channel cutting; } \\
\text { drag strip }\end{array}$ \\
\hline & & $\begin{array}{l}\text { Impact Evaluation; } \\
\text { CR } 382 \text { at the Little } \\
\text { River }\end{array}$ & 2 fill sections $2 \mathrm{~m}$ thick & 2 ditches $1 \mathrm{~m}$ deep & & & $\begin{array}{l}\text { bank erosion; } \\
\text { gravel piles }\end{array}$ \\
\hline & Hamilton & $\begin{array}{l}\text { Impact Evaluation; } \\
\text { CR } 284 \text { at Alexander } \\
\text { Creek }\end{array}$ & $\begin{array}{l}2 \text { fill sections } 2.5 \mathrm{~m} \\
\text { thick }\end{array}$ & & $\begin{array}{l}\text { multiple gullies } 0.5 \text { m } \\
\text { deep }\end{array}$ & 1 telephone line & $\begin{array}{l}\text { adjacent low- } \\
\text { water crossing; } \\
\text { bulldozing }\end{array}$ \\
\hline & & $\begin{array}{l}\text { Impact Evaluation; } \\
\text { CR } 296 \text { at Bear Creek }\end{array}$ & & 1 ditch 1 m deep & & 1 telephone line & $\begin{array}{l}\text { adjacent low- } \\
\text { water crossing; } \\
\text { bank erosion; old } \\
\text { railroad bed }\end{array}$ \\
\hline & & $\begin{array}{l}\text { Impact Evaluation; } \\
\text { CR } 294 \text { at Alex } \\
\text { Branch }\end{array}$ & 2 fill sections $2 \mathrm{~m}$ thick & & 1 gully $<1$ m deep & 1 telephone line & road cut \\
\hline & & $\begin{array}{l}\text { Impact Evaluation; } \\
\text { CR } 260 \text { at the North } \\
\text { Bosque River tributary }\end{array}$ & $\begin{array}{l}2 \text { fill sections }<1 \mathrm{~m} \\
\text { thick }\end{array}$ & 2 ditches $\measuredangle 0.5$ m deep & $\begin{array}{l}\text { multiple gullies }<0.5 \mathrm{~m} \\
\text { deep }\end{array}$ & 1 telephone line & push piles \\
\hline & Hill & $\begin{array}{l}\text { Impact Evaluation; } \\
\text { CR } 469 \text { at Cottonwood } \\
\text { Creek }\end{array}$ & $\begin{array}{l}2 \text { fill sections } 1.5 \mathrm{~m} \\
\text { thick }\end{array}$ & & $\begin{array}{l}\text { multiple gullies 1-2 m } \\
\text { deep }\end{array}$ & 1 telephone line & \\
\hline & & $\begin{array}{l}\text { Impact Evaluation; } \\
\text { CR } 114 \text { at J ackson } \\
\text { Creek }\end{array}$ & $\begin{array}{l}2 \text { fill sections } 1.5 \mathrm{~m} \\
\text { thick }\end{array}$ & 2 ditches $0.5 \mathrm{~m}$ deep & 1 gully 1-3 m deep & & \\
\hline
\end{tabular}


Table 2, continued

\begin{tabular}{|c|c|c|c|c|c|c|c|}
\hline $\begin{array}{l}\text { Work } \\
\text { Order }\end{array}$ & County & Project & Fill Sections & Ditches & Gullies & $\begin{array}{l}\text { Underground } \\
\text { Utilities }\end{array}$ & Other \\
\hline & McLennan & $\begin{array}{l}\text { Impact Evaluation; } \\
\text { CR } 346 \text { at Live Oak } \\
\text { Creek }\end{array}$ & 2 fill sections $2 \mathrm{~m}$ thick & 4 ditches $<1$ m deep & 2 gullies 1 m deep & & \\
\hline & & $\begin{array}{l}\text { Impact Evaluation; } \\
\text { CR } 440 \text { at Patten } \\
\text { Branch }\end{array}$ & 2 fill sections $2 \mathrm{~m}$ thick & 4 ditches $0.5 \mathrm{~m}$ deep & 2 gullies $0.5 \mathrm{~m}$ deep & & $\begin{array}{l}\text { lake construction } \\
\text { and contouring of } \\
\text { adjacent land }\end{array}$ \\
\hline & & $\begin{array}{l}\text { Impact Evaluation; } \\
\text { CR } 774 \text { at Castleman } \\
\text { Creek }\end{array}$ & 2 fill sections $2 \mathrm{~m}$ thick & 1 ditch 1 m deep & 1 gully 4 m deep & $\begin{array}{l}1 \text { fiber optic line } \\
2 \text { irrigation pipes }\end{array}$ & $\begin{array}{l}\text { plowing of } \\
\text { adjacent fields }\end{array}$ \\
\hline & & $\begin{array}{l}\text { Impact Evaluation; } \\
\text { CR } 581 \text { at Tehuacana } \\
\text { Creek }\end{array}$ & 2 fill sections $1 \mathrm{~m}$ thick & 4 ditches $0.5 \mathrm{~m}$ deep & 1 gully $1 \mathrm{~m}$ deep & & \\
\hline \multirow[t]{2}{*}{40} & Panola & $\begin{array}{l}\text { Survey; FM } 10 \text { at } \\
\text { Murvaul Creek }\end{array}$ & $\begin{array}{l}5 \text { fill sections } 2.5 \mathrm{~m} \\
\text { thick }\end{array}$ & $\begin{array}{l}10 \text { ditches } 1.0-1.5 \mathrm{~m} \\
\text { deep }\end{array}$ & & telephone lines & 3 gas pipelines \\
\hline & Titus & $\begin{array}{l}\text { Survey; FM } 127 \text { at } \\
\text { Tankersley Creek }\end{array}$ & 2 fill sections $1 \mathrm{~m}$ thick & $\begin{array}{l}4 \text { ditches } 1.0-1.5 \mathrm{~m} \\
\text { deep }\end{array}$ & 2 gullies 2 m deep & 1 telephone line & $\begin{array}{l}\text { water treatment } \\
\text { plant effluent } \\
\text { pipeline }\end{array}$ \\
\hline \multirow[t]{5}{*}{41} & Dallas & $\begin{array}{l}\text { Impact Evaluation; } \\
\text { Rylie Crest Dr. at } \\
\text { Hickory Creek }\end{array}$ & $\begin{array}{l}2 \text { fill sections } 2.5 \mathrm{~m} \\
\text { thick }\end{array}$ & 2 ditches $0.5 \mathrm{~m}$ deep & & 1 sewer line & \\
\hline & Denton & $\begin{array}{l}\text { Impact Evaluation; } \\
\text { Country Club Rd. at } \\
\text { Graveyard Branch } \\
\text { tributary }\end{array}$ & $\begin{array}{l}2 \text { fill sections } 1-2 \mathrm{~m} \\
\text { thick }\end{array}$ & $\begin{array}{l}2 \text { ditches } 0.5-1.0 \mathrm{~m} \\
\text { deep }\end{array}$ & 1 gully 1 m deep & 2 telephone lines & $\begin{array}{l}\text { adjacent roadside } \\
\text { park }\end{array}$ \\
\hline & Ellis & $\begin{array}{l}\text { Impact Evaluation; } \\
\text { Ebenezer Rd. at Grove } \\
\text { Creek }\end{array}$ & & & 1 gully $0.5 \mathrm{~m}$ deep & & \\
\hline & & $\begin{array}{l}\text { Impact Evaluation; } \\
\text { West Main St. at Red } \\
\text { Oak Creek }\end{array}$ & $\begin{array}{l}2 \text { fill sections } 1.5 \mathrm{~m} \\
\text { thick }\end{array}$ & 2 ditches $0.5 \mathrm{~m}$ deep & $\begin{array}{l}2 \text { gullies } 0.5-1.5 \mathrm{~m} \\
\text { deep }\end{array}$ & $\begin{array}{l}2 \text { telephone lines } \\
1 \text { gas pipeline }\end{array}$ & \\
\hline & Kaufman & $\begin{array}{l}\text { Impact Evaluation; } \\
\text { CR } 313 \text { at Muddy } \\
\text { Cedar Creek tributary }\end{array}$ & & 1 ditch $0.5 \mathrm{~m}$ deep & 4 gullies $1 \mathrm{~m}$ deep & 1 telephone line & road grading \\
\hline
\end{tabular}


construction of dirt, gravel, or paved driveways, often with associated culverts, to access fields, businesses, and residences beyond existing rights of way; plowing of fields adjacent to existing rights of way; construction and maintenance of railroad beds near existing rights of way; excavation of stock tanks on adjoining lands; landscaping adjacent to existing rights of way; and adjacent commercial development. Occurring more commonly but with low impacts were overhead transmission and telephone lines, which were observed along the edges of the rights of way at many locations.

By combining information on the observed/ presumed depth of these disturbance factors, their horizontal extent, the size of the existing right of way, and planned new right of way or construction easements, it was possible to identify areas where disturbance has been so severe that archeological remains (if present) would be unlikely to survive with good integrity-i.e., areas where survey was not warranted. Areas lacking such disturbance typically were recommended for survey, especially if the potential for sites was considered high (i.e., on terraces or upland margins overlooking medium-sized and larger water courses) or if thick alluvial deposits that could host archeological remains in stratified contexts were present.

To illustrate how this worked in practice, four idealized scenarios based on actual Impact Evaluations are described. In Scenario 1, the Transportation Activity will involve replacement of a bridge across a small creek on a county road with a narrow (ca. $12 \mathrm{~m}$ ) right of way. The new bridge will be slightly longer and wider than the old bridge, but it will be in the same location. The approaches will be reconstructed for ca. $30 \mathrm{~m}$ from both ends of the bridge. Because the bridge will be in the same position and the approaches will not be realigned, no new right of way is required. The bridge will be closed during construction and local traffic rerouted to a nearby county road, and thus no easement for a temporary detour outside the right of way is needed. In this case, the primary existing disturbance factors consist of the following: fill sections $0.5-1.0 \mathrm{~m}$ thick are present on both sides of the bridge, extending the full length of the project area and covering all but ca. $2 \mathrm{~m}$ on each edge of the right of way; ditches $1 \mathrm{~m}$ wide and less than $0.5 \mathrm{~m}$ deep are present between the fill sections and right of way edges; on one side of the creek, the ditches on both sides of the fill section have eroded to a depth of $1 \mathrm{~m}$ for a distance of ca. $10 \mathrm{~m}$ back from the creek, with these erosional gullies widening to ca. $2 \mathrm{~m}$ at the creek banks; and a buried telephone line is present along one edge of the right of way for the full length of the project area. The cutbanks of the creek expose ca. $2 \mathrm{~m}$ of fine-grained Holocene alluvium (bedrock is not visible above the water level, and thus the full thickness of the Holocene deposits cannot be determined). No archeological materials are visible in the cutbanks, but they are covered by vegetation, and visibility is poor. Impact Evaluation for this project area would result in a recommendation that no survey be required. While the Holocene alluvium is sufficiently thick to contain buried archeological remains in good context, the existing zone of disturbance probably approximates what will be disturbed by removal of the old bridge, construction of the slightly larger new bridge, and reconstruction of the fill sections. Hence, if a buried site is present, the new construction will not impact it to any greater extent than it has been disturbed already. In this example, almost all of the existing right of way likely has been disturbed to a depth of 0.5 to $1.0 \mathrm{~m}$ below the original surface by placement of the original fill sections, ditch excavation, gully erosion, and placement of the buried telephone line. In addition, it is expected that areas immediately around the bridge (i.e., within 2-5 m) were disturbed to a greater depth (at least $2 \mathrm{~m}$ ) by construction of the original bridge.

The same parameters apply to Scenario 2, except that TXDOT will need to acquire a construction easement extending up to $12 \mathrm{~m}$ outside the existing right of way for a temporary detour to allow local traffic to continue to cross the creek during construction. Because the cutbanks show Holocene alluvium with sufficient thickness to contain buried archeological remains in good context and because the area of the construction easement shows only minor disturbance from cattle grazing, 
Impact Evaluation would result in a recommendation that this area outside the existing right of way be surveyed with backhoe trenches. The trenches would be excavated to a depth of at least $1.5 \mathrm{~m}$ (the assumed maximum depth of substantial disturbance), with the sediments removed and the trench walls examined for archeological remains. A maximum of four trenches probably would be dug, since the temporary detour will extend only ca. $30 \mathrm{~m}$ on either side of the creek. In a slight variation of this scenario, survey probably would not be called for if the creek cutbanks showed thin $(<1 \mathrm{~m})$ alluvium sitting on bedrock and the gullies showed the alluvium thinning away from the creek, since the potential for buried archeological deposits would be lowered.

In Scenario 3, TxDOT plans to turn a twolane highway across a major river valley into a four-lane divided highway, adding a new bridge across the river and several relief structures across sloughs. A similar project had been planned years ago, and new right of way had been acquired and surveyed archeologically (with shovel tests but no trenches) at that time. Large (up to $5 \mathrm{~m}$ high) fill sections adjoin the existing bridge and relief structures, occupying about 40 percent of the ca. 100-m-wide right of way. Ditches, gullies, access roads to fields and fishing areas, and buried utilities occupy another 10 percent. Because half of the large right of way remains undisturbed (except probably for minor surface disturbance associated with initial clearing after acquisition by TxDOT) and because the river valley contains many meters of Holocene fill, survey with trenching clearly is warranted. As above, the trenches would be excavated to at least $1.5 \mathrm{~m}$, with those close to the new bridge and relief structures taken deeper (ca. $3 \mathrm{~m}$ ) if the water table allows due to the likely deeper impacts that will result from putting in these large structures. The number of trenches would depend on a variety of factors, including the number and distribution of landforms evident on the surface, access off the existing high fill sections, and the extent of areas with ponded water. Of course, survey also would be recommended if TxDOT was acquiring new right of way (or construction easements) in this example. The same factors would affect how the trenching was done, with additional complications perhaps added by dense woods in the new right of way. Also, survey with shovel testing probably would be recommended if new right of way extended onto the upland margins adjacent to the valley.

Scenario 4 involves widening a bridge across a medium-sized stream and adding shoulders to the adjoining two-lane road for $0.8 \mathrm{~km}$ from valley wall to valley wall. Because only half of the bridge will be under construction at a time, a detour will not be needed. No new right of way will be required, as the existing one, at $29 \mathrm{~m}$ wide, is large enough to accommodate the new work. Fill sections 1-2 $\mathrm{m}$ high extend the full length of the project area and occupy 50-60 percent of the right of way. Shallow $(0.5 \mathrm{~m})$ ditches parallel the edges of the fill sections, and buried telephone/fiber optic lines are at both edges of the right way, leaving about $5 \mathrm{~m}$ of right of way with only limited surface disturbance on each side of the road. About $3 \mathrm{~m}$ of Holocene alluvium are visible in the creek cutbanks, with the creek having a bedrock bottom. While no archeological remains can be seen in the cutbanks, the potential for sites in good context appears high based on the thickness of the deposits. Despite this assessment of site potential, Impact Evaluation would result in a recommendation that no survey be required because the anticipated impacts are so minimal. Widening of the bridge will not affect any undisturbed areas, and widening of the roadway will result in the addition of new fill that will impinge on existing ditches and adjacent undisturbed right of way only to a limited extent.

\section{Sites Investigated}

Sixteen archeological sites and 1 possible site were investigated during 10 work orders. Descriptions of these sites, drawn from the original reports included on CD-ROM in Appendix B, are presented below. Table 3 summarizes the materials observed and recommendations made.

\section{Work Order 2, 41CV1620}

No cultural materials were observed in 
Table 3. Summary of archeological sites investigated

\begin{tabular}{|c|c|c|c|}
\hline $\begin{array}{l}\text { Work } \\
\text { Order }\end{array}$ & Site & Materials Observed & Recommendation \\
\hline 2 & $41 C V 1620$ & biface, debitage, historic structural remains & no further work \\
\hline 6 & 41UR28 & debitage, sherds, burned rocks & no further work \\
\hline \multirow[t]{3}{*}{9} & 41BL 1099 & $\begin{array}{l}\text { nineteenth-century house with associated } \\
\text { artifact scatter, twentieth-century dam }\end{array}$ & $\begin{array}{l}\text { outside project area; not } \\
\text { assessed }\end{array}$ \\
\hline & 41BL 1100 & burned rock feature, charcoal & $\begin{array}{l}\text { obtain radiocarbon date before } \\
\text { assessing further }\end{array}$ \\
\hline & 41BL 1101 & bifaces, debitage, cores & no further work \\
\hline \multirow[t]{2}{*}{13} & $41 \mathrm{HM} 44$ & $\begin{array}{l}\text { bifaces, debitage, modified flakes, cores, } \\
\text { burned rocks, mussel shells, snail shells }\end{array}$ & $\begin{array}{l}\text { no further work in ROW; part of } \\
\text { site outside ROW not assessed }\end{array}$ \\
\hline & $41 \mathrm{HM} 45$ & $\begin{array}{l}\text { possible hearth, core, burned rocks, mussel } \\
\text { shells, snail shells, bones, charcoal }\end{array}$ & test excavations \\
\hline 14 & 41UR36 & $\begin{array}{l}\text { burned rock feature, scraper, debitage, } \\
\text { pitted stone, burned rocks, burned nutshells, } \\
\text { mussel shell }\end{array}$ & test excavations \\
\hline 19 & 41RA86 & debitage, burned rock & no further work \\
\hline \multirow[t]{2}{*}{32} & $41 \mathrm{CS} 143$ & $\begin{array}{l}\text { Gary dart point, debitage, burned rocks, } \\
\text { burned nutshells }\end{array}$ & no further work \\
\hline & $41 C S 144$ & $\begin{array}{l}\text { debitage, burned rocks, burned nutshells, } \\
\text { whiteware, glass, metal }\end{array}$ & no further work \\
\hline 34 & - & animal bones, charcoal & $\begin{array}{l}\text { test excavations to determine if } \\
\text { archeol ogical materials are } \\
\text { present }\end{array}$ \\
\hline 35 & 41FA65 & none & no further work \\
\hline \multirow[t]{4}{*}{40} & 41PN 175 & $\begin{array}{l}\text { debitage, sherds, ochre, burned rock, burned } \\
\text { nutshells, charcoal, possible feature }\end{array}$ & test excavations \\
\hline & 41PN 176 & debitage, sherds, burned nutshell, charcoal & no further work \\
\hline & 41TT823 & debitage, sherd, burned rocks & no further work \\
\hline & 41TT824 & Yarbrough dart point, debitage, charcoal & no further work \\
\hline
\end{tabular}

the two Gradall trenches and in the cutbank exposures at CR 213 on Coryell Creek in Coryell County, but an extremely sparse scatter of flakes and one biface were observed on the $T_{1}$ surface east of the creek. This scatter covers an area ca. $30 \mathrm{~m}$ east-west by $18 \mathrm{~m}$ north-south and was designated 41CV1620. It is bordered by CR 213 and an erosional gully to the south and west, respectively. Also included within 41CV1620 are displaced structural remains present along the northern edge of the right of way. No historic artifacts or foundation remnants were found on the terrace surface or in Gradall Trench 1, located a few meters south of the location of the displaced remains. The origin and age of the structural remains are unknown, but the construction materials of unmodified limestone, cement, and concrete blocks are indicative of a twentieth-century age. A few flakes and unmodified chert nodules also were noted on the $T_{0}$ surface between $41 C V 1620$ and the 
creek. Since the uppermost deposits of this terrace are interpreted as being less than 100 years old, however, the debitage is not in primary context. Debitage and natural chert nodules and cobbles were observed in gravel bars located along the edges of the creek channel. These materials have been redeposited, most likely from upstream. Because of the sparseness of the remains at 41CV1620 and the apparent lack of subsurface deposits, the site is considered ineligible for listing in the National Register of Historic Places or designation as a State Archeological Landmark.

\section{Work Order 6, 41UR28}

Site 41UR28, recorded in 1980, was reported to occupy a low $(2-3 \mathrm{~m})$ rise $300 \mathrm{~m}$ northeast of the main channel of Little Cypress Creek in Upshur County. The rise was estimated to be $100 \mathrm{~m}$ in diameter and partially impacted by the southeastern right of way of State Highway 155. The site was defined based on quartzite and chert tertiary flakes, charcoal, burned hardwood nutshell fragments, mussel shell fragments, and bone fragments noted in rodent disturbances. The site type and cultural affiliation were not designated on the site form. However, Thurmond (1990:100) listed the site as limited in intensity of use for his inventory of recorded sites in the Cypress Creek basin. This classification was based on its extent and the density of surface artifacts.

Site 41UR28 was relocated during Work Order 6. It was found to be $100 \mathrm{~m}$ northeast of its plotted position and on both sides of the highway. The original plotting placed it on the southeast side of the highway between the northeastern relief structure (Relief Structure 2 ) and the main bridge. This area did not fit the topographic description of the site but, rather, was found to be low and wet. It was not logistically possible to get the Gradall into this area between the bridge and the relief structure. Consequently four shovel tests (Nos. 7-10) were excavated instead. These shovel tests encountered $30 \mathrm{~cm}$ of disturbed soils on top of gray sandy clay. No cultural materials were recovered from these tests. However, Gradall Trenches 4-7 placed on a series of three low rises on the southeast side of the highway just northeast of Relief Structure 2 did produce cultural materials. This series of rises, located approximately $100 \mathrm{~m}$ northeast of the original plotted position, better fits the original site description. Three of the trenches (Nos. 4, 5, and 6) encountered scattered burned rocks and lithic flakes within a deposit of yellowish brown sandy loam extending 15 to $70 \mathrm{~cm}$ below the surface. This deposit overlies a firm brown sandy clay with obvious polygonal cracks filled with a fine yellow sand. Artifacts appear to stop at the top of the sandy clay. The majority of the artifacts observed came from Trench 5, consisting mostly of burned rocks; only two quartzite flakes were recovered from the backdirt of the trench. Shovel Tests 1 and 2 also were placed in the area, but only Shovel Test 2, located between Trenches 4 and 5, produced an artifact-one burned rock from $40-50 \mathrm{~cm}$ below the surface.

On the northeast side of Relief Structure 2 , located on the northwest side of the highway, an additional three sandy rises are present; these rises most likely are a continuation of the same landform encountered on the southeast side of the highway. Three trenches (Nos. 1-3) encountered cultural materials within the same yellowish brown sandy loam as observed on the southeast side of the highway. The deposit on the northwest side is slightly deeper at 12 to $92 \mathrm{~cm}$ below the surface, and it produced ceramic sherds in the upper $50 \mathrm{~cm}$ with burned rocks and lithic flakes scattered throughout. The majority of the materials observed came from Trenches 1 and 2 . The deposit in Trench 3 was thinnest at 10-55 cm below the surface. Materials recovered from the walls and backdirt of the trenches include two chert flakes, one silicified wood flake, one quartzite flake, one incised grog-tempered body sherd, and one plain bone-tempered body sherd. Shovel Test 11 also was excavated on this side of the highway; it produced one quartzite flake and one shell-tempered plain body sherd at $50-60 \mathrm{~cm}$ bel ow the surface.

In all, six lithic flakes and three sherds were recovered from the three trenches and two shovel tests placed on the site. The sherds recovered do not contain any diagnostic characteristics that would enable a firm type 
assignment. However, the presence of ceramics confirms that at least a Late Prehistoric Caddoan component is present. Due to the lack of recovery of other diagnostic artifacts, it is unclear if other components are present. Given the lack of discernible stratigraphy within the artifact-bearing deposit, it is unlikely that components could be isolated. The meager artifact recovery does, however, appear to confirm the low use intensity postulated by Thurmond (1990:100) from surface artifacts. The presence of faunal and floral materials as noted on the original site form was not confirmed. Extensive trench exposures through the site show that midden deposits are not present. Some charcoal was noted in the trenches, but it appears to be modern and associated with recent vegetation burning. The burned rocks observed were scattered throughout the sandy loam deposits; no burned rock features were encountered.

Since the same landform and yellowish brown sandy deposit are present on both sides of State Highway 155, the boundaries of 41UR28 were expanded to encompass both sides of the right of way. The site likely extends beyond the right of way to the northeast and southwest as does the landform. However, within the right of way the site covers an area of approximately $7,800 \mathrm{~m}^{2}$. It is likely that the site has been impacted by the original construction of Relief Structure 2 and by the deposition of fill to construct the elevated roadway approach to the relief structure.

Survey results indicate that 41UR28 has little potential to contain stratigraphically discrete cultural deposits relating to Native American use of the area. No intact cultural features were found, and no midden deposits appear to be present. The lack of such features and/or middens suggests that its potential to yield important information is limited. Hence, 41UR28 is considered ineligible for listing in the National Register of Historic Places or designation as a State Archeological Landmark.

\section{Work Order 9, 41BL1099-41BL 1101}

Three sites were recorded during Work Order 9 on FM 439 in Bell County: historic site 41BL 1099 and prehistoric sites 41BL 1100 and 41BL 1101. Only 41BL 1100 and 41BL 1101 are within the proposed right of way. Site 41BL 1099, approximately $100 \mathrm{~m}$ outside the project area, represents a reported stagecoach stop and associated outlying features, including a dam (ca. 1940). Site 41BL 1099 was recorded in a limited fashion because of its obvious historic age and potential significance. It consists of a two-story, cut limestone house that appears to date to the mid-nineteenth century, although it also has modern additions; an associated artifact scatter that dates mostly to the very late nineteenth century and first half of the twentieth century; and a twentieth-century rock and concrete dam with associated ditch just east of North Nolan Creek.

Cultural materials were observed in only one of the five trenches (Backhoe Trench 1) excavated during this survey. Historic materials (pieces of finished mortar and one sherd of yellowware [ca. 1900-1930s]) were found in a buried A horizon between 67 and $120 \mathrm{~cm}$; these probably are associated with 41BL 1099 just to the south. At a depth of $153 \mathrm{~cm}$, a concentration of burned rocks was exposed in the wall of the trench. A short extension was excavated parallel to and adjoining Backhoe Trench 1, extending $1.5 \mathrm{~m}$ southeast from the central portion of the original trench, to expose the burned rock concentration. This probable burned rock feature (possibly a hearth) consists of 11 burned limestone rocks and scattered charcoal covering an area of $60 \times 50 \mathrm{~cm}$. No artifacts were observed in association. TxDOT personnel collected a charcoal sample from the burned rock concentration for radiocarbon dating. Because of the likelihood that this represents a Native American occupation, albeit an apparently ephemeral one, this feature was recorded as 41BL 1100.

Site 41BL 1101 was located during pedestrian survey of the proposed right of way on the upland slope in the northeastern part of the survey area. The site, which is comparable to the Lithic Resource Procurement Areas that are so common in some upland areas just to the west at Fort Hood, consists of numerous primary and secondary flakes as well as numerous cores and bifaces scattered over an area $475 \mathrm{~m}$ long by $130 \mathrm{~m}$ wide. In addition, there are several mounds, $20-30 \mathrm{~cm}$ high and 
1.5-2.0 $\mathrm{m}$ in diameter, composed of primary and secondary flakes and chunks of chert. These mounds contain very little matrix between the chert pieces and could represent accumulations of debris associated with quarrying and the initial stages of reduction. Alternatively, they could be nothing more than old push piles resulting from land clearing. No temporally diagnostic artifacts or burned rock features were observed at 41BL 1101 . No shovel testing was done because of the good surface visibility and the lack of Holocene sediment deposition.

Historic site 41BL 1099 is outside the proposed right of way and therefore will not be impacted by the project. Site $41 B L 1100$ is within the proposed right of way, and, although buried, it is likely that this burned rock concentration and any associated cultural deposits would be impacted by construction associated with the bridge and road relocation. This feature may represent an ephemeral occupation based on the fact that no Native American artifacts were observed in Backhoe Trench 1 or Backhoe Trench 2 just $15 \mathrm{~m}$ away. Because of this and the possibility that this component has been disturbed by historic activities (based on the presence of twentieth-century materials in the overlying buried A horizon), 41BL 1100 may have a limited potential for the kind of information that would make it eligible for listing in the National Register of Historic Places or for designation as a State Archeological Landmark. On the other hand, its position in what appears to be stratified alluvium suggests that it could be in good geologic context. Because a radiocarbon sample that could help interpret this feature was taken, it was recommended that assessment of this site be deferred until a radiocarbon date could be obtained. Site 41BL1101 is an upland lithic procurement site. Because of the lack of Holocene deposition and accretional cultural features such as burned rock mounds, it does not have the kinds of contexts that would allow discrete occupational events, components, or periods of use to be isolated. For this reason, it lacks the capacity to yield important information about Native American use of the region, and it is recommended that it be considered ineligible for listing in the National Register of Historic
Places or designation as a State Archeological Landmark.

\section{Work Order 13, 41HM44 and 41H M45}

In conducting the Impact Evaluation on CR 311 at Cowhouse Creek in Hamilton County, one heavily patinated late-stage to finished biface and one burned rock were observed in an eroded area near the creek. From the top of the cutbank, the ground surface gently rises to the south and crests at the top of a small hill that lies just outside the project area and is bisected by CR 311. Site $41 \mathrm{HM} 44$ is located on this hill and appears to be the source of the biface and burned rock seen in the creek bank. Site 41HM44 was recorded, although most of it is beyond the project limits.

Site $41 \mathrm{HM} 44$ is a prehistoric open campsite of unknown age lying on the north/ northwest slope of a hill composed of Paluxy Sand, overlain by $20-50 \mathrm{~cm}$ of clay loam that probably represents Walnut Clay sediments redeposited by slopewash. Numerous mussel shells, burned rocks, pieces of lithic debitage, edge-modified flakes, cores, bifaces, and Rabdotus snail shells were observed across the site and to a depth of $25 \mathrm{~cm}$ in the CR 311 road cut. These cultural materials occur in the clayey sediments above the Paluxy Sand. No diagnostic artifacts were observed and no cultural materials were collected. One shovel test was excavated east of the road between the site boundary and the southern end of the project area, and three medial flake fragments were recovered. Excavation was terminated when large rocks were encountered at $20 \mathrm{~cm}$ bel ow the surface. Based on the surface extent of the cultural materials, the site is approximately $50 \times 20 \mathrm{~m}$, with the long axis oriented northeast-southwest. The extent of surface and buried cultural materials observed, combined with the landform where the site is located, suggest that intact cultural deposits are eroding out of the hillside and washing downslope toward Cowhouse Creek. While cultural materials found within the right of way may be attributable to $41 \mathrm{HM} 44$, they have washed into the right of way and, thus, are not in their original archeological context. These remains are 
not eligible for National Register listing or State Archeological Landmark designation. Because most of the site is beyond the limits of the current project area, it was not assessed for National Register/State Archeological Landmark eligibility.

A second site in Hamilton County, 41HM45, was recorded during survey on CR 168 at the Leon River during Work Order 13. The site was identified in a backhoe trench on a terrace ca. $40 \mathrm{~m}$ south of the river. The trench was excavated to a maximum depth of $1.95 \mathrm{~m}$. Dark brown clay loam occurred at $0-0.20 \mathrm{~m}$, and from 0.20 to $0.50 \mathrm{~m}$ was unconsolidated mottled light brown sand. At 0.50-0.95 $\mathrm{m}$ was a dark brown clay loam paleosol, within which burned rocks, mussel shells, and Rabdotus snail shells occurred between 0.65 and $0.70 \mathrm{~m}$. The deepest zone, 0.95-1.95 m, consisted of brown silty clay loam with calcium carbonate; burned rocks and mussel shells were noted at $1.00 \mathrm{~m}$ and again at the bottom of the trench at $1.95 \mathrm{~m}$. There also was an ovate area $(25 \times 20 \mathrm{~cm})$ in the bottom of the trench along the south wall consisting of patchy burned earth and charcoal, a sample of which was collected for possible dating. Root casts and charcoal flecks also were observed in the bottom of the trench. Cultural materials were encountered at $0.40 \mathrm{~m}$ in the east end of the trench and interpreted as being associated with the buried paleosol. The top of the paleosol was observed at $0.40 \mathrm{~m}$ in the east end of the trench, at $0.50 \mathrm{~m}$ in the center, and at $0.80 \mathrm{~m}$ at the west end suggesting a sloping surface. A swale that appears to be an abandoned channel of the river lies west of the trench. The sloping surface of the paleosol suggests that it may have been truncated by this old channel or that the soil developed after the channel had partially filled. Cultural materials were observed horizontally throughout the paleosol in the trench.

The materials observed consisted mostly of numerous mussel shells and burned rocks. The mussel shells varied from 5 to $10 \mathrm{~cm}$ in length, and the burned rocks varied from small angular and subangular fragments less than $5 \mathrm{~cm}$ in diameter to medium-sized angular and subangular rocks $10-15 \mathrm{~cm}$ in diameter. One core was observed, but no tools, projectile points, or lithic debris were found. In the east end of the trench, numerous pieces of unidentified bone were observed. They were in such poor condition that they crumbled when handled, and some pieces appeared to have been burned. Based on the evidence from the trench, $41 \mathrm{HM} 45$ appears to be a stratified campsite with considerable potential for containing intact features and preserved botanical and faunal remains. The ages of the cultural deposits are unknown, but it is possible that the buried paleosol at this locality equates to the Leon River and Tank Trail paleosols observed along the Leon River and Henson Creek (respectively) on Fort Hood (Mehalchick et al. 1999). These represent cumulic soils that frequently contain stratified cultural occupations dating to the latter half of the late Archaic period and the early part of the Late Prehistoric period. The size of the site is unknown, but it could extend along the river for some distance. Burned rocks and mussel shells noted eroding out of the south bank of the river approximately $0.75-1.00 \mathrm{~m}$ bel ow the surface ca. $100 \mathrm{~m}$ downstream from the proposed bridge location may be associated with 41HM45. Based on the likelihood that it contains important archeological data, 41HM45 is considered potentially eligible for listing in the National Register of Historic Places and designation as a State Archeol ogical Landmark, pending test excavations to more fully assess its significance.

\section{Work Order 14, 41UR36}

Site $41 U$ R36 was recorded during the Big Sandy Reservoir survey project conducted by Prewitt and Associates in 1985 (Perttula et al. 1986). Investigations at that time included surface collection, along with excavation of three shovel tests and one 1x1-m test unit. These investigations identified Archaic and Late Caddoan occupations. The site was found to cover an area of $7,500 \mathrm{~m}^{2}$ on both sides of FM 1002 at Glade Creek in Upshur County, with $450 \mathrm{~m}^{2}$ of the site estimated as having been destroyed by road construction (Perttula et al. 1986:277). Seventy-eight sherds, 60 pieces of debitage, and a Bell dart point were recovered.

Most of the sherds came from a $1,100-\mathrm{m}^{2}$ 
concentration at 0 to $20 \mathrm{~cm}$ below the surface east of the road. This concentration was defined mainly by surface indications, since the area was a garden providing good surface exposure. However, the vertical extent was determined by the placement of a 1x1-m test unit within the concentration. The ceramic sample collected from the concentration includes brushed, punctated, and incised Late Caddoan utility wares. This sample was considered contemporaneous with the Whelan phase of the Cypress Creek basin and the occupation at McKenzie Mound within the Big Sandy Creek basin (Perttula et al. 1986:278). A thermoluminescence date of A.D. 1450 was obtained on a carinated bowl sherd from this concentration (Perttula et al. 1986:278).

A Bell dart point was recovered $30-40 \mathrm{~cm}$ below the surface in the $1 \times 1-m$ test pit, while most of the lithic debitage was recovered at 30-80 cm (Perttula et al. 1986:277, 460). Based on this recovery, the investigators concluded that the site was potentially stratified with Caddoan materials confined to the upper $30 \mathrm{~cm}$ and Archaic materials below. Since the depth of excavation did not exceed $80 \mathrm{~cm}$ during these investigations, it was recognized that earlier materials also could be present. These characteristics led the investigators to conclude that the site has a high research potential; they recommended that it be considered potentially eligible for National Register listing (Perttula et al. 1986:211, 218). A second investigation at 41UR36 consisted of a re-location survey in October 1998 by TXDOT archeologists. Five shovel tests were excavated in the vicinity of 41UR36. All but one test were negative, with the positive test producing a single flake at $60 \mathrm{~cm}$ below the surface.

Site 4IUR36 was reinvestigated during Work Order 14. As the main portion of the site had been recorded south of the creek and east of the road, six backhoe trenches were placed along the southeastern proposed right of way and construction easement. Shovel Tests 7-9 were placed along trench walls to achieve deep controlled excavations. Six additional tests (Shovel Tests 6 and 10-14) were placed on both the southeast and southwest sides of the road within the proposed right of way or construction easement. These tests were placed in areas were backhoe access was problematic.

Site 41UR36 is located $60-90 \mathrm{~m}$ south of the channel of Glade Creek. As noted by the original recorders, the site is bisected by FM 1002 with the major portion of the site east of the road. The relatively undisturbed portion of the site within the proposed right of way and construction easement covers ca. $1,400 \mathrm{~m}^{2}$ east of the road, while ca. $350 \mathrm{~m}^{2}$ of the site are within the proposed right of way west of the road. These areas take into account the disturbance caused by the steep road cut which extends from the road edge to the edge of the existing right of way on both sides of FM 1002. Shovel testing and trenching indicate that the site extends to a depth of $140 \mathrm{~cm}$ on the east side of the road and ca. $100 \mathrm{~cm}$ on the west.

The site appears to be restricted to brown to yellowish brown Bowie sandy loam soils, which form an upland bench overlooking Glade Creek. Artifacts were found in these deposits in Trenches 2, 3, and 5 and Shovel Tests 7-13. Trenches 1 and 4 on the east side of FM 1002 and Shovel Tests 6 and 14 on the west side were placed on the slope below the bench. These trenches and shovel tests encountered a different soil consisting of brown to yellowish red sandy loam with abundant ironstone gravels, some of which were more than $5 \mathrm{~cm}$ in diameter. No artifacts were found in these trenches or shovel tests. Trench 6, placed at the edge of a shallow swale that marks the southern edge of the bench, encountered yellowish red sandy clay at $40 \mathrm{~cm}$ below the surface. No artifacts were recovered from Trench 6 or Shovel Test 9 excavated into its north wall. Given the height of these deposits above the creek (ca. $6 \mathrm{~m}$ ), it appears that colluvial processes were the main contributing factor to the deposition of the sediments.

Artifacts noted were lithic debitage, burned ironstone rocks, a nutting stone, a side/end scraper fashioned from a flake of chert, burned nutshells, and a mussel shell fragment. Based on the combined recovery from the six positive shovel tests, most of the materials appear to be at 40 to $110 \mathrm{~cm}$ below the surface. Given the depth of this concentration of materials and the lack of ceramics from any of the trenches or shovel tests, it is likely that the cultural deposits in this part of 
$41 U R 36$ are associated with the Archaic component identified during the original site survey. These artifacts also are associated with a small cluster of burned rocks (ca. $25 \mathrm{~cm}$ long) noted at $83 \mathrm{~cm}$ below the surface on the north wall of Trench 3 and a side/end scraper recovered from the backdirt of Trench 5 at 50 to $100 \mathrm{~cm}$ below the surface. The distributional evidence, the nature of the sediments, and the topographic setting suggest that this part of 41UR36 contains a zone of occupation representing one or more Archaic components encased in colluvial sediments derived from the uplands to the south. Bioturbation surely has moved artifacts around to some extent, but the presence of a possible burned rock feature and the fact that most of the materials are restricted to a 70-cm-thick zone suggest that cultural deposits with reasonable integrity are present. F urther, the lack of evidence for a Caddoan component in this part of the site suggests that the Archaic deposits may be relatively uncontaminated by later materials, a situation that is generally uncommon in northeastern Texas. Given the characteristics of the part of 41UR36 that is within the proposed right of way and construction easement, it appears that the site may be able to contribute to an understanding of prehistoric utilization of the Glade Creek drainage during the Archaic period. Thus, the site is considered to be potentially eligible for National Register listing and State Archeological Landmark designation, pending test excavations to more fully assess its significance.

\section{Work Order 19, 41RA86}

One archeological site, 41RA86, was discovered during the Impact Evaluation on State Highway 19 at the Sabine River in Rains County. The site was found on the uplands at the north end of the project area along the western edge of the present highway right of way. The site was discovered at the top of the road cut in a surface disturbance caused by the recent planting of grasses. Surface recovery from a 5x30-m area consisted of three quartzite flakes and a small fire-cracked rock. Three shovel tests were excavated in the vicinity of the surface scatter, with only Shovel Test 1 producing a single flake at 10-
$20 \mathrm{~cm}$ bel ow the surface. Sediments on top of the road cut are shallow, $25 \mathrm{~cm}$ or less, above red clay. The site most likely extends west beyond the right of way. Given its shallow nature and the fact that it has been disturbed by an underground telephone cable and grass planting operations (as well as by the road cut itself), the part of the site within and immediately adjacent to the right of way does not appear eligible for National Register listing or State Archeological Landmark designation.

\section{Work Order 32, 41 CS143 and 41 CS144}

Previously recorded sites $41 \mathrm{CS} 143$ and $41 C S 144$ were investigated in surveys along FM 250 at Black Cypress and Kelly Creeks in Cass County. Site 41CS143, located within the proposed right of way ca. $225 \mathrm{~m}$ north of Black Cypress Creek, was recorded as a prehistoric campsite by TxDOT personnel in 1989 and 1994. Artifacts recovered in 1989 (surface survey) and 1994 (shovel testing and excavation of one Gradall trench) include nondiagnostic flaked lithic artifacts, an Archaic dart point, and a mano. As a result of these investigations, the vertical extent of the site was estimated to be $130 \mathrm{~cm}$ and further testing was recommended.

Site $41 C S 143$ is situated on the $T_{2}$ terrace ca. $225 \mathrm{~m}$ north of the Black Cypress Creek bridge. Seven backhoe trenches and four shovel tests were excavated on the $T_{1}$ and $T_{2}$ terraces in the vicinity to determine the horizontal and vertical extent of the site. Backhoe Trench 6 was on the $T_{1}$ tread 60 morth of the Black Cypress Creek slough and relief structure, and Backhoe Trench 1 spanned the $T_{1} / T_{2}$ riser $90 \mathrm{~m}$ north of the slough. Backhoe Trenches 1 and 6 sampled the upper $150 \mathrm{~cm}$ of the $T_{1}$ landform, which consists of a $10-\mathrm{cm}$ thick brown loamy fine sand $A$ horizon and a mottled 30-40-cm-thick BC and Cc horizon formed in light yellowish-brown fine sand. Backhoe Trenches 2-5 and 7 were located on 41CS143. Backhoe Trenches 3 and 5 were profiled and characterize the $T_{2}$ landform as having a 7-42-cm-thick dark yellowish brown loamy fine sand AC horizon overlying a 43-cmthick dark yellowish brown Bw horizon formed in pale brown to yellow sand. 
Shovel Test 1 was excavated on the east wall of Backhoe Trench 2 to a depth of $180 \mathrm{~cm}$. A burned nutshell fragment was recovered at 40-50 cm, and a lithic flake was encountered at $80-90 \mathrm{~cm}$. Shovel Test 2 was dug on the east wall of Backhoe Trench 3 to a depth of $160 \mathrm{~cm}$. Cultural materials recovered between 40 and $70 \mathrm{~cm}$ consist of a burned nutshell fragment, two lithic flakes, and a burned rock. Shovel Test 3 was excavated on the east wall of Backhoe Trench 4 to a depth of $150 \mathrm{~cm}$. A Gary dart point was recovered at $70-80 \mathrm{~cm}$. Shovel Test 4 was dug on the east wall of Backhoe Trench 5 to a depth of $150 \mathrm{~cm}$. No cultural materials were recovered from this test. No features or midden staining were observed in any of the excavations. As evidenced by the recovery of only four lithic artifacts from three of four shovel tests, 41 CS143 contains a very low density scatter of artifacts that probably could not be isolated into discrete cultural components. Coupled with the lack of midden staining and apparent lack of features, this indicates that the site has a low potential to yield important information. As a result, this site is considered ineligible for listing in the National Register of Historic Places or designation as a State Archeological Landmark.

Site 41CS144 is located $100-160$ m north of Kelly Creek within the proposed right of way on the uplands and has both historic and prehistoric components. It was recorded originally by TxDOT personnel in 1989 and defined by the occurrence of surface lithic and historic artifacts. TxDOT personnel excavated 25 shovel tests in 1994. Only 3 of these tests were positive. One test yielded one flake, one nail, and one sherd of clear glass at $20-30 \mathrm{~cm}$; a second test contained two flakes at 40$50 \mathrm{~cm}$; and the third test yiel ded one flake and one piece of glass at $20-30 \mathrm{~cm}$. Historic materials (i.e., ceramics, a brick fragment, part of an iron skillet, and a clear glass bottle) were observed on the surface, with a concentration just outside the proposed right of way apparently representing an early-twentieth-century tenant house that had been torn down in the 1960s.

When revisited during Work Order 32, visibility on $41 \mathrm{CS} 144$ was good due to recent agricultural disturbance, and a piece of white- ware and one lithic flake were observed on the surface. Backhoe Trenches 1-7 were dug on the colluvial uplands in the immediate vicinity of 41CS144. Backhoe Trench 4 revealed a typical profile consisting of a 10-cm-thick pale brown loamy fine sand AC horizon over-lying a 60-cm-thick brown fine sandy loam Bw horizon, over a C horizon $56+\mathrm{cm}$ thick consisting of strong brown sand. Shovel Test 1 was dug on the south wall of Backhoe Trench 7 to a depth of $210 \mathrm{~cm}$. One piece of glass and one piece of metal were recovered from the upper $20 \mathrm{~cm}$, and possible burned rocks were recovered at $50-70 \mathrm{~cm}(n=5), 90$ $100 \mathrm{~cm}(\mathrm{n}=4)$, and $170-180 \mathrm{~cm}(\mathrm{n}=1)$. One lithic flake was recovered at $180-190 \mathrm{~cm}$. Shovel Test 2 was excavated on the south wall of Backhoe Trench 6. Two sherds of window glass and a metal eyelet were collected from the upper $20 \mathrm{~cm}$. Single pieces of lithic debitage were found at $40-50$ and $120-130 \mathrm{~cm}$. Four burned nutshell fragments and two possible burned rocks were found at $50-70 \mathrm{~cm}$, and a single possible burned rock was found at $170-180 \mathrm{~cm}$. No features or midden staining were observed in the trenches or shovel tests. Shovel Tests 3 and 4 were placed ca. $200 \mathrm{~m}$ north of 41CS144 and were dug to a maximum depth of $100 \mathrm{~cm}$. Neither test contained any cultural materials. These negative results, along with the recovery of materials from Shovel Tests 1 and 2 and the fact that artifacts were found in only 3 of the 25 tests dug by TxDOT personnel in 1994, indicate that $41 C S 144$ extends only ca. $60 \mathrm{~m}$ north-south.

Artifacts were found in low density dispersed throughout the upper ca. $190 \mathrm{~cm}$ of sediment at 41CS144 with the historic (twentieth century) materials confined to the upper $20 \mathrm{~cm}$. The low-density nature of the prehistoric deposit is evidenced by the fact that only 5 of the 27 shovel tests excavated in 1994 and 2000 contained cultural materials, with these 5 tests yielding just seven lithic artifacts. Given these low densities and the apparent lack of features or midden staining, isolating meaningful components would be problematical. Further, trucks and large machinery have heavily disturbed the surface. Therefore, this site is considered ineligible for listing in the National Register of Historic Places or designation as a State Archeological Landmark. 


\section{Work Order 34}

Survey on FM 545 at Pilot Grove Creek in Collin County identified a possible prehistoric site; lacking artifact recovery, however, a site trinomial was not assigned. Three Gradall trenches were excavated in the proposed new right of way south of the road between the main channel of the creek and a western tributary. Trench 1 was located ca. $10 \mathrm{~m}$ east of the western tributary and ca. $120 \mathrm{~m}$ west of the main creek channel; Trench 2 was ca. $55 \mathrm{~m}$ east of the western tributary and ca. $75 \mathrm{~m}$ west of the main channel; and Trench 3 was ca. $110 \mathrm{~m}$ east of the western tributary and ca. $20 \mathrm{~m}$ west of the main stem of Pilot Grove Creek. Trenches 1 and 3 were $5 \mathrm{~m}$ long, while Trench 2 was $10 \mathrm{~m}$ long. All three were $1.7 \mathrm{~m}$ wide and 1.6-1.8 $\mathrm{m}$ deep.

Trench 1 exhibited a 42-cm-thick dark gray clay loam AC horizon over a very dark gray clay B horizon at 42 to $98 \mathrm{~cm}$ and a dark gray to dark grayish brown clay loam BC horizon at 98 to $173+\mathrm{cm}$. No artifacts or features were located, however, chunks and flecks of charcoal were noted at $127 \mathrm{~cm}$. Trench 2 to the east exhibited a very similar profile, and at 135 to $160 \mathrm{~cm}$ scattered charcoal and a bone fragment, apparently representing part of the pelvis of a bovid or other large mammal, were encountered. The trench was lengthened to $10 \mathrm{~m}$ (leaving balks between trench segments) and carefully troweled to determine if artifacts were associated with the bones and charcoal. No artifacts or features were observed, but additional scattered charcoal and a second bone (scapula) were encountered. The bones were collected, as were charcoal samples for radiocarbon dating. Trench 3 farther to the east exposed sediments similar to those seen in Trenches 1 and 2 , but it contained no artifacts, charcoal, or faunal materials.

While the youthful appearance of the profiles in Trenches 1-3, the fresh appearance of the bones (cow?) recovered, and the apparent lack of associated artifacts suggested that the upper 1.5-2.0 m of alluvium along Pilot Grove Creek could be of historic age, a radiocarbon assay on charcoal collected from Trench 2 yielded a calibrated one-sigma range of A.D. $1480-1650$ (330 \pm 30 B.P., Beta Analytic
Sample No. 140857). Based on the possible prehistoric age of the charcoal and associated bones, it is recommended that the locality be subjected to test excavations to determine if archeological materials are present.

\section{Work Order 35, 41FA65}

Previously recorded site 41F A65 is located within the area subjected to Impact Evaluation during Work Order 35 on State Highway 6 in Falls County. This site is located on the Pleistocene terrace immediately south of the Big Creek valley. It was recorded in 1996 by Dr. Nancy Kenmotsu of TxDOT based on a report by an informant, who had observed a few lithic flakes within the highway right of way. Dr. Kenmotsu noted the presence of debitage and a chert scraper in thin, highly disturbed deposits on the terrace. She concluded that the part of the site in the right of way lacks the capacity to contribute important information due to disturbance, but that more-intact parts of 41FA65 could lie outside the right of way. The site was not located during Work Order 35 as a result of tall grass and the placement of gravels. Based on TXDOT's previous investigation, however, it is likely that the part within the right of way has been destroyed. Thus, it is considered ineligible for National Register listing or State Archeological Landmark designation.

\section{Work Order 40, 41PN 175-41PN176 and 41TT823-41TT 824}

Surveys on FM 10 in Panola County and FM 127 in Titus County identified four sites: 41PN 175, 41PN 176, 41TT823, and 41TT824. Site 41PN 175 is located south of Murvaul Creek on a northward projecting interfluve edge at an elevation of $240 \mathrm{ft}$. The site is in a dense second-growth hardwood forest with a thick understory and leaf litter. This vegetation caused surface visibility to be poor and made trenching impractical. Thus, the horizontal dimensions of the site, determined to be $30 \times 90 \mathrm{~m}$ within the proposed right of way, are based on shovel testing and landform characteristics. The site is bounded on the north by the edge of the landform as it slopes to meet the floodplain edge. To the west, the existing 
right of way for FM 10 bounds the site. The site likely continues east beyond the proposed right of way edge, and possibly beyond FM 10 to the west, as the landform continues in those directions. In all, nine positive shovel tests (Shovel Tests 8, 9, and 38-44) define the site within the proposed right of way. Soils at the site are mapped as Sacul fine sandy loam. Shovel testing indicates that the fine sandy surface layer is 50 to $100 \mathrm{~cm}$ thick above bright yellowish brown sandy clay. The deepest soils were encountered at the north edge of the landform in Shovel Tests 9 and 41.

A possible feature was encountered in Shovel Test 8. A patch of reddish orange sandy clay was encountered at $55-65 \mathrm{~cm}$ below the surface in the southeast corner of the shovel test. This patch, which had the appearance and consistency of fire-hardened sediment, continued into the walls of the shovel test. A small lump of burned sandy clay and one flake from the level above the possible feature were the only artifacts recovered from the test. No charcoal, ash, or fire-cracked rocks were associated with the small part of this possible feature exposed. However, Shovel Test 8 is positioned between Shovel Tests 38, 40 , and 41 , which had the highest artifact frequencies at the site $(5,4$, and 23 artifacts, respectively). This pattern of artifacts around a possible feature might indicate the presence of identifiable activity areas. Total artifact frequency for the site can be calculated as 1.6 artifacts per $20-\mathrm{cm}$ level. The total artifact counts by level were as follows: $0-20 \mathrm{~cm}, 1$ flake and 6 sherds; $20-40 \mathrm{~cm}, 9$ flakes and 10 sherds; 40-60 cm, 1 flake and 6 sherds; 60 $80 \mathrm{~cm}, 4$ sherds; and $80-100 \mathrm{~cm}, 2$ sherds.

Recovery from the shovel tests consisted of 11 lithic flakes, 2 fragments of petrified wood, 1 fragment of red ochre, 28 ceramic sherds, 1 piece of burned sandy clay, 1 fragment of burned sandstone, 4 burned nutshell fragments, and 1 piece of charcoal. The flakes are comprised mainly of quartzite and represent secondary and tertiary reduction. The petrified wood fragments are small $(<3 \mathrm{~cm})$ and may represent shatter from working this kind of stone, which does not readily fracture conchoidally.

The ceramic sherds also are small, ranging in size from less than $1 \mathrm{~cm}$ to $3 \mathrm{~cm}$. Most of the sherds are bone tempered $(n=14)$, with bone/grog temper $(n=7)$ and grog temper $(n=7)$ evenly represented. Ten sherds are decorated with brushing $(n=5)$, incised lines $(n=2)$, appliqué $(n=2)$, or punctations $(n=1)$. Of the remaining sherds, 8 have no decoration and 10 are either eroded or too small to determine surface treatment. Only 1 rim sherd was recovered. It appears to be a fragment of a bottle neck with a rounded lip and an incised diagonal line bel ow the lip. The ceramic sample is indicative of a Caddoan occupation, although the size of the sherds and the size of the sample do not enable confident association with particular ceramic types or time periods. Still, the presence of brushed and appliqué decorated sherds points to a middle or late Caddoan period occupation when these decorative techniques became common on utility wares (Thurmond 1990: 227-229). Ceramic types associated with these time periods, such as Crockett Curvilinear Incised, Pennington Punctated-Incised, Poynor Engraved, Ripley Engraved, and Harleton Appliquéd, have been recovered from 41PN 13 and 41PN 15 located near 41PN 175.

The presence of ceramic utility ware, lithic debitage, and a possible burned clay feature suggests that 41PN175 represents a small Caddoan camp or farmstead. The harvesting of trees and road construction likely have disturbed the site to some extent, but the presence of the possible feature accompanied by a potentially unmixed Caddoan domestic artifact assemblage with possible intrasite artifact patterning suggests that the site may be able to provide important information on the nature of Caddoan settlement within the mid-Sabine River drainage. As such, 41PN175 may be eligible for listing in the National Register of Historic Places and designation as a State Archeological Landmark. It is recommended that archeological testing be undertaken before construction begins to clarify the site's potential to yield important information.

Site 41PN176 is located in pasture at the floodplain edge north of Murvaul Creek. The site is situated on a small rise at an elevation of $235 \mathrm{ft}$. Its dimensions were defined as $25 \times 60 \mathrm{~m}$ within the proposed right of way by the extent of the rise and positive Shovel 
Tests 27 and 48. Surrounding negative Shovel Tests $25,26,28,45$, and 47 indicate that the site does not extend beyond the proposed right of way, nor does it extend onto the upland edge to the north. Artifact recovery was low at 0.7 artifacts per $20-\mathrm{cm}$ level. The artifacts were recovered from 0 to $100 \mathrm{~cm}$ below the surface. Shovel Test 27 yielded one ceramic sherd from the upper $20 \mathrm{~cm}$ and one at 80$100 \mathrm{~cm}$. Shovel Test 48 yielded one sherd at 0$20 \mathrm{~cm}$, one flake and two sherds at $40-60 \mathrm{~cm}$, and one sherd at $60-80 \mathrm{~cm}$.

Recovery from the shovel tests consisted of one quartzite flake, six ceramic sherds, one piece of burned clay, five pieces of charcoal, and one burned nutshell. All of the sherds are grog tempered. Decoration on four consists of brushing, zoned punctations, incised lines, and zoned incised lines. Though the ceramics indicate a Caddoan occupation, none is large enough to be confidently ascribed to known ceramic types, and as such the period of occupation remains unknown.

Site 41PN176 likely represents a site remnant associated with a Caddoan occupation of the area. Given the low artifact recovery, the type of occupation cannot be characterized. The site likely has been disturbed and probably reduced in size by continuing pasture maintenance activities and erosion. The current landowner recently has removed the trees and contoured the hillside to improve the pasture just north of the site, and extensive erosion is obvious in that area. Charcoal recovered from the upper two levels of Shovel Tests 27 and 48 may be suspect given that land clearing for pasture often involves the burning of stumps and other debris. Soils at the site are mapped as Thenas fine sandy loam and were observed in the shovel tests as a dark brown sandy loam to $40 \mathrm{~cm}$ below the surface and yellow brown sandy loam to at least $100 \mathrm{~cm}$. The dark brown surface layer could reflect organic enrichment from the prehistoric occupation, but this seems unlikely given the very low artifact frequencies. Given its condition and the low artifact frequency, it is unlikely that 41PN176 has the capacity to yield important information about Native American use of the region. It appears not to be eligible for National Register listing or State Archeological Landmark designation, and no further work is recommended.

Site 41TT823 is located at an elevation of $328 \mathrm{ft}$ on a small knoll at the western edge of the Tankersley Creek floodplain. The knoll is ca. $50 \mathrm{~m}$ in diameter; it is cut on the northwest by FM 127 and on the southeast by an earthen tank. Pasture covers most of the knoll, with thick trees and shrubs adjacent to the existing FM 127 right of way. Soils in the knoll area are mapped as Woodtell fine sandy loam. These soils were observed in the shovel tests to be a yellowish brown sandy loam that extends to at least $110 \mathrm{~cm}$ below the surface on top of the knoll.

Recovery from positive Shovel Tests 5, 20, 21, and 22 consists of 18 flakes, 19 fragments of petrified wood, 2 possible fragments of firecracked rock, and 1 ceramic sherd. The lithic debitage is predominantly quartzite with only 2 chert flakes recovered. The petrified wood fragments are small $(<4 \mathrm{~cm})$ and may represent shatter from working this kind of stone, which does not always fracture conchoidally. However, no obvious flake attributes were noted on these fragments, and thus they were not considered debitage. The ceramic sherd is a plain rim with flattened lip and no visible temper. The size of the rim, i.e., $1 \mathrm{~cm}$, prevented determination of rim diameter and orientation.

The recovery of the rim sherd and most of the debitage from 0 to $60 \mathrm{~cm}$ bel ow the surface suggests a possible Late Prehistoric Caddoan occupation. Clearly, the presence of sites such as 41TT3, 41TT6, and 41TT108 nearby in the Tankersley Creek floodplain and on upland edges indicate a Caddoan presence in the area. In addition, the three flakes at $80-110 \mathrm{~cm}$ in Shovel Test 21 may indicate an earlier occupation. However, the overall low artifact frequency, which is 1 artifact per 20-cm level, would make definition of these components difficult. Because of the low artifact frequency and impacts from erosion and road construction, 41TT823 is not likely to have the kinds of information that would make it eligible for listing in the National Register of Historic Places or designation as a State Archeological Landmark. Therefore, it is recommended that no further archeological investigations be undertaken.

Site 41TT824 is located at an elevation of 
$340 \mathrm{ft}$ on the sideslope of a southwardtrending interfluve that forms the eastern edge of the Tankersley Creek floodplain. The interfluve supports pasture grasses with scattered trees and shrubs. Soils in the area are mapped as Woodtell fine sandy loam, and they were observed in the shovel tests to be yellowish brown sandy loam with a depth of at least $100 \mathrm{~cm}$ below the surface. Red sandy clay subsoil was encountered within 15 to $30 \mathrm{~cm}$ of the surface in shovel tests upslope and northeast of the site. The proximity of the subsoil to the surface in these tests and the deep soils on the sideslope suggest that erosion may be moving sediment and possibly artifacts downslope.

The site was defined by three positive tests (Shovel Tests 8, 9, and 10) and three negative shovel tests. The negative shovel tests were both upslope and downslope from the positive tests and encountered shallow surface soils, emphasizing the potential impacts of erosion on the site dimensions, which were determined to be $10 \mathrm{~m}$ northwestsoutheast and $30 \mathrm{~m}$ northeast-southwest within the temporary construction easement. It is probable that the site extends to the northwest beyond the construction easement edge. On the southeast, the road cut for FM 127 defines the site limits.

Artifacts were recovered from 20 to $80 \mathrm{~cm}$ bel ow the surface. Shovel Test 8 contained one Yarbrough dart point at $20-40 \mathrm{~cm}$; Shovel Test 9 contained three flakes at $20-60 \mathrm{~cm}$; and Shovel Test 10 contained 2 flakes at $60-80 \mathrm{~cm}$. Total recovery consists of one Yarbrough dart point, five quartzite flakes, one fragment of petrified wood, one siliceous pebble, and two pieces of charcoal. The dart point, made from red chalcedony, indicates that the site has an Archaic component. However, the very low overall artifact frequency of 0.4 artifacts per $20-\mathrm{cm}$ level makes further site definition problematic. Because of the low artifact frequency and impacts from erosion and road construction, 41TT823 is not likely to have the kinds of information that would make it eligible for listing in the National Register of Historic Places or designation as a State Archeological Landmark. Therefore, it is recommended that no further archeological investigations be undertaken.

\section{Patterns in Site Distributions}

With a sample of just 15 prehistoric sites and 1 possible site, it is difficult to draw conclusions about patterns in site distributions and associations between site locations and elements of the environment. Nonetheless, it is useful to note that sites were found in a variety of topographic settings near water courses, including upland margins, probable strath terraces between the floodplain and valley walls, floodplain rises (levees or upland remnants?), and floodplains proper. Most of the sites are in the Waco $(n=6)$ and Atlanta $(n=8)$ Districts, which is not surprising given the fact that most of the surveys were in these areas. One shallow upland site (41RA86) is in the Paris District, while the single possible site is buried in Holocene alluvium along Pilot Grove Creek in the Dallas District.

The Waco District sites include both upland (41BL1101, 41FA65, and 41HM44) and Holocene alluvial (41BL1100, 41CV1620, and $41 \mathrm{HM} 45$ ) settings, with the upland sites being restricted to the surface (or nearly so) and two of the alluvial sites having cultural deposits to depths of $1.5 \mathrm{~m}$ or more. In contrast, the three Atlanta District sites that are arguably within Holocene alluvium (41PN 176, 41TT823, and 41UR28) have deposits that are only about $1 \mathrm{~m}$ thick. Whether the low floodplain rises that these sites occupy are truly Holocene constructional features (e.g., levee remnants) or much older landforms (e.g., eroded terraces or upland outliers) remains to be determined, but in either case they lack thick Holocene deposits with the potential for deeply stratified sites. The five Atlanta District sites that are in upland or strath terrace settings (41CS143, 41CS144, 41PN 175, 41TT824, and 41UR36) have cultural deposits that are at least as thick as the floodplain rise sites, with $41 \mathrm{CS} 144$ yielding artifacts to almost $2 \mathrm{~m}$ below the surface. These sites appear to have variable potential for deeply stratified archeological remains, although the nature of sedimentation on such landforms underlain by sandy Eocene deposits remains a matter of debate (e.g., are the sands Holocene colluvium, Holocene eolian deposits, in situ weathered Eocene deposits, or a "reconstituted" stratigraphy formed by pedogenesis, 
graviturbation, gullying, and sheetwash [Fields 1990; Thoms 1993]?).

\section{Geomorphological Investigations}

Of the three work orders that included Survey with Geoarcheological Evaluations (Work Orders 2, 8, and 35), one produced substantive geomorphological information that warrants a summary here. Work Order 8 involved surveying $2.6 \mathrm{~km}$ on both sides of the Brazos River along Loop 340 on the southeast side of Waco in McLennan County. Twenty-six backhoe trenches were excavated and described, allowing for a reconstruction of the late Quaternary history of that part of the Brazos River valley based on stratigraphic relations, soil development, and correlation to other geol ogical studies. The original report on these investigations (included on CD-ROM in Appendix B) was produced without the benefit of assays on radiocarbon samples, which had been collected but not yet analyzed. This summary incorporates the eight radiocarbon dates obtained on soil humates after that report was completed (Table 4).

Three alluvial landforms were identified in the project area: Pleistocene terrace, Holocene flood terrace, and modern floodplain (Figure 5). Four radiocarbon ages were determined from samples in Backhoe Trench 25 of the flood terrace, three from samples in Backhoe Trench 2 of the flood terrace, and one from a sample in Backhoe Trench 9 of the floodplain.

Two broad alluvial stratigraphic units were identified beneath the flood terrace: a lower unit and an upper unit (see Figure 5). Based on radiocarbon ages from Backhoe Trenches 2 and 25, deposition of the lower unit was under way by $7210 \pm 40$ B.P. and had terminated no later than $4890 \pm 70$ B.P. A radiocarbon age of $5260 \pm 40$ B.P. was obtained from within a truncated pal eosol of the lower unit on the outer edge of the flood terrace in Backhoe Trench 2. It is possible that this soil is more developed (carbonate nodules) because it formed in a slowly aggrading flood basin setting. The equivalent paleosol from the lower unit exposed in Backhoe Trench 25 appears to have been proximal to the Brazos River channel during its formation based on the presence of channel sands. Thus, the area around Backhoe Trench 25 probably aggraded more rapidly, limiting long-term pedogenesis on a single stable surface.

Deposition of the upper unit beneath the flood terrace began between $4890 \pm 70$ and $2720 \pm 60$ B.P. and terminated no later than $1530 \pm 70$ B.P. In Backhoe Trench 25, the stacked paleosol sequence appears to again reflect rapid deposition as noted by beds at the base of each paleosol containing reddish brown clay clasts. Episodes of levee-type sedimentation in this position apparently prevented long-term pedogenesis on a single stable surface. In contrast, Backhoe Trench 2 revealed sediments from the upper unit without the

Table 4. Radiocarbon dates obtained from Brazos River alluvium in Work Order 8

\begin{tabular}{cccccc}
\hline Lab Number & $\begin{array}{c}\text { Backhoe } \\
\text { Trench }\end{array}$ & Landform & Depth $(\mathrm{cm})$ & ${ }^{14}$ C Age (B.P.) & $\delta^{13} \mathrm{C}$ \\
\hline Beta-129689 & 2 & flood terrace & $52-62$ & $1600 \pm 60$ & -15.1 \\
Beta-129688 & 2 & flood terrace & $76-86$ & $2000 \pm 60$ & -15.3 \\
Beta-129687 & 2 & flood terrace & $178-188$ & $5260 \pm 40$ & -13.8 \\
Beta-129686 & 9 & floodplain & $156-166$ & $1030 \pm 60$ & -19.2 \\
Beta-129683 & 25 & flood terrace & $40-50$ & $1530 \pm 70$ & -16.1 \\
Beta-129682 & 25 & flood terrace & $81-91$ & $2720 \pm 60$ & -17.0 \\
Beta-129684 & 25 & flood terrace & $97-107$ & $4890 \pm 70$ & -16.5 \\
Beta-129685 & 25 & flood terrace & $316-326$ & $7210 \pm 40$ & -15.2 \\
\hline
\end{tabular}




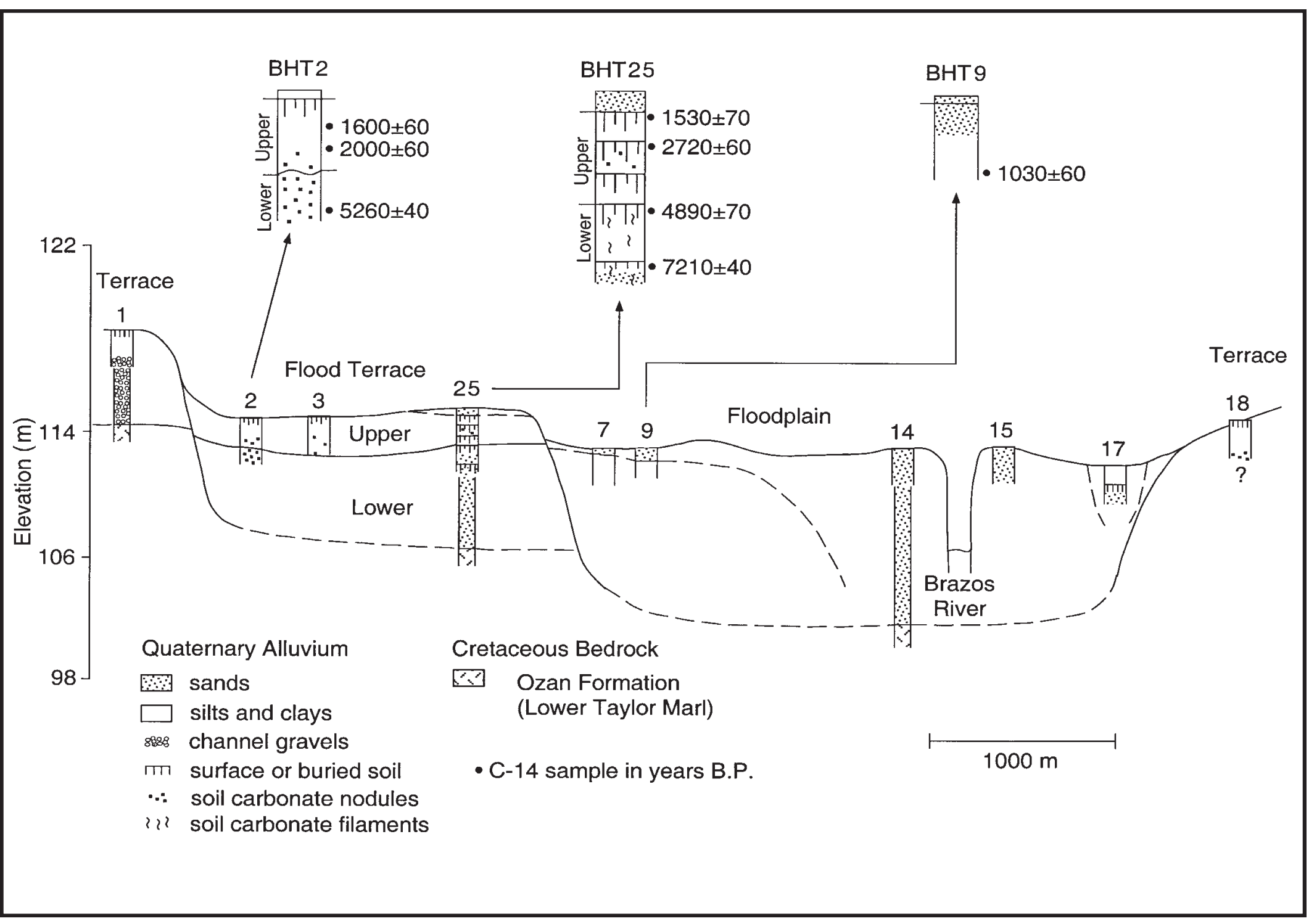

Figure 5. Alluvial stratigraphic cross section of the Brazos River valley along Loop 340 in MCLennan County. 
intervening flood deposits and stacked paleosols, thus producing one thick cumulic paleosol.

Radiocarbon ages from Backhoe Trenches 9 and 25 indicate that the Brazos River downcut shortly after $1530 \pm 70$ B.P. and that construction of the modern floodplain was under way no later than $1030 \pm 60$ B.P. Based on preserved sedimentary structures in the upper part of this unit, flood deposition has been ongoing until recently.

The results of the radiocarbon dating are consistent with the chronology from Brazos River sediments downstream near College Station, Texas, where Waters and Nordt (1995) dated a middle Holocene unit between 8500 and 4000 B.P. and a late Holocene unit between 4000 and 600 B.P. This correlates fairly well with the timing of deposition of the lower and upper units of the flood terrace in the Loop 340 project area.

The radiocarbon dating presented here generally supports the inferred chronology from the original investigation. Early Archaic sites could be preserved in primary contexts beginning at depths between 1.5 and $2.0 \mathrm{~m}$ beneath the flood terrace. Middle Archaic through Late Prehistoric features could be discovered in the upper unit beneath the flood terrace within the upper 1.5 to $2.0 \mathrm{~m}$. Cultural deposits within this stretch of the Brazos River valley have the potential to be somewhat more stratified in contexts such as that sampled by Backhoe Trench 25 because of rapid deposition interrupted by episodes of pedogenesis. Deposition was less rapid on the outer edge of the flood terrace in the vicinity of Backhoe Trench 2, providing fewer opportunities for well-defined stratification of archeological deposits. The floodplain could contain buried features dating to the Late Prehistoric period and later.

\section{Utility of Existing Methods}

In general, the methods employed for Impact Evaluations and Surveys appear to be consistent with a "reasonable and good faith effort" to comply with federal and state laws governing identification of archeological sites that are eligible for listing in the National Register of Historic Places or designation as
State Archeological Landmarks. The level of effort typically required to complete an I mpact Evaluation (1-2 hours for a single bridge replacement) seems appropriate given the intent of this type of work and the generally small sizes of the project areas. To the extent that Impact Evaluations can quickly separate those project areas where survey is truly a good idea from those where sites are very unlikely or almost surely disturbed, they are an efficient and relatively inexpensive measure to guard against the loss of important archeological data. As discussed below, however, the results of this project suggest that more-restrictive requirements could be placed on identifying when Impact Evaluations need to be done.

The levels of effort spent on Surveys and the amounts of work done (i.e., numbers of trenches and shovel tests) also seem appropriate given the sizes of the project areas, although the amount of work can vary based on a variety of factors other than project size (e.g., backhoe accessibility, depth to ground water, extent of ponded water, landowner permission to trench, extent of disturbance, and number and location of buried utilities that must be avoided during trenching). The work done on these surveys easily meets or exceeds the Texas Historical Commission's archeological survey standards, except in some cases where only trenches were dug. This occurred in some floodplain settings where shovel testing was considered ineffective and inefficient because of the thickness of the alluvium or because of dense clay soils. In these cases, the lack of shovel testing is compensated for by the much greater subsurface visibility afforded by the backhoe trenches and the fact that the number of trenches well exceeds the minimum required.

Beyond the question of whether the level of trenching or shovel testing is adequate, two issues concerning the effectiveness of the survey methods merit discussion here. The first pertains to the use of shovel tests in lieu of trenches. In most cases, shovel tests were dug in situations where there is no argument about their appropriateness, i.e., on landforms with thin Holocene deposits, on sites where the cultural deposits occur at shallow depths, and adjacent to backhoe trenches that 
extended to greater depths than can be reached normally with shovel tests. In a few surveys, however, shovel tests were excavated where trenches would have been preferable due to the thickness of the deposits. Trenching could not be performed because of dense woods and other access-limiting factors, or because of a lack of landowner permission, however. While shovel testing in these situations may not have the optimal approach in an ideal world, it does represent the required "good faith effort," considering the limitations.

The second issue pertains to the effectiveness of trenching in locating sites that lack conspicuous remains, such as rock features. While it is certain that trenches are more effective at identifying sites with numerous features or dense artifact concentrations than sites with low densities of cultural remains, it is noted that individual artifacts, burned rocks, and bones, as well as scatters of charcoal, were observed in some trenches during surveys performed under this contract. Several of these were tested subsequently by TxDOT personnel, with the results of testing confirming the survey-level observations that these are low-density cultural deposits (Lain Ellis, personal communication 2000). Further, TXDOT concluded that the cultural materials are so sparse at these locations that analysis would not yield meaningful interpretations, and the Texas Historical Commission concurred with this conclusion. Thus, there is good reason to believe that trenching, even without accompanying manual excavations, is an effective tool for determining the presence/absence of sites that might contain sufficiently important information to warrant designation as State Archeol ogical Landmarks.

\section{Recommendations}

Seven main recommendations resulting from this project are highlighted here. Some relate to issues that may be specific to how this project unfolded, while others have broader relevance and may have a bearing on how similar projects are conceptualized and handled in the future. In some cases, solutions to problems can be identified, and specific recommendations can be made. In others, solutions may be more nebulous or perhaps nonexistent.

1. Many of the Impact Evaluations were done without specific construction plans in hand, or even information about whether new rights of way or construction easements will be needed. This made it impossible to identify specific areas that will be impacted, and hence to identify specific areas that should be surveyed. Most often, this resulted in a generalized recommendation that survey should be done only if impacts will occur outside the existing right of way or below a certain depth within the right of way. Whenever possible, Impact Evaluations should be done after construction plans have been developed so that areas needing survey (or not) can be identified specifically.

2. In a few cases, Surveys were done without Impact Evaluations having been done first. While this may be logical in situations where it is certain that survey is needed, it can lead to unforeseen difficulties. For example, without the on-the-ground knowledge gained from an Impact Evaluation, it may be impossible to determine if the area needing survey can be accessed with a backhoe. This could be solved by ensuring that TXDOT district personnel have examined the area and made this determination.

3. To a substantial extent, assessment of existing impacts and likely impacts from a planned Transportation Activity is a subjective exercise based on past experience with construction projects, casual observation of road/bridge projects observed during travel to and from Surveys and Impact Evaluations, and common sense. This applies particularly to estimating the amount of disturbance caused by the placement of fill sections of varying sizes (i.e., through heavy equipment churning the ground during construction, and subsequent compaction by the weight 
of the fill). It usually was assumed that placement of a fill section had disturbed at least the upper $0.5 \mathrm{~m}$, with large fill sections disturbing the ground to a depth of $1 \mathrm{~m}$ or more, but empirical evidence to back this up was not sought. If TXDOT has, or has access to, such data, a synopsis of the kinds and depths of disturbances associated with projects of various kinds would be helpful to those doing Surveys and Impact Evaluations.

4. During the course of this project, eight Staff Archeologists or Geoarcheologists were responsible for doing Surveys and I mpact Evaluations, depending on TxDOT's scheduling of work orders. The maximum number working at any one time was four, and at times no one was working on the project. While this variability in work load may be unavoidable, a more-even distribution of work orders would have two benefits: it would make it easier to guarantee TXDOT that reports would be submitted on schedule and would make it easier to ensure consistency between work orders in terms of how the work was done and reported.

5. Most of the Surveys and I mpact Evaluations focused on settings where prehistoric sites, particularly buried ones in good contexts for identifying discrete components, might be expected, i.e., Holocene alluvium. Some projects included adjacent upland margins, and a smaller number encompassed stretches of road traversing uplands between streams, but the slant of most of the work orders was toward examination of areas with some potential for prehistoric, rather than historic, sites. To a substantial extent, this is a function of the nature of the Transportation Activities, since bridge re placements, of necessity, are in alluvial settings where prehistoric sites are more likely than historic ones. Given this and the generally small size of most bridge replacement con- struction areas, the likelihood that important historic sites would be impacted seems minimal. However, this may not be the case for larger projects, such as where long stretches of highway are to be widened. One way to compensate partially for this, other than pedestrian survey of all project areas (which may not be feasible), is to include review of historic maps (e.g., late-nineteenth- and early-twentiethcentury USGS maps, and county highway maps dating to the early decades of the twentieth century) for areas that are not likely to be examined closely during Impact Evaluations (i.e., uplands between streams). While the locations of buildings shown on these maps may themselves be too recent to be of interest archeologically, they may highlight areas where sites relating to earlier occupations (and thus potentially of greater archeological significance) may be expected.

6. Based on the observations made during the Impact Evaluations reported here, it appears that TxDOT could adopt more-restrictive criteria for determining when Impact Evaluations should be done. Specifically, survey seldom was recommended in project areas where impacts will be restricted to an existing narrow right of way, such as those typically associated with county roads. As discussed in Scenario 1 under I mpacts and Site Potential, the zone of existing disturbance approximates what will be disturbed by the bridge replacement. Any sites present will be impacted only minimally, and any areas impacted will have been disturbed by earlier construction. It is recommended that Impact Evaluations be done for bridge replacements on county roads with narrow existing rights of way only when new right of way will be acquired or when a construction easement will be needed.

7. Most of the Impact Evaluations done during this project recommended survey 
for those Transportation Activities involving acquisition of new right of way or construction easements, unless these areas had been disturbed substantially (e.g., by flood scouring) or contained only thin alluvium with a limited potential for buried archeological remains in good context. A legitimate question in such cases, however, asks how much new right of way/construction easement is enough to warrant survey. If the construction easement extends $1 \mathrm{~m}$ outside the existing right of way, should survey be performed? Probably not, given the very limited chance that such a narrow strip of land will contain important archeological information. How about if the new right of way reaches $20 \mathrm{~m}$ beyond the edge of the existing right of way? Assuming that Holocene alluvium with the potential for buried sites is present, survey surely would be warranted, given the large size of the area to be impacted. Where between 1 and $20 \mathrm{~m}$ should the line be drawn? From a practical standpoint (e.g., the width of an area required for a backhoe to work in), it is recommended that strips of new right of way/construction easement should be surveyed only if they exceed $5 \mathrm{~m}$ in width. This would have the greatest effect on Transportation Activities with narrow existing rights of way, since these are the situations where the existing rights of way are most likely to be disturbed from edge to edge. Where existing rights of way are wide, there is a greater likelihood that some undisturbed areas will be pre-sent; hence, survey may be needed regardless of how far the new right of way or construction easement extends outside the existing right of way. Based on this recommendation, it may be possible to determine whether Impact Evaluations and Surveys are warranted based solely on the size of the right of way and the extent of new right of way/construction easement. 


\section{REFERENCES CITED}

Barber, Byron L.

1969 The Hackberry Site. The Record 25(3):1824.

Barnhart, Edwin, Boyd Dixon, Stephen Kotter, Michael Nash, Kathryn Reese-Taylor, Elizabeth Skokan, and Rick Taylor

1997 Data Recovery Excavations at Site 41TT372 in the Tankersley Creek Watershed, Monticello B-2 Surface Mine, Titus County, Texas. Document No. 940608. Espey, Huston and Associates, Inc., Austin.

Black, Stephen L., Linda W. Ellis, Darrell G. Creel, and Glenn T. Goode

1997 Hot Rock Cooking on the Greater Edwards Plateau: Four Burned Rock Midden Sites in West Central Texas, Volumes 1 and 2. Studies in Archeology 22. Texas Archeological Research Laboratory, The University of Texas at Austin. Archeology Studies Program, Report 2. Environmental Affairs Department, Texas Department of Transportation, Austin.

Brayshaw, Thomas C.

1970 Henrietta Focus of the Possum Kingdom Basin. Unpublished Master's thesis, Department of Anthropology, University of Texas at Arlington.

Brewington, Robbie L., J ohn E. Dockall, and Harry J. Shafer

1995 Archaeol ogy of 41MX5: A Late Prehistoric Caddoan Hamlet in Morris County, Texas. Reports of Investigations No. 1. Texas A\&M U niversity, College Station.

Brooks, Robert L.

1989 Village F arming Societies. In From Clovis to Comanchero: Archeol ogical Overview of the Southern Great Plains, by J ack L. Hofman, Robert L. Brooks, J oe S. Hays, Douglas W. Owsley, Richard L. J antz, Murray K. Marks, and Mary H. Manhein, pp. 71-90. Research Series No. 35. Arkansas Archeological Survey, Fayetteville.

Brown, David O. (compiler)

1987 Archeology at Aquilla Lake, 1978-1982 Investigations. 3 Vols. Research Report 81. Texas Archeological Survey, The
University of Texas at Austin.

Brown, K. L., and S. A. Lebo

1991 Archaeological Testing of the Lewisville Lake Shordine, Denton County, Texas. Institute of Applied Sciences, University of North Texas, Denton.

Brown, L. F., J r., J . L. Goodson, and P. Harwood

1972 Geologic Atlas of Texas, Abilene Sheet. Bureau of Economic Geology, The University of Texas at Austin.

Bruseth, J ames E., Larry D. Banks, William A. Martin, Daniel J . Prikryl, and Timothy K. Perttula

1992 The 1992 Field School: Soggy but Successful. Texas Archeology (Newsletter of the Texas Archeological Society) 36(3):1, 7-13.

Bruseth, J ames E., Nancy A. Kenmotsu, William A. Martin, Daniel J. Prikryl, Timothy K. Perttula, J.A.Jaquier, and Larry D. Banks

1991 Summary of the 1991 Field School in Red River County, Texas. Texas Archeology (Newsletter of the Texas Archeological Society) 35(3):1, 6-10.

Bruseth, J ames E., and William A. Martin (editors)

1987 The Bird Point Island and Adams Ranch Sites: Methodological and Theoretical Contributions to North Central Texas Archae ology. Richland Creek Technical Series, Vol. II. Archaeology Research Program, Institute for the Study of E arth and Man, Southern Methodist University, Dallas.

Bruseth, J ames E., and Timothy K. Perttula

1981 Prehistoric Settlement Patterns at Lake Fork Reservoir. Texas Antiquities Permit Series Report No. 2. Texas Antiquities Committee, Austin, and Southern Methodist University, Dallas.

Campbell, Thomas N.

1983 Espinosa, Olivares, and the Colorado River Indians, 1709. Sayersville Historical Association Bulletin 3:2-16.

Cliff, Maynard B.

1994 Cultural Resources Survey of a Portion of the White Oak Creek Mitigation Area 
(WOCMA), Bowie, Cass, and Morris Counties, Texas: 1990-1992. White Oak Creek Mitigation Area Archeological Technical Series, Report of Investigations No. 2. Geo-Marine, Inc., Plano, Texas.

Cliff, Maynard B., Melissa Green, Steven M. Hunt, David Shanabrook, and Duane E. Peter

1996 Excavations in Area C of the Unionville Site (41CS151), White Oak Creek Mitigation Area (WOCMA), Cass County, Texas. White Oak Creek Mitigation Area Archeological Technical Series, Report of Investigations No. 4. Geo-Marine, Inc., Plano, Texas.

Cliff, Maynard B., and Steven M. Hunt

1995 Cultural Resources Testing of Three Sites within the Moist Soils Management Area (MSMA) of the White Oak Creek Mitigation Area (WOCMA), Cass County, Texas: 1992. White Oak Creek Mitigation Area Archeological Technical Series, Report of Investigations No. 3. Geo-Marine, Inc., Plano, Texas.

Collins, Michael B.

1990 Observations on Clovis Lithic Technology. Current Research in the Pleistocene 7:7374.

1995 Forty Years of Archeology in Central Texas. Bulletin of the Texas Archeological Society 66:361-400.

Collins, Michael B., and Kenneth M. Brown 2000 The Gault Gisement: Some Preliminary Observations. Current Archeology in Texas 2(1):8-11.

Collins, Michael B., Glen L. Evans, Thomas N. Campbell, Melissa C. Winans, and Charles E. Mear

1989 Clovis Occupation at the Kincaid Rockshelter, Texas. Current Research in the Pleistocene 6:3-4.

Collins, Michael B., Thomas R. Hester, and Pamela J . Headrick

1992 Engraved Cobbles from the Gault Site, Central Texas. Current Research in the Pleistocene 9:3-4.

Crook, Wilson W., J r., and R. K. Harris

1952 Trinity Aspect of the Archaic Horizon: The Carrollton and Elam Foci. Bulletin of the Texas Archeological and Paleontological Society 23:7-38.
1954 Traits of the Trinity Aspect Archaic: Carrollton and Elam Foci. The Record 12(1):2-16.

1957 Hearths and Artifacts of Early Man Near Lewisville, Texas, and Associated Faunal Material. Bulletin of the Texas Archeological Society 28:7-97.

1958 A Pleistocene Campsite Near Lewisville, Texas. American Antiquity 23(3):233-246.

Davis, E. Mott

1970 Archaeological and Historical Assessment of the Red River Basin in Texas. In Archeological and Historical Assessment of the Red River Basin, edited by Hester A. Davis, pp. 27-65. Research Series No. 1. Arkansas Archeological Survey, Fayetteville.

Davis, W. A., and E. Mott Davis

1960 The J ake Martin Site: An Archaic Site in the Ferrel's Bridge Reservoir Area, Northeastern Texas. Archaeology Series No. 3. Department of Anthropology, The University of Texas at Austin.

Dawson, Gerald L., and Timothy L. Sullivan

1973 Excavations at Lake Lavon, 1969. Research Report No. 25. Archaeology Research Program, Southern Methodist University, Dallas.

Diamond, David D., David H. Riskind, and Steve L. Orzell

1987 A Framework for Plant Communities Classification and Conservation in Texas. Texas J ournal of Science 39(3):203-221.

Dickinson, S. D.

1941 Certain Vessels from the Clement's Place, an Historic Caddo site. Bulletin of the Texas Archeological and Paleontological Society 13:117-132.

Duffield, Lathel F.

1963 The Strawn Creek Site: A Mixed Archaic and Neo-American Site at Navarro Mills Reservoir, Navarro County, Texas. Report submitted to the National Park Service by the Texas Archeological Salvage Project, The University of Texas at Austin.

Duffield, Lathel F., and Edward B. J elks

1961 The Pearson Site: A Historic Indian Site at Iron Bridge Reservoir, Rains County, Texas. Archaeology Series No. 4. Depart- 
ment of Anthropology, The University of Texas at Austin.

Ensor, H. Blaine, J œ W. Saunders, and C. S. Mueller-Wille

1992 Prehistoric Synthesis. In An Archeol ogical Survey of the Proposed South Bend Reservoir Area: Young, Stephens, and Throckmorton Counties, Texas, edited by J œ W. Saunders, C. S. Mueller-Wille, and David L. Carlson, pp. 259-303. Archeological Surveys No. 6. Archeological Research Laboratory, Texas A\&M University, College Station.

Fenneman, Nevin M.

1931 Physiography of Western United States. McGraw-Hill Book Company, Inc., New York.

1938 Physiography of Eastern United States. McGraw-Hill Book Company, Inc., New York.

Ferring, C. Reid

1975 An Archaeological Survey of the Grape vine Dam Area, Tarrant County, Texas. Archaeology Research Program, Southern Methodist University, Dallas.

1987 Geoarchaeology of Site 41C0141: A Late Holocene Locality in the Upper Trinity Basin. In Test Excavations at 41CO141, Ray Roberts Reservoir, Cooke County, Texas, edited by Daniel J. Prikryl and Bonnie C. Yates, pp. 1-54. Contributions in Archaeology No. 4. Institute of Applied Sciences, North Texas State University, Denton.

1989 The Aubrey Clovis Site: A Paleoindian Locality in the Upper Trinity River Basin. Current Research in the Pleistocene 6:9-11.

Ferring, C. Reid, and Bonnie C. Yates

1997 Holocene Geoarchaeology and Prehistory of the Ray Roberts Lake Area. Institute of Applied Sciences, University of North Texas, Denton.

1998 Archaeological Investigations at Five Prehistoric Sites at Lewisville Lake, Denton County, Texas. Center for Environmental Archaeology, University of North Texas, Denton.

Fields, Ross C.

1995 The Archeology of the Post Oak Savannah of East Central Texas. Bulletin of the Texas Archeological Society 66:301-330.

Fields, Ross C. (editor)

1990 Excavations at the Charles Cox, Lambs Crek Knoll, and Buffalo Branch Sites, J ewett Mine Project, Leon and Freestone Counties, Texas. Reports of I nvestigations No. 70. Prewitt and Associates, Inc., Austin.

Fields, Ross C., Marie E. Blake, and Karl W. Kibler

1997 Synthesis of the Prehistoric and Historic Archeology of Cooper Lake, Delta and Hopkins Counties, Texas. Reports of Investigations No. 104. Prewitt and Associates, Inc., Austin.

Fields, Ross C., and L. Wayne Klement

1995 Excavations at the Cottonwood Springs Site, J ewett Mine Project, Leon County, Texas. Reports of Investigations No. 102. Prewitt and Associates, Inc., Austin.

Fields, Ross C., L. Wayne Klement, C. Britt Bousman, Steve A. Tomka, Eloise F. Gadus, and Margaret A. Howard

1991 Excavations at the Bottoms, Rena Branch, and Moccasin Springs Sites, J ewett Mine Project, Freestone and Leon Counties, Texas. Reports of Investigations No. 82. Prewitt and Associates, Inc., Austin.

Forrester, R. E.

1994 Two Henrietta Focus Sites on the Brazos River in North Central Texas. Bulletin of the Texas Archeological Society 62:249266.

Gadus, Eloise F., Ross C. Fields, C. Britt Bousman, Steve A. Tomka, and Margaret A. Howard

1992 Excavations at the Finley Fan Site (41HP159), Cooper Lake Project, Hopkins County, Texas. Reports of Investigations No. 78. Prewitt and Associates, Inc., Austin.

Gill-King, $\mathrm{H}$.

1987 The Human Osteology of 41CO141. In Test Excavations at 41CO141, Ray Roberts Reservoir, Cooke County, Texas, edited by Daniel J . Prikryl and Bonnie C. Yates, pp. 101-104. Contributions in Archaeology No. 4. Institute of Applied Sciences, North Texas State University, Denton.

Gilmore, Kathleen

1986 French-Indian Interaction at an Early Eighteenth Century Post: The Roseborough Lake Site, Bowie County, Texas. Contri- 
butions in Archaeology No. 3. Institute of Applied Sciences, North Texas State University, Denton.

\section{Goode, Glenn T.}

1991 Late Prehistoric Burned Rock Middens in Central Texas. In The Burned Rock Middens of Texas: An Archeological Symposium, edited by Thomas R. Hester, pp. 71-93. Studies in Archeology 13. Texas Archeological Research Laboratory, The University of Texas at Austin.

Goode, Glenn T., and Robert J . Mallouf

1991 The Evant Cores: Polyhedral Blade Cores from North-Central Texas. Current Research in the Pleistocene 8:67-70.

Gregory, Hiram F .

1973 Eighteenth Century Caddoan Archaeology: A Study in Models and Interpretation. Unpublished Ph.D. dissertation, Department of Anthropology, Southern Methodist University, Dallas.

Guy, J anice A.

1990 Previous Archeological Investigations. In The Archeology and Bioarcheology of the Gulf Coastal Plain, by Dee Ann Story, J anice A. Guy, Barbara A. Burnett, Martha Doty Freeman, J erome C. Rose, D. Gentry Steele, Ben W. Olive, and Karl J. Reinhard, pp. 27-130. 2 Vols. Research Series No. 38. Arkansas Archeological Survey, Fayetteville.

Harris, R. K.

1945 Bone Implement Burial, Collin County, Texas. Bulletin of the Texas Archeological and Paleontological Society 16:84-89.

Harris, R. K., and Inus Marie Harris

1970 A Bison Kill on Dixon's Branch, Site 27A2-5, Dallas County, Texas. The Record 27(1):1-4.

Harris, R. K., I. M. Harris, and M. P. Miroir

1980 The Atlanta State Park Site in Northeastern Texas. Louisiana Archaeology 6:231-239.

Harris, R. K., and Dee Ann Suhm (editors)

1963 An Appraisal of the Archeological Resources of Forney Reservoir, Collin, Dallas, Kaufman, and Rockwall Counties, Texas. Texas Archeological Salvage Project, The University of Texas at Austin.
Hatfield, Virginia L.

1997 Paleoindian Evidence at the Triple S Ranch Site, Hamilton County, Texas. Current Research in the Pleistocene 14:32-34.

Hays, T. R. (compiler and editor)

1982 Archaeological Investigations at the San Gabriel Reservoir Districts, Central Texas. 3 Vols. Archaeology Program, Institute of Applied Sciences, North Texas State University, Denton.

Hayward, O. T.

1988a The Comanchean Section of the Trinity Shelf, Central Texas. In South-Central Section of the Geological Society of America, Centennial Field Guide Volume 4, edited by O. T. Hayward, pp. 323-328. Geological Society of America, Boulder, Colorado.

1988b Gulfian Rocks, Western Margin of the East Texas Basin. In South-Central Section of the Geological Society of America, Centennial Field Guide Volume 4, edited by O. T. Hayward, pp. 329-334. Geological Society of America, Boulder, Colorado.

Hayward, O. T., Peter M. Allen, and David L. Amsbury

1996 Lampasas Cut Plain: Episodic Development of An Ancient and Complex Regional Landscape, Central Texas. In Guidebook to Upland, Lowland, and In Between-Landscapes in the Lampasas Cut Plain, edited by David L. Carlson, pp. 1-1 through 1-97. Friends of the Pleistocene South-Central Cell 1996 Field Trip. Department of Anthropology, Texas A\&M University, College Station, and Department of Geology, Baylor University, Waco.

Hentz, T. F., and L. F. Brown J r.

1987 Geologic Atlas of Texas, Wichita FallsLawton Sheet. Bureau of Economic Geology, The University of Texas at Austin.

Hester, Thomas R.

1989 Historic Native American Populations. In From the Gulf to the Rio Grande: Human Adaptation in Central, South, and Lower Pecos Texas, by Thomas R. Hester, Stephen L. Black, D. Gentry Steele, Ben W. Olive, Anne A. Fox, Karl J . Reinhard, and Leland C. Bement, pp. 77-84. Research 
Series No. 33. Arkansas Archeological Survey, Fayetteville.

Huebner, J effery A.

1991 Late Prehistoric Bison Populations in Central and South Texas. Plains Anthropologist 36(137):343-358.

Hofman, J ack L.

1989 Prehistoric Culture History-Hunters and Gatherers in the Southern Great Plains. In From Clovis to Comanchero: Archeological Overview of the Southern Great Plains, by J ack L. Hofman, Robert L. Brooks, J oe S. Hays, Douglas W. Owsley, Richard L. J antz, Murray K. Marks, and Mary H. Manhein, pp. 25-60. Research Series No. 35. Arkansas Archeological Survey, Fayetteville.

Hofman, J ack L., Robert L. Brooks, J oe S. Hays, Douglas W. Owsley, Richard L. J antz, Murray K. Marks, and Mary H. Manhein

1989 From Clovis to Comanchero: Archeological Overview of the Southern Great Plains. Research Series No. 35. Arkansas Archeological Survey, Fayetteville.

Hughes, J ack

1942 An Archeological Excavation on the Harrel Site of North Central Texas. Unpublished Master's thesis, Department of Anthropology, The University of Texas at Austin.

J ackson, A. T.

n.d. Exploration of a burial site on Goode Hunt farm in Cass County, Texas. Ms. on file, Texas Archeological Research Laboratory, The University of Texas at Austin.

J elks, Edward B.

1961 Excavations at Texarkana Reservoir, Sulphur River, Texas. River Basin Surveys Papers No. 21, from Bureau of American Ethnology Bulletin 179. U.S. Government Printing Office, Washington, D.C.

1962 The Kyle Site: A Stratified Central Texas Aspect Site in Hill County, Texas. Archeology Series No. 5. Department of Anthropology, The University of Texas at Austin.

1970 Documentary Evidence of Indian Occupation at the Stansbury Site (41-39B1-1), Appendix B. Bulletin of the Texas Archeological Society 41:277-286.
J elks, Edward B. (editor)

1967 The Gilbert Site: A Norteño Focus Site in Northeastern Texas. Bulletin of the Texas Archeological Society 37:1-248.

J ohnson, LeRoy, J r.

1962 The Yarbrough and Miller Sites of Northeastern Texas, with a Preliminary Definition of the La Harpe Aspect. Bulletin of the Texas Archeological Society 32:141284.

J ohnson, LeRoy, and Glenn T. Goode

1994 A New Try at Dating and Characterizing Holocene Climates, as Well as Archeological Periods, on the Eastern Edwards Plateau. Bulletin of the Texas Archeological Society 65:1-51.

J ones, Buddy Calvin

1968 The Kinsloe Focus: A Study of Seven Historic Caddoan Sites in Northeast Texas. Unpublished Master's thesis, University of Oklahoma, Norman.

Kelley, David B. (editor)

1994 The McLelland and J oe Clark Sites: Protohistoric-Historic Caddoan Farmsteads in Southern Bossier Parish, Louisiana. Coastal Environments, Inc., Baton Rouge.

Kier, R. S., L. F. Brown J r., and P. Harwood

1976 Geologic Atlas of Texas, Brownwood Sheet. Bureau of Economic Geology, The University of Texas at Austin.

Kleinbach, Karl, Gemma Mehalchick, James T. Abbott, and J . Michael Quigg

1995 Other Analyses. In NRHP Significance Testing of 57 Prehistoric Archeological Sites on Fort Hood, Texas, Volume II, edited by J ames T. Abbott and Nicholas Trierweiler, pp. 765-842. Research Report No. 34. Archeological Resource Management Series, United States Army, F ort Hood.

Krieger, Alex D.

1946 Culture Complexes and Chronology in Northern Texas with Extension of Puebl oan Dating to the Mississippi Valley. Publication 4640. The University of Texas at Austin.

Krieger, Margery $\mathrm{H}$

1996 Tawakoni Indians. In The New Handbook of Texas, Volume 6, edited by Ron Tyler, p. 213. The Texas State Historical Association, Austin, Texas. 
LBJ School of Public Affairs

1978 Preserving Texas' Natural Heritage. Project Report 31. Natural Heritage Policy Research Project, The University of Texas at Austin.

Lewis, G. A.

1987 The Clement's Brothers' Farm Site 41CS25. Unpublished Master's thesis, Department of Anthropology, The University of Texas at Austin.

Lorrain, Dessamae

1967 The Glass Site. In A Pilot Study of Wichita Indian Archeology and Ethnohistory, edited by Robert E. Bell, Edward B. J elks, and W. W. Newcomb, pp. 24-44. Final Report for National Science Foundation Grant GS-964.

1969 Archaeological Excavations in the Fish Creek Reservoir. Contributions in Anthropology No. 4. Department of Anthropology, Southern Methodist University, Dallas.

Lorrain, Dessamae, and Norma Hoffrichter

1968 The Lower Rockwall Site, Rockwall County, Texas. Archaeological Salvage Project, Southern Methodist University, Dallas.

Lynott, Mark J .

1975 Archaeological Excavations at Lake Lavon, 1974. Contributions in Anthropology No. 16. Department of Anthropology, Southern Methodist University, Dallas.

1977 A Regional Model for Archaeological Research in North Central Texas. Unpublished Ph.D. dissertation, Southern Methodist University, Dallas.

1981 A Model of Prehistoric Adaptation in Northern Texas. Plains Anthropologist 26(92):97-110.

Mallouf, Michael G.

1979 Archeological Investigations at Lake Limestone Research Report 71. Texas Archeological Survey, The University of Texas at Austin.

Mallouf, Robert J .

1976 Archeological Investigations at Proposed Big Pine Lake, 1974-1975, Lamar and Red River Counties, Texas. Archeological Survey Report 18. Texas Historical Commission, Austin.
1981 A Case Study of Plow Damage to Chert Artifacts: The Brooken Creek Cache, Hill County, Texas. Office of the State Archeologist Report 33. Texas Historical Commission, Austin.

Malone, J ames M., and Alton K. Briggs

1970 An Archeological Survey of the Texarkana Reservoir Enlargement Area: Report on the First Season. Archeological Survey Report No. 7. Texas Historical Survey Committee and Texas Water Development Board, Austin.

Martin, Ernest R.

1994 The Dillard Site, a Late Prehistoric Village on the Red River in Cooke County, Texas. Bulletin of the Texas Archeological Society 62:105-200.

Masson, Marilyn A., and Michael B. Collins

1995 The Wilson-Leonard Site (41WM235). Cultural Resource Management News and Views 7(1):6-10. Texas Historical Commission, Austin.

McGowen, J. H., D. E. Owen, M. K. Pieper, and C. A. Shelby

1967 Geologic Atlas of Texas, Sherman Sheet. Bureau of Economic Geology, The University of Texas at Austin.

McGowen, J. H., C. V. Proctor, W. T. Haenggi, D. F. Reaser, and V. E. Barnes

1972 Geologic Atlas of Texas, Dallas Sheet. Bureau of Economic Geology, The University of Texas at Austin.

McGregor, Daniel E., and J ames E. Bruseth (editors) 1987 Hunter-Gatherer Adaptations Along the Prairie Margin: Site Excavations and Synthesis of Prehistoric Archaeology. Richland Creek Technical Series, Vol. III. Archaeology Research Program, Institute for the Study of Earth and Man, Southern Methodist University, Dallas.

McKinney, Wilson W.

1981 Early Holocene Adaptations in Central and Southwestern Texas: The Problem of the Paleoindian-Archaic Transition. Bulletin of the Texas Archeology Society 52:91-120.

Mehalchick, Gemma, Karl Kleinbach, Douglas K. Boyd, Steve A. Tomka, and Karl W. Kibler

1999 National Register Testing of 19 Prehistoric 
Archeological Sites at Fort Hood, Texas: The 1995 Season. Research Report No. 37. Archeological Resource Management Series, United States Army, F ort Hood.

Miroir, M. P., R. King Harris, J ay C. Blaine, and J anson McVay

1975 Bénard de la Harpe and the Nassonite Post. Bulletin of the Texas Archeological Society 44:113-167.

Morgan, Larry W.

1975 An Empirical Analysis of a preNeoAmerican Site in Dallas County, Texas. Unpublished Master's thesis, The University of Texas at Arlington.

Morris, Virginia, and Bill Morris

1970 Excavation of Bison Remains in Northwest Dallas County. The Record 27(1):2-5.

Nelson, Bo, and Timothy K. Perttula

1993 The Z. V. Davis-McPeek Site, an Early Caddoan Mound Site in the Little Cypress Creek Valley, Upshur County, Texas. Notes on Northeast Texas Archaeology 2:50-65.

Newcomb, W. W., J r.

1961 The Indians of Texas: From Prehistoric to Modern Times. The University of Texas Press, Austin.

Newcomb, W. W., and T. N. Campbell

1982 Southern Plains Ethnohistory: A Reexamination of the Escanjaques, Ahijados, and Cuitoas. In Pathways to Plains Prehistory: Anthropological Perspectives of Plains Natives and Their Pasts, edited by Don G. Wyckoff and J ack L. Hofman, pp. 29-43. Oklahoma Anthropological Society Memoir 3 and The Cross Timbers Heritage Association Contributions 1, Duncan, Oklahoma.

Parsons, Mark

1999 Timber Hill. Current Archeology in Texas 1(1):26-27. Texas Historical Commission, Austin.

\section{Perino, Gregory}

1981 Archeological Investigations at the Roden Site (MC-215), McCurtain County, Oklahoma. Potsherd Press Publication No. 1. Museum of the Red River, I dabel, Oklahoma.

1983 Archaeological Research at the Bob Williams Site (41RR16), Red River County, Texas. Potsherd Press, Museum of the Red River, I dabel, Oklahoma.

1994 Archaeological Research at the Rowland Clark Site (41RR77), Red River County, Texas. J ournal of Northeast Texas Archaeology 4:3-42.

1995 The Dan Holdeman Site (41RR11), Red River County, Texas. J ournal of Northeast Texas Archaeol ogy 6:3-65.

Perttula, Timothy K.

1990 Historic Context: The Evolution of Agricultural Societies in Northeast Texas before A.D. 1600. Historic context on file at the Texas Historical Commission, Austin.

1992 "The Caddo Nation": Archaeological and Ethnohistoric Perspectives. The University of Texas Press, Austin.

1994 Caddoan Mound Sites in the Sabine River Basin of Northeast Texas. Caddoan Archeology Newsl etter IV(4):4- 19.

Perttula, Timothy K. (editor)

1999 The Hurricane Hill Site (41HP106): The Archaeology of a Late Archaic/ Early Ceramic and Early-Middle Caddoan Settle ment in Northeast Texas. Special Publication No. 4. Friends of Northeast Texas Archaeology.

Perttula, Timothy K., and J . Brett Cruse

1997 The Caddoan Archaeology of the Sabine River Basin during the Middle Caddoan Period. J ournal of Northeast Texas Archaeology 9:30-37.

Perttula, Timothy K., Hector Neff, Michael D. Glascock, Sue Mulholland, Bo Nelson, Melinda Tate, J ames W. Cogswell, Elizabeth Skokan, and Robert Rogers

1998 Analysis of the Titus Phase Mortuary Assemblage at the Mockingbird Site, "Kahbakayammaahin" (41TT550). Document No. 970849. Espey, Huston and Associates, Inc., Austin.

Perttula, Timothy K., and Bob D. Skiles

1988 41RA65, An Early Ceramic-Early Caddoan Period Site on Garrett Creek, Rains County, Texas. The Record 42(3):69-81.

Perttula, Timothy K., Bob D. Skiles, Michael B. Collins, Margaret C. Trachte, and Fred Valdez J $r$.

1986 "This Everlasting Sand Bed": Cultural 
Resources Investigations at the Texas Big Sandy Project, Wood and Upshur Counties, Texas. Reports of Investigations No. 52. Prewitt and Associates, Inc., Austin.

Peter, Duane E., and Daniel E. McGregor (editors)

1988 Late Holocene Prehistory of the Mountain Creek Drainage J oe Pool Lake Archaeological Project, Vol. I. Archaeology Research Program, Southern Methodist University, Dallas.

Pieper, M. K., C. A. Shelby, W. T. Haenggi, D. E. Owen, and A. C. Wright

1975 Geologic Atlas of Texas, Tyler Sheet. Bureau of Economic Geology, The University of Texas at Austin.

Prewitt, Elton R.

1974 Archeological Investigations at the Loeve Fox Site, Williamson County, Texas. Research Report 49. Texas Archeological Survey, The University of Texas at Austin.

1981 Cultural Chronology in Central Texas. Bulletin of the Texas Archeological Society 52:65-89.

1982 Archeological Investigations at the Loeve Fox, Loeve and Tombstone Bluff Sites in the Granger Lake District of Central Texas. Archaeological Investigations at the San Gabriel Reservoir Districts, Central Texas, Vol. IV. Archaeology Program, Institute of Applied Sciences, North Texas State University, Denton.

1985 From Circleville to Toyah: Comments on Central Texas Chronology. Bulletin of the Texas Archeological Society 54:201-238.

Prewitt, Elton R., and Douglas A. Lawson

1972 An Assessment of the Archeological and Paleontological Resources of Lake Texoma, Texas-Oklahoma. Survey Reports No. 10. Texas Archeological Salvage Project, The University of Texas at Austin.

Prikryl, Daniel

1990 Lower Elm Fork Prehistory: A Redefinition of Cultural Concepts and Chronologies along the Trinity River, NorthCentral Texas. Office of the State Archeologist Report 37. Texas Historical Commission, Austin.

1993 Regional Preservation Plan for Archeological Resources, Prairie-Savanna Arch- eological Region: Introduction. In Archeology in the Eastern Planning Region, Texas: A Planning Document, edited by Nancy Adele Kenmotsu and Timothy K. Perttula, pp. 191-204. Cultural Resource Management Report 3. Department of Antiquities Protection, Texas Historical Commission, Austin.

Prikryl, Daniel J ., and Bonnie C. Yates

1987 Test Excavations at 41CO141, Ray Roberts Reservoir, Cooke County, Texas. Contributions in Archaeology No. 4. Institute of Applied Sciences, North Texas State University, Denton.

Proctor, C. V., J r., T. E. Brown, J. H. McGowen, and N. B. Waechter

1981 Geologic Atlas of Texas, Austin Sheet. Bureau of Economic Geology, The University of Texas at Austin.

Proctor, C. V., J r., J . H. McGowen, and W. T. Haenggi

1970 Geologic Atlas of Texas, Waco Sheet. Bureau of Economic Geology, The University of Texas at Austin.

Redder, Albert J .

1985 Horn Shelter Number 2: The South End, A Preliminary Report. Central Texas Archeol ogist 10:37-65.

Ross, Richard E.

1966 The Upper Rockwall and Glen Hill Sites, Forney Reservoir, Texas. Papers of the Texas Archeological Salvage Project No. 9. The University of Texas at Austin.

Schambach, Frank F.

1982a An Outline of Fourche Maline Culture in Southwest Arkansas. In Arkansas Archeology in Review, edited by Neal L. Trubowitz and Marvin D. J eter, pp. 133197. Research Series No. 15. Arkansas Archeological Survey, Fayetteville.

1982b The Archeology of the Great Bend Region in Arkansas. In Contributions to the Archeology of the Great Bend Region of the Red River Valley, Southwest Arkansas, edited by F. F. Schambach and F. Rackerby, pp. 1-11. Research Series No. 22. Arkansas Archeological Survey, Fayetteville.

Schambach, Frank F., and Ann M. Early

1982 Southwest Arkansas. In A State Plan for the Conservation of Archeological Resources 
in Arkansas, edited by Hester A. Davis, pp. SW1-SW149. Research Series 21. Arkansas Archeological Survey, Fayetteville.

Schambach, Frank F., Neal L. Trubowitz, Frank Rackerby, E. Thomas Hemmings, W. Frederick Limp, and J ohn E. Miller III

1982 Test Excavations at the Cedar Grove Site (3LA97): A Late Caddo Farmstead in the Great Bend Region. In Contributions to the Archeology of the Great Bend Region of the Red River Valley, Southwest Arkansas, edited by Frank F. Schambach and Frank Rackerby, pp. 90-130. Research Series No. 22. Arkansas Archeological Survey, Fayetteville.

Shafer, Harry J .

1963 Test Excavations at the Youngsport Site: A Stratified Terrace Site in Bell County, Texas. Bulletin of the Texas Archeological Society 34:57-81.

Shelby, C. A., M. K. Pieper, D. E. Owen, T. J . Freeman, A. C. Wright, and V. E. Barnes

1979 Geologic Atlas of Texas, Texarkana Sheet. Bureau of Economic Geology, The University of Texas at Austin.

Skinner, S. Alan

1971 Prehistoric Settlement of the De Cordova Bend Reservoir, Central Texas. Bulletin of the Texas Archeol ogical Society 42:149269.

Skinner, S. Alan, M. B. Cliff, L. Baird, A. B. Amerson J r., J . Bennett, A. R. Faust, J . Kaskey, K. Ludden, M. D. Northern, A. Pitchford, J . Raley, D. G. Shaddox, and D. Shanabrook

1982 The Archaeology and History of Lake Ray Roberts, Vol. 1: Cultural Resources Survey. Cultural Resources Report 82-6. Environmental Consultants, Inc., Dallas.

Skinner, S. Alan, R. King Harris, and Keith M. Anderson (editors)

1969 Archaeol ogical Investigations at the Sam Kaufman Site, Red River County, Texas. Contributions in Anthropology No. 5. Southern Methodist University, Dallas.

Smith, J ames E., II

1993 The Vinson Site (41LT1): A Norteño F ocus Indian Village in Limestone County, Texas. Bulletin of the Texas Archeological
Society 64:65-162.

Sorrow, William, Harry J. Shafer, and Richard Ross

1966 The Pecan Springs Site, Bardwell Reservoir, Texas. Papers of the Texas Archeological Salvage Project No. 10. The University of Texas at Austin.

1967 Excavations at Stillhouse Hollow Reservoir. Papers of the Texas Archeological Salvage Project No. 11. The University of Texas at Austin.

Spearing, Darwin

1991 Roadside Geology of Texas. Mountain Press Publishing Company, Missoula, Montana.

Stephenson, Robert L.

1949 Archaeological Survey of Lavon and GarzaLittle Elm Reservoirs: A Preliminary Report. Bulletin of the Texas Archeological and Paleontological Society 20:21-62.

1950a Archeological Survey of Texarkana Reservoir, Bowie and Cass Counties, Texas. River Basin Surveys, Smithsonian Institution, Washington.

1950b Archeological Survey of Garza-Little Elm Reservoir, Denton County, Texas. River Basin Surveys, Austin Office, Smithsonian Institution, Washington.

1952 The Hogge Bridge Site and the Wylie Focus. American Antiquity 17(4):299-312.

1970 Archeological Investigations in the Whitney Reservoir Area, Central Texas. Bulletin of the Texas Archeological Society 41:37-277.

Story, Dee Ann

1965 The Archeology of Cedar Creek Reservoir, Henderson and Kaufman Counties, Texas. Bulletin of the Texas Archeological Society 36:163-257.

1985a Adaptive Strategies of Archaic Cultures of the West Gulf Coastal Plain. In Prehistoric Food Production in North America, edited by Richard I. Ford, pp. 19-56. Anthropological Papers No. 75. Museum of Anthropology, University of Michigan, Ann Arbor.

1985b The Walton Site: An Historic Burial in 
McLennan County, Texas. Central Texas Archeologist 10:66-96.

1990 Cultural History of the Native Americans. In The Archeology and Bioarcheology of the Gulf Coastal Plain, by Dee Ann Story, J anice A. Guy, Barbara A. Burnett, Martha Doty Freeman, J erome C. Rose, D. Gentry Steele, Ben W. Olive, and Karl J . Reinhard, pp. 163-366. Research Series No. 38. Arkansas Archeological Survey, Fayetteville.

Story, Dee Ann, J anice A. Guy, D. Gentry Steele, Barbara A. Burnett, and Martha Doty Freeman

1990 Gulf Coastal Plain Adaptation Types: A Preliminary Statement. In The Archeol ogy and Bioarcheology of the Gulf Coastal Plain, by Dee Ann Story, J anice A. Guy, Barbara A. Burnett, Martha Doty Freeman, J erome C. Rose, D. Gentry Steele, Ben W. Olive, and Karl J. Reinhard, pp. 423-434. Research Series No. 38. Arkansas Archeological Survey, Fayetteville.

Story, Dee Ann, and Harry J . Shafer

19651964 Excavations at Waco Reservoir, McLennan County, Texas: The Baylor and Britton Sites. Miscellaneous Papers No. 6. Texas Archeological Salvage Project, The University of Texas at Austin.

Suhm, Dee Ann

1960 A Review of Central Texas Archeology. Bulletin of the Texas Archeological Society 29:63-107.

Thoms, Alston V. (editor)

1993 The Brazos Valley Slopes Archaeological Project: Cultural Resources Assessments for the Texas A\&M University Animal Science Teaching and Research Complex, Brazos County, Texas. Reports of Investigations No. 14. Archaeological Research Laboratory, Texas A\&M University, College Station.

Thurmond, J . Peter

1981 Archeology of the Cypress Creek Drainage Basin, Northeastern Texas and North-western Louisiana. Unpublished Master's thesis, The University of Texas at Austin.

1985 Late Caddoan Social Group Identifications and Sociopolitical Organization in the
Upper Cypress Basin and Vicinity, Northeastern Texas. Bulletin of the Texas Archeological Society 54:185-200.

1988 Caddoan Archeology, Its Present Status and Future Directions: A Perspective from Northeast Texas. Paper presented at the 30th Caddo Conference, Dallas, Texas.

1990 Archeology of the Cypress Creek Drainage Basin, Northeastern Texas and Northwestern Louisiana. Studies in Archeology 5. Texas Archeological Research Laboratory, The University of Texas at Austin.

Toomey, Rickard S., III, Michael D. Blum, and Salvatore Valastro J $r$.

1993 Late Quaternary Climates and Environments of the Edwards Plateau, Texas. Global and Planetary Change 7:299-320.

Trubowitz, Neal L.

1984 Cedar Grove: An Interdisciplinary Investigation of a Late Caddo Farmstead in the Red River Valley. Research Series No. 23. Arkansas Archeological Survey, Fayetteville.

Tucker, Gordon C.

1994 Archeological Investigations at Site 41BW422. Cultural Resource Manage ment News \& Views 6(1):6.

Turner, Robert L., J r.

1978 The Tuck Carpenter Site and Its Relation to Other Sites within the Titus Focus. Bulletin of the Texas Archeological Society 49:1-110.

1992 Prehistoric Mortuary Remains at the Tuck Carpenter Site, Camp County, Texas. Studies in Archeology 10. Texas Archeological Research Laboratory, The University of Texas at Austin.

Waters, M. R., and L. C. Nordt

1995 Late Quaternary Floodplain History of the Brazos River in East-Central Texas. Quaternary Research 43:311-319.

Watt, Frank $\mathrm{H}$.

1953 Pottery Diffusions of the Central Brazos Valley. Central Texas Archeologist 6:5785.

1978 Radiocarbon Chronology of Sites in the Central Brazos Valley. Bulletin of the 
Texas Archeological Soci ety 49:111-138.

Webb, Clarence $\mathrm{H}$.

1959 The Belcher Mound: A Stratified Caddoan Site in Caddo Parish, Louisiana. Memoirs of the Society for American Archaeology No. 16, Salt Lake City, Utah.

1982 The Bellevue Focus: A MarksvilleTroyville Manifestation in Northwestern Louisiana. In The Troyville-Baytown Period in Lower Mississippi Valley Prehis-tory: A Memorial to Robert Stuart Neitzel, edited by J. L. Gibson. Louisiana Archaeology 9:251-274.

Webb, Clarence H., Forrest B. Murphy, Wesley G. Ellis, and $\mathrm{H}$. Roland Green

1969 The Resch Site, 41HS16, Harrison County, Texas. Bulletin of the Texas Archeological Society 40:3-106.

Webb, Clarence H., J oel L. Shiner, and E. Wayne Roberts

1971 The J ohn Pearce Site (16CD56): A San Patrice Site in Caddo Parish, Louisiana. Bulletin of the Texas Archeological Society 42:1-49.

Wedel, M. M.

1978 La Harpe's 1719 Post on Red River and Nearby Caddo Settlements. Bulletin 30. The Texas Memorial Museum, The University of Texas at Austin.

Weir, Frank A.

1976 The Central Texas Archaic. Unpublished Ph.D. dissertation, Department of Anthropology, Washington State University, Pullman.
Willey, Gordon R., and Philip Phillips

1958 Method and Theory in American Archaeology. University of Chicago Press, Chicago.

Wilson, Lester

1946 Problematical Pits on East Fork. The Record 5(2):11-12.

Woodall, J . Ned

1967a The Coyote Site. In A Pilot Study of Wichita Indian Archeology and Ethnohistory, edited by Robert E. Bell, Edward B. J elks, and W. W. Newcomb, pp. 15-23. Final Report for National Science Found-ation Grant GS-964.

1967b The Upper Tucker Site. In A Pilot Study of Wichita Indian Archeology and Ethnohistory, edited by Robert E. Bell, Edward B. J elks, and W. W. Newcomb, pp. 3-14. Final Report for National Science Foundation Grant GS-964.

Yedlowski, J oseph L., Kevin J . Shaunessy, David H. J urney, and J . M. Adovasio

1998 Archaeol ogical Investigations in Support of the Superconducting Super Collider, Ellis County, Texas. Archaeology Research Program, Mercyhurst College, Erie.

Young, Bill, and Michael B. Collins

1989 A Cache of Blades with Clovis Affinities from Northeastern Texas. Current Research in the Pleistocene 6:26-28.

Young, Wayne C.

1981 Test Excavations in the Tankersl ey Creek Site: A Multicomponent Campsite in Titus County, Texas. State Department of Highways and Public Transportation, Austin. 
APPE NDIX A: Glossary of Technical Terms 
Adze: Tool whose cutting edge is at a right angle to the handle and that is used in working wood.

Arrow point: Point used to tip an arrow, which is propelled by a bow.

Biface: Piece of conchoidally fracturing stone that has had flakes removed from both faces to create a tool.

Burin: Chisel-like tool presumed to have been used in working bone, antler, and wood.

Dart point: Point used to tip a throwing spear or dart, which is propelled by an atlatl.

Debitage: Debris generated by the removal through percussion/pressure of flakes, chips, and chunks to make stone tools.

Fill section: Introduced fill used to elevate the approaches to a bridge above the surrounding terrain.

Flake: Generally thin piece of conchoidally fracturing stone with a positive bulb of percussion showing that it was removed from the parent piece by percussion/pressure.

Gouge: Generally thick, bifacially modified tool presumed to have been used like an adze.

Grog: Crushed fired clay added as temper to clay used in making ceramic vessels.

Impact Evaluation: Onsite inspection documenting existing impacts or other conditions that may preclude the presence of intact archeological deposits within the project area for a proposed Transportation Activity.

Mano: Handheld stone used, usually with a metate, to grind plant parts such as seeds.

Megafauna: Very large animal.

Metate: Anvil of stone used, usually with a mano, to grind plant parts such as seeds.

Midden: Accumulation of occupational debris, particularly organic remains.

Projectile point: I nclusive term for arrow and dart points.

Scraper: Tool with generally thick, unifacially modified edges used to work hides, bone, and wood.

Sherd: A piece of broken pottery.

Survey: Fieldwork to locate archeological remains within the project area for a proposed Transportation Activity, including on-foot examination of the surface, shovel testing, and trenching by mechanical means where appropriate.

Survey with Geoarcheological Evaluation: Fieldwork to locate archeological remains within the project area for a proposed Transportation Activity, including examination and recording of trench walls or other exposures by a geomorphologist, quaternary geologist, physical geographer, soil scientist, or archeologist with the formal training and experience to apply the principles of geology to the evaluation of the pedological, stratigraphic, geomorphic, anthrogenic, and other 
conditions affecting the physical integrity of archeological deposits and the interpretation of archeological materials.

Temper: Nonplastic materials added to clay to decrease the risk of cracking when firing ceramic vessels.

Transportation Activity: any proposed project involving the development, design, construction, or maintenance of the state's intermodal transportation system. 
APPENDIX B: Letters and Letter Reports for I mpact

Evaluations and Surveys 
These reports are on the included CD-ROM, excluding reports for Work Orders 16 and 30. Work Order 16 was a Quality Control debriefing with TxDOT, whereas Work Order 30 was the order to produce this report. Authors for the reports include Ross C. Fields, E. Frances Gadus, Amy M. Holmes, J ennifer K. McWilliams, John W. Arnn III, Paul Maslyk, Karl W. Kibler, Gemma Mehalchick, and Lee Nordt. 